\title{
STATYSTYCZNA OCENA ZNACZENIA SEKTORA USKUG W GOSPODARCE POLSKI
}





\section{Agata Szczukocka}

\section{STATYSTYCZNA OCENA \\ ZNACZENIA SEKTORA USKUG \\ W GOSPODARCE POLSKI}

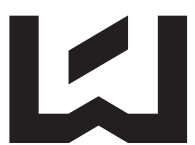

WYDAWNICTWO

UNIWERSYTETU

ŁÓDZKIEGO

ŁóDŹ 2013 
Agata Szczukocka - Katedra Metod Statystycznych, Instytut Statystyki i Demografii Wydział Ekonomiczno-Socjologiczny, Uniwersytet Łódzki

90-214 Łódź, ul. Rewolucji 1905 r. nr 41

RECENZENT

Piotr Niedzielski

\title{
REDAKTOR WYDAWNICTWA UŁ
}

Ewa Siwińska

\section{SKŁAD KOMPUTEROWY \\ Barbara Lebioda}

\section{PROJEKT OKŁADKI}

Joanna Skopińska

Wydrukowano z gotowych materiałów dostarczonych do Wydawnictwa UŁ

C Copyright by Uniwersytet Łódzki, Łódź 2013

\author{
Wydane przez Wydawnictwo Uniwersytetu Łódzkiego \\ Wydanie I. W.06226.13.0.H \\ ISBN (wersja drukowana) 978-83-7525-886-8 \\ ISBN (ebook) 978-83-7969-308-5
}
Wydawnictwo Uniwersytetu Łódzkiego
90-131 Łódź, ul. Lindleya 8
www.wydawnictwo.uni.lodz.pl
e-mail: ksiegarnia@uni.lodz.pl
tel. (42) 66558 63, faks (42) 6655862




\section{Spis treści}

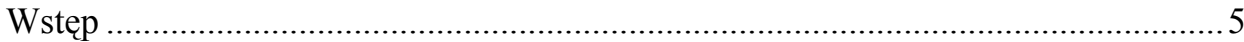

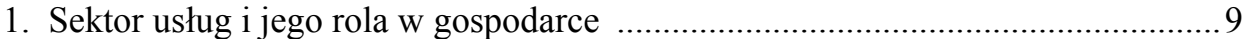

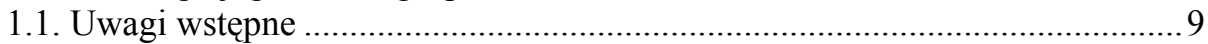

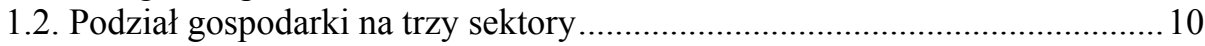

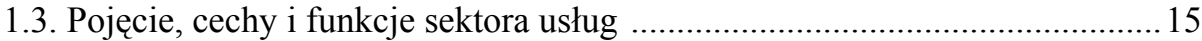

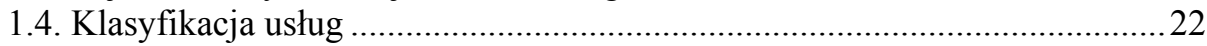

1.5. Tendencje rozwojowe sektora usług $\mathrm{i}$ ich determinanty $\mathrm{w}$ świetle teorii

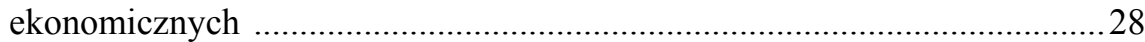

1.6. Zmiany koniunktury gospodarczej a sektor usług ...........................................35

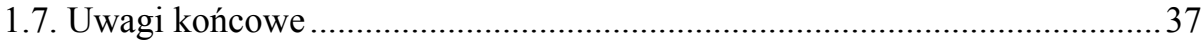

2. Metody statystyczne stosowane $\mathrm{w}$ analizie rozwoju usług ..................................39

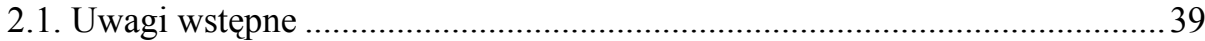

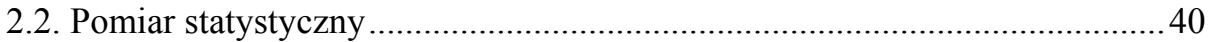

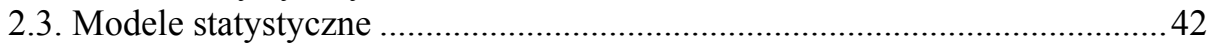

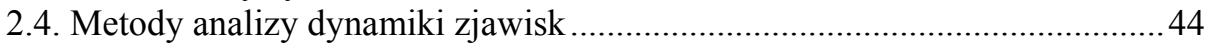

2.5. Wybrane miary zjawisk ekonomicznych .....................................................47

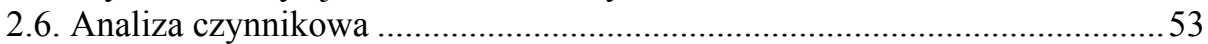

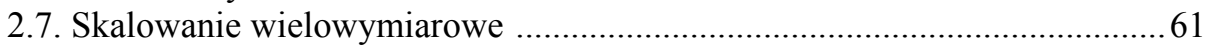

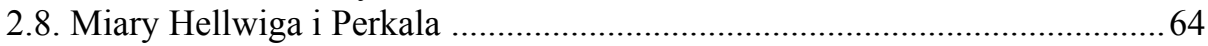

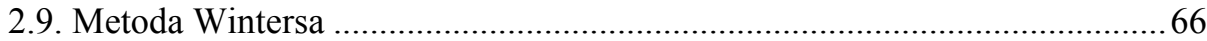

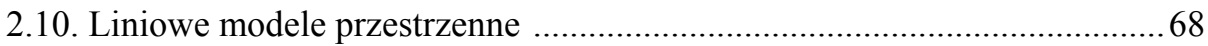

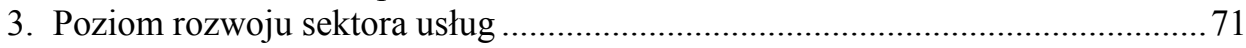

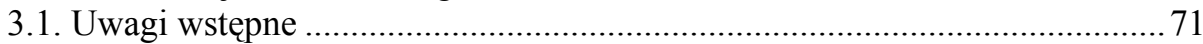

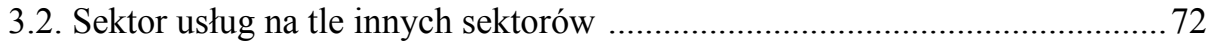

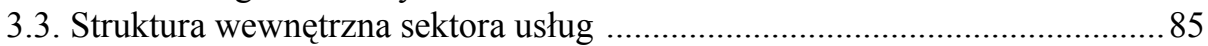

3.4. Charakterystyka sektora usług oparta na analizie czynnikowej ....................93

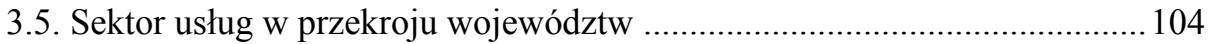

3.6. Rozwój sektora usług w Polsce i innych krajach Unii Europejskiej ...........121

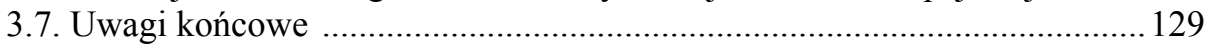

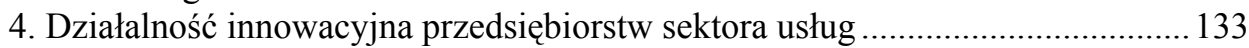

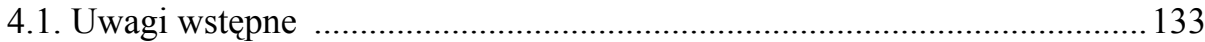

4.2. Pojęcie i specyfika innowacyjności w sektorze usług ..................................133

4.3. Innowacja jako element przewagi konkurencyjnej ...................................... 139

4.4. Poziom i kierunki rozwoju innowacyjności w sektorze usług ...................... 141

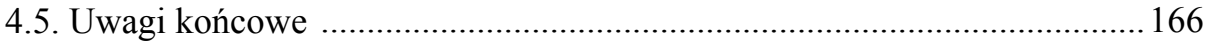


5. Prognozowanie udziału sektora usług w gospodarce ........................................ 169

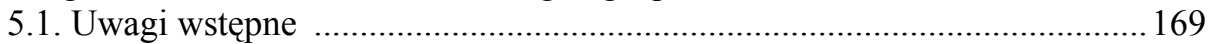

5.2. Prognoza PKB według sektorów gospodarki .......................................... 171

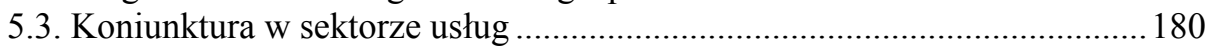

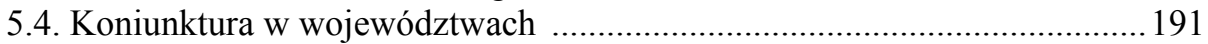

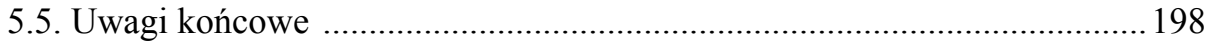

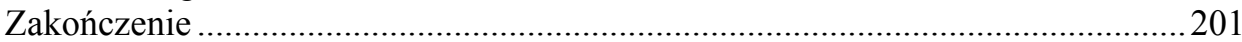

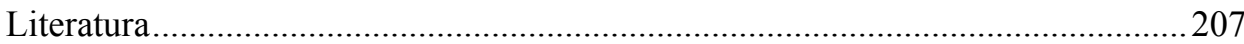

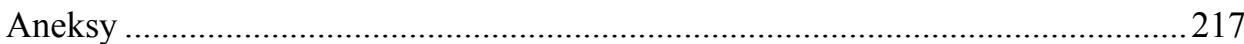

Aneks 1. Wartość dodana brutto w sektorze usług według sekcji w latach

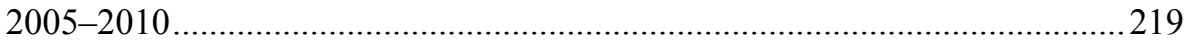

Aneks 2. Struktura pracujących w usługach według sekcji w latach $2005-2010 \ldots 220$

Aneks 3. Nakłady na działalność innowacyjną w przedsiębiorstwach przemysłowych

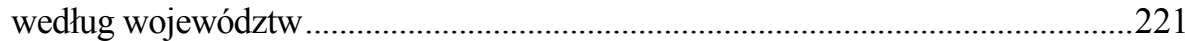

Aneks 4. Dynamika nakładów na działalność innowacyjną w przedsiębiorstwach z sektora usług według rodzajów działalności innowacyjnej oraz działów PKD

Aneks 5. Udział nakładów na działalność innowacyjną w sektorze usług według rodzajów działalności innowacyjnej oraz działów PKD w 2008 r. .....224

Aneks 6. Udział nakładów na działalność innowacyjną w sektorze usług według rodzajów działalności innowacyjnej oraz działów PKD w 2009 r. .....226

Aneks 7. Udział nakładów na działalność innowacyjną w sektorze usług według rodzajów działalności innowacyjnej oraz działów PKD w 2010 r. .....228

Aneks 8. Ankieta koniunktury gospodarczej - GUS ……....................................2230

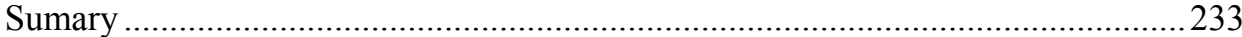




\section{WSTĘP}

Sektor usług ulega wielu przeobrażeniom, a pod wpływem sygnałów płynących z rynku nadal dokonują się w nim zmiany. Zmienia się charakter usług, powstają nowe rodzaje usług między innymi oparte na wysokich technologiach, ale wiele z nich nie ma miejsca bytu. Usługi odgrywają coraz większą rolę $\mathrm{w}$ rozwoju społeczno-gospodarczym. Stanowią dział gospodarki, którego na co dzień w pełni nie doceniamy, ale ten dział zapewnia nam odpowiedni standard życia. Ocena rozwoju rynku usług w Polsce jest zjawiskiem złożonym, na które wpływa wiele różnorodnych czynników, a jednocześnie zależy od zadań każdej jednostki terytorialnej. Badania rozwoju sektora usług wymagają dwukierunkowego podejścia, tzn. analizy zmian znaczenia sektora usług rozumianego jako element trójsektorowej struktury gospodarczej i jego wewnętrznych zmian. Do oceny stopnia rozwoju gospodarki przede wszystkim wykorzystuje się analizy struktur zatrudnienia i wartości dodanej brutto. Analizę zmian strukturalnych można pogłębić, stosując odpowiednie metody ilościowe, które odzwierciedlałyby istotne zmiany dla tendencji rozwojowych sektora usług. Porównanie struktur zatrudnienia i wielkości wartości dodanej brutto w trzech sektorach gospodarki, na tle różnych krajów umożliwia dokonanie oceny stopnia rozwoju sektora usług w Polsce. Pozwala również na określenie dystansu dzielącego słabsze gospodarki od gospodarek państw najbardziej zaawansowanych w rozwoju usług. Rozwój sektora usług oznacza wzrastający jego udział w strukturze zatrudnienia, wartości dodanej i liczbie podmiotów gospodarczych.

$\mathrm{W}$ pracy zaprezentowano zmiany zachodzace $\mathrm{w}$ sektorze usług $\mathrm{w}$ latach 1994-2011 w Polsce na tle pozostałych sektorów. Badania skoncentrowano na trzech problemach badawczych:

1) określeniu roli sektora usług poprzez analizę jego wpływu na proces rozwoju społeczno-gospodarczego,

2) determinantach aktywności innowacyjnej w sektorze usług,

3) wpływie wahań koniunktury na sektor usług.

Wiele publikacji jest poświęconych szeroko rozumianym usługom (por. Daszkowska 1998; Kłosiński 2002, 2009; Niedzielski 2008; Rogoziński 2000; Flejterski 2005; Kłosiński 2011 i inni). W badaniach tych niewiele uwagi poświęcono sektorowi usług w ujęciu regionalnym.

Celem rozprawy jest przedstawienie przestrzennego zróżnicowania poziomu rozwoju usług w Polsce oraz określenie kierunków zachodzących zmian tego sektora. 
Aby zrealizować tak sformułowany cel głównego pracy, przyjęto następujące cele szczegółowe:

- zbadanie, czy zachodzące zmiany w strukturze gospodarki są zgodne z prawidłowościami rozwoju społeczno-gospodarczego;

- ocena za pomocą metod statystycznych wpływu najbardziej istotnych zmiennych na rozwój sektora usług;

- określenie, czy dokonujące się zmiany gospodarcze zmniejszają dystans pomiędzy rozwojem sektora usług w Polsce a pozostałymi państwami Unii Europejskiej;

- analiza wpływu innowacyjności na wzrost i rozwój przedsiębiorstw usługowych;

- charakterystyka koniunktury w sektorze usług.

$\mathrm{Na}$ podstawie analizy wyników wielu badań, w tym badań własnych (por. Szczukocka 2011a, 2011b, 2012), sformułowano hipotezę, iż sektor usług stymuluje rozwój gospodarki, a jego kondycja stanowi o dynamice rozwoju społeczno-gospodarczego poszczególnych jednostek terytorialnych.

Weryfikacji poddano także następujące hipotezy szczegółowe:

- w gospodarce trójsektorowej sektor usług ma charakter dominujący;

- wzrasta podobieństwo w trójsektorowych strukturach pracujących i w tworzeniu wartości dodanej brutto pomiędzy Polską i krajami Unii Europejskiej;

- występuje zróżnicowanie w strukturze pracujących i wartości dodanej brutto w układzie województw;

- innowacyjność jest podstawowym czynnikiem sprzyjającym rozwojowi sektora usług, a województwa o najwyższym poziomie rozwoju społecznogospodarczego tworzą rejony o najwyższej innowacyjności usług;

- województwa o najwyższym poziomie PKB charakteryzują się najwyższym poziomem rozwoju usług;

- sektor usług jest odporny na wahania koniunktury.

Prezentację zmian zachodzących w polskim sektorze usług w latach 19942011 poprzedzono ogólną charakterystyką sektora usług. Ocena sektora usług we współczesnej gospodarce wymaga szerokiego spojrzenia na problem zarówno od strony teorii, jak i aktualnych tendencji, zachodzących na rynku globalnym. Do analiz zachodzących zmian w sektorze usług wykorzystano podstawowe wskaźniki makroekonomiczne, ze szczególnym uwzględnieniem udziału sektora usług w strukturze wartości dodanej brutto oraz pracujących.

Podczas analizy danych niejednokrotnie napotykano na bariery związane z ich porównywalnością. Istotną rolę odegrała tu reforma administracyjna z 1999 r., ustanawiająca 16 województw. Celem reformy było utworzenie dużych regionów, które mogłyby konkurować z innymi regionami po wstąpieniu do Unii Europejskiej. Zmiana liczby województw z 49 na 16 spowodowała brak możliwości porównawczych rozwoju województw z przed i po wprowadzeniu refor- 
my administracyjnej. Pewnym ograniczeniem była także zmiana PKD 2004 na PKD 2007. Informacje publikowane w układzie PKD 2007, dotyczące $\mathrm{m}$. in. sekcji, działów i grup, stały się nieporównywalne z grupowaniami PKD 2007. Kolejną barierą był brak danych na temat produktu krajowego brutto i wartości dodanej, które są publikowane z dwuletnim opóźnieniem. Wszystko to sprawiło, że w pracy koncentrowano się na różnych okresach badawczych. Większość danych, na których się opierano, pochodzi z zasobów Głównego Urzędu Statystycznego (GUS). Dane na temat pracujących ogółem oraz w podziale na trzy sektory, dla poszczególnych województw pochodzą z Roczników Statystycznych, podobnie dane na temat wartości dodanej brutto oraz podmiotów gospodarczych. Część danych została także zaczerpnięta z Banku Danych Lokalnych GUS. Przy danych na temat wskaźników koniunktury korzystano z pomocy Biura Inwestycji i Cykli Koniunkturalnych (BIEC). Pomocne okazały się również dane publikowane przez Instytut Badań nad Gospodarka Rynkową (IBnGR) oraz Instytut Badań Rynku Konsumpcji i Koniunktur (IBRKiK). Wiele informacji zostało pozyskanych z bazy danych Ministerstwa Pracy i Polityki Społecznej oraz Polskiej Agencji Rozwoju Przedsiębiorczości (PARP). Uzupełnieniem bazy danych były badania przeprowadzone przez autorkę dotyczące między innymi usług elektronicznych. W pracy zawarto liczne poglądy dotyczące rozwoju sektora usług oparte na pogłębionych studiach literaturowych, obejmujących zarówno polskie, jak i zagraniczne piśmiennictwo.

W pracy ze względu na wielowymiarowość podejmowanej problematyki, do oceny rynku usług $\mathrm{w}$ Polsce zostały wykorzystane różne metody badawcze. Oparto się zarówno na metodach sprawdzonych, znanych z literatury, jak i propozycjach własnych autorki, polegających na zastosowaniu wybranych metod statystycznych lub ich modyfikacji.

Praca ma charakter teoretyczno-empiryczny. Rozważania teoretyczne oparto na krajowej i zagranicznej literaturze przedmiotu. W części empirycznej pracy analizy prowadzono w układzie międzynarodowym, krajowym oraz regionalnym.

Praca składa się z pięciu rozdziałów. Rozdział pierwszy obejmuje pojęcie usług, jego ewolucję i proces kształtowania się sektora usług ze względu na trójsektorowy podział gospodarki. Przedstawione zostały charakterystyczne cechy usług, klasyfikacja i pełnione przez ten sektor funkcje w gospodarce. Opierając się na różnych teoriach ekonomicznych, wskazano na tendencje rozwojowe sektora usług.

Złożoność procesu rozwoju oraz różnorodność usług, na który wpływa wiele zmiennych, powoduja, że przeprowadzenie obiektywnej oceny rynku usług w Polsce wymaga doboru odpowiednich metod statystycznych. Do realizacji tego celu w rozdziale drugim starano się wykorzystać różne metody statystyczne, między innymi: miary położenia, zróżnicowania, dynamiki, analizę czynnikowa, skalowanie wielowymiarowe, miarę rozwoju Perkala i Hellwiga oraz modele przestrzenne. 
W trzecim rozdziale przedstawiono proces rozwoju sektora usług w Polsce z uwzględnieniem innych sektorów gospodarki oraz na tle krajów Unii Europejskiej. W rozdziale tym przeprowadzono analizę zachodzących zmian w liczbie pracujących, wartości dodanej brutto oraz w liczbie podmiotów gospodarczych w ujęciu sektorowym. Dokonano także analizy porównawczej stopnia zróżnicowania rozwoju sektora usług w oparciu o zaproponowane wskaźniki w układzie województw z uwzględnieniem poszczególnych sekcji usługowych.

Rozważania w rozdziale czwartym koncentrują się na działalności innowacyjnej przedsiębiorstw usługowych. W rozdziale tym poddano analizie innowacyjność jako determinantę rozwoju sektora usług oraz element przewagi konkurencyjnej. Dokonano oceny i wskazano na kierunki rozwoju innowacyjności w sektorze usług.

W rozdziale piątym na podstawie aktualnych wyników badań dokonano diagnozy i podjęto próbę prognozowania koniunktury w polskiej gospodarce jako całości, w sektorze usług według województw. Ranga podjętego problemu wynika $\mathrm{z}$ istotnych przesłanek, świadczących o ułatwianiu w podejmowania skomplikowanych decyzji gospodarczych.

Monitorowanie procesu rozwoju sektora usług poprzez przeprowadzanie badań stwarza możliwości podjęcia odpowiedniej polityki regionalnej, mającej na celu zmniejszenie różnic pojawiających się w poszczególnych województwach czy państwach. Oceniając rozwój sektora usług, niejednokrotnie odnoszono się do Strategii Rozwoju Kraju na lata 2007-2015, uwzględniono wartości wskaźników monitorujących strategię aktualizowanych przez GUS, dostępnych na stronie internetowej GUS i Ministerstwa Rozwoju Regionalnego.

Analiza wyników badań na temat rynku usług oraz dokumentów pozwala określić dalszy rozwój sektora usług w kierunku usług biznesowych, nowych technologii, usług związanych z edukacją, ochroną zdrowia i czasem wolnym.

Wybór tematu był podyktowany jego aktualnością i znaczeniem sektora usług w procesach społeczno-gospodarczych. Sektor usług w coraz większym stopniu oddziałuje na produkcję, wymianę i konsumpcję. Obserwujemy nasilający się proces przenikania produktów materialnych i usługowych. Zauważalny jest także wpływ sektora usługowego na wzrost inwestycji, innowacyjności i poprawę konkurencyjności polskiej gospodarki. Badanie zjawisk i prawidłowości wyjaśniających rosnące znaczenie tego sektora oraz fakt jego niedoceniania stał się przesłanką do podjęcia różnego rodzaju badań. W szczególności wypełniona została luka dotycząca znaczenia sektora usług w przekroju województw.

W tym miejscu pragnę podziękować dr. hab. prof. US Piotrowi Niedzielskiemu za cenne uwagi i sugestie, które pozwoliły przygotować końcową wersję niniejszej pracy. 


\section{SEKTOR USŁUG I JEGO ROLA W GOSPODARCE}

\subsection{Uwagi wstępne}

Wiele prac zostało poświęconych trójsektorowemu podziałowi gospodarki i coraz większej roli sektora usług (por. np. Clark 1951, Fisher 1935, Fourastié 1954). Polska gospodarka, pokonując deformacje strukturalne odziedziczone po poprzednim systemie, podąża $\mathrm{w}$ kierunku zmian strukturalnych określonych przez państwa wysoko rozwinięte. Dokonujące się zmiany strukturalne są zjawiskiem złożonym, dlatego słuszne wydaje się przybliżenie pojęcia struktury. $\mathrm{W}$ analizach ekonomicznych wykorzystujących pojęcie struktury zwraca się uwagę na dwa istotne elementy tego pojęcia, tzn. element proporcji i stosunków oraz element trwałości (por. Kwiatkowski 1980, s. 52-55). „Struktura oznacza proporcje i stosunki między wyodrębnionymi częściami badanej całości (układu). Analizy struktur wymagają więc jasnego określenia badanej całości oraz poszczególnych elementów składowych tej całości. Jest istotne, aby badana całość była dzielona na elementy składowe zgodnie z zasadami podziału logicznego, a zwłaszcza zasadą całkowitości (suma elementów składowych daje badaną całość ) oraz zasadą rozłączności (elementy składowe nie powinny nachodzić na siebie)" (Kwiatkowska 2007, s. 16). Natomiast przez strukturę gospodarczą rozumie się proporcje i relacje między wyodrębnionymi elementami gospodarki (por. Kwiatkowska 2000, s. 99). Uwzględniając wymienione zasady, można interpretować strukturę jako stosunki między poszczególnymi elementami składowymi badanej całości a także stosunki między tymi elementami a badaną całością.

Przedmiotem analiz opartych na koncepcji podziału gospodarki na trzy sektory jest struktura gospodarki i zmian strukturalnych, jakie w niej zachodzą. Określenie zachodzących zmian (tendencji) w przemianach gospodarczych może być wyrazem rozwoju gospodarczego, natomiast brak odpowiednich zmian w strukturze gospodarki może być uznawany za przyczynę słabego rozwoju ekonomicznego kraju.

Istotną rzeczą jest także ocena bieżącej struktury gospodarki i jej wpływ na dalszy rozwój gospodarki. W przeprowadzonych rozważaniach głównie skoncentrowano się na porównaniach zmianach strukturalnych zachodzących w trzech sektorach gospodarki, ze szczególnym uwzględnieniem sektora usług. Analizy zmian strukturalnych pozwalają na lepsze poznanie zachodzących pro- 
cesów gospodarczych i lepsze zrozumienie ich istoty. Poprzez wskazanie, które elementy strukturalne rozwijają się szybciej, a które wolniej, przeprowadzane analizy dają możliwość formułowania wniosków na temat tempa zachodzących zmian. W przypadku niewystarczających zmian wskazana jest polityka strukturalna państwa, która polega na przyspieszeniu rozwoju niektórych elementów strukturalnych gospodarki oraz spowolnienie innych.

Poprzez wielość funkcji, jakie pełnią usługi, starano się przedstawić rolę sektora usług w gospodarce. Opierając się na zachodzących w gospodarce zmianach strukturalnych, wskazano na determinanty rozwoju sektora usług.

\subsection{Podział gospodarki na trzy sektory}

Genezy teorii trzech sektorów należy doszukiwać się w poglądach merkantylistów, którzy twierdzili, że w procesie pomnażania bogactwa nie wszystkie dziedziny gospodarki odgrywają taką samą rolę (por. Merkantylizm... 1958). Merkantyliści uważali, że w procesie pomnażania bogactwa kraju nie wszystkie dziedziny gospodarki odgrywają jednakową rolę, szczególne znaczenie przypisywali rozwojowi przemysłu i handlu, znacznie mniejsze rozwojowi rolnictwa (Kwiatkowski 1980). Konieczność rozwoju przemysłu tłumaczyli szybszym pomnażaniem bogactwa kraju. Zwracali uwagę na większą efektywność pracy w przemyśle niż w rolnictwie, wskazując na naturalne czynniki ograniczające rozwój rolnictwa. Merkantyliści podkreślali także większą opłacalność produkcji przemysłowej od rolnej, twierdząc, że w przemyśle wzrost rozmiarów produkcji jest związany ze spadkiem kosztów produkcji, czego nie obserwujemy w rolnictwie. Istotne znaczenie handlu, którego merkantyliści podkreślali w procesie pomnażania bogactwa kraju, wynikało zaś z dostrzegania sensu pomnażania produkcji w rozwoju wymiany. Analiza ich poglądów pozwala stwierdzić, że zauważali oni pewne prawidłowości w rozwoju trzech działów gospodarki, rolnictwa, przemysłu i handlu, w procesie wzrostu bogactwa. Problemami teorii trzech sektorów zajmowali się także Petty (Merkantylizm... 1958), Smith (1954), Surowiecki (1957), Skarbek (1931) oraz List (1922).

Zdaniem Petty`ego o bogactwie kraju decyduje ilość, jakość oraz rozmieszczenie pracy w poszczególnych dziedzinach gospodarki. Zwracał uwagę na rozwój przemysłu, handlu i transportu, twierdząc, że państwa rolnicze osiagają niższy poziom bogactwa niż te, w których dominuje dobrze rozwinięty przemysł, transport $\mathrm{i}$ handel. W związku z takim spostrzeżeniem Petty postulował rozwój tych dziedzin poprzez wzrost zatrudnienia w usługach.

Według Smitha dla pomnażania bogactwa kraju zasadnicze znaczenie mają nie tylko rozmiary akumulacji kapitału, ale także jej kierunki. Sądził, że w początkowym okresie rozwoju większa część kapitału jest kierowana do rolnictwa, 
a następnie w miarę dalszego rozwoju do przemysłu i handlu. Wzrost znaczenia przemysłu i handlu w rozumieniu Smitha był rzeczą naturalną, prawidłowością właściwą dla procesu rozwoju gospodarczego.

Problemy rozwoju gospodarczego i zmian znaczenia poszczególnych działów w gospodarce zaobserwowali także polscy ekonomiści: Skarbek i Surowiecki (Flejterski, Panasiuk, Perenc, Rosa 2008). Zgodnie twierdzili, że podstawą dalszego rozwoju gospodarczego jest przekształcenie gospodarki poprzez położenie głównego nacisku na rozwój przemysłu i handlu. Surowiecki większy nacisk kładł na rozwój przemysłu, który według niego był decydującym elementem rozwoju gospodarczego. Skarbek sądził, że rozwój gospodarczy poszczególnych działów gospodarki ma charakter naturalny, wykluczał ingerencję państwa, co nie było i nie jest właściwe w przypadku państw słabo rozwiniętych.

Zainteresowanie problemami rozwoju gospodarczego obserwujemy także wśród ekonomistów niemieckich zwłaszcza u Lista. Na szczególną uwagę zasługuje stworzona przez Lista koncepcja stadiów rozwojowych, według której wyróżniał (Kwiatkowski 1980):

- stan dzikości,

- stadium pasterstwa,

- stadium rolnicze,

- stadium rolniczo-przemysłowe,

- stadium rolniczo-przemysłowo-handlowe.

List uważał, że prawidłowością rozwoju gospodarczego jest przechodzenie od niższych do wyższych stadiów rozwojowych, poza tym wskazywał na przesuwanie się centrum działalności gospodarczej od rolnictwa do przemysłu, a następnie do handlu. Podkreślał także znaczenie przemysłu dla rozwoju rolnictwa oraz proces przechodzenia siły roboczej z rolnictwa do przemysłu.

Od czasów Lista przez pewien okres obserwujemy brak większego zainteresowania problemami rozwoju poszczególnych działów gospodarki. Problemem tym dopiero na początku XX w. zainteresował się angielski ekonomista Hobson (1927). Hobson zauważył tendencję spadku znaczenia rolnictwa i wzrost znaczenia produkcji niematerialnej w gospodarce, nie stworzył jednak szerszej koncepcji przemian w znaczeniu poszczególnych działów w gospodarce.

Rozwój sektora usług kojarzony jest przede wszystkim z nazwiskami trzech ekonomistów: Fishera (1933, 1935), Clarka (1951) oraz Fourastiégo (1954), których uznaje się za twórców tzw. teorii trzech sektorów (por. Kwiatkowski 1980, s. 59 i dalsze). Koncepcja trójsektorowej struktury gospodarczej rozwinięta została w latach trzydziestych XX w. Jej twórcy poddawali analizie prawidłowości i czynniki rozwoju poszczególnych sektorów gospodarki, badali strukturę gospodarczą na podstawie relacji pomiędzy poszczególnymi sektorami gospodarki a całą gospodarką. Prowadzili badania dotyczące proporcji międzysektorowych w zakresie zatrudnienia oraz w zakresie produkcji. 
Na uwagę zasługuje fakt, że Fisher, Clark i Fourastié tworzyli w różnych warunkach społeczno-gospodarczych. Fisher na początku lat trzydziestych poszukiwał przyczyn kryzysów gospodarczych. Sądził, że uchwycenie zachodzących prawidłowości pozwoli stworzyć podstawy zapobiegania kryzysom. Fisher był przekonany, że ze względu na zmieniającą się strukturę spożycia i popytu zachodzi potrzeba ciągłego dostosowywania się produkcji, co z kolei jest uwarunkowane przepływem zasobów siły roboczej do nowo powstających dziedzin gospodarki. Uważał on, że w sytuacji braku takich przepływów lub też słabej ich efektywności w gospodarce pojawią się kryzysy, którym starał się zapobiec poprzez określanie metod służących im zapobieganiu, wyznaczając dotychczasowe i przyszłe kierunki przepływu czynników produkcji. W związku z tym wyodrębnił $\mathrm{w}$ gospodarce sektor rolniczy, przemysłowy i usługowy oraz wysunął tezę o spadku znaczenia sektora rolniczego i wzroście sektora usługowego. W przypadku sektora przemysłowego w początkowej fazie postępu ekonomicznego podkreślał wzrost jego znaczenia, a następnie spadek na korzyść sektora usługowego. W swoich badaniach dążył do określenia charakteru zmian w znaczeniu poszczególnych sektorów, których wymaga realizacja postępu ekonomicznego. Do sektora usług zaliczał gałęzie wytwarzające produkty o dochodowej elastyczności popytu powyżej 1 . Głębokie przekonanie o wzajemnych uwarunkowaniach postępu ekonomicznego i przemianach w znaczeniu trzech sektorów stanowiło istotne osiagnięcie Fishera w teorii trzech sektorów.

Clark w odróżnieniu od Fishera nie podejmował prób wyjaśnienia przyczyn kryzysów gospodarczych, ponieważ tworzył w okresie ożywienia gospodarczego. Swą uwagę koncentrował na rozważaniach, dotyczących kwestii różnic w poziomie i tempie rozwoju poszczególnych krajów. Podobnie zaś jak Fisher uważał, że w początkowych etapach rozwoju gospodarczego dominujące znaczenie ma sektor rolniczy, na wyższych etapach rozwoju przeważające znaczenie ma sektor przemysłowy, natomiast $\mathrm{w}$ państwach najbardziej rozwiniętych sektor usługowy. Twierdził, że poszczególne sektory gospodarki charakteryzują się niejednakową dynamiką wydajności pracy. Opierając się na tym założeniu, sądził, że przyspieszenie rozwoju gospodarczego może być efektem przepływu siły roboczej z mniej do bardziej wydajnych sektorów gospodarki. Clark do sektora usług zalicza zarówno usługi konsumpcyjne, jak i usługi na rzecz procesu produkcyjnego. Za kryterium wyodrębnienia sektora usług przyjął niematerialny charakter rezultatów pracy.

Poglądy Fishera i Clarka kontynuował Fourastié, który także twierdził, że w procesie ewolucji ekonomicznej następuje spadek znaczenia sektora rolniczego, wzrost, a następnie spadek znaczenia sektora przemysłowego oraz wzrost znaczenia sektora usługowego. Fourastié kształtował swą teorię w okresie po II wojnie światowej. W odróżnieniu od Fishera i Clarka nie postulował aktywnej ingerencji państwa przy dokonywaniu zmian w kierunkach rozwoju sektorów 
gospodarki. Koncepcję podziału gospodarki opierał na podstawie klasyfikacji zawodowej. Prowadził badania nad ogólną ewolucją ekonomiczną społeczeństw, a podstawą wyodrębnienia sektora usług był charakter wykonywanej pracy. Zdaniem Fourastiégo cechą sektora usług jest zatrudnienie pracowników umysłowych. W poglądach autorów istniały pewne różnice na temat dziedzin zaliczanych do poszczególnych sektorów. Fisher i Clark dążyli w swych pracach do wyodrębnienia sektora usług poprzez analizę kształtowania się elastyczności popytu, zaś Fourastié zwracał uwagę na analizę strony podażowej, twierdząc, że postęp techniczny i wydajność pracy kształtują się na najwyższym poziomie w sektorze usług. Pomimo występujących różnic zgodnie twierdzili, że wraz $\mathrm{z}$ rozwojem gospodarczym zmniejsza się rola rolnictwa w gospodarce; początkowo rośnie, a następnie stabilizuje i zmniejsza znaczenie przemysłu i budownictwa oraz rośnie znaczenie sektora usług. Każdy z tych badaczy rolnictwo przypisał do sektora I, przemysł przetwórczy do sektora II, natomiast najważniejsze kategorie usług do sektora III.

Koncepcja teorii trzech sektorów gospodarki ulegała wielokrotnym modyfikacją, niejednokrotnie poddawano dyskusji jej uniwersalność i podważano, niektóre założenia wyjściowe (Kwiatkowski 1980, s. 191-192).

Pomimo różnej akceptacji poglądów Fishera, Clarka i Fourastiégo, teoria trzech sektorów ulegała dalszemu rozwojowi zarówno poprzez pewne jej weryfikacje i modyfikacje oraz wprowadzanie nowych pomysłów. Znaczenie usług w trójsektorowym podziale gospodarki było przedmiotem badań wielu ekonomistów, należeli do nich między innymi: Wolfe $(1955)$, Fuchs $(1965,1968)$ oraz Stigler (1956). Uniwersalizm panujących trendów podkreślają: Riddle, Ott, Tatam, Kutscher, Mark, Kravis (por. Grubel, Walker 1993, s. 232-265).

Według Szukalskiego (2009) teoria trzech sektorów z biegiem czasu uległa dezaktualizacji, zwłaszcza teza Fourastié o nikłej absorpcji techniki przez sektor III. Podział gospodarki w tradycyjnym ujęciu na trzy sektory pozwala jednak na uchwycenie zmian dokonujących się w strukturze gospodarki i zdefiniowanie procesów charakteryzujących te zmiany w większości rozwiniętych państw. Do procesów powodujących te zmiany należy zaliczyć: deagraryzację, deindustrializację i tertiaryzację (por. Lichniak 2010). Pierwszy z wymienionych procesów oznacza spadek znaczenia sektora rolnego w gospodarce, drugi polega na zmniejszającej się roli przemysłu i budownictwa poprzez spadający udział zatrudnienia $\mathrm{w}$ zatrudnieniu ogółem. Tertiaryzacja thumaczona jest jako wzrost znaczenia sektora usług $\mathrm{w}$ gospodarce $\mathrm{i}$ wzrost udziału zatrudnienia w zatrudnieniu ogółem. Szukalski (2004, s. 48) zwraca uwagę na proces serwicyzacji, twierdząc, że jest to proces ,wzrostu znaczenia usług w gospodarce, wyrażającego się zarówno wzrostem udziału sektora III, jak i rozszerzaniem rozmaitych funkcji usługowych w pozostałych sektorach (I i II)". 
Teoria trzech sektorów zawiera zarówno elementy racjonalne, jak i elementy nieracjonalne, niemniej jednak skłania do zastanowienia się nad jej wkładem w poznanie procesów rozwojowych oraz jej praktycznym znaczeniem. Przedstawiciele teorii trzech sektorów, odchodząc od analiz o charakterze agregatowym, stworzyli możliwości dla uchwycenia zmian dokonujących się w strukturze gospodarki. Podejście takie stało się punktem wyjścia do badań współzależności zmian strukturalnych i procesów rozwoju. Podział gospodarki na trzy sektory umożliwiał analizę struktury gospodarczej, zmiany strukturalne w gospodarce oraz uchwycenie prawidłowości przekształceń strukturalnych w gospodarce (Kwiatkowski 1980, s. 222-226).

Ponadto dostrzeżono, że teoria trzech sektorów gospodarki ma także znaczenie praktyczne. Teoria ta uzasadnia potrzebę prowadzenia określonej polityki strukturalnej oraz usiłuje wskazać przyszłe kierunki zmian strukturalnych w państwach, które znajdują się na niższym etapie rozwoju gospodarczego. Zgodnie z „teorią” droga rozwoju krajów będących na niższym etapie jest wyznaczana przez przekształcenia strukturalne, dokonujące się w państwach o wyższym poziomie rozwoju. Niemniej jednak przemiany w krajach wysoko rozwiniętych mogą określać jedynie ogólny kierunek rozwoju, a nie gotowy program polityki strukturalnej w krajach o niższym szczeblu rozwoju gospodarczego. Należy podkreślić, że zmiany strukturalne w gospodarce uważane były nie tylko za następstwo dokonującego się rozwoju gospodarczego, ale także istotny warunek tego rozwoju.

Omówiona teoria trzech sektorów ze względu na brak uwzględniania przy analizie struktury gospodarczej czynników nieregularnych nie mogła w pełni wyjaśnić przyczyn kształtowania się określonej struktury gospodarczej w niektórych państwach. Twórcy teorii trzech sektorów zwracali uwagę na znaczenie dwóch grup czynników w procesie przekształcenia struktury w gospodarce, czyli czynniki tkwiące po stronie popytu oraz czynniki po stronie produkcji. Stwierdzono, że przekształcenia struktury popytu konsumpcyjnego oraz różna dynamika wydajności pracy $\mathrm{w}$ poszczególnych sektorach stanowią istotne czynniki zmian strukturalnych $\mathrm{w}$ gospodarce.

Pewne wnioski wynikające z koncepcji trzech sektorów przedstawia Szukalski (2001, s. 11-12), twierdząc, że:

1. „Każda gospodarka charakteryzuje się trójsektorową strukturą, na którą składają się: sektor pierwotny (rolnictwo, rybołówstwo, leśnictwo), sektor drugi (przemysł, budownictwo), sektor trzeci (szeroko rozumiane usługi)".

2. Zgodnie z procesem rozwoju gospodarczego trójsektorowa struktura ulega przekształceniom, odpowiednio do stadium rozwoju obserwujemy dominacje sektora I (stadium I), następnie przeważa produkcja przemysłowa (stadium II) i dominacja usług (stadium III). 
3. Zgodnie z pojawianiem się określonego stadium rozwoju obserwuje się przesunięcia $\mathrm{w}$ strukturze zasobów pracy, kapitału, początkowo z sektora pierwotnego do sektora drugiego, a następnie $\mathrm{z}$ sektora drugiego do sektora trzeciego.

4. Pojawiają się zmiany po stronie popytu konsumpcyjnego, popyt społeczny przesuwa się od dóbr podstawowych na dobra trwałego użytku, a następnie na usługi.

Sektorowe zmiany strukturalne mają miejsce także po stronie czynników podażowych, głównie postępu technicznego, którego znaczenie podkreślał Fourastié. Postęp techniczny, będący źródłem wzrostu wydajności pracy, koncentruje się głównie w sektorze I i II, natomiast specyficzny charakter usług ogranicza możliwość absorpcji postępu technicznego, z czego wynika niższa produktywność sektora III, który, by podołać rosnącemu zapotrzebowaniu na usługi, musi zwiększać zatrudnienie. Ze względu na postęp techniczny i wzrost wydajności pracy w sektorze I i II następuje redukcja zatrudnienia, a zwolniona siła robocza w dużej mierze znajduje zatrudnienie w sektorze III. W konsekwencji dochodzi do wzrostu zatrudnienia w usługach i udziału tego sektora w globalnym zatrudnieniu, co świadczy o nieuchronności przekształceń w strukturze produkcji i zatrudnienia $\mathrm{w}$ gospodarce $\mathrm{z}$ korzyścią dla sektora usług.

Podział gospodarki na trzy sektory stanowi podstawę badań struktury gospodarczej i zachodzących w niej zmian strukturalnych. Obserwowane w rozwijającej się gospodarce przemiany strukturalne są powodowane niejednakowym rozwojem poszczególnych działów oraz sektorów gospodarki. Przybliżenie teorii trzech sektorów, będącej teorią przemian struktury gospodarczej, pozwala na podjęcie dalszych analiz sektora usług.

\subsection{Pojęcie, cechy i funkcje sektora usług}

Ze względu na złożoność pojęcia usług w literaturze można znaleźć wiele definicji, których znajomość jest niezbędna do zrozumienia istoty usług. Przy określaniu istoty usług wyodrębnia się dwa podejścia (Okulas 1998):

- makroekonomiczne, obejmujące działy gospodarki nie należące do sektora rolniczego i przemysłowego;

- mikroekonomiczne oparte na analizie faz procesu reprodukcji usług.

W podejściu mikroekonomicznym wyodrębnia się trzy kierunki badań polegające na utożsamianiu usług $\mathrm{z}$ dobrami niematerialnymi, z czynnościami oraz na utożsamianiu produkcji usług $\mathrm{z}$ ich świadczeniem.

Próbę usystematyzowania definicji usług podjął Rogoziński (1993), starając się uporządkować je w jednorodne grupy. Do najczęściej przytaczanych należą definicje przedstawione przez Daszkowską (1998): 
- negatywne oparte na założeniu, że to, co nie jest wytworzeniem dóbr materialnych ,stanowi działalność usługowa, podejście takie reprezentuje Lange (1959) i Kotler (1994);

- enumeratywne, polegające na wyliczaniu gałęzi, branż i rodzajów działalności zaliczanych do sektora usług, przedstawicielem takiego podejścia jest Wiśniewski (1965);

- konstruktywne - zwracające uwagę na trzy elementy je opisujące, charakteryzujące potencjał, proces i wynik, w polskiej literaturze podejście takie prezentuje Kramer (1994).

Kracke (1999) także wyróżnia trzy rodzaje definicji, są to definicje:

- pozytywne, których dążeniem jest stworzenie ogólnej definicji, obejmującej wszystkie rodzaje usług,

- wskazujące podstawowe cechy usług,

- enumeratywne, wyliczające rodzaje działalności powszechnie uznawanych za usługowe.

Różnorodność klasyfikowania definicji usług wpływa na różną ich przydatność metodologiczną. Definicje wyróżnione jako enumeratywne koncentrują się na wyliczaniu rodzajów działalności usługowej, nie uwzględniają kryterium ich wyodrębniania, przez co nie zawsze stają się przydatne w badaniach lub zawężają ich obszar badawczy. Definicje negatywne wskazują na działania produkcyjne, dotyczące wytwarzania dóbr materialnych, nie wyjaśniając szerzej sensu pojęcia usług. Uważa się, że najbardziej przydatne, dające szerokie możliwości interpretacyjne, są definicje konstruktywne, w których dąży się do określenia zakresu pojęcia usługi poprzez zwrócenie uwagi na specyficzne cechy usług lub procesu ich produkcji.

W tablicy 1.1 i 1.2 przedstawione zostały definicje usług sformułowane przez autorów reprezentujących różne dyscypliny naukowe.

Brak w literaturze jednej uniwersalnej definicji wyjaśniającej pojęcie usługi wynika z różnorodności działań, wchodzących w zakres czynności usługowych oraz z pojawiania się nowych działań, które są wynikiem rozwoju gospodarczego i służą zaspokajaniu ludzkich potrzeb.

Zgodnie z Polską Klasyfikacją Wyrobów i Usług (GUS) pod pojęciem usług rozumie się:

- wszelkie czynności świadczone na rzecz jednostek gospodarczych prowadzących działalność o charakterze produkcyjnym, tzn. usługi dla celów produkcji nietworzące bezpośrednio nowych dóbr materialnych;

- wszelkie czynności świadczone na rzecz jednostek gospodarki narodowej oraz na rzecz ludności, przeznaczone dla celów konsumpcji indywidualnej, zbiorowej i ogólnospołecznej. 
Tablica 1.1. Wybrane definicje usług z literatury obcej

\begin{tabular}{|c|c|}
\hline Autorzy & Definicje \\
\hline $\begin{array}{l}\text { Amerykańskie Stowa- } \\
\text { rzyszenie Marketingu } \\
\text { (1960) }\end{array}$ & $\begin{array}{l}\text { "Usługi to aktywności, korzyści lub satysfakcja, które są oferowane na } \\
\text { sprzedaż bądź dostarczane w powiązaniu ze sprzedażą innych towarów”. }\end{array}$ \\
\hline $\begin{array}{l}\text { Regan } \\
(1963)\end{array}$ & $\begin{array}{l}\text { „Usługi są nienamacalnymi dobrami, z których można czerpać satysfak- } \\
\text { cję bezpośrednio (np. transport) lub przez zakup innych towarów } \\
\text { i usług (np. dostawa, kredyt bankowy)”. }\end{array}$ \\
\hline $\begin{array}{c}\text { Judd } \\
(1964)\end{array}$ & $\begin{array}{l}\text { Usługa to „transakcja rynkowa, w której wymiana przedmiotu nie jest } \\
\text { związana z transferem własności”. }\end{array}$ \\
\hline $\begin{array}{l}\text { Blois } \\
(1974)\end{array}$ & $\begin{array}{l}\text { „Usługa jest aktywnością zaoferowaną na sprzedaż, która generuje } \\
\text { satysfakcję i korzyści bez konieczności wymiany w formie dobra mate- } \\
\text { rialnego". }\end{array}$ \\
\hline Hill (1977) & $\begin{array}{l}\text { "Usługa jest to zmiana dotycząca osoby lub towaru należącego do okre- } \\
\text { ślonego podmiotu gospodarczego działalność zgody osoby lub podmiotu } \\
\text { gospodarczego zainteresowanych określoną usługą. }\end{array}$ \\
\hline $\begin{array}{l}\text { Charles, Schewe, } \\
\text { Reuben, Smith (1980) }\end{array}$ & $\begin{array}{l}\text { „Usługi są aktywnościami, korzyściami lub satysfakcjami, które są ofero- } \\
\text { wane do sprzedaży lub są dostarczane w powiązaniu ze sprzedażą dóbr”. }\end{array}$ \\
\hline Stanton (1981) & $\begin{array}{l}\text { „Usługa to występująca odrębnie działalność nieprzynosząca material- } \\
\text { nego efektu, dostarczająca nabywcy określonych korzyści, które nie sa } \\
\text { koniecznie związane ze sprzedażą produktów”. }\end{array}$ \\
\hline Groonross (1990) & $\begin{array}{l}\text { Usługi są „działalnością lub zbiorem działalności o mniej lub bardziej } \\
\text { niematerialnej naturze, które normalnie, ale niekoniecznie, mają miejsce } \\
\text { podczas kontaktu klienta z pracownikiem świadczącym usługe i/lub } \\
\text { fizycznymi zasobami i/lub systemami przedsiębiorstwa usługowego, } \\
\text { które zapewniają rozwiązanie problemów klienta”. }\end{array}$ \\
\hline Groonross (1994) & $\begin{array}{l}\text { Usługa to „obiekt procesu transakcyjnego oferowany przez firmy i } \\
\text { instytucje, które generalnie oferują usługi i które postrzegają się za } \\
\text { organizacje usługowe”. }\end{array}$ \\
\hline $\begin{array}{l}\text { Payne } \\
(1996)\end{array}$ & $\begin{array}{l}\text { „Usługa jest to każda czynność zawierająca w sobie element niemate- } \\
\text { rialności, która polega na oddziaływaniu na klienta lub przedmiot bądź } \\
\text { nieruchomości znajdujące się w jego posiadaniu, a która nie powoduje } \\
\text { przeniesienia prawa własności. Przeniesienie prawa własności może } \\
\text { jednak nastąpić, a świadczenie usługi może być lub też nie być ściśle } \\
\text { związane z dobrem materialnym”. }\end{array}$ \\
\hline $\begin{array}{l}\text { Kotler, Armstrong, } \\
\text { Saunders i Wong } \\
\text { (2002) }\end{array}$ & $\begin{array}{l}\text { „Usługa to wszelka działalność lub korzyść, którą jedna ze stron może } \\
\text { zaoferować drugiej, z zasady niematerialna i nie prowadząca do uzyska- } \\
\text { nia jakiejkolwiek własności”. }\end{array}$ \\
\hline $\begin{array}{l}\text { Gilmore } \\
(2006)\end{array}$ & $\begin{array}{l}\text { Usługe określa jako „podstawowy produkt, czyli komercyjny wytwór } \\
\text { organizacji usługowej; produkt wzbogacony, czyli każda czynnośc } \\
\text { uzupełniająca, która zmierza do wzmocnienia oferty podstawowego } \\
\text { produktu; wsparcie podstawowego produktu, czyli każde działanie } \\
\text { ukierunkowane na produkt lub klienta, a podejmowane już po dostar- } \\
\text { czeniu produktu; czyste działanie, czyli sposób zachowania ukierunko- } \\
\text { wany na pomaganie klientowi albo służenie mu radą”. }\end{array}$ \\
\hline
\end{tabular}

Źródło: opracowanie własne na podstawie literatury przedmiotu. 
Tablica 1. 2. Definicje usług według polskich autorów

\begin{tabular}{|c|c|}
\hline Autor & Definicje \\
\hline 1 & 2 \\
\hline $\begin{array}{l}\text { Krzyżanowski } \\
\quad(1947)\end{array}$ & $\begin{array}{l}\text { Istota usług ,polega na wytworzeniu pracy, wydatkowaniu pewnej ilości } \\
\text { pracy, wywołaniu pewnego efektu, zaspokajającego potrzebę spożywcy”. }\end{array}$ \\
\hline $\begin{array}{l}\text { Lange } \\
(1959)\end{array}$ & $\begin{array}{l}\text { Usługi to: „wszelkie czynności związane bezpośrednio lub pośrednio (np. } \\
\text { przy podziale produktów) z zaspokojeniem potrzeb ludzkich, ale nie słu- } \\
\text { żące bezpośrednio do wytwarzania przedmiotów”. }\end{array}$ \\
\hline $\begin{array}{l}\text { Wiśniewski } \\
\text { (1965) }\end{array}$ & $\begin{array}{l}\text { „Usługi stanowią czynności wytwarzające wartości użytkowe, które służą } \\
\text { do zaspokojenia potrzeb ludzkich w sposób bezpośredni lub pośredni, lecz } \\
\text { nie znajdują odzwierciedlenia w wytwarzaniu nowych dóbr materialnych”. }\end{array}$ \\
\hline Lipiński (1965) & $\begin{array}{l}\text { „Usługi we właściwym znaczeniu polegają na produkcji samoistnych } \\
\text { wartości użytkowych, nieposiadających formy materialnej, służących do } \\
\text { zaspokajania odrębnych, samoistnych, wyższych rodzajów potrzeb”. }\end{array}$ \\
\hline $\begin{array}{l}\text { Polarczyk } \\
\text { (1971) }\end{array}$ & $\begin{array}{l}\text { „Usługa jest praca wytwórcza, której efektem jest wartość użytkowa } \\
\text { odtworzona lub nadana istniejącemu i ukształtowanemu już wcześniej } \\
\text { obiektowi (produktowi materialnemu, informacji, osobie lub grupie spo- } \\
\text { łecznej) w wyniku działania w czasie pracy na strukturę tego obiektu”. }\end{array}$ \\
\hline $\begin{array}{l}\text { Kotarbiński } \\
\text { (1973) }\end{array}$ & $\begin{array}{l}\text { „Usługą dla podmiotu Y ze względu na określona jego potrzebe jest czyn- } \\
\text { ność podmiotu X wypełniająca odcinek czasu T, zawsze i tylko jeżeli jest } \\
\text { ona wykonana przez podmiot X w celu zadośćuczynienia tej potrzebie } \\
\text { podmiotu Y przez zmianę w tworzywie zamierzoną, wypełniającą tenże } \\
\text { odcinek czasu T”. }\end{array}$ \\
\hline $\begin{array}{c}\text { Niewadzi } \\
(1975)\end{array}$ & $\begin{array}{l}\text { „Usługami nazywamy świadczenie społecznie użytecznych czynności nie } \\
\text { związane bezpośrednio z wytwarzaniem produktów przez jednostki trud- } \\
\text { niące się tym zawodowo oraz przedsiębiorstwa i instytucje specjalnie do } \\
\text { tego powołane na zasadzie społecznego podziału pracy”. }\end{array}$ \\
\hline $\begin{array}{c}\text { Daszkowska } \\
\text { (1987) }\end{array}$ & $\begin{array}{l}\text { „Usługa w sensie gospodarczym jest użytecznym produktem niematerial- } \\
\text { nym, który jest wytwarzany w wyniku pracy ludzkiej (czynności) w pro- } \\
\text { cesie produkcji, przez oddziaływanie na strukturę określonego obiektu } \\
\text { (człowieka traktowanego jako osoba fizyczna, intelekt czy cząstka okre- } \\
\text { ślonej społeczności albo przedmiotu materialnego), w celu zaspokojenia } \\
\text { potrzeb ludzkich”. }\end{array}$ \\
\hline Naumowicz (1992) & $\begin{array}{l}\text { „Usługi są to różnorodne czynności społecznie użyteczne, wykonywane } \\
\text { zawodowo na rzecz państwa, gospodarki narodowej (w tym wytwórczo- } \\
\text { ści) oraz społeczeństwa (w tym konsumpcji), jego komórek i poszczegól- } \\
\text { nych członków, tworzące warunki do ich funkcjonowania”. }\end{array}$ \\
\hline $\begin{array}{l}\text { Rogoziński } \\
\text { (1993) }\end{array}$ & $\begin{array}{l}\text { „Usługa to podejmowane na zlecenie świadczenie pracy i korzyści mające } \\
\text { na celu wzbogacenie walorów osobistych lub wolumenu wartości użytko- } \\
\text { wych, jakimi usługobiorca dysponuje”. }\end{array}$ \\
\hline $\begin{array}{l}\text { Pluta-Olearnik } \\
\text { (1993) }\end{array}$ & $\begin{array}{l}\text { „Usługi to korzyści oferowane do sprzedaży w istocie swej niewymierne } \\
\text { i subiektywnie oceniane przez nabywców”. }\end{array}$ \\
\hline $\begin{array}{c}\text { Kramer } \\
(1994)\end{array}$ & $\begin{array}{l}\text { Usługi są to „wszelkie czynności związane z zaspokajaniem potrzeb ludz- } \\
\text { kich, niesłużące bezpośrednio do wytwarzania produktów”. }\end{array}$ \\
\hline
\end{tabular}


Tablica $1.2(\mathrm{~cd}$.

\begin{tabular}{|c|l|}
\hline 1 & \multicolumn{1}{|c|}{2} \\
\hline $\begin{array}{c}\text { Nowosielska } \\
\text { (1994) }\end{array}$ & $\begin{array}{l}\text { Usługi to „wszystkie prace (czynności) usługowe bez względu na ich } \\
\text { miejsce w klasyfikacji gospodarki narodowej, tj. zarówno usługi sklasyfi- } \\
\text { kowane w sektorach produkcyjnych gospodarki (w rolnictwie i leśnictwie } \\
\text { oraz przemyśle i budownictwie), jak i prace wykonane w działach usłu- } \\
\text { gowych (tj. nie będących produkcją rolniczą, przemysłową itd.”). }\end{array}$ \\
\hline $\begin{array}{c}\text { Garbarski Rutkow- } \\
\text { ski Wrzosek (2000) }\end{array}$ & $\begin{array}{l}\text { „Usługą jest działalność służąca zaspokajaniu potrzeb ludzkich, która nie } \\
\text { znajduje żadnego ucieleśnienia w nowych dobrach materialnych”. }\end{array}$ \\
\hline Kłosowski (2006) & $\begin{array}{l}\text { Usługi to „wszelka działalność o charakterze instytucjonalnym, skierowa- } \\
\text { na na podmiot, którym może być człowiek, jednostka gospodarcza lub } \\
\text { rzecz - w celu nadania jej nowej, zachowania lub odtworzenia istniejącej } \\
\text { wcześniej wartości, nie dająca produktu materialnego”. }\end{array}$ \\
\hline
\end{tabular}

Źródło: opracowanie własne na podstawie literatury przedmiotu.

Organizacja Narodów Zjednoczonych (ONZ), Międzynarodowy Fundusz Walutowy (MFW), Organizacja Współpracy Gospodarczej i Rozwoju (OECD) oraz Międzynarodowy Bank Odbudowy i Rozwoju (MBOiR) nie opracowały dotychczas uniwersalnej definicji usług, sektor usług określają poprzez wyliczenie poszczególnych działalności usługowych.

W pracach naukowych brak jednoznacznej definicji określającej usługi. Wśród przytoczonych definicji pojawiają się jednak pewne wspólne elementy, które wskazują na to, że usługi są:

- procesem,

- niematerialnym produktem,

- czynnościami zaspokajającymi określone potrzeby ludzkie,

- czynnościami o charakterze niematerialnym ,

- czynnościami tworzącymi wartości użytkowe.

$\mathrm{Na}$ podstawie definicji usług zostały wyodrębnione cztery podstawowe cechy usług odróżniające je od dóbr, są to:

- niematerialność - usługi są $\mathrm{w}$ większości przypadków nie związane z wytwarzaniem dóbr materialnych, a więc usługi nie mogą być ocenione przez potencjalnego nabywcę za pomocą zmysłów; usługi nie mogą być pokazywane;

- różnorodność - wynika z faktu, że usługi nie sąjednolite i trudno jest poddać je standaryzacji;

- nierozdzielność - polega na braku możliwości rozdzielności procesu produkcji, dystrybucji sprzedaży i konsumpcji;

- nietrwałość - nie ma możliwości magazynowania usług, ich wytwarzania i gromadzenia na zapas.

Usługi mogą być charakteryzowane także przez inne cechy. Sasser (1976) do cech charakteryzujących usługi, a jednocześnie odróżniających je od produktów, zalicza: bezpośredni charakter usług, polegający na braku możliwości ma- 
gazynowania, wysoki stopień interakcji z klientem, brak możliwości transportu oraz brak materialnego charakteru. Flejterski, Panasiuk, Perenc i Rosa (2005, s. 22): dokonując charakterystyki rynku usług, wymieniają następujące cechy:

- przyrodniczo-techniczne, polegające na braku rzeczowego charakteru usług, jedności produkcji i konsumpcji usług oraz braku możliwości produkcji usług na zapas;

- techniczno-eksploatacyjne (zdeterminowanie przestrzenne polegające na różnym geograficznie rozmieszczeniu popytu i podaży na określone usługi oraz sezonowość popytu i podaży);

- ekonomiczno-organizacyjne, do których zaliczamy: zróżnicowaną elastyczność popytu, znaczne zróżnicowanie popytu i podaży, zróżnicowaną substytucyjność popytu i podaży, komplementarność podażową oraz niewielką mobilność podażową.

Rozwój sektora usług spowodowany pojawieniem się nowoczesnych technologii informacyjnych i komunikacyjnych spowodowat, że wymienione cechy usług nie w pełni charakteryzują pojawiające się obecnie nowe rodzaje usług na rynku. Przykładem cechy, polegającej na braku konieczności przebywania w miejscu świadczenia usługi, są coraz bardziej popularne usługi elektroniczne, do których można zaliczyć usługi finansowe, bankowość elektroniczną, handel elektroniczny. Wymienione rodzaje są przykładem swoistego połączenia usług i wykorzystania nowych technologii. Usługi bankowe (e-bankowość) stanowią połączenie tradycyjnej usługi bankowej z usługą telekomunikacyjną (wykorzystanie telefonu, czy Internetu), podobnie handel elektroniczny (e-handel) przy wykorzystaniu technologii internetowej. Przykładem przekształcania się usług pod wpływem rozwoju technologii mogą być usługi edukacyjne, świadczone na odległość z wykorzystaniem radia, poczty (kursy korespondencyjne) czy Internetu (e-lerning). Obecnie możliwe jest również składowanie i magazynowanie produktów związanych z usługami świadczonymi dla masowego odbiorcy, co pozwala na osiagnnięcie korzyści skali (Skórska 2010).

Przytoczone cechy usług są uważane za wspólne dla całego sektora usług, należy jednak pamiętać, że różne rodzaje usług mogą być charakteryzowane także poprzez inne cechy, wynikające z ich specyfiki i funkcji, jakie pełnią w życiu społeczno-gospodarczym.

Sektor usług wpływa na produkcję, wymianę, konsumpcję, a także na życie ludności, pełni wiele różnych funkcji w gospodarce, między innymi:

- oddziałuje na wzrost gospodarczy, co wyraża się wpływem na poziom produktu krajowego brutto;

- kształtuje równowagę pieniężno-rynkową poprzez absorbowanie zarówno środków podstawowych ludności, jak i środków przeznaczonych do swobodnego dysponowania oraz kreowanie popytu na dobra i usługi komplementarne;

- wpływa na efektywność organizacyjną rynku; 
- obejmuje ponad połowę ludności aktywnej zawodowo, wpływając na inwestycje i rozwój naukowo-techniczny.

W celu dokładnego określenia funkcji usług należy przyjrzeć się ich rodzajom. Uwzględniając podział usług według PKD 2007 na 15 sekcji, możemy wyodrębnić cały szereg funkcji, wynikających bezpośrednio z podziału sektora usług, a mianowicie funkcje związane bezpośrednio z egzystencją człowieka, zaspokajające podstawowe potrzeby, funkcje związane $\mathrm{z}$ ochroną zdrowia i opieką społeczna, związane z zachowaniem bezpieczeństwa, edukacją oraz tzw. funkcje wyższego rzędu, polegające na zaspokajaniu potrzeb duchowych.

Sektor usług pełni w gospodarce wiele różnych funkcji zarówno o charakterze gospodarczym, jak i pozagospodarczym. Do funkcji gospodarczych zaliczamy (Flejterski, Panasiuk, Perenc, Rosa, 2005):

- obsługę procesów wytwórczych, polegającą na wytwarzaniu dóbr materialnych. Do sekcji spełniających te funkcje zaliczamy: transport, łączność, handel, działalność finansową i ubezpieczeniowa:

- zaspokajanie potrzeb bytowych ludności. Ten rodzaj funkcji wynika z rozwoju różnych dziedzin działalności usługowej, np. gospodarki komunalnej i mieszkaniowej, handlu, transportu, łączności i wielu innych;

- działania socjalne, polegające na świadczeniu usług związanych z opieką społeczną i ochroną zdrowia;

- oferty kulturotwórcze i oświatowe, wynikające z rozwoju ośrodków naukowobadawczych, kulturalnych i oświatowych;

- prace administracyjno-organizatorskie związane z prawidłowym funkcjonowaniem gospodarki;

- działalność naukowo-badawczą opartą na rozwoju badań naukowych.

Funkcje pozagospodarcze sektora usługowego to funkcje związane z obroną narodową, porządkiem publicznym oraz administracją. Usługi pełnią wiele funkcji i zaspokajają różne potrzeby zarówno indywidualne, jak i wynikające z życia w społeczeństwie. W literaturze coraz częściej zwraca się uwagę na funkcje doradcze usług związane $z$ ograniczaniem ryzyka w kwestiach finansowych i przy podejmowaniu różnego rodzaju decyzji. Daszkowska (1998) zwraca uwagę na funkcje usług $\mathrm{w}$ procesie reprodukcji społecznej zarówno w fazie produkcji, podziału, wymiany, jak i konsumpcji. W fazie produkcji funkcja usług polega na utrzymaniu w sprawności środków pracy oraz zapewnieniu odpowiednich warunków do podnoszenia kwalifikacji. Faza podziału określa, jaka część wytworzonych dóbr i usług przypada poszczególnym osobom czy jednostkom. Faza wymiany łączy proces produkcji, podziału i konsumpcji. Bardzo istotna jest faza konsumpcji, w której funkcja usług polega na przyspieszeniu tempa wzrostu stopy życiowej społeczeństwa. Innym podziałem funkcji usług jest podział wynikający z potrzeb konsumenta. Wyróżniamy tu dwa rodzaje usług: pierwotne związane $\mathrm{z}$ zaspokajaniem podstawowych potrzeb egzysten- 
cjalnych człowieka (np. żywieniowe, mieszkaniowe, bezpieczeństwa, zdrowotne) oraz wtórne związane z zaspokajaniem potrzeb wyższego rzędu (np. kultura, turystyka). Funkcje usług wraz rozwojem społeczeństwa, zmianami demograficznymi, politycznymi, gospodarczymi ulegają zmianom, rośnie także ich znaczenie we wszystkich dziedzinach życia.

Gospodarka oparta na usługach w większości państw rozwiniętych stała się dominującym typem gospodarki. Intensywny rozwój tego sektora oraz spadek dynamiki tradycyjnej produkcji wskazuje, że ze względu na wielkość przychodu oraz liczbę zatrudnionych udział sektora usług w większości państw wysoko rozwiniętych przekracza $60 \%$.

Bogacenie się społeczeństwa wpływa na wzrost wydatków na usługi związane z wypoczynkiem, rozrywką i turystyka. Dynamiczny tryb życia wpływa z kolei na rozwój usług telekomunikacyjnych. Coraz większa świadomość i dbałość o zdrowie wpływają na korzystanie z usług zdrowotnych i edukacyjnych. Zawiłe procedury bankowe, ubezpieczeniowe i inwestycyjne spowodowały wzrost popytu na usługi w zakresie doradztwa finansowego. Przytoczone przykłady świadczą o silnym wpływie sektora usług na nasze życie i wyraźnej jego dominacji.

\subsection{Klasyfikacja usług}

Klasyfikacja to logiczny wielostopniowy podział przedmiotów lub faktów na klasy, według przyjętych wcześniej zasad. Celem klasyfikacji jest (Mudie, Cottam, 1998, s. 23): „stwierdzenie, czy pewne cechy lub zachowania są na tyle ważne i odmienne, że zasługują na oddzielne traktowanie, określenie stopnia, w jakim pewne cechy i zachowania mogą odnosić się do różnych kategorii, ułatwienie zrozumienia".

Można wyróżnić wiele różnych klasyfikacji usług uwzględniających różne cechy i kryteria. Istotne jest, aby dana klasyfikacja była jednoznaczna, rozłączna i wyczerpująca, ale jak dotąd brak jest jednej, przez wszystkich akceptowanej klasyfikacji usług. Ekonomiści najczęściej posługują się klasyfikacją usług opartą na sektorze działalności lub wykonywanym zawodzie. Specjaliści z dziedzin zarządzania przy klasyfikacji usług zwracają uwagę na charakterystyki procesów i działań o charakterze usługowym. Ze względu na podjęte rozważania słuszne wydaje się zwrócenie uwagi na różne klasyfikacje. Pierwsze próby podziału sektora usług na podstawie postępu gospodarczego i procesów uprzemysłowienia podjął Katouzian (1970). Dokonał on podziału usług na stare, nowe i komplementarne. Do grupy usług starych zaliczył między innymi usługi o charakterze naprawczym, hotelowe oraz handel domokrążny. Grupę usług nowych reprezentowały: usługi edukacyjne, ochrona zdrowia oraz związane z rekreacją i wy- 
poczynkiem. Usługi komplementarne to te, „które służą zwiększeniu mobilności kapitału oraz dystrybucji dóbr wytwarzanych w sektorach przemysłu i rolnictwa" (Rudawska 2009, s. 15), np. usługi finansowe, transport, spedycja, handel. Zachodzące zmiany w sektorze usług oraz formy ich świadczenia spowodowane między innymi postępem technicznym spowodowały, że obecnie podział taki traci na znaczeniu.

Próbę rewolucji podziału sektora usługowego w latach siedemdziesiątych XX w. podjął Gelinger (1976), wyodrębniając pięć subsektorów usługowych:

- tradycyjny, np. usługi szewskie, fryzjerskie;

- uprzemysłowiony związany z produkcja, np.: transport, finanse;

- biurokratyczny, np. usługi administracji publicznej;

- oparty na rozwoju osobowości człowieka, np.: edukacja, ochrona zdrowia, rekreacja;

- łączący usługi w zakresie doradztwa ekonomiczno-prawnego i usługi wykorzystujące nowe technologie.

Kabaj (1972, s. 169-170) zaproponował klasyfikację sektora usług, opierając się na funkcjach spełnianych w procesie reprodukcji rozszerzonej na podstawie kryterium wzrostu. Wyróżnił on cztery grupy usług:

- I grupa, będąca przedłużeniem procesu produkcji dóbr materialnych (transport i komunikacja, handel i gastronomia);

- II grupa, preferująca rozwój zasobów ludzkich (nauka i badania naukowe, szkolnictwo, oświata i kultura, ochrona zdrowia i opieka socjalna, gospodarka komunalna i mieszkaniowa);

- III grupa, zawierająca usługi związane z funkcjonowaniem nowoczesnego państwa (administracja publiczna, instytucje sprawiedliwości, instytucje finansowe i ubezpieczeniowe);

- IV grupa to usługi konsumpcyjne dla ludności oraz pozostała działalność usługowa.

$\mathrm{Na}$ gruncie literatury polskiej podziału sektora usług na trzy tzw. podsfery dokonał także Niewadzi (1982). Zaliczamy do nich usługi:

- związane z produkcja, np.: handel, transport, usługi finansowe, nauka;

- wpływające na osobowość człowieka, np.: ochrona zdrowia i opieka społeczna, edukacja, rekreacja;

- nastawione na warunki bytowe, np. gospodarka komunalna i mieszkaniowa.

Rogoziński (2000), określając usługę jako obsługę, wyróżnił obsługę:

- nabywcy (obsługa gospodarstw domowych w zakresie podstawowych usług np.: remonty, naprawy, handel);

- osobistą ( usługi wyższe niż podstawowe, np. korzystanie z restauracji);

- osobowości (tzw. usługi wyższego rzędu, np. usługi turystyczne, rozrywkowe). 
Daszkowska (1998) uważa, że kryteria klasyfikacji mają ścisły związek i wynikają z treści przytaczanych definicji usług. W związku z takim podejściem możemy wymienić następujące kryteria:

- przeznaczenia danej usługi, w ramach którego wyróżniamy usługi o charakterze produkcyjnym, konsumpcyjnym i ogólnospołecznym;

- rodzaju wyniku pracy, do kryterium tego możemy zaliczyć usługi renowacyjne, informacyjne, dystrybucyjne, rekreacyjne, oświatowo-kulturalne i organizacyjne;

- rodzaju wykonywanej pracy, w ramach tego kryterium możemy wyodrębnić pięć rodzajów czynności, są to czynności oddziałujące na przedmioty lub obiekty, czynności urządzeń i pomieszczeń, czynności zaspokajające fizyczne i psychiczne potrzeby człowieka, czynności porządkowo-organizacyjne gospodarki narodowej i społeczeństwa oraz czynności na indywidualne życzenie klienta;

- obiektu działania, możemy tu wyodrębnić usługi produkcyjne, osobiste, informacyjne i kierownicze;

- odbiorcy, według którego usługi możemy podzielić na usługi dla ludności i usługi dla gospodarki uspołecznionej;

Odpłatności, w skład którego wchodzą usługi rynkowe i pozarynkowe.

Próbę uporządkowania klasyfikacji usług podjęła także Filipiak i Panasiuk (2008), wyodrębniając cztery grupy usług:

- infrastrukturalne, których działanie jest oparte na systemie technicznym i które adresowane są do ogółu konsumentów, np.: usługi transportowe, pocztowe, energetyczne, komunalne;

- bytowe, umożliwiające sprawne funkcjonowanie gospodarstw domowych;

- osobiste, uwzględniające ludzkie potrzeby, np.: zdrowie, edukacje, wygląd;

- profesjonalne związane z posiadaniem przez usługodawcę określonych umiejętności i kwalifikacji potwierdzonych dyplomem czy dokumentem, dającym prawo wykonywania zawodu.

Przytoczone podziały usług nie rozwiązują wszystkich problemów związanych z ich klasyfikacją, trudno dokonać jest klasyfikacji uwzględniającej dynamiczny rozwój usług opartych na nowoczesnych technologiach i przenikaniu sektora usług do pozostałych sektorów gospodarki. Klasyfikację usług można także oprzeć na kilku kryteriach jednocześnie, podział taki nazywany jest typizacją usług. Do najczęściej przytaczanych typizacji usług należy podział zaproponowany przez Carpa (1974), który wyodrębnił cztery klasy usług na podstawie obiektu świadczonej usługi oraz materialnych właściwości, które są związane z:

- obsługą osób,

- obsługą rzeczy,

- przekazywaniem rzeczy i informacji,

- dobrami nominalnymi (pieniądze, pożyczki).

Z kolei typizacja stworzona przez Meyera (por. Flejterski, Panasiuk, Perenc, Rosa 2005) wyróżnia poszczególne typy przedsiębiorstw usługowych na podstawie czterech kryteriów: 
- formy prawnej (usługi oferowane przez przedsiębiorstwa prywatne, publiczne oraz instytucje publiczne i samorządowe, organizacje i stowarzyszenia),

- kooperacji (firmy usługowe oferujące klientom różne usługi będące wynikiem współpracy z innymi firmami usługowymi),

- formy organizacyjnej (przedsiębiorstwa pojedyncze i filialne),

- sposobu świadczenia usługi rozumianej jako metoda ustalania ceny (taryfowe lub umowne), liczba świadczonych usług i ich rodzaj (uniwersalne i specjalne) oraz przedmiot oddziaływań (człowiek, obiekt).

Nieco inną typizację usług przedstawia Lovelock (1983), a składa się ona z pięciu systemów obejmujących:

- charakter usługi,

- wzajemne powiązania pomiędzy usługobiorcą a usługodawca,

- dostosowanie usług do indywidualnych potrzeb klienta,

- podaż i popyt na usługi,

- sposób dostarczania świadczonych usług klientom.

$\mathrm{Na}$ podstawie szerokiego przeglądu literatury Cyrek (2012) wyróżnia dwa dominujące podejścia określające zakres usług:

- sektor usług wyróżniany jest na podstawie cech charakteryzujących poszczególne rodzaje działalności gospodarczej,

- sektor III gospodarki określany jest w sposób enumeratywny, polegający na wyliczeniu rodzajów działalności (sekcji) wchodzących w jego ramy.

Różnorodność klasyfikacji usług najczęściej wynika z treści definicji usług, a ich wielość powoduje, że wzajemnie się one uzupełniają. Dokonując wyboru kryterium, należy uwzględnić cel badania oraz dostępność danych statystycznych, dlatego też słuszne wydaje się przybliżenie klasyfikacji PKD. W styczniu 2008 r. rozporządzeniem Rady Ministrów z 24 grudnia 2007 r. została wprowadzona nowa Polska Klasyfikacja Działalności (PKD 2007), zastępując PKD 2004. PKD 2007 zawiera zmiany, które zostały wprowadzone w klasyfikacji Organizacji Narodów Zjednoczonych oraz klasyfikacji Unii Europejskiej. Zmiany PKD 2004 na PKD 2007 wynikały z potrzeby zwiększenia harmonizacji klasyfikacji w porównaniach międzynarodowych oraz ze względu na intensywne zmiany w rozwoju nowych technologii i rodzajów działalności. PKD-2007 podobnie jak PKD-2004 jest klasyfikacją pięciopoziomową, nie zawiera jednak podsekcji:

poziom I (sekcja) zawiera kategorie rodzajów działalności oznaczone literami od A do $\mathrm{U}(21$ sekcji),

poziom II (dział), oznaczony 2-cyfrowym kodem numerycznym od 0.1 do 99 (88 działów),

poziom III (grupa), oznaczony 3-cyfrowym kodem numerycznym od 01.1 do 99.0 (272 grupy),

poziom IV ( klasa), oznaczony 4-cyfrowym kodem numerycznym od 01.11 do 99.0 (615 klas), 
poziom V (podklasa), oznaczony 5-znakowym kodem alfanumerycznym i obejmuje 654 grupowania.

Sektor usług składa się z podmiotowo określonych jednostek, których podstawowy rodzaj działalności sklasyfikowano według PKD w następujących sekcjach:

G - Handel hurtowy i detaliczny; naprawa pojazdów samochodowych, włączając motocykle;

$\mathrm{H}$ - Transport i gospodarka magazynowa;

I - Działalność związana z zakwaterowaniem i usługami gastronomicznymi;

$\mathrm{J}$ - Informacja i komunikacja;

$\mathrm{K}$ - Działalność finansowa i ubezpieczeniowa;

L - Działalność związana z obsługą rynku nieruchomości;

M - Działalność profesjonalna, naukowa i techniczna;

N - Działalność w zakresie usług administrowania i działalność wspierająca;

$\mathrm{O}$ - Administracja publiczna i obrona narodowa; obowiązkowe ubezpieczenia społeczne;

$\mathrm{P}$ - Edukacja;

Q - Opieka zdrowotna i pomoc społeczna;

$\mathrm{R}$ - Działalność związana z kulturą, rozrywką i rekreacją;

$\mathrm{S}$ - Pozostała działalność usługowa;

T- Gospodarstwa domowe zatrudniające pracowników; gospodarstwa domowe produkujące wyroby i świadczące usługi na własne potrzeby;

$\mathrm{U}$ - Organizacje i zespoły eksterytorialne.

Usługi można także podzielić na: rynkowe i nierynkowe. Do pierwszej grupy zalicza się: handel, naprawy, działalność hotelarską i gastronomiczną, transport, gospodarkę magazynową i łączność, pośrednictwo finansowe i usługi finansowe, a także obsługę nieruchomości i firm. Są to sekcje G, H, I, J, K, O, P. Usługi nierynkowe wynikają z funkcji państwa, zaliczamy do nich: ochronę zdrowia i opiekę społeczną, edukację, obronę narodową oraz administrację publiczną. Sekcjom tym przyporządkowano odpowiednio symbole L, M i N. Na uwagę zasługuje także grupa usług określana jako usługi biznesowe. Ten rodzaj usług głęboko wpływa na tempo wzrostu gospodarki oraz poziom konkurencyjności. Do usług biznesowych zaliczamy (Ministerstwo Gospodarki; Ewolucja sektora ustug $w$ Polsce w latach 1995-2008 2010):

- wynajem samochodów osobowych i innych środków transportu,

- wynajem różnego rodzaju maszyn i urządzeń,

- porady i doradztwo dotyczące sprzętu komputerowego i oprogramowania,

- działania związane z przetwarzaniem danych i bazami danych,

- wypożyczanie przedmiotów użytku osobistego i domowego,

- prace mające na celu naprawę $\mathrm{i}$ konserwacje maszyn biurowych,

- doradztwo, ksieggowość i działalność prawnicza. 
- działalność reklamową,

- pośrednictwo pracy,

- działalność dochodzeniowo-detektywistyczną oraz ochroniarska.

Cyrek (2005) wyodrębnia trzy grupy usług:

- konsumpcyjne, adresowane do osób indywidualnych;

- producenckie, wspomagające procesy produkcyjne;

- rządowe, świadczone przez państwo bezpłatnie na rzecz obywateli.

Podział sektora usług na trzy części zaproponowała także Lichniak (2010). Do części pierwszej zaliczamy transport, handel oraz usługi komunalne, druga grupa to usługi finansowe, ubezpieczenia oraz zarządzanie nieruchomościami, trzecia część to usługi wynikające $\mathrm{z}$ funkcji państwa, zaliczamy do nich: ochronę zdrowia, edukację, $\mathrm{B}+\mathrm{R}$ oraz administrację publiczną i rekreację.

Obserwując zmiany, jakie zachodzą we współczesnym świecie (np. intensywny rozwój nowoczesnych technologii, starzenie się społeczeństwa), słuszne wydaje się poszukiwanie nowych kryteriów klasyfikacji usług. Być może warto przyjrzeć się podziałowi, który wyodrębniałby następujące grupy usług:

- oparte na nowych technologiach;

- związane z doskonaleniem, podnoszeniem poziomu wiedzy i kwalifikacji (usługi edukacyjne, szkoleniowe);

- związane z panującym obecnie modelem gospodarstwa domowego (dwa plus jeden oraz coraz liczniejsze gospodarstwa jednoosobowe), wzrostem liczby pracujących kobiet i starzeniem się społeczeństwa (usługi związane z opieką nad dziećmi i osobami starszymi, usługi naprawcze, fryzjerskie, rekreacyjne, gastronomiczne, ochrona zdrowia);

- wynikające z sytuacji panującej na rynku pracy, konieczności przemieszczania się (usługi komunikacyjne, transportowe, administracyjne).

Podjęto także próbę klasyfikacji usług, uwzględniając interaktywne oddziaływanie sektorów gospodarki (rolnictwo-przemysł-usługi). Rozwój sektora rolniczego uwarunkowany jest zarówno rozwojem przemysłu, jak i rozwojem sektora usług. Obserwujemy coraz większe nasycenie procesów produkcyjnych działalnością usługową. W związku z tym, opierając się na kryterium sektoralnym, można dokonać klasyfikacji na usługi:

- sektora rolnego (wynajem, naprawa i konserwacja maszyn, usługi magazynowe, doradcze),

- przemysłowe (związane z działalnością produkcyjna),

- zaspokajające ludzkie potrzeby (administracyjne, gastronomiczne, rekreacyjne, zdrowotne, edukacyjne).

Wielość przytoczonych klasyfikacji świadczy o dużej różnorodności oferowanych usług, a dobór odpowiedniej klasyfikacji zależy od celu badania oraz dostępności danych statystycznych. 


\subsection{Tendencje rozwojowe sektora usług i ich determinanty w świetle teorii ekonomicznych}

Najpełniejszej wiedzy na temat usług dostarcza teoria trzech sektorów gospodarki, niemniej jednak najbardziej burzliwy okres rozwoju sektora usług jest utożsamiany z rozwojem społeczeństwa postindustrialnego.

Koncepcja rozwoju społeczeństwa postindustrialnego narodziła się w drugiej połowie XX w., a za jej twórców uznaje się Touraine`a i Bella (1973). Społeczeństwo postindustrialne charakteryzuje się wysokim poziomem zatrudnienia w sektorze usług oraz odchodzeniem od masowej produkcji kierowanej do anonimowego klienta do produkcji dla klienta indywidualnego.

Opierając się na teorii trójsektorowego podziału gospodarki oraz obserwacji zachodzących zmian zarówno o charakterze gospodarczym, jak i społecznym, powstało wiele koncepcji wyjaśniających zastaną rzeczywistość i określających kierunki dalszej ewolucji społeczno-gospodarczej współczesnego świata. Wśród tych koncepcji pojawiają się różne modele społeczeństwa postindustrialnego, koncepcja gospodarki usług oraz wyraźnie zarysowująca się koncepcja społeczeństwa informacyjnego.

Warto przybliżyć podejście Bella (1973), który wychodząc od trójsektorowego podziału gospodarki, wyróżnił trzy fazy rozwoju ludzkości: przedindustrialną z przewagą sektora rolniczego, górnictwa i leśnictwa, industrialna, $\mathrm{w}$ której dominuje przemysł oraz postindustrialną z wyraźną dominacją sektora usług. Według Bella ówczesne wysoko uprzemysłowione państwa kapitalistyczne wkroczyły w fazę trzecią, w której obserwujemy spadek znaczenia sektora przemysłowego na rzecz sektora usług.

Szukalski (2001, s. 26), dokonując charakterystyki społeczeństwa postindustrialnego Bella, zwraca uwagę na cztery zasadnicze czynniki.

1. W strukturze gospodarki zachodzą zmiany, w wyniku których produkcja dóbr ustępuje miejsca produkcji usług, zaczynają dominować usługi związane z prowadzeniem badań naukowych, ochroną zdrowia i zarządzaniem. Ponadto Bell dezagreguje sektor usług.

2. Odpowiednio do zachodzących przekształceń obserwujemy zmiany $\mathrm{w}$ zawodowej strukturze społeczeństwa. Bell podkreśla znaczenie zawodów akademickich, inżynieryjno-technicznych oraz wysoko wykwalifikowanych specjalistów.

3. Struktura społeczeństwa postindustrialnego jest także określana poprzez przypisywanie nadrzędnego znaczenia badaniom naukowym i wiedzy teoretycznej, politycznej i społecznej.

4. W rozwoju społeczeństwa postindustrialnego istotną rolę przywiązuje się do rozwoju ,inteligentnej technologii”, ponieważ to ona w decydującym stopniu 
wpływa na procesy społeczno-gospodarcze oraz stwarza podstawy do podejmowania decyzji opartych na gromadzeniu i przetwarzaniu informacji.

Według koncepcji społeczeństwa postindustrialnego ,sektor trzeci traktowany jest mniej jako element konstytuujący charakter społeczeństwa postprzemysłowego, a bardziej jako cecha następnego stadium rozwojowego, z racji swej dominacji w gospodarce" (Szukalski 2001, s. 28).

$\mathrm{Z}$ poglądami Bella w kwestii postępu technicznego oraz znaczenia wiedzy w dużym stopniu zgadzał się Brzeziński (1968). Wprowadzając pojęcie społeczeństwa technotronicznego, Brzeziński podobnie zresztą jak Bell wskazuje na różnice pomiędzy społeczeństwem przemysłowym. O ile w społeczeństwie przemysłowym dominuje produkcja przemysłowa i struktura gospodarcza zmienia się na korzyść tego sektora, to w społeczeństwie technotronicznym obserwujemy dominację sektora usług $\mathrm{w}$ gospodarce. Różnice obserwujemy także w stosunkach na rynku siły roboczej. W społeczeństwie technotronicznym ze względu na zmiany charakteru pracy, form jej organizacji i stylu życia zanikną socjalne jak i ekonomiczne problemy utrzymania równowagi na rynku siły roboczej. Zmiany obserwujemy także w sferze kształcenia, następuje odejście od przyjętego w społeczeństwie przemysłowym modelu równych szans dla obywateli $\mathrm{w}$ celu podniesienia ich statusu społecznego, położenia materialnego i socjalnego. W społeczeństwie technotronicznym rozwijające się ośrodki naukowe będą nasycać techniczne innowacje nowymi metodami i technikami.

Wizję społeczeństwa postindustrialnego, określanego jako społeczeństwo samoobsługowe lub samozaopatrujące się, przedstawił Skolka (1977). Podstawą sformułowania wizji społeczeństwa samoobsługowego była wysoka elastyczność cenowa popytu na usługi oraz możliwość ich substytucji przez pracę własną gospodarstw domowych. Zdaniem Skolki gospodarka samozaopatrzenia jest stadium rozwoju społeczeństwa postprzemysłowego, w którym dominuje udział usług $\mathrm{w}$ produkcie narodowym i w globalnym zatrudnieniu, przy jednoczesnej tendencji do większego zaspokajania części popytu na usługi poprzez samozaopatrywanie się gospodarstw domowych.

Zjawisko to nie należy utożsamiać jedynie jako samozaopatrywania, lecz jako wchodzenia konsumenta $\mathrm{w}$ procesy produkcyjne. Przykładem może być wpływ konsumentów na produkcję samochodu. Zamawiamy samochód określając detale, które są uwzględniane w procesie produkcji (kolor, silnik, wyposażenie). W teorii ekonomii zjawisko to jest ujmowane także jako zjawisko presumpcji (połączenie produkcji z konsumpcją). Interesujące przemyślenia w tym zakresie przedstawia Toffler $(2001,2007)$. Autor w swych pracach odwołuje się do pojęcia technologii, a historię ludzkości rozpatruje w kontekście trzech następujących po sobie fal technologicznych. Fala pierwsza określana jako agrarna według Tofflera była związana z pojawianiem się wynalazków i umiejętności, mających związek z rolnictwem i osiadłym trybem życia. Fala druga - przemy- 
słowa - to związane z wynalazkiem druku i maszyny parowej powstanie industrializmu. To tej fali zawdzięczamy między innymi pojawienie się stali, elektryczności, środków transportu. Fala trzecia, której według Tofflera obecnie doświadczamy, jest bezpośrednio związana z powstaniem nowych technologii, umożliwiających nieograniczoną komunikację między jednostkami dzięki rozwojowi usług i odejściu od masowej produkcji. Autor przekonuje, że pomimo różnych wstrząsów i przewrotów, które pojawiają się zwłaszcza przy przybieraniu trzeciej fali, ludzkość nie wyniszczy się całkowicie. Zakłada także, że zachodzące zmiany dotyczą wielu aspektów życia, wywołując kolejne fale przemian, a zdrowa i upragniona przyszłość nie jest w tym modelu osiagalna. Toffler w swych rozważaniach wysunął tezę o zachodzeniu na siebie różnych form i faz cywilizacji. Z tezy tej wyciagnął wniosek o nieprzewidywalności procesów historycznych, podkreślał jednocześnie, że przewidywanie może mieć miejsce w ramach jednej określonej fali. W sytuacji, gdy dochodzi do zderzenia różnych fal i żadna nie góruje nad pozostałymi, wszelkie przewidywania tracą sens.

Przedstawione koncepcje powstały na podstawie obserwacji strukturalnych zmian gospodarek państw wysoko uprzemysłowionych. Nieco inną koncepcją zmian strukturalnych określaną jako ,gospodarka usług” przedstawia Giarini (1986). Gospodarka usług jest rozumiana jako stan gospodarki, w którym usługi poprzez udział w zatrudnieniu i produkcie narodowym dominują nad pozostałymi sektorami. Uważa się także, że jeżeli przynajmniej połowa wszystkich kosztów, jakie powstają przy produkcji dóbr i usług, sprowadza się do nakładów związanych z funkcjonowaniem i działalnością usługową, to taki stan gospodarki można określić jako gospodarkę usług. Giarini, posługując się kryterium funkcji, jakie spełniają usługi zarówno w sektorze usług, jak i pozostałych sektorach, wyróżnił pięć cech gospodarki usług:

1) dominacja funkcji usługowych w przedsiębiorstwach oraz gospodarce jako całości;

2) dochodzi do zintegrowania funkcji usługowych, w wyniku czego powstaje system, w którym w rosnącym stopniu produkty i wyroby nie mogą być oferowane bez infrastruktury usługowej;

3) wraz ze wzrostem możliwości dla inicjatyw i działalności podmiotów gospodarczych wzrasta ryzyko;

4) powstawanie nowych technik i technologii wpływa na zmianę procesu produkcji dóbr i na proces świadczenia usług;

5) wzrost znaczenia pozamaterialnych wartości w życiu społecznym powoduje zwiększenie znaczenia wiedzy, ochrony zdrowia i zagospodarowania czasu wolnego.

Ze względu na szybki rozwój technik informacyjnych pojawiła się koncepcja podziału gospodarki na cztery sektory. Próby definiowania nowego sektora nazywanego sektorem informacyjnym oraz określenia jego miejsca i znaczenia 
w strukturze gospodarki podjęli Porat (1977) i Dostal (1988). Porat, opierając się na kryterium charakteru działalności zatrudnionych, proponował wyłączenie z trójsektorowego modelu gospodarki zatrudnionych, którzy są związani z działalnością informacyjną. Przedstawił podział gospodarki na cztery sektory, obejmujące: przemysł, rolnictwo, usługi oraz czwarty sektor informacyjny. Koncepcję podziału gospodarki na cztery sektory popierał Dostal, twierdząc, że taki podział gospodarki może lepiej opisać rozwój zatrudnienia niż podział tradycyjny. Czwarty sektor gospodarki miałby być wydzielany z dotychczasowych sektorów i definiowany jako „całokształt działalności gospodarczej służącej produkcji, użytkowaniu, ochronie, gromadzeniu, przechowywaniu, przekazywaniu i przesyłaniu informacji, jej kontroli, monitorowania i zarządzania, w szczególności jej handlu" (Dziuba 2010, s. 23).

Autor proponuje, aby w skład sektora informacyjnego wchodziły: edukacja, działalność badawczo-rozwojowa, przemysł papierniczy i wydawniczy, produkcja komputerów i oprogramowanie, poczta i telekomunikacja, usługi związane z radiem i telewizja, działalność kulturalna, rekreacyjna i oświatowa, reklama, usługi biurowe, tzw. użytkownicy i ,producenci informacji” w zakresie finansów, handlu, obsługi nieruchomościami, administracji oraz wiele innych usług opartych na informacji. Intensywny rozwój technologii informatycznych i komunikacyjnych wpłynął na szeroki dostęp do informacji, ułatwiając między innymi podejmowanie decyzji ekonomicznych. Wiele przesłanek świadczy o dużym znaczeniu w rozwoju gospodarczym sektora informacyjnego, jak dotąd brak jest szeroko akceptowanej metodologii jego wyodrębniania z pozostałych sektorów. Analizując gospodarki krajów wysoko rozwiniętych, brak jest informacji świadczących o podziale gospodarki na cztery sektory. Pomimo dokonujących się w gospodarce zmian, coraz większego znaczenia informacji i wiedzy podział gospodarki na trzy sektory pozostaje nadal aktualny.

$\mathrm{Na}$ wyłanianie się społeczeństwa pokapitalistycznego, zwanego inaczej społeczeństwem wiedzy i kapitalizmu informacji, zwraca także uwage Drucker (1999). Zgodnie z definicją OECD i Banku Światowego ,gospodarka oparta na wiedzy jest gospodarka, w której wiedza jest tworzona, przyswajana, przekazywana i efektywnie wykorzystywana przez przedsiębiorstwa, indywidualne osoby i społeczności, sprzyjające, szybkiemu rozwojowi gospodarki i społeczeństwa" (Gospodarka oparta na wiedzy, 2003, s. 195, 326).

Analizując rozwój sektora usług w Polsce, należy stwierdzić, że kształtował się on pod wpływem zachodzących zmian w gospodarce. Po II wojnie światowej państwa dotknięte zniszczeniami wojennymi nastawione były początkowo na zaspokajanie potrzeb materialnych, na rozwój produkcji i rolnictwa. Sektor usług nie pełnił $\mathrm{w}$ tym okresie istotnego znaczenia $\mathrm{w}$ rozwoju gospodarczym kraju, większego znaczenia zaczął nabierać w latach siedemdziesiątych. Zauważalny stał się wzrost zapotrzebowania społeczeństwa na różnego rodzaju usługi, 
między innymi: zdrowotne, edukacyjne, kulturowe. Dynamiczny rozwój sektora zaobserwowany został $\mathrm{w}$ latach dziewięćdziesiątych wraz $\mathrm{z}$ rozwojem usług telekomunikacyjnych i informatycznych, wzrastał wówczas popyt na wytwarzanie, przetwarzanie i przesyłanie informacji (Stefaniak 2007).

Struktura sektora usług w gospodarkach poszczególnych państw jest wynikiem zmian charakteru usług w kolejnych etapach rozwoju społeczno-gospodarczego. Poszczególne rodzaje usług charakteryzują się odmienną dynamiką na różnych etapach rozwoju. Flejterski, Panasiuk, Perenc, Rosa (2005, s. 36) wyróżniają cztery fazy rozwoju sektora usług:

1. Faza pierwsza, w której dominują usługi nie wymagające wysokich kwalifikacji zawodowych.

2. Faza wzrostowa, w której obserwujemy rozwój usług wymagających kwalifikacji.

3. Faza obsługi przemysłu i wzrostu konsumpcji usług, w której równocześnie dochodzi do rozwoju działalności usługowej związanej z obsługą przemysłu, np. usługi ubezpieczeniowe, transportowe i usług o charakterze konsumpcyjnym.

4. Faza rozwoju usług opartych na wysokich technologiach.

Wejście w czwartą fazę rozwoju sektora usług obserwujemy jedynie wśród państw wysoko rozwiniętych.

Na pewne tendencje cechujące współczesny rozwój sektora usług wskazują także Kuczewska (2007) i Słomińska (2009). Należy zwrócić uwagę na:

- dość szybkie tempo rozwoju tzw. usług nowych (informacyjnych, biznesowych, pośrednictwa finansowego) w porównaniu $\mathrm{z}$ usługami tradycyjnymi (transport, handel);

- coraz częstsze wykorzystywanie najnowszych technologii, zwłaszcza w bankowości, telekomunikacji, ubezpieczeniach;

- rozwój działalności związanej z zagospodarowaniem czasu wolnego, ochroną zdrowia i ochroną środowiska;

- stworzenie obszaru gospodarki tworzącego bazę dla społeczeństwa informacyjnego i związanego z usługami komputerowymi i telekomunikacją.

Pomimo panującego poglądu, że intensywny rozwój sektora usług jest prawidłowością ekonomiczną, w literaturze spotykamy się z pewnego rodzaju krytyką tego procesu. Niejednokrotnie podkreślane są granice ekspansji sektora usług w krajach najwyżej rozwiniętych, zwraca się także uwagę na niższe tempo wzrostu wydajności pracy w usługach, które w powiązaniu ze wzrostem płac skutkuje wzrostem cen i ograniczeniem konsumpcji. Ze względu na nasycenie popytu konsumpcyjnego uwalniana jest siła robocza z sektora usług, co w dalszej konsekwencji może być przyczyną bezrobocia. Uwzględniając te czynniki, Grubel i Walker (1993, s. 232-265) wskazują na potrzebę interwencji państwa w kierunku zapobiegania nadmiernemu rozwojowi sektora usług. Podejście takie 
zaprzecza dążeniu do tworzenia nowych miejsc pracy w sektorze usług, stanowiących warunek sprawnego funkcjonowania pozostałych dwóch sektorów i ograniczania bezrobocia.

Sektor usług obejmuje bardzo szeroki obszar różnorodnych dziedzin, w związku z tym na jego rozwój wpływają różne czynniki. Rozwój sektora usług jest uwarunkowany determinantami, które możemy podzielić na determinanty o charakterze wewnętrznym i determinanty zewnętrzne. Uwarunkowania wewnętrzne wynikają ze specyfiki działalności usługowej. Charakterystykami wyjaśniającymi międzysektorowe przepływy siły roboczej są: wysoka elastyczność dochodowa popytu, ograniczone oddziaływanie postępu technologicznego, wolniejsza niż w przemyśle substytucja pracy przez kapitał, znacznie niższe korzyści skali, wysokie wykorzystanie wykwalifikowanej siły roboczej i niższe tempo wzrostu jej jakości niż w przemyśle, szybszy spadek liczby przepracowanych godzin na osobę oraz relatywny wzrost płac względem kapitału (Cyrek 2012, s. 37-40 za Fuchs: 1965, 1968). Do determinant zewnętrznych oddziałujących na dynamikę rozwoju sektora usług oraz ich wewnętrzną strukturę zaliczamy zmiany o charakterze demograficzno-społecznym, ogólnogospodarcze, technologiczne i polityczne. Wymienione uwarunkowania wpływają na dynamikę rozwoju sektora usług i zmiany ich wewnętrznej struktury, ponadto kształtują cechy świadczenia usługowego, podlegającego w coraz większym stopniu umiędzynarodowieniu, standaryzacji i specjalizacji oraz różnicowaniu i indywidualizacji.

Do zmian o charakterze demograficzno-społecznym wpływających na rozwój usług zaliczamy następujące zjawiska (Daszkowska 1998; Olearnik, Styś 1989; Flejterski i in. 2005; Rudawska 2009; Cyrek 2012):

- starzenie się społeczeństwa - wydłuża się średnia długości życia, wzrasta zapotrzebowanie na usługi medyczne i paramedyczne oraz usługi związane z zagospodarowaniem wolnego czasu;

- wzrost migracji ludności, wpływający na rozwój regionów oraz rozwój usług związanych z infrastrukturą techniczną i społeczną;

- wzrost aktywności zawodowej kobiet, wpływający na rozwój usług związanych z opieką nad dziećmi oraz usług gastronomicznych,

- poprawa jakości życia i wzrost zamożności społeczeństwa umożliwia dostęp do usług o charakterze kulturalno-rozrywkowym oraz daje możliwość korzystania $\mathrm{z}$ usług handlu detalicznego czy handlu nieruchomościami;

- swoboda przemieszczania się i wykształcenie bardziej wyrafinowanych potrzeb wymagające korzystania z usług na wysokim poziomie,

- wzrost aspiracji ludzi oraz postęp cywilizacyjny kreuje popyt na usługi edukacyjne i kulturalne.

Podkreślając w rozwoju usług znaczenie społecznych uwarunkowań, należy zauważyć zmiany w zachowaniu konsumentów o podłożu kulturowo-aksjologicznym. 
Uważa się, że obecnie zakres relacji usługowych określają (por. Flejterski, Panasiuk, Perenc, Rosa 2005, s. 61-62):

- indywidualizm;

- prywatyzacja i postawy przedsiębiorcze i samorządne;

- nowe podejście do wykonywanej pracy - identyfikacja z przedsiębiorstwem, zatarcie granic między czasem przeznaczonym na pracę, wypoczynek i kształcenie;

- etyka przejawiająca się dążeniem do odpowiedzialności, zaufania, społecznej akceptacji oraz partnerstwie producenta i konsumenta;

- orientacja ekologiczna i zdrowy styl życia.

Wśród zmian ogólnogospodarczych i technologicznych wpływających na rozwój usług najczęściej wymienia się (Kłosiński 1997; Daszkowska 1998; Olearnik, Styś 1989; Flejterski 2005 i in.; Rudawska 2005; Cyrek 2012):

- zmianę charakteru gospodarki w kierunku nietrwałości, stwarzającą potrzebę rozwoju usług edukacyjnych;

- dążenie do wzrostu wydajności i skracania czasu pracy, wpływające na rozwój usług związanych z zagospodarowaniem czasu wolnego;

- globalizację gospodarki, wiążącą się ze wzrastającym strumieniem dóbr, osób, płatności oraz informacji, prowadzącą do rozwoju wyspecjalizowanych instytucjonalnych form usługowych;

- postęp technologiczny w zakresie komunikacji i przemieszczania się powoduje rozwój usług turystycznych i transportowych;

- zawiłość przepisów prawnych oraz wąska specjalizacja niektórych dziedzin gospodarki wpływa na rozwój usług doradczych w zakresie prawa i finansów;

- znaczne zróżnicowanie oraz postęp technologiczny w sferze usług bankowych i ubezpieczeniowych prowadzi do korzystania $z$ usług organizacji zabezpieczających płynność finansową oraz zapewniających bezpieczeństwo finansowe,

- intensywny rozwój produkcji i użytkowania dóbr materialnych oznaczające rozwój usług komplementarnych (transportowych, ubezpieczeniowych, bankowych) składających się na produkt rozszerzony lub pakiet usług logistycznych,

- pogłębianie się społecznego i technicznego podziału pracy (coraz silniejsze uzależnienie od usług świadczonych przez inne osoby zarówno w sferze pracy jak i konsumpcji) prowadzi do rozwoju wyspecjalizowanych firm,

- umiędzynarodowienie rynku, zmiana modelu prowadzenia biznesu prowadzi do korzystania z usług firm zajmujących się badaniem rynku, rekrutacją pracowników, pracami badawczo-rozwojowymi oraz marketingiem,

unowocześnienie sektora usług prowadzące do wzrostu wydajności pracy, powstawania nowych rodzajów usług, poprawy jakości świadczonych usług oraz przyspieszające substytucję dóbr materialnych usługami.

Do uwarunkowań rozwoju usług o charakterze zmian politycznych, zaliczanych do czynników subiektywnych lub quasi-subiektywnych, należą (Olearnik, Styś 1989, s. 25-29; Daszkowska 1998, s. 77-79; Flejterski i in. 2005, s.18-19, 59-60): 
- postępująca liberalizacja rynków, przyczyniająca się wzrostu konkurencji i dostępności usług;

- rozbudowa struktur administracyjnych;

-wzrost interwencjonizmu państwowego i regulacji, wpływających na rozwój usług specjalistów - analityków w zakresie rozwiązań prawnych i sporządzania instytucjonalno-prawnie wymaganej dokumentacji;

- procesy integracyjne, w tym przebiegające w ramach Unii Europejskiej, skutkujące wprowadzaniem zasady swobody przepływu usług;

- wzrastające publiczne wsparcie finansowe dla rozwoju usług społecznych.

Różnorodność determinant rozwoju sektora usług świadczy o złożoności problemu.

Przedstawienie genezy sektora usług, zapoznanie z pojęciem usług oraz ich specyficznymi cechami i funkcjami stwarza podłoże do określenia wpływu koniunktury na sektor usług.

\subsection{Zmiany koniunktury gospodarczej a sektor usług}

Koniunktura gospodarcza to wszelkie zmiany aktywności gospodarczej, przejawiające się $\mathrm{w}$ zmianach podstawowych wskaźników ekonomicznych. Wskaźniki te na ogół mają charakter agregatowy i określają kondycję gospodarki. Do najważniejszych zaliczamy PKB, PNB, wskaźniki bezrobocia, inflacji. Koniunktura według Nowej encyklopedii powszechnej PWN (2004) to całokształt wskaźników życia gospodarczego, charakteryzujących stan gospodarki danego kraju lub rynku pozwalających ocenić tendencje rozwojowe. Badania koniunktury przeprowadza się w celu umożliwienia podjęcia kroków zaradczych i dostosowania decyzji ekonomicznych do nadchodzacych przemian gospodarczych. Okresowe zmiany poziomu aktywności gospodarczej określa się mianem cyklu koniunkturalnego (por. Milewski, Kwiatkowski 2005). Według Burnsa i Mitchella (por. Barczyk, Kowalczyk 1993 s. 11) „cykle koniunkturalne są rodzajem wahań, występujących w agregatach przedstawiających działalność gospodarczą narodów, organizujących swoją produkcję przeważnie w przedsiębiorstwach; cykle składają się z okresów ekspansji, występujących w tym samym czasie $\mathrm{w}$ wielu dziedzinach gospodarczych, następujących po nich równie generalnych kryzysach, zastojach oraz ożywieniach, które łączą się z fazą ekspansji cyklu następnego".

W cyklu koniunkturalnym przeważnie wyróżnia się cztery fazy: kryzys, depresję, ożywienie i rozkwit. Cechą charakterystyczną fazy kryzysu jest nadprodukcja, czyli przewaga podaży w porównaniu z efektem popytowym. Następuje spadek cen, spada dochód narodowy i wzrasta bezrobocie. Faza depresji określana także jako faza zastoju cechuje się względną stabilizacją gospodarki na 
obniżonym poziomie. W momencie wzrostu poszczególnych wskaźników określających aktywność gospodarczą mówimy o fazie ożywienia (stopniowy wzrost produkcji i zatrudnienia, wzrost zysków i dochodów ludności). Po osiagnięciu przez wskaźniki odpowiednio wysokich poziomów, wyższych niż w poprzednim cyklu, zaczyna się faza rozkwitu (szybki wzrost produkcji, zatrudnienia, zysków i dochodów ludności). Obecnie w literaturze ekonomicznej wyodrębnia się dwie fazy cyklu: fazę spadkową łączącą fazy kryzysu i depresji oraz fazę wzrostową łączącą fazy ożywienia i rozkwitu (por. Milewski, Kwiatkowski 2005). Podejście takie jest związane z pewnego rodzaju zmianą samego przebiegu cyklu. Uważa się, że faza spadkowa nie musi charakteryzować się absolutnym spadkiem poszczególnych wskaźników działalności gospodarczej, ponieważ jej objawami może być brak wzrostu lub zwolnienie jego tempa. Zmniejszenie amplitudy wahań, złagodzenie przebiegu cyklu jest wynikiem przemian gospodarki rynkowej.

Cykle koniunkturalne charakteryzowane są przez pewne właściwości określane także cechami morfologicznymi. Do najważniejszych cech opisujących morfologię wahań koniunkturalnych oraz cykli zaliczamy (por. Barczyk, Kowalczyk 1993):

- długość, która jest wyznaczana przez okresy występujące między punktami zwrotnymi;

- częstotliwość określająca, ile cykli lub jaka część cyklu występuje w przyjętej jednostce czasu;

- amplitudę będącą różnicą między skrajnymi wartościami pewnych elementów występujących w danym okresie,

- intensywność oznaczającą siłę tendencji zwyżkowych lub zniżkowych występujących w poszczególnych fazach;

- symetryczność (asymetryczność) informującą o relacji pomiędzy amplitudą poszczególnych faz oraz o zależnościach w zakresie ich długości;

- strukturę przedstawiającą układ oraz wzajemne relacje między poszczególnymi elementami składającymi się na proces cykliczny.

Uważa się, że sektor usług jest mniej wrażliwy na koniunkturę niż pozostałe sektory gospodarki. Nie wszystkie jednak subsektory usług zachowują się jednakowo w poszczególnych fazach koniunktury. Za wrażliwe koniunkturalnie uznaje się branże zaliczane do usług materialnych, które są komplementarne względem sektorów produkcyjnych (handel, transport).

Usługi nie ulegają wahaniom koniunkturalnym w takim samym stopniu jak sfera produkcji materialnej, ponieważ (Szukalski 2001, s. 157):

- odporność na wahania koniunktury większości usług o charakterze niematerialnym wynika $\mathrm{z}$ ich istoty;

- niewrażliwość wielu usług niematerialnych na wahania koniunktury wynika $\mathrm{z}$ instytucjonalnych form ich świadczenia (część usług oferowana jest przez państwo w formie nieodpłatnych lub częściowo odpłatnych usług niekomercyjnych); 
- mniejsza koncentracja kapitału i produkcji w sektorze usług niż w przemyśle oraz przewaga pracujących na własny rachunek wpływa na większą stabilizację zatrudnienia;

- stabilizująco na koniunkturalne zmiany zatrudnienia wpływa wysoki udział urzędników;

- usługi kierowane są głównie na zaspokojenie popytu rynku wewnętrznego, brak więc narażenia na fluktuacje koniunkturalne ze strony rynków światowych.

Podczas rozważań nad koniunkturą sektora usług nasuwa się pytanie, jaki jest wpływ wahań koniunkturalnych na tempo strukturalnych przekształceń, w których sektor III oraz poszczególne jego branże zmieniają udział w globalnej produkcji i zatrudnieniu.

Według Szukalskiego (2001, s. 169) intensywność zmian strukturalnych wyraźnie rośnie w okresach znacznych fluktuacji koniunkturalnych. Nie wszystkie branże jednak podlegają wahaniom w jednakowym tempie. Dokonując porównania tempa wzrostu wrażliwości koniunkturalnej danej branży, można ocenić strukturalne przekształcenie. Teoretycznie istnieją cztery rodzaje zmian z różnymi efektami strukturalnymi:

1. Branże o wysokiej stopie wzrostu i dużej wrażliwość koniunkturalnej zwiększają swoje udziały w okresie rozkwitu.

2. Branże o wysokiej stopie wzrostu i odporne koniunkturalnie silnie zwiększają swój udział w okresie recesji.

3. Branże o niskiej stopie wzrostu i wrażliwe koniunkturalne znaczne straty ponoszą $\mathrm{w}$ zakresie swojego udziału $\mathrm{w}$ strukturze $\mathrm{w}$ okresie recesji, a w fazie koniunktury niewiele zyskuja.

4. Branże o niskiej stopie wzrostu oraz odporne koniunkturalnie znaczne straty ponoszą w okresie boomu.

Obserwacje tempa zmian struktury gospodarczej z punktu widzenia koniunkturalnego rozwoju gospodarczego pozwalają zauważyć wzrost udziału sektora usług $\mathrm{w}$ okresach recesji gospodarczej bez spadku w fazie rozkwitu. Zachowanie takie można tłumaczyć tym, że sektor usług bardzo intensywnie wchłania siłę roboczą w okresie recesji, będąc pewnego rodzaju stabilizatorem rynku pracy, przy spadku zatrudnienia w pozostałych sektorach.

\subsection{Uwagi końcowe}

Rozważania w niniejszym rozdziale koncentrowały się wokół problemów związanych z trójsektorowym podziałem gospodarki. W wyniku szczegółowej analizy poglądów wielu autorów oraz własnych badań nasuwają się następujące wnioski i spostrzeżenia: 
1. Podział gospodarki na trzy sektory stanowi podstawę badań struktury gospodarczej i zmian strukturalnych, jakie w niej zachodzą.

2. Następuje systematyczny rozwój sektor usług. Obserwuje się coraz większe znaczenie i wykorzystanie sektora usług przez sektor wytwórczy.

3. Podział gospodarki na trzy sektory nie jest rozłączny, pomiędzy sektorami występują wzajemne powiązania, funkcjonowanie sektora rolniczego i przemysłowego jest uzależnione od sektora usług.

4. Rozwój nowoczesnych usług opartych na wiedzy (finansowych, telekomunikacyjnych) wpływa na wzrost produktywności sektora usługowego oraz zmiany zatrudnienia $\mathrm{w}$ gospodarce.

5. Teoria trzech sektorów z powodu analiz krytycznych nie straciła znaczenia i dalej stanowi podstawy do oceny rozwoju gospodarki.

6. Badania zachodzących zmian strukturalnych w ujęciu trójsektorowym doprowadziły do zdefiniowania trzech procesów charakteryzujących zmiany strukturalne, występujących w większości krajów rozwiniętych: deagraryzacji, deindustralizacji i tertiaryzacji.

W badaniach nad rozwojem sektora usług niejednokrotnie spotykamy się ze stwierdzeniem, że dynamiczny rozwój sektora usług będzie wpływał na zmniejszanie i zacieranie granic pomiędzy trzema tradycyjnymi sektorami gospodarki. Należy jednak zauważyć, że pomiędzy sektorami występują wzajemne powiązania, zależności i oddziaływania, sektor rolniczy i przemysłowy nie może funkcjonować bez usług i odwrotnie sektor usług nie będzie funkcjonował bez pozostałych sektorów gospodarki. W związku z tym obserwujemy proces przenikania się produkcji i usług. $Z$ teorii trzech sektorów wynika, że przekształcenia struktury gospodarczej są warunkiem rozwoju gospodarczego. Przekształcenia te nie są jednak dowolne, przebiegają w różnym tempie, ale zgodnie $\mathrm{z}$ określonymi prawidłowościami. W związku z tym sektor usług będzie się nadal dynamicznie rozwijał, tworząc nowe rodzaje usług. Dojdzie nie tyle do zatarcia różnic co do jeszcze ściślejszego powiązania pomiędzy sektorami, ich wzajemnego oddziaływania na siebie. Sektory rolny i przemysłowy będą korzystały w coraz większej mierze z nowych rodzajów usług, zwiększających zarówno efektywność produkcji, jak i kreujących popyt na produkty. 


\section{METODY STATYSTYCZNE STOSOWANE W ANALIZIE ROZWOJU USŁUG}

\subsection{Uwagi wstępne}

Ocena rynku usług może być dokonana różnymi metodami. Najprostszym sposobem jest analiza oparta na wskaźnikach ekonomicznych, uwzględniających udział sektora usług w całej gospodarce. Innym sposobem jest określenie pozycji sektora usług danego kraju względem innych państw. Oceny rynku usług można także dokonać, opierając się na wielkościach korzyści, wynikających $\mathrm{z}$ jego rozwoju dla konsumenta. Złożoność zjawisk społeczno-gospodarczych, wpływających na rozwój sektora usług oraz poszczególnych regionów, wymaga wykorzystania różnych metod umożliwiających określenie poziomu tego zjawiska. Przeprowadzenie pogłębionych analiz sektora usług spowodowało zwrócenie uwagi na metody statystyczne, które umożliwiają przetwarzanie danych liczbowych charakteryzujących sektor usług $\mathrm{w}$ informacje ekonomiczne przydatne w zarządzaniu gospodarką.

W analizie sektora usług podjęto próbę wykorzystania wielu różnych wskaźników i metod. Począwszy od najprostszych, do których należy zaliczyć wskaźniki struktury i wskaźniki natężenia a skończywszy na metodach prognostycznych. Starano się zwrócić uwagę na istotę modelowania statystycznego. Do określenia kierunku i intensywności zmian poziomu zjawisk w czasie posłużono się złożonymi indeksami dynamiki.

Na rozwój sektora usług wpływa wiele czynników i niejednokrotnie trudno jest wybrać te najbardziej istotne. Wzrastające możliwości gromadzenia danych sprawiają że do badania sektora usług można wykorzystać bardzo dużą liczbę zmiennych. Analizowanie zjawisk czy zachodzących procesów gospodarczych z udziałem dużej liczby zmiennych jest złożone zarówno ze względu na liczbę, jak i powiązania między zmiennymi. W takich przypadkach pojawia się konieczność przekształcenia dużej liczby zmiennych rzeczywistych w mniejszą liczbę zmiennych koncepcyjnych. Bardzo pomocną w takich sytuacjach okazuje się metoda analizy czynnikowej. Analiza czynnikowa jest metodą badania struktury obserwacji wielowymiarowych, która służy do badania wewnętrznych za- 
leżności, jakie zachodzą w zbiorze zmiennych opisujących to określone zjawisko i jest pomocna w ocenie sektor usług. Metodami, służącymi do klasyfikacji obiektów opisywanych przez wiele cech, są metody taksonomiczne. Metody porządkowania liniowego obiektów polegają na porządkowaniu elementów badanego zbioru na podstawie zdefiniowanego nadrzędnego kryterium ich oceny oraz wartości wybranych w tym celu zmiennych diagnostycznych. Czynność porządkowania sprowadza się do konstrukcji teoretycznego wskaźnika syntetycznego dla analizowanych obiektów, pełniącego rolę miernika. Szczegółową uwagę poświęcono bardziej zaawansowanym metodom, które mogą służyć do określania poziomu rozwoju społeczno-gospodarczego jednostek terytorialnych. Do metod tych można zaliczyć także skalowanie wielowymiarowe, miary Hellwiga i Perkala oraz metodę Wintersa. Zastosowanie tych metod w analizie sektora usług pozwoli wszechstronnie zbadać znaczenie najważniejszego sektora polskiej gospodarki.

\subsection{Pomiar statystyczny}

W naukach ekonomiczno-społecznych pomiar jest procesem złożonym. Istnieje wiele zjawisk w tym obszarze, które nie są bezpośrednio obserwowane, np. pomiar dochodów wydatków, pomiar rozwoju regionu, pomiar postaw, opinii, preferencji, poglądów. W dużej mierze wynika to $\mathrm{z}$ jakościowego charakteru uzyskiwanych informacji (w porównaniu z ilościowym charakterem wcześniej wymienionych informacji).

W przytaczanej definicji pomiaru wygodne jest przyjąć pewne oznaczenia (Domański, Pruska, Wagner, 1998, s. 36-37). Oznaczmy przez $J=\left\{J_{1}, J_{2}, \ldots, J_{n}\right\}$ zbiór $n$ jednostek (przedmiotów, rzeczy, indywiduów, osobników, zdarzeń, procesów, zjawisk), przez $W$ pewną wyróżnioną właściwość tych jednostek. Właściwość $W$ może być kwantyfikowana, oznacza to, że jednostkom przyporządkowuje się według określonych zasad wartości liczbowe. Pozwala to rozróżnić jednostki pomiędzy sobą oraz prowadzić ich badanie od strony empirycznej. Między jednostkami i wartościami liczbowymi zachodzą różne relacje dwuczłonowe. Oznacza to uwzględnienie takiego zbioru relacji $R$, który byłby właściwy dla stosunków, które zachodzą między jednostkami, oraz zbioru relacji $R^{T}$ wielkości charakteryzujących te związki. Wskazana odpowiedniość między zbiorem jednostek $J$ i relacji $R$ oraz zadanym zbiorem liczbowym i relacji $R^{T}$ prowadzi do określenia dwóch systemów, wyrażonych następująco:

$E=\langle J, R\rangle$ - system empiryczny, w którym zbiór $R$ wyraża relacje zachodzące pomiędzy jednostkami ze zbioru $J$; 
$M=\langle A, R\rangle$ - system matematyczny, w którym zbiór $R$ wyraża relacje zachodzące pomiędzy liczbami rzeczywistymi ze zbioru $A$.

Wymienione systemy są związane operacją odwzorowania, będącą funkcją $f$, która przyporządkowuje wartości liczbowe jednostkom ze zbioru $J$ oraz zachowuje odpowiedniość pomiędzy jednostkami tych systemów. Przyjęte oznaczenia pozwalają wprowadzić pojęcie pomiaru, któremu podlega każda jednostka ze względu na badaną właściwość $W$. Pomiarem właściwości $W$ w systemie $E$ nazywamy funkcję $f$, która każdej jednostce ze zbioru $J$ przyporządkowuje - zgodnie z przyjętymi regułami, w wyniku pewnych czynności w danych standardowych warunkach - wartość liczbową ze zbioru $A$ w taki sposób, że pomiędzy systemami $E$ i $M$ zachodzi odwzorowanie homomorficzne.

Według Pawłowskiego (1969, s. 54) oraz Choynowskiego (1971, s. 17) przez pomiar rozumie się przyporządkowanie liczb obiektom zgodnie z określonymi regułami $\mathrm{w}$ taki sposób, aby liczby odzwierciedlały relacje zachodzące między obiektami.

Celem pomiaru jest takie przedstawienie treści dokonanych obserwacji na jednostkach, aby symbole były związane ze sobą tak samo, jak są lub mogą być połączone ze sobą analizowane jednostki, zdarzenia, czy zjawiska opisujące te pojęcia.

W teorii pomiaru wyróżnia się dwa rodzaje pomiaru, pomiar bezpośredni nazywany inaczej pierwotnym oraz pomiar pośredni określany także jako wtórny.

Pomiarem bezpośrednim (pośrednim) nazywamy taki pomiar, który przyporządkowuje wartości liczbowe właściwości $W$ bez udziału (będących funkcją) innych właściwości.

Zakres pomiaru jest określony jego skalą, która wyraża wzajemną odpowiedniość między systemami empirycznym $E$ i matematycznym $M$ w aspekcie przeprowadzonego pomiaru właściwości $W$ na jednostkach ze zbioru $J$. Taką odpowiedniość ujmuje skala pomiaru, należąca do podstawowych pojęć teorii pomiaru.

Skalą pomiaru nazywamy uporządkowaną czwórkę $U=\langle J, G, A, F\rangle$, gdzie:

$J=\left\{J_{1}, J_{2}, \ldots, J_{n}\right\}-$ zbiór $n$ wyróżnionych jednostek,

$A$ - zbiór liczb rzeczywistych, w szczególności przedział liczbowy,

$G$ - zbiór funkcji odwzorowujących jednostki ze zbioru $J$ w zbiór $A$, czyli: jeżeli $g \in G$ to $g: J \rightarrow A$,

$F$-zbiór funkcji odwzorowujących liczby ze zbioru $A$ w zbiór $A$, czyli: jeżeli $f \in F$ to $f: A \rightarrow A$, a ponadto superpozycja funkcji ze zbioru $F$ także jest funkcją ze zbioru $F$ (Domański, Pruska, Wagner 1998, s. 37).

Za pomocą reguł pomiaru wyróżnia się także jego poziomy określane inaczej jako kategorie lub warianty, które różnią się właściwościami formalnymi systemów matematycznych, które można stosować do danych pomiarowych, 
rodzajem dopuszczalnych przekształceń danych oraz rodzajem działań formalnych mających sens w tych systemach.

$\mathrm{Z}$ kolei różnym poziomom pomiaru odpowiadają różne rodzaje skal pomiaru. W teorii pomiaru rozróżnia się cztery podstawowe skale wprowadzone przez Stevensa (1959 za Walesiak, Gatnar 2009, s. 64). Wyróżniamy skale: nominalną, porządkową, przedziałową i stosunkową. Wiążą się one bezpośrednio z postaciami funkcji $f$, jakie są dopuszczalne następująco:

- skala nominalna - $f$ jest wzajemnie jednoznaczna, to znaczy, że różnym wartościom zmiennej niezależnej odpowiadają różne wartości zmiennej zależnej;

- skala porządkowa (rangowa) - $f$ jest ściśle monotonicznie rosnąca, czyli wraz ze wzrostem wartości zmiennej niezależnej rosną wartości zmiennej zależnej;

- skala przedziałowa (interwałowa) - $f(x)=b x+a$, przy czym $b>0$, a jej wartości i argumenty należą do zbioru liczb rzeczywistych;

- skala stosunkowa (ilorazowa) - $f(x)=b x$, przy czym $b>0$, a jej wartości i argumenty należą do zbioru liczb rzeczywistych dodatnich.

Skale pomiaru są uporządkowane od najsłabszej do najmocniejszej: nominalna, porządkowa, przedziałowa, stosunkowa. Skale przedziałową i stosunkową zalicza się do skal metrycznych, natomiast nominalną i porządkową do niemetrycznych.

\subsection{Modele statystyczne}

Pojęcie modelu jest wieloznaczne, w literaturze spotykamy wiele jego wykładni. Model to pewnego rodzaju schematyczne uproszczenie, pomijające nieistotne aspekty w celu wyjaśnienia wewnętrznego działania, formy lub konstrukcji bardziej skomplikowanego mechanizmu (por. Klein 1982). Jest uproszczonym odwzorowaniem rzeczywistości, przedstawia wyodrębnione, obiektywnie istniejące relacje, jest zestawieniem użytecznych reguł, które pozwalają upodobniać zachowanie i własności przedstawionej rzeczywistości, adekwatnie odtwarza badane obiekty, zjawiska lub procesy (por. Ostasiewicz 1998). W pracy podjęto próby wykorzystania modeli statystycznych do prognozowania udziału wartości dodanej brutto w sektorze usług.

Na potrzeby rozprawy przyjmuje się następującą definicję modelu.

Modelem danego rzeczywistego obiektu nazywa się układ, dający się wyobrazić lub materialnie zrealizować, który odzwierciedlając lub odtwarzając obiekt, zdolny jest zastępować go tak, że jego badanie dostarcza nowych nadających się do dalszego sprawdzania informacji o obiekcie (por. Domański, Pruska, Wagner 1998, s. 56-58). 
Konstrukcja modelu przyjmuje postać:

$$
\mathrm{M}=\{\mathrm{J}, \mathrm{P}, \mathrm{S}, \mathrm{K}, \mathrm{Z}, \mathrm{C}, \mathrm{M}, \mathrm{I}, \mathrm{T}, \mathrm{D}\}
$$

gdzie:

$\mathrm{J}$ - zbiór języków symbolicznych użytych do opisu modelu,

$\mathrm{P}$ - zbiór postaci modelu (np. modele bilansowe, modele ekonometryczne),

$\mathrm{S}$ - zbiór rekomendacji decyzyjnych (np. model jednostrukturalny lub wielostrukturalny),

$\mathrm{K}$ - zbiór sposobów zapisu funkcji kryterialnej (jedokryterialne lub wielokryterialne),

$\mathrm{Z}$ - zbiór sposobów wyrażania zmiennych i występujących między nimi zależności (np. modele liniowe, modele nieliniowe),

$\mathrm{M}$ - zbiór metod stosowanych do rozwiązania problemu przedstawionego w modelu,

I - zbiór określający charakter informacji o parametrach zawartych w modelu,

$\mathrm{T}$ - zbiór środków technicznych niezbędnych do rozwiązania problemu zadanego w modelu,

D - zbiór lub grupa dziedzin, do których jest adresowany model (np. przemysł, usługi).

Z budową modelu wiąże się szereg czynności, prowadzących do jego określenia, wyboru jego składników, sytuacji badawczej, itp. Wszystkie te czynności określa się jako modelowanie.

Modelowaniem nazywamy doświadczalną metodę badania różnych układów, zjawisk i procesów lub rozwiązywanie zadań matematycznych na podstawie konstruowanych modeli.

Podstawą modelowania i analizy zjawisk są badania statystyczne. Jednym z podstawowych etapów badania statystycznego jest sformułowanie modelu statystycznego.

Modelem statystycznym nazywamy model semantyczny wyrażony układem $\mathrm{MS}=\langle\mathrm{S}, \mathrm{U}, \mathrm{Z}, \mathrm{F}\rangle$, w którym odpowiednie zbiory wyrażają:

$\mathrm{S}$ - zbiór sytuacji badania statystycznego,

$\mathrm{U}$ - zbiór wyspecyfikowanych zmiennych losowych,

$\mathrm{Z}$ - zbiór założeń przyjmowanych dla zmiennych losowych,

$\mathrm{F}$ - zbiór dopuszczalnych charakterystyk liczbowych z próby losowej.

Z podanej definicji wynika, że model statystyczny to układ założeń przyjmowanych wobec rozważanego badania statystycznego dla rozpatrywanego zbioru zmiennych losowych. Model statystyczny można także rozumieć jako układ pojęć i reguł statystyki matematycznej, odzwierciedlający badane empirycznie zjawisko, pozwalający na podstawie uzyskanych charakterystyk liczbowych z próby o badanych zmiennych losowych na jego interpretację poznawczą metodami statystycznymi. 


\subsection{Metody analizy dynamiki zjawisk}

Analiza dynamiki zajmuje się badaniem rozwoju zbiorowości w czasie. Podstawą analizy dynamiki zjawisk masowych są szeregi czasowe. Szeregiem czasowym nazywamy ciąg wartości badanego zjawiska obserwowanego w kolejnych jednostkach czasu. Miarami zmian poziomu zjawiska w czasie są indeksy statystyczne. Indeksy są wykorzystywane do opisu zmian charakteryzujących ekonomiczną działalność człowieka, np. produkcja, sprzedaż, koszty itp. Znajdują także zastosowanie w planowaniu i prognozowaniu ekonomicznym, są ważnym narzędziem wykorzystywanym $w$ analizach ekonomicznych zarówno w skali makroekonomicznej, jak i mikroekonomicznej. Przykładem indeksu wykorzystywanego do pomiaru rozwoju technologicznego danego kraju na tle innych krajów jest indeks zaawansowania technologicznego - TAI - Technnology Achievement Index (Desai i in. 2002). Innym przykładem wykorzystania indeksów w gospodarce jest Narodowy Indeks Potencjału Innowacyjnego - NICI - National Innovative Capacity Index (por. Porter, Stern 1999). W pracy wykorzystano metody analizy dynamiki do określenia przeciętnego poziomu wartości dodanej brutto, pracujących oraz podmiotów gospodarczych zarejestrowanych w sektorze usług w badanym przedziale czasowym. W celu ustalenia natężenia zmian poziomu wymienionych wskaźników w różnych okresach w stosunku do poziomu wskaźników z okresu przyjętego za podstawowy posłużono się indeksami dynamiki. Natomiast do wyodrębnienia tendencji rozwojowej (trendu) w kształtowaniu się wartości dodanej brutto wykorzystano funkcję trendu. Metody te są powszechnie znane i stosowane, dlatego przypominamy tylko niektóre dla wygody czytelnika.

Indeks $(i)$ to stosunek wielkości badanego zjawiska w okresie sprawozdawczym (badanym) $y_{n}$ do wielkości tego zjawiska w okresie przyjętym za podstawę $y_{0}$ (Domański red. 2001). Indeksy są wielkościami niemianowanymi, mogą być wyrażone w ułamku lub $\mathrm{w}$ procentach. Jeżeli $i>1$, oznacza to wzrost poziomu badanego zjawiska w okresie badanym $\mathrm{w}$ stosunku do okresu przyjętego za podstawę. Jeżeli $i<1$, świadczy to o spadku poziomu badanego zjawiska $\mathrm{w}$ stosunku do okresu podstawowego, w przypadku gdy $i=1$, to poziom zjawiska w okresie badanym i podstawowym pozostają takie same. W zależności od przyjętej podstawy porównań wyróżniamy indeksy:

- jednopodstawowe (o stałej podstawie),

$$
i_{n / 0}=\frac{y_{n}}{y_{0}}
$$


- łańcuchowe (o zmiennej podstawie)

$$
i_{n / n-1}=\frac{y_{n}}{y_{n-1}}
$$

Indeks o podstawie stałej mierzy zmiany, zachodzące w danym szeregu czasowym w stosunku do ustalonego okresu podstawowego. Indeks łańcuchowy mierzy krótkookresowe zmiany, które zachodzą w szeregu czasowym między dowolnie wybranym okresem a okresem bezpośrednio go poprzedzającym.

W szeregach czasowych możliwe jest badanie przeciętnego tempa zmian (wzrostu, spadku) zjawiska $\mathrm{z}$ okresu na okres. W tym celu wykorzystuje się średnią geometryczną.

$$
G=\sqrt[n-1]{i_{1 / 0} \times i_{2 / 0} \times \ldots \times i_{n / n-1}}=\sqrt[n-1]{\frac{y_{1}}{y_{0}} \times \frac{y_{2}}{y_{1}} \times \frac{y_{3}}{y_{2}} \times \ldots \times \frac{y_{n}}{y_{n-1}}}=\sqrt[n-1]{\frac{y_{n}}{y_{0}}}
$$

Średnia geometryczna spełnia warunek:

$$
i_{\min } \leq G \leq i_{\max }
$$

gdzie: $i_{\min }, i_{\max }$ oznaczają odpowiednio najmniejszy i największy indeks łańcuchowy występujący w badanym przedziale czasowym.

Ze względu na rodzaj badanych zjawisk wyróżniamy indeksy zespołowe dla wielkości absolutnych oraz indeksy zespołowe dla wielkości stosunkowych. Indeksy agregatowe stosowane są w przypadku analizy całego zespołu zjawisk niesumowalnych.

Drugą ważną grupą indeksów agregatowych są tzw. indeksy dla wielkości stosunkowych. Wielkości stosunkowe są wskaźnikami natężenia wyrażonymi jako iloraz dwóch zjawisk logicznie ze sobą powiązanych. Niektóre indeksy, które nie są stosowane w pracy, zostały pominięte.

Przedstawione metody analizy indeksowej pozwalają określić zmiany zjawiska w czasie. Obserwując zmienność zjawiska w czasie można wyodrębnić czynniki oddziałujące na jego poziom, są to: tendencja rozwojowa, wahania sezonowe i wahania przypadkowe. Tendencją rozwojową (trendem) nazywamy powolne, regularne i systematyczne zmiany określonego zjawiska, które są obserwowane $\mathrm{w}$ dostatecznie długim przedziale czasu i są rezultatem działania przyczyn głównych. Wyodrębnienia tendencji rozwojowej z szeregów czasowych najczęściej dokonuje się metodą mechaniczną, polegającą na wygładzaniu szeregu czasowego za pomocą tzw. średnich ruchomych, oraz metodą analityczną, 
która polega na znalezieniu funkcji obrazującej kształtowanie się zjawiska względem zmiennej czasowej. Istotnym zagadnieniem w metodzie analitycznej jest wybór odpowiedniej klasy funkcji trendu oraz prawidłowe oszacowanie jej parametrów. Do opisu zjawisk ekonomicznych najczęściej wykorzystywane są następujące funkcje tendencji rozwojowej (trendu):

- liniowa:

$$
\hat{Y}(t)=H(t)=\alpha+\beta t \quad \hat{y}(t)=f(t)=a+b t
$$

- paraboliczna:

$$
\hat{y}(t)=H(t)=\alpha+\beta_{1} t+\beta_{2} t^{2} \quad \hat{y}(t)=f(t)=a+b_{1} t+b_{2} t^{2}
$$

- wykładnicza:

$$
\hat{y}(t)=H(t)=\alpha \beta^{t} \quad \hat{y}(t)=f(t)=a+b^{t}
$$

- hiperboliczna:

$$
\hat{y}(t)=H(t)=\alpha+\beta t^{-1} \quad \hat{y}(t)=f(t)=a+b t^{-1}
$$

gdzie: $\hat{Y}(t)$ i $\hat{y}(t)$ oznaczają wartości teoretyczne w okresie $t$.

Parametry modelu trendu szacujemy metodą najmniejszych kwadratów, następnie wyznaczamy miary dopasowania modelu do danych empirycznych.

Wariancję resztową wyznaczamy według wzoru:

$$
S_{e}^{2}=\frac{1}{n-2} \sum_{t=1}^{n}\left(y_{t}-\hat{y}_{t}\right)^{2}
$$

Odchylenie standardowe składnika resztowego:

$$
S_{e}=\sqrt{S_{e}^{2}}
$$

informuje, o ile średnio odchylają się poszczególne wartości zmiennej $Y_{t}$ od wartości teoretycznych obliczonych z oszacowanej funkcji trendu.

Współczynnik zmienności resztowej:

$$
V_{e}=\frac{S_{e}}{\bar{y}}
$$


Współczynnik ten określa, jaki procent średniego poziomu zaobserwowanej zmienności zmiennej objaśnianej $Y_{t}$ stanowią, średnio rzecz biorąc, odchylenia przypadkowe w danym równaniu trendu.

Współczynnik zbieżności:

$$
\varphi^{2}=\frac{\sum_{t=1}^{n}\left(y_{t}-\hat{y}_{t}\right)^{2}}{\sum_{t=1}^{n}\left(y_{t}-\bar{y}_{t}\right)^{2}}
$$

Współczynnik zbieżności $\varphi^{2}$ mierzy tę część całkowitej zaobserwowanej zmienności zmiennej $Y_{t}$, która wynika z działania czynników losowych.

Współczynnik korelacji wielorakiej:

$$
R^{2}=1-\varphi^{2}
$$

Zarówno współczynnik $\varphi^{2}$, jak i $R^{2}$ należą do przedziału $\langle 0 ; 1\rangle$, przy czym $\varphi^{2}=0$, gdy $R^{2}=1$ i $\varphi^{2}=1$, gdy $R^{2}=0$. Możemy więc powiedzieć, że linia trendu tym lepiej pasuje do wyników obserwacji, im bardziej $\varphi^{2}$ zbliża się do 0 ( $R^{2}$ zbliża się do 1 ), a tym gorzej, gdy $\varphi^{2}$ zbliża się do 1 ( $R^{2}$ zbliża się do 0 ). Przypadek $\varphi^{2}=0$, czyli $R^{2}=1$ odpowiada sytuacji, w której zaobserwowane punkty leżą dokładnie na linii trendu, a przypadek, gdy $\varphi^{2}=1\left(R^{2}=0\right)$ odpowiada sytuacji maksymalnego możliwego odchylenia zaobserwowanych punktów empirycznych od najlepiej dopasowanej linii trendu.

\subsection{Wybrane miary zjawisk ekonomicznych}

Rozwój sektora usług jest wynikiem ciągłych zmian, jakie zachodzą w strukturze nie tylko sektora usług, ale także przemysłu i rolnictwa. Określenie poziomu rozwoju usług jest złożone, ponieważ brak jest uniwersalnych mierników, które byłyby w pełni porównywalne.

Różnorodność usług świadczy o braku możliwości ich porównywalności oraz ogranicza ich standaryzację i kontrolę poziomu jakości. Niematerialny charakter sprawia, że pomiar poziomu rozwoju jest stosunkowo skomplikowany. Wciąż trwają poszukiwania jednej, idealnej metody, która pozwoliłaby określić stopień ich rozwoju. Spośród szerokiego zbioru wskaźników wykorzystywanych do oceny poziomu rozwoju usług będą wyróżnione najczęściej stosowane. 
Daszkowska (1998, s. 51-52) wymienia trzy grupy mierników, które są wykorzystywane do oceny sektora usług:

a) mierniki naturalne (np. liczba przewiezionych osób w usługach transportowych, liczba przewiezionych ton ładunku, liczba noclegów w usługach hotelarskich itp.);

b) mierniki wartościowe wyrażone za pomocą cen;

c) mierniki umowne (np. liczba szkół wyższych na 10 tys. ludności, liczba telefonów komórkowych na 10 tys. ludności).

Według Styś i Olearnik (1985, s. 242) podstawą oceny działalności gospodarczej są mierniki, wyrażające w wielkościach liczbowych zjawiska gospodarcze występujące w działalności przedsiębiorstwa. Autorzy wyodrębniają dwie grupy mierników, określając je jako mierniki wartościowe i ilościowe.

Mierniki wartościowe określają efekty (rozmiary) wykonanych zadań gospodarczych, poziom poniesionych nakładów pracy żywej i uprzedmiotowionej, a także efektywność gospodarowania. Przykładem miernika wartościowego jest miernik określany jako wartość sprzedanych usług. Uwzględniając różnorodność usług, przyjęto, że miarą oceny efektywności gospodarowania w działalności usługowej są mierniki wartościowe. Mierniki ilościowe stosowane są głównie do ustalania sieci usług, np. liczby zakładów, punktów przyjęć itp.

$\mathrm{Z}$ kolei mierniki efektów informują o wielkości zrealizowanych usług, ich strukturze, rodzajach i jakości.

Mierniki nakładów są podstawą informacji o mocach przerobowych w działalności usługowej, o warunkach technicznych oraz strukturze i kwalifikacjach osób zatrudnionych w sektorze usług. Mierniki te mogą być także źródłem wiedzy o wielkości i strukturze nakładów pracy żywej i uprzedmiotowionej ponoszonych przy świadczeniu określonych rodzajów usług.

Następną grupą mierników są mierniki efektywności łączące w sobie informacje wyrażające stosunek uzyskanych efektów do poniesionych nakładów finansowych. Do grupy tych mierników można zaliczyć mierniki wydajności pracy, produktywnych środków trwałych lub w ujęciu syntetycznym mierniki rentowności działalności usługowej.

Obok wymienionych mierników istnieje jeszcze grupa określana jako syntetyczne mierniki finansowe, które można podzielić na absolutne (np. akumulacja finansowa, zysk i czysty dochód) i relatywne. Miernik finansowe określane jako relatywne wyrażają stosunek dwóch wielkości, z których pierwsza jest miernikiem absolutnym, natomiast druga odpowiednio dobraną podstawą odniesienia, którą może być np. wartość środków trwałych, koszty własne czy wartość sprzedanych usług. Wskaźniki finansowe odgrywają ważną rolę przy ocenie efektywności gospodarowania, zwłaszcza gdy są porównywane z ustaloną, konkretną liczbą normatywną, będącą odpowiednim wzorcem dla określonej grupy przedsiębiorstw, branż lub rodzajów usług. $\mathrm{W}$ analizie ekonomicznej działalności 
przedsiębiorstw można tworzyć wiele różnych wskaźników, np. rentowności, efektywności/zyskowności i wykorzystywać je do oceny poszczególnych rodzajów usług lub też innych porównań.

W literaturze zwraca się uwagę na wpływ usług niematerialnych (kapitału ludzkiego) na dochód narodowy. W szerokim ujęciu kapitał ludzki jest rozumiany jako ogół pracujących w gospodarce wraz $\mathrm{z}$ ich kwalifikacjami i wiedzą. Odpowiednie wykorzystanie kapitału ludzkiego powinno przynosić gospodarce określone efekty zarówno materialne, jak i niematerialne. W węższym ujęciu stosowanym na potrzeby teorii usług kapitał ludzki rozumiany jest jako pracujący w sferze niematerialnej. Podejście, mające na celu wyodrębnienie kapitału ludzkiego, ma służyć podniesieniu rangi zatrudnionych w sferze niematerialnej, a w dalszej konsekwencji uznania produktywnego charakteru efektów ich pracy. W celu określenia wielkości wpływu kapitału ludzkiego (usług niematerialnych) oznaczonego symbolem $u_{t}$ we wzroście dochodu narodowego Nieduszyński (por. Olearnik, Styś 1989, s. 55) proponuje wykorzystanie następującej formuły:

$$
u_{t}=\frac{K_{l_{i}}}{D_{i}} \quad(i=1,2, \ldots, n)
$$

gdzie:

$K_{l}$ - kapitał ludzki w przeliczeniu na 1 mieszkańca,

$D$ - dochód narodowy w przeliczeniu na 1 mieszkańca.

Kapitał ludzki w przeliczeniu na 1 mieszkańca zdefiniowano w następujący sposób:

$$
K_{l_{i}}=a \cdot N_{i}+b \cdot O_{i}+c \cdot Z_{i}+K_{i} \quad(i=1,2, \ldots, n)
$$

gdzie:

$a$ - współczynnik określający stopień przyspieszenia wpływu czynnika nauki na wzrost dochodu narodowego,

$N$ - nakłady na badania przeliczone na 1 mieszkańca,

$b$ - współczynnik określający stopień wpływu czynnika kształcenia na wzrost dochodu narodowego,

$O$ - nakłady na kształcenie przeliczone na 1 mieszkańca,

$c$ - współczynnik wpływu zdrowia na wzrost dochodu narodowego,

$Z$ - nakłady na polepszenie zdrowia przeliczone na 1 mieszkańca,

$K$ - nakłady na kulturę i sztukę przeliczone na 1 mieszkańca.

Nieduszyński, rozważając efekty działania niematerialnych czynników, do kapitału ludzkiego zaliczał: oświatę, naukę, postęp techniczny, kulturę i sztukę. 
Przedstawiony miernik jest przykładem sposobu określania efektywności usług niematerialnych.

W określaniu poziomu rozwoju usług w literaturze spotykamy także inne podejście wskaźnikowe charakteryzujące się trzema kryteriami, są to (Ilnicki 2009, s. 119-124):

- liczba pracujących w usługach,

- liczba instytucji usługowych ogółem lub poszczególnych ich rodzajów,

- możliwości lub warunki uczestnictwa w korzystaniu z usług.

W pierwszym z wymienionych kryteriów wymienia się trzy wskaźniki: wskaźnik struktury, wskaźnik natężenia rozwoju oraz tzw. wskaźnik podaży usług. Wskaźnik struktury określa całokształt prowadzonej działalności, gospodarki danego obszaru. Wskaźnik natężenia określa „atrakcyjność”, wynikającą ze struktury sektorowej prowadzonej działalności. Trzecia miara określana jest mianem podaży usług (PU). Jest ona relacją liczby pracujących w usługach do sumy pracujących w pozostałych dwóch sektorach, czyli:

$$
P U=\frac{P_{u}}{P_{p}+P_{r}}
$$

gdzie:

$P_{u}$ - liczba pracujących w usługach,

$P_{p}$ - liczba pracujących w przemyśle,

$P_{r}$ - liczba pracujących w rolnictwie.

Im wyższa jest wartość tego wskaźnika, tym wyższy jest poziom rozwoju usług. Jeżeli wartość wskaźnika podaży usług przekracza jeden, to świadczy to o dominacji sektora usług nad pozostałymi sektorami. Wskaźnik ten przedstawia relacje pomiędzy sektorem usług a tradycyjnie rozumianą produkcją, którą tworzy rolnictwo i przemysł.

Drugim kryterium, służącym do oceny rozwoju poziomu usług, jest liczba instytucji usługowych. Wskaźnik nasycenia usługami $N_{n u}$ określony jest wzorem:

$$
N_{n u}=\frac{L_{p u}}{P} \times C
$$

gdzie:

$L_{p u}$ - liczba placówek usługowych ogółem, lub danego rodzaju,

$P$ - wielkość popytu na usługi,

$C$-stała $(1,100,1000,10000, \ldots)$. 
Wskaźnik ten wykorzystywany jest głównie do określania stopnia rozwoju usług w zakresie infrastruktury społecznej.

Kolejnym określającym możliwości lub warunki uczestnictwa w korzystaniu z usług jest wskaźnik funkcjonowania usług $F_{u}$, który wyraża się wzorem:

$$
F_{u}=\frac{K_{u}}{W} \times C
$$

gdzie:

$K_{u}$ - liczba osób korzystających z usług,

$W$ - wielkość placówki, instytucji usługowej,

$C$ - stała $(1,100,1000,10000, \ldots)$.

Wskaźnik ten znajduje zastosowanie przede wszystkim przy ocenie rozwoju usług z zakresu tzw. infrastruktury społecznej.

Na uwagę zasługuje wskaźnik nasycenia firmami usługowymi w województwie $W_{N}$. Wskaźnik ten określa, ile osób przypada na jeden podmiot o charakterze usługowym, ma charakter destymulanty, dlatego pożądane są jego niskie wartości. Wyraża się następującym wzorem (Rozkrut 2008, s. 214):

$$
W_{N}=\frac{L_{L}}{L_{F U}}
$$

gdzie:

$L_{L}-$ ogólna liczba ludności województwa,

$L_{F U}$ - liczba podmiotów usługowych w analizowanym województwie.

W analizie sektora usług niejednokrotnie pojawia się potrzeba określenia wielkości potencjału usługotwórczego (zdolności usługowych). Potencjał usługotwórczy określa, ile usług można wytworzyć w organizacji usługowej w określonym czasie lub też jaka może być ogólna wartość wyświadczonych usług (Rogoziński 2000, s. 250-254). Zdolność usługowa może być rozpatrywana z punktu widzenia technicznego i techniczno-ekonomicznego, można ją wyznaczyć za pomocą odpowiednich metod, które można podzielić na metody opisowe i syntetyczne. Metody opisowe charakteryzują możliwości wytwórcze, wykorzystując dane dotyczące:

- obiektów (np. liczba placówek usługowych, punktów przyjęć),

- ludzi (np. wielkość zatrudnienia ogółem),

- urządzeń (liczba posiadanych urządzeń będących podstawą procesu obsługi),

- stanowisk pracy (liczba punktów obsługi klienta).

Daszkowska (1982, s. 87-89) do metod syntetycznych wyznaczania wielkości potencjału usługotwórczego zalicza: 
- metodę wskaźnika syntetycznego,

- metodę analityczną.

Metoda wskaźnika syntetycznego opiera się na założeniu, że podstawowym czynnikiem limitującym możliwości usługotwócze jest konkretne urządzenie czy maszyna. Zdolność usługową $Z_{u}$ określa się wzorem:

$$
Z_{u}=V \cdot T_{p}
$$

gdzie:

$V$ - zdolność produkcyjna urządzenia mierzona ilością usług na jednostkę czasu (godzinę, dobę, zmianę),

$T_{p}$ - liczba jednostek czasu.

Metoda analityczna opiera się na rachunku ekonomicznym, polega na odniesieniu roboczogodzin do czasu pracy, który jest konieczny do wykonania danej usługi. W proponowanej metodzie obliczanie możliwości usługotwórczych przebiega etapowo. Najpierw określa się sumę roboczogodzin poszczególnych stanowisk i stopień wykorzystania tych roboczogodzin, następnie oblicza się przepustowość $P$ stanowisk pracy według wzoru:

$$
P=\frac{T_{d}}{N_{h}}
$$

gdzie:

$T_{d}-$ dysponowany fundusz czasu pracy dla stanowiska tworzącego tzw. wąski przekrój,

$N_{h}$ - pracochłonność skorygowana o procent wykonania norm pracy przypadającej na stanowisko tworzące wąski przekrój.

W dalszej kolejności przechodzi się do wyznaczenia możliwości usługotwórczych $Z_{u}$ według następującej formuły:

$$
Z_{u}=P \cdot f \cdot b
$$

gdzie:

$P$ - przepustowość,

$f$ - optymalny współczynnik ciągłości obciążenia stanowisk w okresie obliczeniowym,

$b$ - optymalny współczynnik bezbłędnego (poprawnego) wykonania usługi.

Przytoczone miary są tylko jednymi z wielu, które są wykorzystywane do badania poziomu rozwoju usług. Pomiaru wielkości sektora usług można także 
dokonać, kierując się kryterium nakładów czynników produkcji i efektów produkcyjnych. Do pierwszego z kryterium możemy zaliczyć:

- liczbę pracujących w sektorze usług, która jest naturalnym miernikiem ilości zaangażowanej $\mathrm{w}$ usługach pracy ludzkiej. Na jej podstawie możemy obliczyć stopień absorpcji siły roboczej w poszczególnych rodzajach usług oraz określić poziom rozwoju sektora usług;

- liczbę pracowników z wykształceniem wyższym w sektorze usług;

- zaangażowany kapitał rzeczowy;

- podejmowane inwestycje.

Kierując się kryterium efektów produkcyjnych, wyróżniamy:

- wartość PKB wytwarzaną w sektorze usług,

- wartość dodana,

- wartość przychodów z produkcji sprzedanej w sektorze usług.

Ważnym i często stosowanym miernikiem $\mathrm{w}$ określaniu miejsca i znaczenia sektora usług w gospodarce jest wartość dodana brutto.

Przytoczone miary świadczą o złożoności problemu, jakim jest pomiar sektora usług. Do oceny rozwoju sektora usług najczęściej wykorzystuje się analizy struktur zatrudnienia i wartości dodanej brutto. Dzięki analizom porównawczym struktur zatrudnienia i tworzenia wartości dodanej brutto różnych krajów możemy otrzymać informacje o stopniu rozwoju sektora usług, dystansie, jaki dzieli poszczególne kraje, oraz o stopniu rozwoju poszczególnych rodzajów usług. Świadomość wpływu na rozwój sektora usług wielu różnych zmiennych skłoniła do zastosowania do dalszych badań analizy czynnikowej. Analiza czynnikowa jest jedną $z$ metod wykorzystywanych $w$ analizach rynku $\mathrm{i}$ jest stosowana wówczas, gdy mamy do czynienia z dużą liczbą zmiennych.

\subsection{Analiza czynnikowa}

Analiza czynnikowa jest metodą wykorzystywaną do analizy struktury zależności zmiennych, które mają podobny charakter lub nie mamy żadnych informacji a priori, mówiących o zależnościach między nimi. Analiza czynnikowa polega na odnajdywaniu nowego zbioru zmiennych, mniej licznego niż zbiór zmiennych oryginalnych, które zachowują stosunkowo dużą część informacji tkwiących w zmiennych pierwotnych. Celem wykorzystania metod analizy wielowymiarowej $\mathrm{w}$ pracy było wyodrębnienie czynników mogących pomóc w ocenie rozwoju sektora usług.

Analiza czynnikowa jest metodą statystyczną, która na podstawie zachodzących między zmiennymi korelacji wyodrębnia czynniki, które nie są bezpośrednio obserwowalne (Gatnar, Walesiak 2004). Czynniki te zachowują znaczną część informacji zawartych w zmiennych pierwotnych i mają inną interpretację 
merytoryczna. Analiza czynnikowa wymaga dużych prób oraz normalizacji rozkładów poszczególnych zmiennych (por. Andreasen 1988, Morrison 1990, Walesiak 1993)

W modelu analizy czynnikowej (por. Morrison 1990, s. 449; Ostasiewicz 1998, s. 214; Gatnar, Walesiak 2004, s. 186; Kopczewska, Kopczewski, Wójcik 2009 , s. 402) zakłada się, że każda z obserwowanych zmiennych $X_{i}, i=1, \ldots, p$ jest funkcją liniową zmiennych nieobserwowanych, tzw. czynników wspólnych $F_{1}, \ldots, F_{k}(k<p)$ oraz pojedynczej zmiennej $u_{i}$. Bez straty ogólności przyjmuje się, że zmienne $X_{i}, i=1,2, \ldots, p$ są zestandaryzowane.

Model ten można zapisać w postaci:

$$
\begin{aligned}
& X_{1}=a_{11} F_{1}+a_{12} F_{2}+\ldots+a_{1 k} F_{k}+u_{1} \\
& X_{2}=a_{21} F_{1}+a_{22} F_{2}+\ldots+a_{2 k} F_{k}+u_{2} \\
& X_{p}=a_{p 1} F_{1}+a_{p 2} F_{2}+\ldots+a_{p k} F_{k}+u_{p}
\end{aligned}
$$

gdzie:

$a_{i j}$ - oznacza współczynnik kombinacji liniowej określający związek pomiędzy zmienną rzeczywistą $X_{i}$ i czynnikiem $F_{j}$ nazywanym ładunkiem czynnikowym;

$F_{j}$ - czynnik wspólny, czyli nieobserwowalna zmienna, kształtująca wartości zmiennych rzeczywistych dla $j=1, \ldots, k$;

$u_{i}$ - czynnik losowy określający zakres oddziaływania zjawisk nieprzewidywanych na odwzorowanie czynników w poszczególne zmienne rzeczywiste dla $i=1,2, \ldots, p$.

Wprowadzając następujące oznaczenia:

$$
X=\left[X_{1}, \ldots, X_{p}\right]^{T}, F=\left[F_{1}, \ldots, F_{k}\right]^{T}, \quad A=\left[a_{i j}\right], \quad u=\left[u_{1}, \ldots, u_{p}\right]^{T},
$$

$i=1, \ldots, p, j=1, \ldots, k$, otrzymujemy model w postaci równania:

$$
\mathbf{X}=\mathbf{A F}+\mathbf{u}
$$

Zadaniem analizy czynnikowej jest, aby mając daną macierz obserwacji $\mathbf{X}$, wyznaczyć macierz ładunków czynnikowych A, przyjmując następujące założenia:

- czynniki wspólne $F$, nie są skorelowane między sobą,

- czynniki specyficzne $u_{i}$, nie są skorelowane między soba,

- czynniki wspólne nie są skorelowane z czynnikami specyficznymi,

- czynniki wspólne są zestandaryzowane, tzn. $E\left(F_{i}\right)=0 \mathrm{i} V\left(F_{i}\right)=1$, 
- $E\left(u_{i}\right)=0, V\left(u_{i}\right)=\sigma_{u_{1}}^{2}$-jest to tzw. swoistość albo inaczej wariancja specyficzna.

Na podstawie przyjętych założeń wariancję dowolnej zmiennej $X_{i}$ można zapisać:

$$
\begin{gathered}
V\left(X_{i}\right)=E\left(X_{i}\right)^{2}=E\left(a_{i 1} F_{1}+a_{i 2} F_{2}+\ldots+a_{i k} F_{k}+u_{i}\right)^{2}= \\
=E\left(a_{i 1}^{2} F_{1}^{2}+\ldots+a_{i k}^{2} F_{k}^{2}+2 a_{i 1} a_{i 2} F_{1} F_{2}+\ldots+2 a_{i 1} a_{i k} F_{1} F_{k}+\ldots+\right. \\
\left.+2 a_{i k-1} a_{i 2} F_{k-1} F_{k}+2 a_{i 1} F_{1} u_{i}+\ldots+2 a_{i k} F_{k} u_{i}+u_{i}^{2}\right)=a_{i 1}^{2}+a_{i 2}^{2}+\ldots+a_{i k}^{2}+\sigma_{u_{i}}^{2}
\end{gathered}
$$

A zatem zachodzi równość:

$$
V\left(X_{i}\right)=1=h_{i}^{2}+\sigma_{u_{i}}^{2} \text { gdzie } h_{i}^{2}=a_{i 1}^{2}+a_{i 2}^{2}+\ldots+a_{i k}^{2}
$$

Wariancja zmiennej $X_{i}$ równa 1 jest sumą dwóch składników, z których jednym tzw. zasobem zmienności wspólnej $h_{i}^{2}$, jest ta część całkowitej wariancji zmiennej $X_{i}$, która jest wyjaśniona przez czynniki wspólne $F_{1}, \ldots, F_{k}$. Drugim składnikiem jest wariancja specyficzna, czyli pozostała część wariancji zmiennej $X_{i}$, uwzględniająca tylko wpływ zmiennej specyficznej $u_{i}$.

Można także wykazać, że kowariancja między zmiennymi $X_{i}$ oraz $X_{j}$ nie zależy od wariancji specyficznej, ponieważ zachodzi równość:

$$
\operatorname{Cov}\left(X_{i}, X_{j}\right)=\sum_{m=1}^{k} a_{i m} a_{j m} \text { dla } i \neq j ; i=1,2, \ldots, p ; j=1,2, \ldots, p
$$

Poza tym można zauważyć, że:

$$
\operatorname{Cov}\left(X_{i}, F_{j}\right)=a_{i j} \text { dla } i=1,2, \ldots, p ; j=1,2, \ldots, k
$$

oraz

$$
\operatorname{Cov}\left(X_{i}, u_{i}\right)=V\left(u_{i}\right)
$$

Macierz kowariancji wektora X przyjmuje postać:

$$
\mathbf{C}=\mathbf{A} \mathbf{A}^{T}+\mathbf{V}
$$

gdzie: A jest macierzą ładunków czynnikowych, a $\mathbf{V}$ diagonalną macierzą, w której elementami głównej przekątnej są kolejne wariancje specyficzne. 
$\mathrm{W}$ analizie czynnikowej najczęściej korzysta się $\mathrm{z}$ macierzy korelacji $\mathbf{R}=\left[r_{i j}\right] i, j=1,2, \ldots, p$ wyznaczonej zgodnie ze wzorem

$$
\mathbf{R}=\frac{1}{n} \mathbf{X}^{T} \mathbf{X}
$$

Można także dokonać przekształcenia macierzy obserwacji $\mathbf{X}$ w taki sposób, aby zachodziła równość:

$$
\mathbf{R}=\mathbf{X}^{T} \mathbf{X}
$$

Element głównej przekątnej macierzy $\mathbf{R}$ można interpretować w dwojaki sposób jako: całkowitą wariancję każdej zmiennej oraz jako współczynnik korelacji zmiennej z nią sama, czyli $V\left(X_{i}\right)=r_{X_{i} X_{i}}=1$. Elementy te uwzględniają wpływ czynników zarówno wspólnych, jak i specyficznych. Pozostałe elementy tej macierzy są współczynnikami korelacji między $X_{i}$ a $X_{j} i \neq j ; i, j=1,2, \ldots, p$, czyli $r_{X_{i} X_{j}}=r_{i j}$.

Ponieważ

$$
r_{i j}=\frac{\operatorname{Cov}\left(X_{i}, X_{j}\right)}{\sqrt{V\left(X_{i}\right) V\left(X_{j}\right)}}
$$

Uwzględniając $V\left(X_{i}\right)=V\left(X_{j}\right)=V\left(F_{i}\right)=1 \quad V\left(u_{i}\right)=\sigma_{u_{i}}^{2}$.

Otrzymujemy:

$$
\begin{gathered}
r_{i j}=\sum_{m=1}^{k} a_{i m} a_{j m} \\
r_{X_{i} F_{j}}=a_{i j} i=1,2, \ldots, p ; j=1, \ldots, k \\
r_{X_{i} u_{j}}=\sqrt{V\left(u_{i}\right)}=\sigma_{u_{i}} \quad i=1,2, \ldots, p
\end{gathered}
$$

Aby wyeliminować czynniki specyficzne, tworzy się tzw. zredukowaną macierz korelacji $\mathbf{R}^{1}$, umieszczając na głównej przekątnej macierzy $\mathbf{R}$ zasoby zmienności wspólnej $h_{j}^{2}$ zamiast 1 . Należy zauważyć, że wartości $h_{j}^{2}$ niezbędne 
do określenie zredukowanej macierzy korelacji $\mathbf{R}^{1}$ są szacowane w różny sposób. Najczęściej wykorzystuje się do tego celu następujące wzory:

$$
h_{i}^{2}=\frac{r_{i j} r_{i m}}{r_{j m}} \quad i=1,2, \ldots, p
$$

gdzie: $r_{i j} r_{i m}$ oznaczają najwyższe wartości współczynników korelacji zmiennej $X_{i}$, z pozostałymi zmiennymi (czyli $X_{j}$ oraz $X_{m}$ są najsilniej skorelowane z $X_{j}$ ) lub

$$
h_{i}^{2}=\max \left|r_{i j}\right| i \neq j \quad i, j=1,2, \ldots, p
$$

czy

$$
h_{i}^{2}=\frac{1}{p-1} \sum_{m=1}^{p} r_{i m} \quad m \neq i
$$

Wartości liczbowe $h_{i}^{2}$ otrzymane za pomocą powyższych wzorów różnią się między sobą, ale w rezultacie dają zbliżone wyniki właściwej analizy czynnikowej.

Macierz $\mathbf{R}^{1}$ ma zatem postać:

$$
R^{1}=\left[r_{i j}^{1}\right]
$$

gdzie: $r_{i j}^{1}=h_{i}^{2}$ dla $i=j$ oraz $r_{i j}^{1}=r_{i j}$ dla $i \neq j ; i, j=1, \ldots, p$

Model sprowadza się wówczas do postaci:

$$
\mathbf{X}=\mathbf{A F}
$$

Opierając się na wcześniejszych wzorach, można pokazać, że w takim modelu zachodzą następujące związki:

$$
\begin{gathered}
V\left(X_{i}\right)=h_{i}^{2}=r_{X_{i} X_{i}} \quad i=1,2, \ldots, p \\
r_{i j}^{1}=\sum_{m=1}^{k} a_{i m} a_{j m} \quad i \neq j ; i, j=1,2, \ldots, p
\end{gathered}
$$

Można zauważyć, że wyeliminowanie z modelu czynników specyficznych wpłynęło tylko na zmianę wariancji wektorów $X_{i}$, współczynniki korelacji mię- 
dzy zmiennymi $X_{i}$ oraz $X_{j}$ nie ulegają zmianie. Zależności przedstawione powyższymi wzorami w zapisie macierzowym przyjmują postać równania:

$$
\mathbf{R}^{1}=\mathbf{A} \mathbf{A}^{T},
$$

które muszą spełniać ładunki czynnikowe, wyznaczone za pomocą odpowiednich metod.

Z przedstawionych rozważań wynika, że podstawowe zadanie analizy czynnikowej sprowadza się do rozwiązania powyższego równania ze względu na macierz A. Znalezienie tego rozwiązania kończy właściwą analizę czynnikową. Istnieje kilka sposobów znajdywania czynników. Jedną z metod ich wyodrębniania jest metoda składowych głównych, która wyznaczy wartości i wektory własne nie modyfikowanej macierzy korelacji. Druga często stosowana to metoda czynników głównych, za pomocą której wyznaczymy wartości i wektory własne macierzy korelacji z zmodyfikowanymi wartościami na przekątnej. $\mathrm{W}$ obu metodach znalezione wektory własne nazywa się czynnikami, a wartości własne związane z nimi są proporcjonalne do procentu wyjaśnionej wariancji przez dany czynnik. Celem obu metod jest uzyskanie najistotniejszych czynników lub składowych spośród zmiennych pierwotnych opisujących analizowane zagadnienie (Malarska 2005).

Po wyznaczeniu ładunków czynnikowych można określić, jaki wpływ mają poszczególne czynniki na wariancję wszystkich zmiennych $X$. Wiadomo, że $V\left(X_{i}\right)=1$, więc całkowita wariancja zmiennych $X_{1}, \ldots, X_{p}$ wynosi $p$, a więc

$$
\frac{1}{p} \sum_{i=1}^{p} a_{i j}^{2} 100 \%, \quad j=1,2, \ldots, k
$$

określa, jaki procent wariancji wszystkich zmiennych wyjaśnia czynnik $\mathbf{F}_{\mathbf{j}}$. Nakładając na macierz A ładunków czynnikowych dodatkowy warunek postaci:

$$
\mathbf{A}^{T} \mathbf{A}=\mathbf{I}
$$

gdzie: I oznacza macierz jednostkową, można obliczyć macierz F, której elementami są wartości poszczególnych czynników dla kolejnych obiektów. Macierz tę znajduje się według wzoru:

$$
\mathbf{F}=\mathbf{A}^{T} \mathbf{X}
$$

Zmienne występujące w badaniu są poddawane standaryzacji. Dążąc do znalezienia nowych zmiennych, dla każdego czynnika obliczana jest jego wartość 
własna, czyli wariancja zawarta w tym czynniku. Problemem jest wybór najważniejszych czynników. Wydaje się, że najlepszym podejściem jest przeprowadzenie wielu analiz czynnikowych dla różnej liczby zadanych czynników i znalezienie takiej liczby czynników, dla której struktura czynnikowa daje się najlepiej opisać czy nazwać. Jest to najlepszy sposób, lecz jednocześnie najbardziej pracochłonny, dlatego też istnieje możliwość użycia dwóch kryteriów, które pozwalają ograniczyć liczbę czynników z dołu i z góry. Brak jest jednoznacznej metody wyboru liczby czynników. Można z góry ograniczyć liczbę czynników, opierając się na tzw. kryterium Kaisera (2002), zostawiając tylko czynniki, które mają wartości własne większe niż 1. Jeżeli czynnik nie wyjaśnia zmienności przynajmniej tyle, ile wynosi jedna zmienna oryginalna, należy go odrzucić.

Minimalną liczbę czynników ocenia się na podstawie graficznej oceny wartości własnych kolejnych czynników. Ponieważ wartości własne maleją dla kolejnych czynników, wykres swym kształtem jest podobny do osypiska skalnego. Szukanie optymalnej liczby czynników polega na znajdywaniu tzw. punktów przegięć wykresu osypiska, a metoda nazywa się testem osypiska zaproponowanym przez Cattella (Cattell 1966).

W dalszej kolejności, w celu łatwiejszej interpretacji czynników, dokonujemy rotacji, czyli „obracania” układu współrzędnych, w którym znajdują się nasze dane. Rotacja polega na sprowadzeniu struktury ładunków czynnikowych do prostej struktury, w której punkty reprezentujące zmienne skupiają się wokół osi - czynników. Można dokonać dowolnej rotacji wybranych czynników, czyli takiej transformacji, która jest wzajemnie jednoznaczna, ale zachowuje liniową niezależność czynników, czyli to, że ich wzajemna korelacja jest równa dokładnie zero. Dzięki temu, że obroty zachowują prostopadłość (czyli niezależność od siebie) czynników, jest to szczególnie przydatna klasa transformacji. Jednak obracać można na wiele sposobów, szczególnie jeśli mamy do czynienia z wielowymiarową przestrzenią (obroty dzieją się w przestrzeni rozpinanej przez znalezione czynniki, czyli w przestrzeni o tylu wymiarach, ile jest czynników).

Najczęściej stosowaną metodą rotacji jest ortogonalna rotacja varimax (Kopczewska, Kopczewski, Wójcik 2009). Jest to algorytm szukający takiego obrotu, który maksymalizuje sumę wariancji ładunków czynnikowych wszystkich czynników. Preferowane są takie czynniki, dla których dana zmienna należy tylko do jednego czynnika, a unikane są sytuacje, w których jedna zmienna należy w równym stopniu do co najmniej dwóch czynników. Dzięki temu najłatwiej jest opisywać czynniki. W praktyce stosuje się jeszcze nie będące obrotami transformacje z rodziny oblimin (ang. oblique), oznaczającego tutaj skośność, czyli brak zachowania prostopadłości czynników do siebie. Skorelowane ze sobą (czyli nieprostopadłe) czynniki kreują dodatkowe problemy matematyczne i dlatego są rzadziej stosowane. Podstawową informacją używaną do nazwania 
czynników i oceny wyników analizy czynnikowej są wartości ładunków czynnikowych.

Weryfikacja istotności macierzy korelacji zawierającej współczynniki korelacji pomiędzy wszystkimi zmiennymi obserwowalnymi przeprowadzana jest za pomocą testu sferyczności Bartletta (por. Morrison 1990, Everitt 2002). Sprawdzamy hipotezę, że macierz korelacji jest macierzą jednostkową. Statystyka testu dla tej hipotezy przyjmuje postać:

$$
\chi^{2}=-\left(n-1-\frac{2 p+5}{6}\right) \log |R|
$$

gdzie:

$n$ - liczba próbek,

$p$ - liczba zmiennych obserwowanych,

$|R|$ - wyznacznik macierzy współczynników korelacji zmiennych obserwowanych.

Przy założeniu prawdziwości hipotezy zerowej statystyka (2.49) ma rozkład chi-kwadrat o liczbie stopni swobody $\frac{p(p-1)}{2}$.

Następnym elementem jest ocena adekwatności próby do założeń analizy czynnikowej. Przeprowadza się to za pomocą współczynnika Kaisera-MayeraOlkina (KMO) (Kaiser, 1974), który przyjmuje postać:

$$
K M O=\frac{\sum_{i \neq j} \sum_{j \neq i} r_{i j}^{2}}{\sum_{i \neq j} \sum_{j \neq i} r_{i j}^{2}+\sum_{i \neq j} \sum_{j \neq i} a_{i j}^{2}}
$$

gdzie:

$r_{i j}$ - element macierzy korelacji $\mathbf{R}$,

$a_{i j}$ - współczynnik korelacji cząstkowej pomiędzy zmiennymi.

Współczynnik ten przyjmuje wartości z przedziału [0,1]. Im wyższe wartości tego współczynnika, tym większe są podstawy do stosowania analizy czynnikowej (zaleca się $K M O>0,5$ ) w ocenie związków pomiędzy zmiennymi obserwowanymi. Gdy współczynniki korelacji pomiędzy zmiennymi są istotne, na co wskazują wyniki testu Barletta, wielkość współczynnika $K M O$ daje podstawy do konstrukcji modelu analizy czynnikowej, co wstępnie należy ocenić, w jakim stopniu każda ze zmiennych obserwowanych związana jest z pozostałymi zmiennymi. Wysoki stopień uzależnienia wskazuje na znaczną wielowymiarowość ukrytych czynników i zasadność redukcji. Stopień tej zależności opisuje 
zmienność wspólna, która jest sumą kwadratów ładunków stojących przy czynnikach w każdym równaniu modelu (2.24). Dla zmiennej rzeczywistej $x_{i}$ zmienność wspólna określająca jak zmienna $x_{i}$ zależy od pozostałych zmiennych, wynosi $\sum_{j=1}^{k} a_{i j}^{2}$. Suma kwadratów stojących przy pojedynczym czynniku dla wszystkich równań modelu wyznacza wariancję tego czynnika i jest wartością własną macierzy korelacji. Wartości zmienności wspólnej powstają jako sumy w kolejnych wierszach macierzy kwadratów ładunków, wartości własne zaś powstają jako sumy w kolejnych kolumnach tej macierzy.

Jeżeli w macierzy korelacji $\mathbf{R}$ elementy głównej przekątnej zastąpi się zasobami zmienności wspólnej $\left(h_{i}^{2}\right)$, to tak przekształcona macierz nosi nazwę zredukowanej macierzy korelacji $\widetilde{\mathbf{R}}$. Ograniczenie takie prowadzi do wyeliminowania czynnika losowego z równań modelu analizy czynnikowej w skoncentrowaniu analizy na zmienności wspólnej badanych zmiennych. Model analizy czynnikowej redukuje się wówczas do modelu głównych składowych. Wartości $h_{i}^{2}$ dla danej zmiennej wyznacza się na podstawie wartości średniej współczynników korelacji tej zmiennej z pozostałymi lub jako wartości maksymalne spośród współczynników korelacji tej zmiennej z pozostałymi.

\subsection{Skalowanie wielowymiarowe}

Skalowanie wielowymiarowe (Multidimensional Scaling, MDS) jest metodą eksploracyjną pozwalającą na przedstawienie wielowymiarowych wykresów rozrzutu na dwu- (lub trój- lub arbitralnie mało) wymiarowych wykresach (por. Quinn, Keough 2001). Metoda ta została wykorzystana w pracy do określenia podobieństw lub różnic $\mathrm{w}$ badaniu rozwoju sektora usług $\mathrm{w}$ ujęciu województw. Metoda jest oparta na założeniu, że respondent, wyrażając swój stosunek do rzeczywistości operuje wymiarami, traktując obiekty (produkty, ludzi, przedmioty itp.) jako punkty w przestrzeni $m$-wymiarowej. Celem skalowania wielowymiarowego jest przedstawienie „struktury” badanych obiektów poprzez określenie treści wymiarów na podstawie podobieństw i preferencji respondentów oraz zachodzących w przestrzeni $r$-wymiarowej $(r<m)$ relacji zachodzących między badanymi obiektami (Gatnar, Walesiak 2004). W pracy posłużono się skalowaniem wielowymiarowym dla określenia podobieństw i różnic w rozwoju sektora usług w badanych województwach. Przyjmujemy, że (Walesiak, Gatnar 2009, s. 354-356):

1. Obiekty tworzą zbiór $A$, a niepodobieństwa określone na iloczynie kartezjańskim $A \times A$ między obiektami $i$ oraz $k$ wynoszą $\delta_{i k}$, tworząc $\Delta\left[\delta_{i k}\right]_{n \times n}$, gdzie $n$ jest liczbą obiektów. 
2. $\Phi$ będzie odwzorowaniem zbioru $A$ w zbiór punktów $X$, gdzie $X$ jest podzbiorem przestrzeni, w której zostaną przedstawione obiekty, Tak więc $\Phi\left(A_{i}\right)=x_{i}$, przy czym $x_{i}$ jest punktem w przestrzeni $r$-wymiarowej.

3. $d_{i k}$ będzie odległością między $x_{i}$ a $x_{k}$.

Należy znaleźć takie odwzorowanie $\Phi$, dla którego $d_{i k} \approx \hat{d}_{i k}=f\left(\delta_{i k}\right)$, gdzie $\hat{d}_{i k}$ jest funkcją regresji między $d_{i k}$ a $\delta_{i k}$. W zależności od charakteru zmiennych opisujących badane obiekty, funkcja $\Phi$ musi spełniać odpowiednie warunki (Takane, Young i de Leeuw 1977; Young, de Leeuwi Takane 1976; za Walesiak, Gatnar 2009):

- dla zmiennych dyskretnych

$$
\delta_{i k} \sim \delta_{i^{\prime} k^{\prime}} \Rightarrow \hat{d}_{i k}=\hat{d}_{i^{\prime} k^{\prime}}
$$

gdzie: $\delta_{i k} \sim \delta_{i^{\prime} k^{\prime}}$ oznacza, że niepodobieństwa między obiektami $i$ a $k$ oraz obiektami $i^{\prime}$ a $k^{\prime}$ są oceniane jednakowo

- dla zmiennych ciaggłych

$$
\delta_{i k} \sim \delta_{i^{\prime} k^{\prime}} \Rightarrow l \leq \hat{d}_{i k}, \hat{d}_{i^{\prime} k^{\prime}} \leq u
$$

gdzie: $\langle l ; u\rangle$ - określony przedział,

- dla zmiennych mierzonych na skali porządkowej

$$
\delta_{i k} \prec \delta_{i^{\prime} k^{\prime}} \Rightarrow \hat{d}_{i k} \leq \hat{d}_{i^{\prime} k^{\prime}}
$$

- dla zmiennych mierzonych na skali przedziałowej lub ilorazowej $\hat{d}_{i k}$ jest liniowo zależne od $\delta_{i k}$, tak że

$$
\hat{d}_{i k}=a_{0}+a_{1} \delta_{i k}
$$

przy $a_{0}=0$ dla zmiennych mierzonych na skali ilorazowej.

Kruskal podał następująca definicję wartości dopasowania STRESS (Standardized Residual Sum of Squares) (1964):

$$
\text { STRESS }=\left[\frac{\sum_{i} \sum_{k}\left(d_{i k}-\hat{d}_{i k}\right)^{2}}{\sum_{i} \sum_{k} d_{i k}^{2}}\right]^{\frac{1}{2}}
$$


Tokone i inni (1977) przedstawiają miarę postaci:

$$
\text { STRESS }=\left[\frac{\sum_{i} \sum_{k}\left(d_{i k}-\hat{d}_{i k}\right)^{2}}{\sum_{i} \sum_{k} d_{i k}^{4}}\right]^{\frac{1}{2}}
$$

Przyjmuje się, że jeżeli STRESS przyjmuje wartości powyżej $20 \%$, to dopasowanie jest uznawane za bardzo słabe, jeżeli znajduje się w przedziale od 10 do $20 \%$ to słabe, od 5 do $10 \%$ średnie, od 2 do $5 \%$ dobre, od 0 do $2 \%$ bardzo dobre, powyżej $0 \%$ idealne. Jest to miara dopasowania, która zależy od wielu czynników (Borg i Groenen 2005, s. 54-55, za Walesiak, Gatnar 2009, s. 355), między innymi od liczby obiektów $n$ (im większa wartość $n$ tym większa wartość STRESS), liczby wymiarów $r$ (im większa wartość $r$, tym mniejsza wartość STRESS) oraz błędów występujących w danych (im więcej błędów, tym większa wartość STRESS).

Wykresy rozrzutu wyprodukowane przez skalowanie wielowymiarowe mają arbitralną rotację - oznacza to, że osie współrzędnych są arbitralnie wybrane. Ta cecha dla skalowania wykonanego na macierzy korelacji zmiennych jest konceptualnie tym samym, czym jest rotacja $\mathrm{w}$ analizie czynnikowej, $\mathrm{z}$ tą różnicą, że zwyczajowo w MDS nie szuka się rotacji, która spełnia jakieś kryteria (np. Varimax) (por. Quinn, Keough 2001).

Jeśli obiektami są zmienne, a jako odległości między zmiennymi zadamy macierz korelacji zmiennych ze sobą, to wyniki skalowania wielowymiarowego są metodą porównywalną z analizą czynnikową. Różnica polega na tym, że analiza czynnikowa dokonuje grupowania zmiennych, a skalowanie wielowymiarowe produkuje wykres rozrzutu, na podstawie, którego to człowiek na podstawie swojej intuicji sam znajduje skupiska i/lub zmienne odstające.

Nie zawsze uzyskana reprezentacja obiektów jest idealnie wierna, jeśli przestrzeń rozwiązań ma mniejszy wymiar niż liczba obiektów +1 , jeśli zada się macierz odległości między n obiektami, to można zawsze w idealny sposób odtworzyć lokalizację punktów odpowiadających obiektom w przestrzeni $n-1$ wymiarowej. Jeśli chcemy odtworzyć lokalizację punktów w przestrzeni o niższym wymiarze, to uzyskane wyniki mogą być tylko przybliżone.

Metoda skalowania wielowymiarowego na podstawie wyników oceny bliskości między obiektami lub zmiennymi poszukuje ich przestrzennej reprezentacji. Metoda ta jest pewnego rodzaju techniką redukcji danych, ponieważ jej celem jest znalezienie takiego zbioru punktów w przestrzeni o niewielkiej liczbie wymiarów, które będą dobrze reprezentować konfigurację badanych obiektów lub zmiennych w przestrzeni wielowymiarowej. 


\subsection{Miary Hellwiga i Perkala}

Pomimo wielu różnorodnych metod pomiaru rozwoju gospodarki, pomiar rozwoju sektora usług nadal stanowi poważny problem. Ze względu na złożoność tego problemu i próbę zwrócenia uwagi na wiele różnych czynników mających wpływ na rozwój sektora usług pomocnym narzędziem okazała się syntetyczna miara służąca do badania poziomu rozwoju zjawisk społecznogospodarczych zaproponowana przez Z. Hellwiga (1968). Jest to miara zaliczana do grupy metod wzorcowych, wykorzystywana do liniowego porządkowania elementów danej zbiorowości. Poddawane badaniu obiekty (np. województwa) porządkowane są zgodnie z wzorcem rozwoju, którym jest obiekt abstrakcyjny, pozwala to identyfikować poziom ich rozwoju. Punktem wyjścia jest macierz obserwacji o postaci:

$$
X=\left[\begin{array}{cccc}
x_{11} & x_{12} & \ldots & x_{1 m} \\
x_{21} & x_{22} & \ldots & x_{2 m} \\
\vdots & \vdots & \vdots & \vdots \\
x_{n 1} & x_{n 2} & \ldots & x_{n m}
\end{array}\right]
$$

Następnie wartość $X_{j}$ w badanej zbiorowości obiektów poddajemy standaryzacji zgodnie ze wzorem:

$$
z_{i j}=\frac{x_{i j}-\bar{x}_{j}}{s_{j}}
$$

gdzie:

$x_{i j}$ - wyjściowe wartości $j$-tej cechy w $i$-tym obiekcie,

$z_{i j}$ - standaryzowane wartości $j$-tej cechy w $i$-tym obiekcie,

$\bar{x}_{j}$ - średnia arytmetyczna $j$-tej cechy,

$s_{j}$ - odchylenie standardowe $j$-tej cechy,

$m$ - liczba zmiennych,

$n$ - liczba obiektów.

Po wyznaczeniu macierzy wejściowej wskaźników oraz standaryzacji ich wartości przechodzimy do wyznaczenia wzorca, którym jest punkt $P_{0} \mathrm{o}$ współrzędnych:

$$
x_{01}, x_{02}, x_{0 m}
$$

gdzie: 


$$
\begin{aligned}
& x_{0 j}=\max x_{i j} \text { jeśli } j \in I, \\
& x_{0 j}=\min x_{i j} \text { jeśli } j \notin I,
\end{aligned}
$$

gdzie:

$x_{i j}$ - zmienna standaryzowana,

$I$ - zbiór stymulant.

W celu obliczenia odległości euklidesowej między badanymi obiektami a wzorcem - punktem $P_{0}$, należy posłużyć się wzorem:

$$
d_{i 0}=\left[\sum_{j=1}^{m}\left(x_{i j}-x_{0 j}\right)^{2}\right]^{\frac{1}{2}} \quad j=1,2, \ldots, m
$$

Na podstawie wzoru (2.59) określamy miarę rozwoju:

$$
d_{i}^{\prime}=\frac{d_{i 0}}{d_{0}}
$$

gdzie:

$$
\begin{gathered}
d_{0}=\bar{d}_{0}+2 S_{0} \\
\bar{d}_{0}=\frac{1}{n} \sum_{i=1}^{n} d_{i 0}-\text { średnia arytmetyczna wartości } d_{i 0} \\
S_{0}=\left[\frac{1}{n} \sum_{i=1}^{n}\left(d_{i 0}-\bar{d}_{0}\right)^{2}\right]^{\frac{1}{2}}-\text { odchylenie standardowe odległości } \\
\text { od wzorca }
\end{gathered}
$$

Miara rozwoju $d_{i}^{\prime}$ jest nieujemna i tylko z prawdopodobieństwem zero przekracza wartość jeden. Oznacza to, że dana jednostka jest na tym wyższym poziomie rozwoju, im bardziej miara rozwoju jest bliższa zera. Tak zbudowaną miarę rozwoju najczęściej stosuje się w zmienionej postaci:

$$
d_{i}=1-\frac{d_{i 0}}{d_{0}}
$$

Wartości tego wskaźnika odpowiadające poszczególnym obiektom porządkujemy od wartości największej do najmniejszej. Obiekt jest tym bardziej rozwinięty, im wartość miary rozwoju zbliża się do jedności (Pluta 1977).

Do pomiaru poziomu rozwoju regionów wykorzystywana jest także metoda Perkala, która pozwala na uporządkowanie obiektów wielowymiarowych we- 
dług syntetycznego kryterium, które jest funkcją zmiennych wejściowych (Feltynowski, Nowakowska 2009).

Jednym ze sposobów normalizacji zmiennych jest standaryzacja, która w metodzie Perkala odbywa się analogicznie jak w metodzie Helwiga.

Syntetyczny wskaźnik zdolności innowacyjnej regionu Perkala $P_{i}$ jest wyrażony następującym wzorem:

$$
P_{i}=\frac{1}{m} \sum_{j=1}^{m} z_{i j}=\frac{1}{m} \sum_{j=1}^{m} \frac{x_{i j}-\bar{x}_{j}}{S_{j}}
$$

gdzie:

$z_{i j}$ - wartość zestandaryzowana cechy $j$ dla regionu $i$,

$m$ - liczba cech wchodzących w skład wskaźnika syntetycznego,

$j$ - numer wskaźnika w $i$-tym regionie.

\subsection{Metoda Wintersa}

Model Wintersa należy do klasy modeli wygładzania wykładniczego. Wygładzanie wykładnicze polega na tym, że szereg czasowy zmiennej prognozowanej wygładza się za pomocą ważonej średniej ruchomej, przy czym wagi są określone według prawa wykładniczego. Model Wintersa możemy stosować, gdy szereg czasowy zmiennej prognozowanej zawiera tendencję rozwojowa, wahania sezonowe i wahania przypadkowe. Zwracając uwagę na te założenia, podjęto próbę zastosowania tego modelu do prognozowania udziału wartości dodanej brutto w sektorze usług. Równania addytywnej wersji modelu są postaci (Cieślak 2001, s. 72):

$$
\begin{gathered}
F_{t-1}=\alpha\left(y_{t-1}-C_{t-1-r}\right)+(1-\alpha)\left(F_{t-2}-S_{t-2}\right) \\
S_{t-1}=\beta\left(F_{t-1}-F_{t-2}\right)+(1-\beta) S_{t-2} \\
C_{t-1}=\gamma\left(y_{t-1}-F_{t-1}\right)+(1-\gamma) C_{t-1-r}
\end{gathered}
$$

Równania multiplikatywnej wersji modelu:

$$
F_{t-1}=\alpha \frac{y_{t-1}}{C_{t-1-r}}+(1-\alpha)\left(F_{t-2}+S_{t-2}\right)
$$




$$
\begin{gathered}
S_{t-1}=\beta\left(F_{t-1}-F_{t-2}\right)+(1-\beta) S_{t-2} \\
C_{t-1}=\gamma \frac{y_{t-1}}{F_{t-1}}+(1-\gamma) C_{t-1-r}
\end{gathered}
$$

gdzie:

$F_{t-1}$ - odpowiednik wygładzonej wartości otrzymanej z prostego modelu wygładzania wykładniczego (ocena wartości średniej),

$S_{t-1}$ - ocena przyrostu trendu na moment lub okres $t-1$,

$C_{t-1}$ - ocena wskaźnika sezonowości na moment lub okres $t-1$,

$r$ - długość cyklu sezonowego - liczba faz,

$\alpha, \beta, \gamma$ - parametry modelu, przyjmujące wartości z przedziału $[0,1]$.

Równania prognozy:

$$
\begin{aligned}
& y_{t}^{*}=F_{n}+S_{n}(t-n)+C_{t-r}-\text { dla modelu addytywnego } \\
& y_{t}^{*}=\left[F_{n}+S_{n}(t-n)\right] C_{t-r}-\text { dla modelu multiplikatywnego }
\end{aligned}
$$

gdzie: $n<t$ jest liczbą wyrazów szeregu czasowego zmiennej prognozowanej.

Jeżeli poszczególne składowe szeregu czasowego ulegają szybkiej zmianie, to wartości parametrów wygładzania $\alpha, \beta, \gamma$ należy ustalić na poziomie bliskim jedności, w przeciwnym przypadku na poziomie bliskim zeru.

Za wartości początkowe $F_{1}, S_{1}$ i $C_{1}, \ldots, C_{r}$ można przyjąć odpowiednio (Cieślak 2001, s. 72):

- pierwszą wartość zmiennej prognozowanej, tj. y $y_{1}$ lub średnią z wartości zmiennej w pierwszym cyklu;

- różnicę drugiej i pierwszej wartości zmiennej prognozowanej, tj. $y_{2}-y_{1}$, lub różnicę średnich wartości zmiennej wyznaczonych dla drugiego i pierwszego cyklu;

- wyznaczoną na podstawie szeregu czasowego średnią różnic (dla modelu addytywnego) lub ilorazów (dla modelu multiplikatywnego), odpowiadających tej samej fazie cyklu sezonowego, wartości zmiennej prognozowanej i wygładzonych wartości trendu.

\subsection{Liniowe modele przestrzenne}


Większość procesów ekonomicznych ma charakter przestrzenny. Najczęściej wyróżnia się następujące rodzaje procesów przestrzennych (Haining 2003, Kopczewska 2010):

- dyfuzję, która ma miejsce, gdy określona cecha wprowadzona do populacji zawsze wystąpi u jakiejś jednostki tej populacji;

- wymiana i transfer, przepływ dóbr i usług skutkuje preferencjami lokalizacji pod względem jakiejś cechy (np. zatrudnienie w sektorze usług w województwie mazowieckim);

- interakcje, występują wówczas gdy wyniki procesów przestrzennych (np. ceny) jednej lokalizacji, poprzez mechanizm konkurencji zaczynają determinować wyniki w innej lokalizacji;

- rozproszenie, polega na migracji rozprzestrzenianiu się ludności, na co wskazuje wielkość subpopulacji (obszarów).

W przypadku spostrzeżenia, że modelowane procesy ekonomiczne nie są nie zależne od swojej lokalizacji wówczas należy zastosować metody uwzględniające czynnik przestrzenny. Takie podejście umożliwia kontrolowanie nielosowości reszt modeli ekonometrycznych a także pozwala uwzględnić efekty sąsiedztwa oraz odległości.

Do modelowania przestrzennego znajdują zastosowanie dwie podstawowe grupy modeli:

- modele błędu przestrzennego (spatial error model),

- modele opóźnienia przestrzennego (spatial lag model),

lub kombinacje powyższych modeli.

Model opóźnienia przestrzennego przyjmuje postać:

$$
y=\beta \mathbf{X}+\rho \mathbf{W} y+u \quad u \sim N(0,1)
$$

gdzie:

$\mathbf{X}$ - macierz zmiennych niezależnych,

$\rho$-współczynnik autokorelacji przestrzennej zmiennej objaśniającej $y$,

$\mathbf{W}$ - macierz wag przestrzennych,

$\beta$-wektor parametrów zmiennych egzogenicznych,

$y$ - wektor zmiennej zależnej,

$u$ - błąd modelu.

W modelu (2.74) testujemy hipotezę $H_{0}: \rho=0$, czyli istotności opóźnionej przestrzennie zmiennej zależnej. Parametry modelu (2.74) szacujemy metodą największej wiarygodności (MNW), (por. Anselin 1988).

Model błędu przestrzennego określony jest wzorem: 


$$
y=\beta \mathbf{X}+u, u=\lambda \mathbf{W} u+e, \quad e \sim N(0,1)
$$

gdzie oznaczenia są analogiczne jak w modelu (2.74), przy czym współczynnik autokorelacji przestrzennej jest oznaczony przez $\lambda$. W $u$ jest opóźnionym przestrzennie błędem, co należy interpretować jako średni błąd z lokalizacji sąsiedzkich a $e$ jest niezależnym błędem modelu.

W modelu (2.75) testujemy $H_{0}: \lambda=0$, czyli brak autokorelacji przestrzennej a parametr $\beta$ szacujemy metodą GLS, parametr $\lambda$ przez optymalizację. Można połączyć oba rozważane modele, wówczas model ogólnego procesu przestrzennego (general spatial process) przyjmuje postać:

$$
y=\rho \mathbf{W}_{1} y+\beta \mathbf{X}+u \text { gdzie } u=\lambda \mathbf{W}_{2} u+e
$$

W takim modelu (2.76) pojawia się problem identyfikacji równania (por. Anselin, 1988). Równość macierzy wag $\mathbf{W}_{1}, \mathbf{W}_{2}$ powoduje, że model nie jest zidentyfikowany, a model dwóch różnych macierzy wag powoduje również duże trudności. Stąd przyjmuje się do szacowanych parametrów modele niezagnieżdżone (non-nested-moddels) i weryfikuje się hipotezy dotyczące istotności $\rho$ lub $\lambda$, nie dopuszczając jednocześnie aby oba te współczynniki były jednocześnie różne od zera.

Do oceny autokorelacji przestrzennej najczęściej stosowana jest statystyka Morana (1948) określona wzorem:

$$
I=\frac{n \sum_{i} \sum_{k} w_{i k}\left(x_{i}-\bar{x}\right)\left(x_{k}-\bar{x}\right)}{\sum_{i} \sum_{k} w_{i k} \sum_{i}\left(x_{i}-\bar{x}\right)^{2}}
$$

gdzie:

$n$ - liczba obserwacji,

$w_{i k}$ - element macierzy wag,

$x_{i}$ - obserwacja badana,

$x_{k}-$ obserwacja sąsiedzka.

Statystyka (2.77) przyjmuje wartości z przedziału $(-1,1)$. Ujemne wielkości $I<0$ oznaczają silne zróżnicowanie przestrzenne, to znaczy, że regiony sąsiedzkie są zupełnie niepodobne. Natomiast gdy $I>0$ to oznacza, że są tworzone zgrupowania przestrzenne o podobnych warunkach. 



\section{POZIOM ROZWOJU SEKTORA USŁUG}

\subsection{Uwagi wstępne}

Proces transformacji ustroju gospodarczego w Polsce przyniósł wiele różnorodnych przemian, w tym przede wszystkim w sektorze usług.

Ocenę poziomu rozwoju sektora usług w Polsce ujęto zarówno globalnie, jak i w przekroju terytorialnym.

Najbardziej istotnym problemem rozwoju regionów w Polsce jest niski poziom aktywności ekonomicznej, który ma charakter strukturalny i wynika $\mathrm{z}$ bra$\mathrm{ku}$ przystosowania do potrzeb współczesnej gospodarki. W rozwoju sektora usług na poziomie lokalnym, regionalnym oraz krajowym szczególne znaczenie ma pomoc organów samorządowych, polegająca głównie na stwarzaniu dogodnych warunków dla rozwoju wybranych usług i sprawowaniu pieczy nad ich rozwojem, stymulowaniu i zachęcaniu podmiotów gospodarczych do podnoszenia jakości oferowanych usług oraz stymulowaniu rozwoju infrastruktury społecznej i ekonomicznej dla rozwoju usług. Odpowiednia polityka regionalna może istotnie wpływać na przyspieszenie rozwoju gospodarczego kraju.

Poprzez analizę sektora usług w ujęciu zarówno regionalnym, jak i krajowym wykazano znaczenie polityki regionalnej i jej wpływ na rozwój polskiej gospodarki.

Porównanie podstawowych wskaźników wykorzystywanych do określania poziomu rozwoju społeczno-gospodarczego uwzględniających między innymi liczbę pracujących oraz wartość dodaną brutto w układzie trójsektorowym w Polsce z innymi państwami Unii Europejskiej pozwala na ocenę polskiej gospodarki. W wysoko rozwiniętych państwach Unii Europejskiej obserwowane są znaczne przeobrażenia trójsektorowej struktury gospodarczej, które prowadzą do zmniejszania się udziału sektora rolnego i przemysłowego na rzecz sektora usług. W celu zbadania, czy działania polskiej gospodarki zmierzają w podobnym kierunku, porównano udział wartości dodanej brutto i pracujących z państwami Unii Europejskiej w analizowanych sektorach. 


\subsection{Sektor usług na tle innych sektorów}

Podział gospodarki na trzy sektory niejednokrotnie budzi pewne wątpliwości ze względu brak ostrości podziału sektorów i przenikania sektora usług do pozostałych sektorów. Podział taki pozwala jednak na uchwycenie pewnych zmian, dokonujących się w strukturze gospodarki oraz umożliwia ocenę roli sektora usług. Polska gospodarka znajduje się w stanie, w którym działalność produkcyjna i działalność usługowa współistnieją obok siebie, warunkują swój rozwój i wzajemnie się przenikają. Rozwój jest określany jako długotrwały proces kierunkowych zmian, w którym można wyodrębnić prawidłowo po sobie następujące etapy przemian, wykazujące zróżnicowanie pod względem określonych cech. Chojnicki (1989) rozwój określa jako ciąg zmian o długotrwałym charakterze, który składa się z faz, stadiów i etapów. Karpiński (1986) uważa, że im głębsze są zmiany struktury, tym szybsze jest tempo rozwoju. Czerwińska (2003, s. 2) twierdzi, że „tempo wzrostu gospodarczego jest uwarunkowane taką strukturą gospodarki, w której duży jest udział dziedzin dynamizujących gospodarkę: w krótkim okresie dzięki działaniu czynników popytowych (wewnętrznych i zewnętrznych), w długim okresie - poprzez wysoki udział gałęzi o najwyższej technice i technologii wytwarzania". Rozwój regionu jest kategorią mierzalną, nie mniej jednak ze względu na złożony charakter zjawisk społecznogospodarczych, występujących w procesach rozwoju poszczególnych regionów, jest trudny do wyrażenia za pomocą jednego miernika. Wymagane jest więc stosowanie różnych mierników odzwierciedlających wszystkie istotne cechy, pozwalające na dokonanie oceny badanego regionu (Szymala 2000). Na potrzeby przeprowadzanych analiz przyjęto trójsektorową strukturę gospodarki zgodną z koncepcją Fishera, Clarka oraz Fourastiégo wyróżniającą sektor I (rolniczy), sektor II (przemysłowy) oraz sektor III (usługowy). Przyjęto także, że rozwój sektora usług jest związany ze spadkiem udziału sektora rolnego i przemysłowego w liczbie pracujących, wartości dodanej brutto oraz liczbie podmiotów gospodarczych.

Na dynamiczny rozwój sektora usług ma wpływ wiele różnych czynników, do których można zaliczyć (por. Lotko 2009):

- wzrost poziomu zamożności społeczeństw i zwiększającej się ilości czasu wolnego;

- złożoność dóbr i usług wymagająca szczegółowej informacji w postaci np. instrukcji, doradztwa, szkolenia;

- dążenie społeczeństwa do podnoszenia kwalifikacji i poziomu wykształcenia oraz wzrost oczekiwań społecznych;

- postęp technologiczny, który jest odpowiedzialny za powstawanie nowych rodzajów usług i nowych zawodów;

- przenikanie sektora usług do pozostałych dwóch sektorów. 
$\mathrm{Na}$ dominującą rolę sektora usługowego wskazuje analiza zachodzących zmian w układzie trójsektorowym. Rozwój sektora usług oznacza nie tylko ilościowy wzrost tego rodzaju aktywności ekonomicznej, ale i wewnętrzne zmiany strukturalne zachodzące w jego obrębie. Poziom rozwoju sektora usług oceniany jest powszechnie poprzez pomiar jego udziału w zatrudnieniu oraz w tworzeniu wartości dodanej brutto z uwzględnieniem kierunków aktywności podmiotów gospodarczych. Obserwacja zachowań przedsiębiorstw dostarcza informacji o kierunkach zmian w procesach rozwoju. Uważa się, że rozwój sektora usług oznacza wzrastający jego udział w strukturze zatrudnienia, wartości dodanej i podmiotów gospodarczych. Struktura zatrudnienia jest jednym z podstawowych mierników poziomu rozwoju społeczno-gospodarczego stosowanych w naukach ekonomicznych. Według Kwiatkowskiej (2007, s. 25) zmiany strukturalne zachodzące na rynku pracy są obiektywnym procesem występującym w gospodarce rynkowej, ponieważ są następstwem naturalnych zmian systemu gospodarczego, który jest wrażliwy na zmieniające się preferencje nabywców oraz wykazuje dużą podatność na zmiany w procesie produkcji.

Sadler (1997), podkreślając ciągły wzrost zatrudnienia w sektorze usług w państwach uprzemysłowionych, podaje powody wzrostu i spadku popytu na pracę w sektorze usług (por. także Kłosiński 2011). Według Sadlera popyt na pracę w usługach rośnie, gdy społeczeństwo staje się bogatsze i standard życiowy wzrasta. Wyższe dochody sprawiają że społeczeństwo zaczyna korzystać z szerszej oferty rynku usług, a skoro wzrasta popyt na usługi, to przedsiębiorstwa usługowe zwiększają zapotrzebowanie na nowych pracowników. Rozpiętość, a także jakość usług świadczonych przez państwo zwiększa się proporcjonalnie do wzrostu gospodarczego, nowe towary konsumpcyjne i technologie przyczyniają się do powstania nowych rodzajów usług i stymulują rozwój już istniejących usług. Natomiast popyt na zatrudnienie w usługach maleje pod wpływem wypierania z rynku niektórych usług ze względu na wzrost poziomu płac oraz posiadanie tzw. konsumenckich środków trwałych; przykładem może być posiadanie własnego samochodu, które wpływa na ograniczenie publicznych środków transportu. Spadku popytu należy także upatrywać w braku zainteresowania usługami naprawczymi, wynikającego z relacji ceny naprawy do ceny zakupu nowej rzeczy (np. usługi szewskie, krawieckie, naprawa sprzętu RTV) oraz wzroście produktywności wyprzedzającym wzrost popytu na dane usługi. Porównanie struktury pracujących w układzie trzech sektorów zwraca uwagę na występujące w tym obszarze różnice. Zgodnie z klasyfikacją GUS informacje o pracujących dotyczą osób wykonujących pracę przynoszącą im zarobek lub dochód. Do osób pracujących zalicza się: osoby zatrudnione na podstawie stosunku pracy lub stosunku służbowego, pracodawców i pracujących na własny rachunek, osoby wykonujące pracę nakładczą, poza tym agentów, członków spółdzielni produkcji rolniczej oraz duchownych pełniących obowiązki duszpasterskie (por. Pracujący w gospodarce narodowej w 2009 r). 
Polska po poprzednim systemie odziedziczyła niski udział usług w tworzeniu dochodu narodowego i w ogólnym poziomie zatrudnienia w gospodarce.

Początek intensywnych zmian $\mathrm{w}$ polskiej gospodarce jest wiązany $\mathrm{z}$ rokiem 1989, niemniej ze względu na lepsze możliwości porównawcze związane ze zmianą PKD 2004 na PKD 2007 w analizach rynku usług skupiono się głównie na danych statystycznych z lat 2005-2010. W niektórych przypadkach analizie poddano okres dłuższy lub krótszy, a było to uwarunkowane przeliczeniem przez GUS informacji statystycznych według nowego systemu PKD.

Rynek pracy w Polsce od początku lat dziewięćdziesiątych przechodził głębokie przeobrażenia pod względem liczby osób pracujących. Proces ten był bardzo zróżnicowany w czasie w poszczególnych sektorach gospodarki. Na zachodzące zmiany miały wpływ procesy rozwoju gospodarczego, transformacja systemowa oraz integracja z Unią Europejską (Kwiatkowski, Kucharski 2010). W pierwszych latach okresu transformacji miał miejsce spadek liczby pracujacych i wzrost bezrobocia. W roku 1994 wskaźnik zatrudnienia wyniósł 58,3\%, a stopa bezrobocia $14,8 \%$. Pewną poprawę na rynku pracy zanotowano w następnym okresie transformacji, tj. w latach 1995-1998. Liczba pracujących wzrosła, zaś stopa bezrobocia spadła do 10,8 \%. Do silnych zmian na rynku pracy doszło w następnym okresie przemian, w roku 1999 poziom zatrudnienia spadł do $54,9 \%$, a stopa bezrobocia wzrosła, osiagając poziom $16,4 \%$. W latach 2001-2002 zatrudnienie ponownie uległo spadkowi o 3,5 punktów procentowych, zaś stopa bezrobocia wzrosła w 2003 roku do 20,1\%. Na przełomie lat 2002-2003 doszło do ustabilizowania się sytuacji na rynku pracy (Bukowski 2005). W okresie transformacji gospodarki zgodnie $\mathrm{z}$ wymogami rozwoju gospodarczego i poprawy konkurencyjności gospodarki doszło do korzystnych zmian $\mathrm{w}$ trójsektorowej strukturze pracujących, zmniejszył się udział sektora rolniczego w ogólnej liczbie pracujących, podobne choć znacznie słabsze zmiany zaszły w przemyśle, natomiast w sektorze usługowym doszło do zwiększenia udziału pracujących. Zachodzące $w$ gospodarce przeobrażenia, prowadzące do powstania gospodarki opartej na usługach, wywołują istotne zmiany na rynku pracy, wpływają na charakter i treść pracy, zatrudnienie i jego strukturę, kwalifikacje pracowników, zmianę charakteru zawodów, zanikanie starych oraz powstawanie nowych zawodów oraz organizację pracy. Istotny jest także wpływ zachodzących procesów na system nauki i oświaty, od którego wymaga się szybkiej reakcji i dostosowania do potrzeb rynku (por. Lichniak 2010).

Jednym ze wspomnianych wcześniej mierników pozwalającym ocenić strukturę jest zatrudnienie. Sektorowa struktura zatrudnienia odzwierciedla dojrzałość gospodarki, natomiast liczba zatrudnionych w sektorze usług pokazuje jego zdolność do obsługi konsumentów. Struktura pracujących według trzech sektorów gospodarki w latach 1994-2011 przedstawiona została w tab.3.1 oraz na rys. 3.1. 
Tablica 3.1.Trójsektorowa struktura pracujących w Polsce

\begin{tabular}{|c|c|c|c|c|c|c|c|}
\hline Rok & $\begin{array}{c}\text { Pracujący } \\
\text { (w tys.) }\end{array}$ & $\begin{array}{c}\text { Sektor } \\
\text { rolniczy } \\
\text { (w tys.) }\end{array}$ & $\begin{array}{c}\text { Udział \% } \\
\text { sektora } \\
\text { rolniczego }\end{array}$ & $\begin{array}{c}\text { Sektor } \\
\text { przemys. } \\
\text { (w tys.) }\end{array}$ & $\begin{array}{c}\text { Udział \% } \\
\text { sektora } \\
\text { przemys. }\end{array}$ & $\begin{array}{c}\text { Sektor } \\
\text { usługowy } \\
\text { (w tys.) }\end{array}$ & $\begin{array}{c}\text { Udział \% } \\
\text { sektora } \\
\text { usługowego }\end{array}$ \\
\hline 1994 & 14924,0 & 4054,4 & 27,17 & 4570,0 & 30,62 & 6299,6 & 42,21 \\
\hline 1995 & 15129,1 & 4207,1 & 27,81 & 4556,2 & 30,12 & 6365,8 & 42,08 \\
\hline 1996 & 15487,4 & 4371,5 & 28,23 & 4626,0 & 29,86 & 6489,9 & 41,90 \\
\hline 1997 & 15940,8 & 4377,9 & 27,46 & 4708,8 & 29,54 & 6854,1 & 43,00 \\
\hline 1998 & 15921,1 & 4356,1 & 27,36 & 4588,6 & 28,82 & 6976,4 & 43,81 \\
\hline 1999 & 16008,9 & 4334,0 & 27,07 & 4341,6 & 27,12 & 7016,1 & 43,83 \\
\hline 2000 & 15488,8 & 4314,9 & 27,86 & 3949,0 & 25,50 & 7224,9 & 46,65 \\
\hline 2001 & 14995,6 & 4296,8 & 28,65 & 3700,7 & 24,68 & 6998,1 & 46,67 \\
\hline 2002 & 14923,7 & 4287,8 & 28,73 & 3564,5 & 23,88 & 7071,4 & 47,38 \\
\hline 2003 & 12640,7 & 2144,6 & 16,96 & 3488,9 & 27,60 & 7007,2 & 55,43 \\
\hline 2004 & 12720,2 & 2145,1 & 16,86 & 3519,7 & 27,67 & 7055,4 & 55,46 \\
\hline 2005 & 12890,7 & 2134,1 & 16,56 & 3519,1 & 27,30 & 7237,5 & 56,15 \\
\hline 2006 & 13220,0 & 2134,6 & 16,15 & 3684,9 & 27,87 & 7400,5 & 55,98 \\
\hline 2007 & 13771,1 & 2138,2 & 15,53 & 3907,7 & 28,38 & 7725,2 & 56,10 \\
\hline 2008 & 14037,2 & 2128,3 & 15,16 & 3938,7 & 28,06 & 7970,2 & 56,78 \\
\hline 2009 & 13782,3 & 2124,9 & 15,42 & 3774,5 & 27,39 & 7882,9 & 57,20 \\
\hline 2010 & 14106,9 & 2376,1 & 16,84 & 3774,7 & 26,76 & 7956,1 & 56,40 \\
\hline 2011 & 14145,0 & 2375,5 & 16,79 & 3801,4 & 26,87 & 7968,1 & 56,33 \\
\hline
\end{tabular}

Źródło: obliczenia własne na podstawie Rocznika Statystycznego Rzeczypospolitej Polskiej 1997, 2000, 2001, 2005, 2008, 2011; Mały Rocznik Statystyczny Polski 2012.
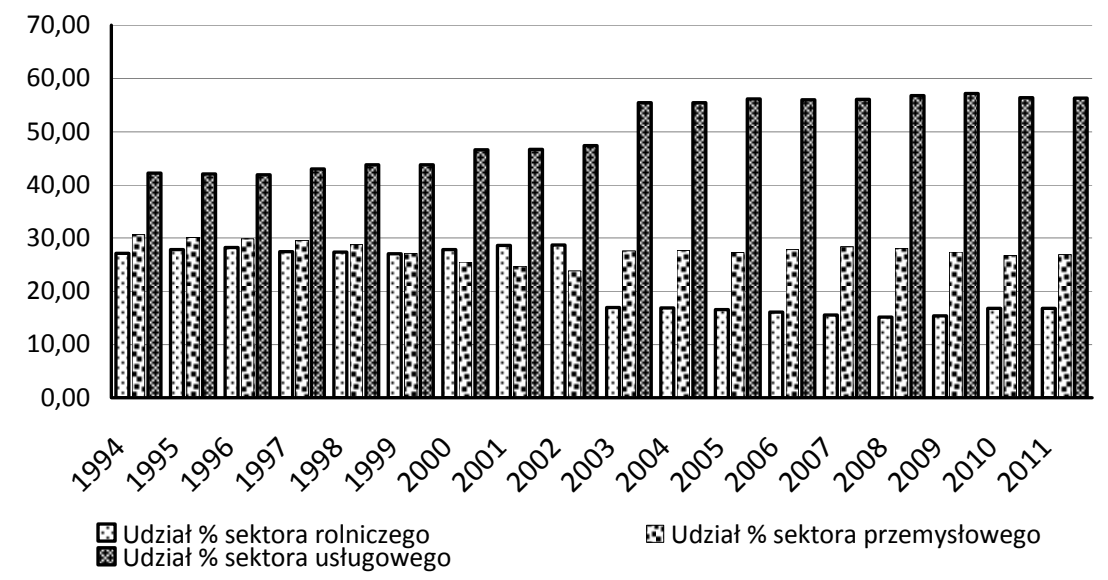

Rys. 3.1. Trójsektorowa struktura pracujących w gospodarce

Źródło: opracowanie własne na podstawie Rocznika Statystycznego Rzeczypospolitej Polskiej 1997, 2000, 2001, 2005, 2008, 2011; Mały Rocznik Statystyczny Polski 2012. 
W latach 1994-2011 nastapiły istotne zmiany w liczbie osób pracujących w gospodarce. Na podstawie tablicy 3.1 obserwujemy dominującą rolę sektora usług w poziomie zatrudnienia. W sektorze rolnym w badanym okresie doszło do spadku liczby pracujących z 27\% w 1994 r. do około 16\% w roku 2011. Zmniejszenie udziału zatrudnionych $\mathrm{w}$ rolnictwie $\mathrm{i}$ wzrost $\mathrm{w}$ usługach jest jednym z symptomów rozwoju gospodarki. Sektor przemysłowy nie wykazał aż tak istotnych zmian jak sektor rolny. W roku $1994 \mathrm{w}$ przemyśle pracowało 30,6\%, natomiast w 2011 było to $26,8 \%$. Analiza danych pozwala stwierdzić, że sektor usług jest głównym źródłem miejsc pracy. W roku 2005 w sektorze rolnym i przemysłowym łącznie było zatrudnionych $43,85 \%$ ogółu pracujących w gospodarce, w sektorze usług w tym samym okresie pracowało $56,15 \%$ ogółu zatrudnionych $\mathrm{w}$ gospodarce. Podobnie było w następnych latach. Najbardziej prawdopodobnym czynnikiem wzrostu liczby osób pracujących w usługach był przepływ z pozostałych sektorów gospodarki. Mają na to wpływ także nowe formy zatrudniania pracowników np. „samo zatrudnienie”, telepraca, umowy agencyjne. Przyczyn dominacji zatrudnionych w sektorze trzecim gospodarki należy także upatrywać we wzroście zamożności społeczeństwa, a w konsekwencji we wzroście popytu na usługi. Poza tym dzięki postępowi technicznemu pojawiają się nowe rodzaje usług, które dostarczają nowych miejsc pracy. Sektor usługowy posiada zdolność absorbowania nadwyżek siły roboczej, co sprzyja łagodzeniu zmniejszaniu poziomu bezrobocia. Do czynników wpływających na zatrudnienie w usługach należy zaliczyć (Okulas 1998):

- większą pewność utrzymania pracy w małych firmach przy zmieniających się warunkach gospodarczych;

- potrzebę posiadania wszechstronnych zdolności, ułatwiających poznanie reguł funkcjonowania firmy na rynku oraz zachęcanie do podjęcia własnej działalności tworzącej nowe miejsca pracy;

- możliwość podejmowania pracy w niepełnym wymiarze godzin.

Wyodrębniając czynniki sprzyjające zatrudnieniu w trzecim sektorze, należy także zwrócić uwagę na te, które ograniczają możliwości zatrudnienia w sektorze usług. Głównym czynnikiem ograniczającym jest tu pozom kwalifikacji, który wymaga ciagłego dokształcania w celu podnoszenia jakości oferowanych usług.

Analizując poziom zatrudnienia w poszczególnych sektorach gospodarki, warto podkreślić fakt, że w okresie spowolnienia gospodarczego sektor rolny odgrywa w Polsce rolę bufora amortyzującego negatywne zmiany na rynku pracy (www.ibs.org.pl). Osoby tracące pracę i niemogące znaleźć zatrudnienia w przemyśle bądź usługach z przyczyn koniecznych podejmują pracę w rodzinnych gospodarstwach rolnych. Zjawisko to posiada jednak dwa oblicza, jedno będące zabezpieczeniem przed bezrobociem, drugie związane $\mathrm{z}$ nadmiernym 
zatrudnieniem w sektorze rolnym i zatrzymywaniem dodatkowych sił roboczych w tym sektorze, co można określić jako bezrobocie ukryte.

Przejdziemy teraz do omówienia problemu dotyczącego oceny udziału poszczególnych sektorów w rozwoju gospodarczym Polski między innymi zmiany wartości dodanej brutto, co stanowi jeden z głównych celów rozprawy. Pogłębiona analiza tego problemu zostanie przedstawiona na podstawie informacji statystycznych z różnych dostępnych źródeł obejmujących lata 1994-2011. Podstawowe informacje zawierające strukturę wartości dodanej brutto generowanych przez poszczególne sektory zawarte są w tablicy 3.2.

Tablica 3.2. Wartość dodana brutto według sektorów gospodarki w latach 1994-2011

\begin{tabular}{|c|c|c|c|c|c|c|c|}
\hline Rok & $\begin{array}{c}\text { Wartość } \\
\text { dodana brutto } \\
\text { ogółem }\end{array}$ & $\begin{array}{c}\text { Sektor } \\
\text { rolniczy }\end{array}$ & $\begin{array}{c}\text { Udział \% } \\
\text { sektora } \\
\text { rolniczego }\end{array}$ & $\begin{array}{c}\text { Sektor } \\
\text { przemysłowy }\end{array}$ & $\begin{array}{c}\text { Udział \% } \\
\text { sektora } \\
\text { przemy- } \\
\text { słowego }\end{array}$ & $\begin{array}{c}\text { Sektor } \\
\text { usługowy }\end{array}$ & $\begin{array}{c}\text { Udział \% } \\
\text { sektora } \\
\text { usługowego }\end{array}$ \\
\hline 1994 & 179716 & 13353 & 7,43 & 71564 & 39,82 & 94799 & 52,75 \\
\hline 1995 & 268289 & 18560 & 6,92 & 104467 & 38,94 & 145262 & 54,14 \\
\hline 1996 & 336854 & 21646 & 6,43 & 126332 & 37,50 & 188876 & 56,07 \\
\hline 1997 & 412870 & 22771 & 5,52 & 153794 & 37,25 & 236305 & 57,23 \\
\hline 1998 & 485177 & 23097 & 4,76 & 175952 & 36,27 & 278411 & 57,38 \\
\hline 1999 & 535829 & 20991 & 3,92 & 192306 & 35,89 & 323268 & 60,33 \\
\hline 2000 & 662468 & 32832 & 4,96 & 209975 & 31,70 & 419661 & 63,35 \\
\hline 2001 & 694896 & 35459 & 5,10 & 204854 & 29,48 & 454583 & 65,42 \\
\hline 2002 & 714353 & 32300 & 4,52 & 205135 & 28,72 & 476918 & 66,76 \\
\hline 2003 & 743321 & 32699 & 4,40 & 220035 & 29,60 & 490587 & 66,00 \\
\hline 2004 & 816515 & 41720 & 5,11 & 252475 & 30,92 & 522320 & 63,97 \\
\hline 2005 & 866329 & 39235 & 4,53 & 266043 & 30,71 & 561051 & 64,76 \\
\hline 2006 & 931179 & 39930 & 4,29 & 289680 & 31,11 & 601569 & 64,60 \\
\hline 2007 & 1027631 & 44514 & 4,33 & 327176 & 31,84 & 655941 & 63,83 \\
\hline 2008 & 1116476 & 41698 & 3,73 & 352109 & 31,54 & 722669 & 64,73 \\
\hline 2009 & 1193982 & 43513 & 3,64 & 379227 & 31,76 & 771242 & 64,59 \\
\hline 2010 & 1246427 & 46905 & 3,76 & 398644 & 31,98 & 800879 & 64,25 \\
\hline 2011 & 1338990 & 48260 & 3,60 & 446516 & 33,35 & 844273 & 63,05 \\
\hline
\end{tabular}

Źródło: obliczenia własne na podstawie Rocznika Statystycznego Rzeczypospolitej Polskiej 1997, 2000, 2001, 2005, 2008, 2011; Mały Rocznik Statystyczny Polski 2012.

W Polsce w badanym okresie obserwuje się na ogół wzrost znaczenia sektora usług poprzez zwiększenie się udziału wartości dodanej brutto generowanej przez ten sektor (por. także rys. 3.2). 


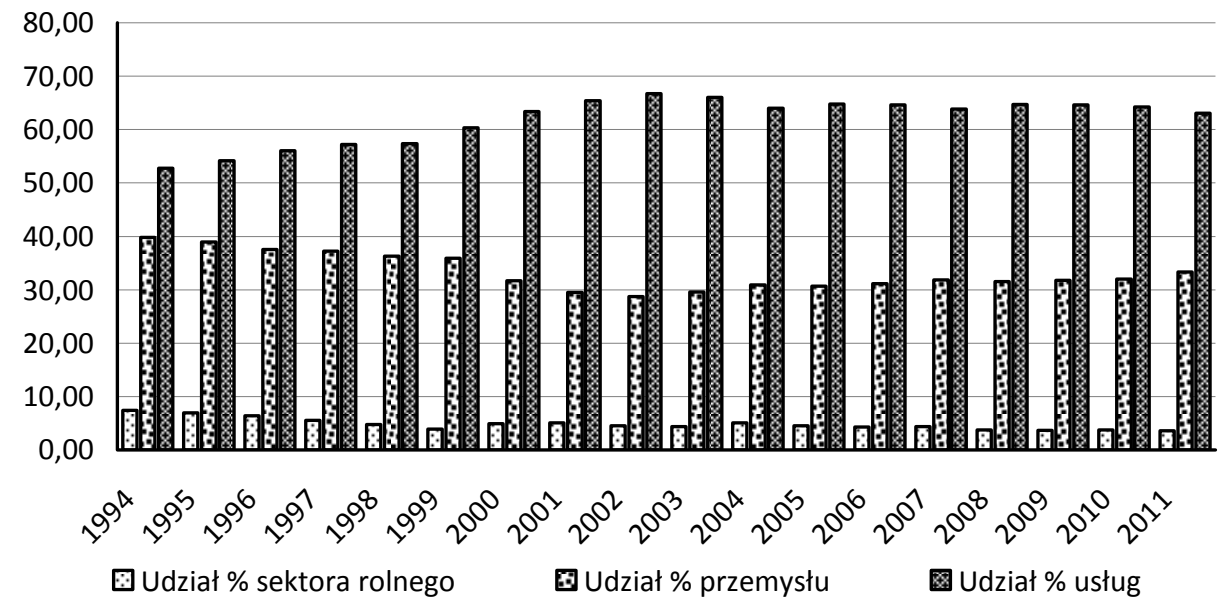

Rys. 3.2. Wartość dodana brutto według sektorów gospodarki

Źródło: opracowanie własne na podstawie Rocznika Statystycznego Rzeczypospolitej Polskiej 1997, 2000, 2001, 2005, 2008, 2011; Mały Rocznik Statystyczny Polski 2012.

Oceniając zmiany zachodzące $\mathrm{w}$ gospodarce pod względem wytwarzanej wartości dodanej brutto w trzech sektorach gospodarki, najbardziej dynamicznymi były: przemysł i usługi. Według danych GUS w latach 1995-2005 udział rolnictwa, łowiectwa i leśnictwa w wytwarzaniu wartości dodanej brutto zmniejszył się z 8 do 4,5\%, a przemysłu odpowiednio z 28,4 do 24,9\% (Mały Rocznik Statystyczny Polski 2006, s. 454). Spadek udziału tych dwóch sektorów gospodarki w wytwarzaniu wartości dodanej brutto był wynikiem wyższego tempa wzrostu produkcji w sektorze usług. W latach 2005-2010 sektor usług wytworzył około 65\% wartości dodanej całej gospodarki, wyjątkiem był rok 2007, w którym udział sektora był niższy i wynosił $63,83 \%$.

Analiza danych dotyczących pracujących i wartości dodanej brutto w układzie sektorowym pozwoliła sformułować następujące wnioski:

- nastąpił wzrost udziału dominującego w gospodarce sektora usługowego, udział wartości dodanej brutto wzrósł z 52,7\% w 1994 r. do ok. 63\% w 2011 r., w przypadku pracujących zwiększył się z 42\% w 1994 r. do 56\% w 2011r.;

- udział sektora przemysłowego ustabilizował się na poziomie ok. 32\% w przypadku wartości dodanej brutto i ok. $27 \%$ w liczbie pracujących;

- znacznie zmniejszył się udział sektora rolniczego zarówno w wartości dodanej brutto, jak i liczbie pracujących, w przypadku pracujących obserwujemy spadek z 7,4\% w 1994 r. do 3,6\% w 2011 i wartości dodanej brutto z 27\% w 1994 r. do ok. 16\% w 2011 r.; 
- zmiany w strukturze pracujących w każdym z trzech sektorów charakteryzowały się inną strukturą, najbardziej zmniejszył się udział pracujących w sektorze rolnym.

O dominacji sektora usług świadczy także udział podmiotów gospodarczych zarejestrowanych w REGON-ie, w sektorze usług na tle podmiotów w innych sektorach (tab. 3.3).

Tablica 3.3. Podmioty gospodarki narodowej zarejestrowane w rejestrze REGON według sektorów gospodarki w latach 2005-2011

\begin{tabular}{|c|c|c|c|c|c|c|c|}
\hline Rok & $\begin{array}{c}\text { Podmioty } \\
\text { ogółem }\end{array}$ & $\begin{array}{c}\text { Sektor } \\
\text { rolniczy }\end{array}$ & $\begin{array}{c}\text { Udział \% } \\
\text { sektora } \\
\text { rolniczego }\end{array}$ & $\begin{array}{c}\text { Sektor } \\
\text { przemy- } \\
\text { słowy }\end{array}$ & $\begin{array}{c}\text { Udział \% } \\
\text { sektora } \\
\text { przemy- } \\
\text { słowego }\end{array}$ & $\begin{array}{c}\text { Sektor } \\
\text { usługowy }\end{array}$ & $\begin{array}{c}\text { Udział \% } \\
\text { sektora } \\
\text { usługowego }\end{array}$ \\
\hline 2005 & 3615621 & 88762 & 2,45 & 741605 & 20,51 & 2785254 & 77,03 \\
\hline 2006 & 3636039 & 91657 & 2,52 & 748642 & 20,59 & 2795740 & 76,89 \\
\hline 2007 & 3685608 & 94091 & 2,55 & 774301 & 21,01 & 2817216 & 76,44 \\
\hline 2008 & 3757093 & 95608 & 2,54 & 804181 & 21,40 & 2857304 & 76,05 \\
\hline 2009 & 3742673 & 87932 & 2,35 & 805215 & 21,51 & 2849526 & 76,14 \\
\hline 2010 & 3909802 & 92537 & 2,36 & 846795 & 21,65 & 2970470 & 75,97 \\
\hline 2011 & 3869897 & 93167 & 2,41 & 836434 & 21,61 & 2940055 & 75,97 \\
\hline
\end{tabular}

Źródło: obliczenia własne na podstawie Rocznika Statystycznego Rzeczypospolitej Polskiej 2006, 2008, 2011, Banku Danych Lokalnych.

Do rejestru REGON wpisywane są podmioty gospodarki narodowej, tzn. osoby prawne, jednostki organizacyjne nieposiadające osobowości prawnej, osoby fizyczne prowadzące działalność gospodarczą oraz zgłoszone przez jednostkę prawną jednostki lokalne. Celem prowadzenia rejestru REGON jest identyfikacja podmiotów gospodarki narodowej w sposób jednoznaczny i niepowtarzalny, co jest realizowane poprzez nadawanie im numerów identyfikacyjnych REGON. Rejestr REGON na podstawie wniosków zgłaszanych przez jednostki prawne podlega bieżącej aktualizacji. W roku 2005 udział przedsiębiorstw zarejestrowanych w sektorze usług przekroczył $77 \%$, w następnych latach udział ten utrzymywał się na równie wysokim poziomie. W 2010 r. wśród 3,9 mln podmiotów gospodarczych ponad $2,9 \mathrm{mln}$ podmiotów stanowiły przedsiębiorstwa o charakterze usługowym, co stanowiło ok. $76 \%$ ogółu podmiotów. Udział podmiotów sektora rolnego jest minimalny, natomiast udział podmiotów w sektorze przemysłu kształtuje się niezmiennie na poziomie ok. 21\%. W 2011 r. udział podmiotów gospodarczych w poszczególnych sektorach pozostawał na podobnym poziomie jak w $2010 \mathrm{r}$. Interesująca jest także szersza analiza podmiotów gospodarczych, polegająca na ich obserwacji w dłuższym okresie, uwzględniająca ich aktywność (por. tab.3.4 i rys. 3.3). 


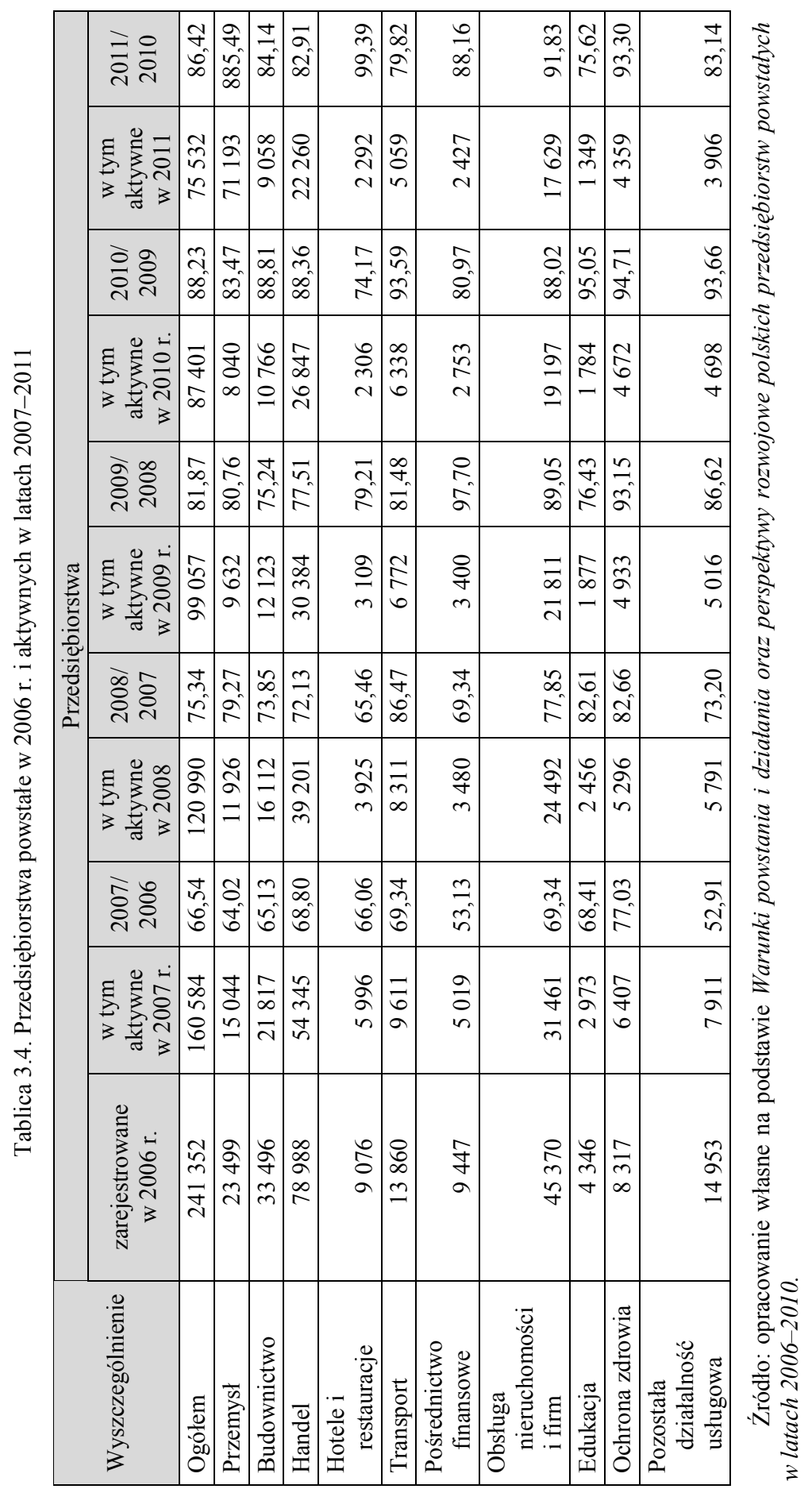




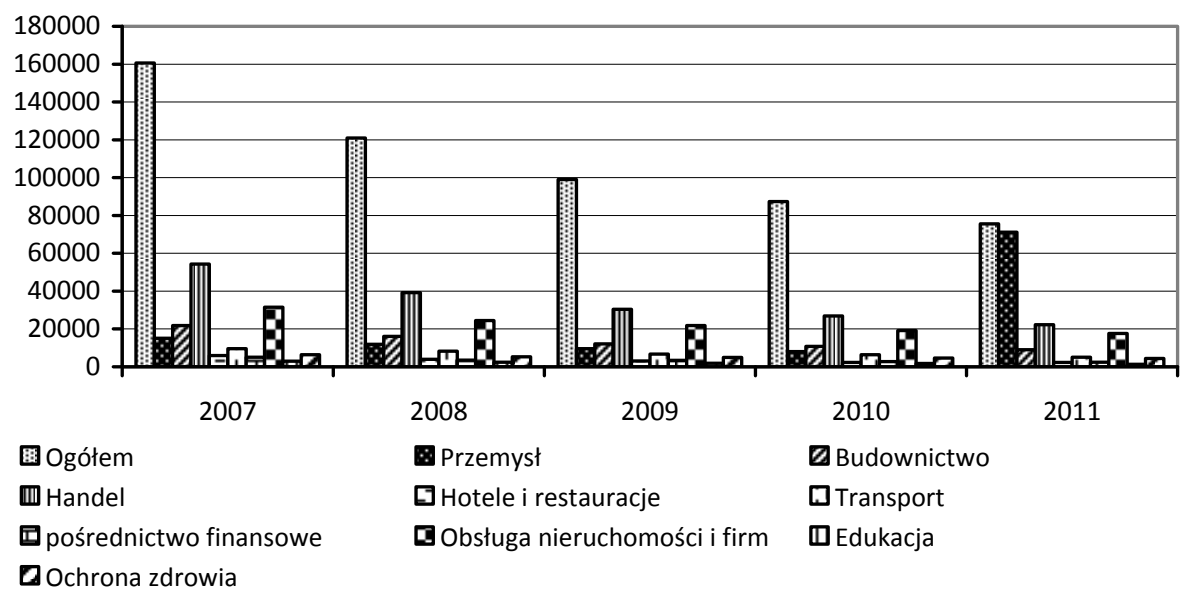

Rys. 3.3. Przedsiębiorstwa powstałe w 2006 r. i aktywne w latach 2007-2011

Źródło: opracowanie własne na podstawie Warunki powstania i działania oraz perspektywy rozwojowe polskich przedsiębiorstw powstatych w latach 2006-2010.

Proces transformacji gospodarczej w Polsce przyniósł wiele zmian na rynku pracy. W tab. 3.5 przedstawiono dynamikę pracujących według sektorów gospodarki w latach 1994-2011. Średniookresowe tempo spadku przeciętnej liczby pracujących $\mathrm{w}$ Polsce $\mathrm{w}$ latach $1994-2011$ wyniosło $0,3 \%$ rocznie, przy czym dla sektora rolniczego wynosiło $3,1 \%$, a dla przemysłu $1,1 \%$. W sektorze usług zaobserwowano wzrost pracujących średnio o $1,4 \%$ rocznie.

$\mathrm{W}$ polskiej gospodarce sektor usług odgrywa istotną rolę $\mathrm{w}$ poziomie zatrudnienia. Analizując zmiany pracujących według sektorów gospodarki w latach 1994-2011, najlepiej przedstawia się sytuacja w sektorze usług, w którym nastąił wzrost zatrudnienia o $26,5 \%$. W analizowanym okresie zaobserwowano jednak niewielki spadek zatrudnienia w tym sektorze w latach 2001, 2003 i 2009. Począwszy od roku 2006, w kolejnych latach następował wzrost liczby pracujących $\mathrm{w}$ stosunku do roku poprzedniego odpowiednio o: $2,5 \%, 4,1 \%$, 1,9\%. W roku 2009 został odnotowany spadek o 1,9\%, a w 2010 r. wzrost o 2,35\%. W roku 2010 sektor usług dał miejsca pracy dla 56,39\% ogółu zatrudnionych. Zwiększająca się liczba pracujących w usługach jest jedną $\mathrm{z}$ prawidłowości przekształceń strukturalnych w gospodarce i wynika z rosnącego popytu na różnego rodzaju usługi.

$\mathrm{W}$ tab. 3.6 przedstawiono dynamikę wartości dodanej brutto według sektorów gospodarki w latach 1994-2011. 


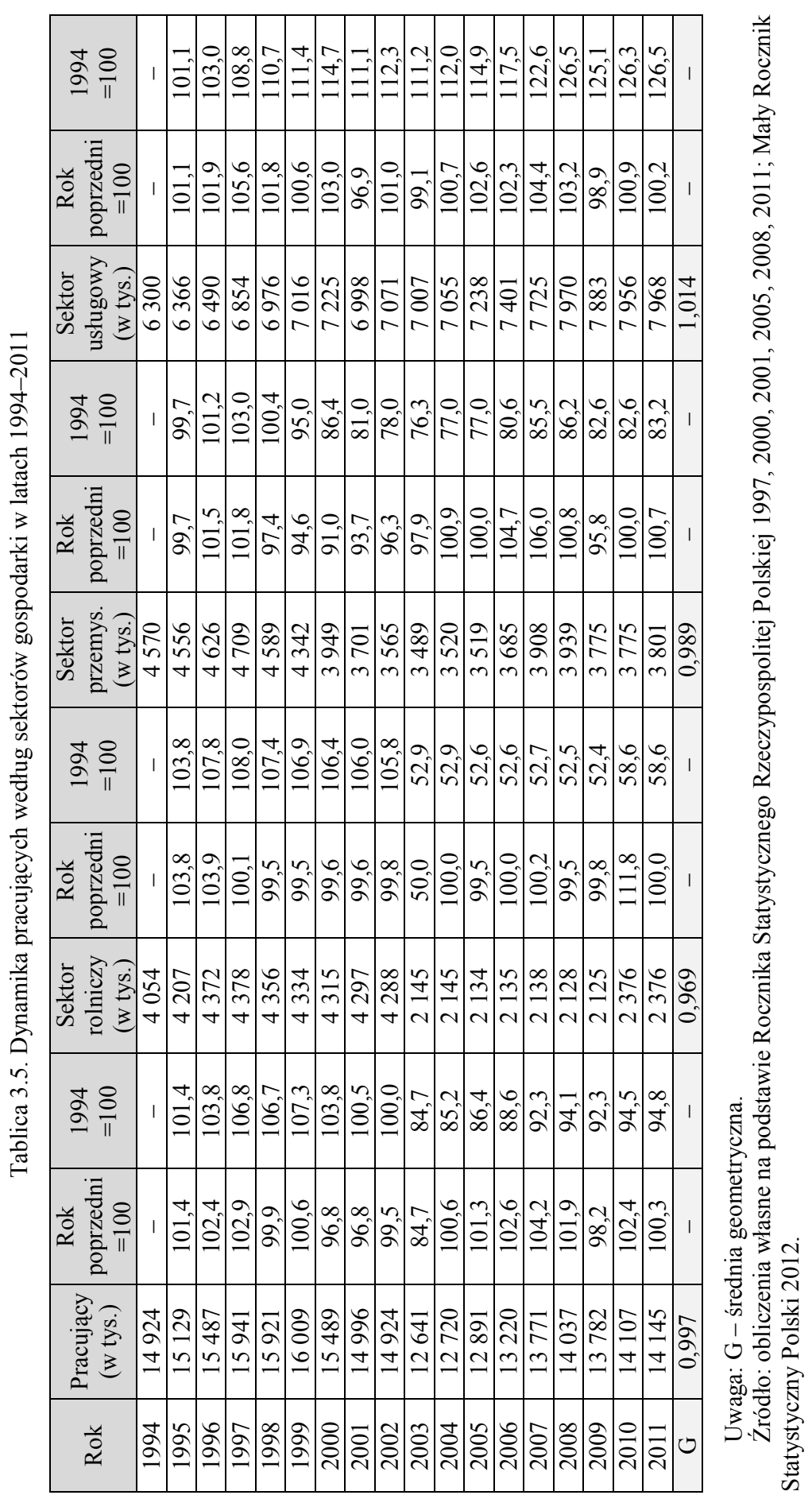




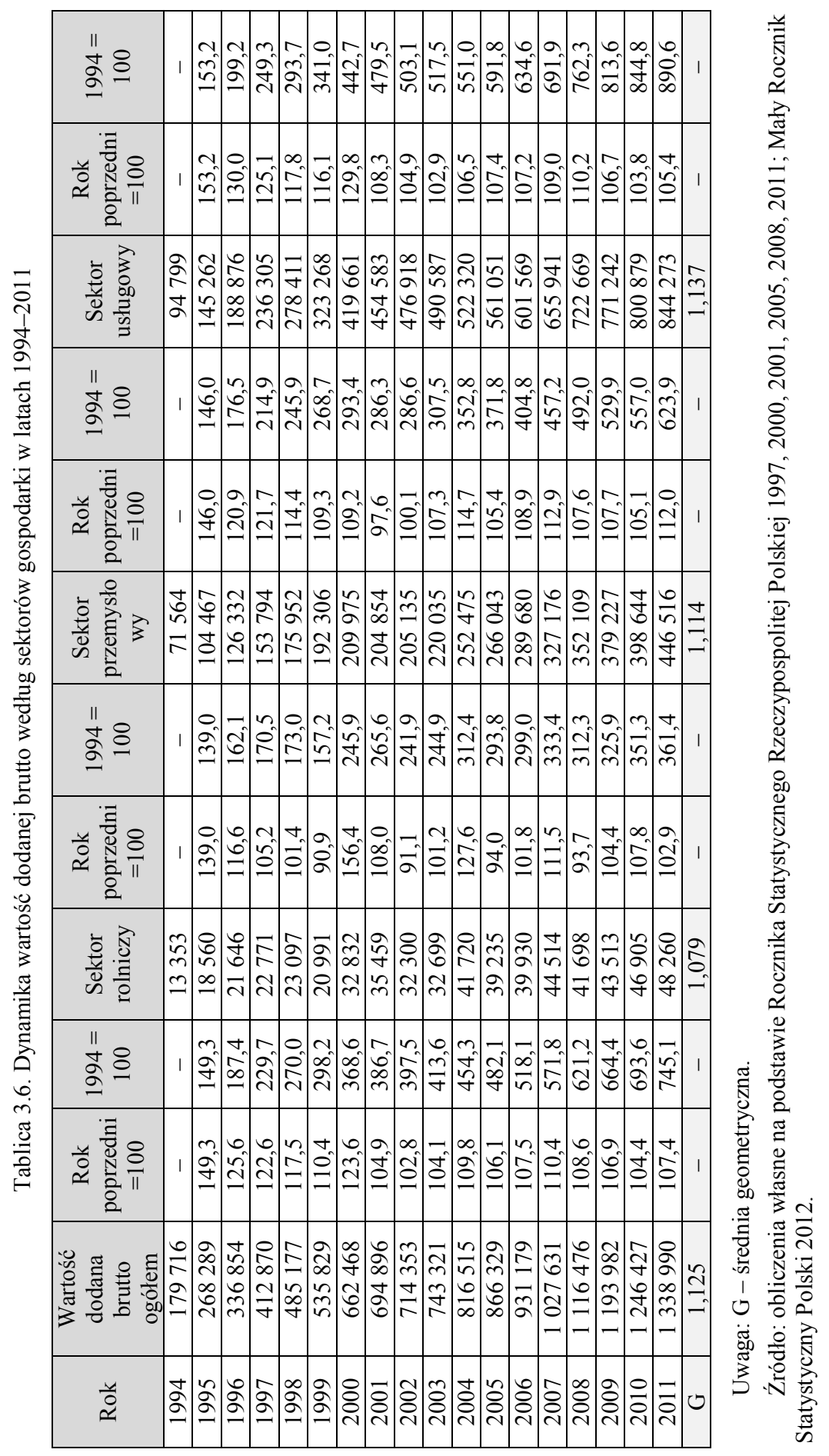


W latach 1994-2011 średnie roczne tempo wzrostu wartości dodanej brutto ogółem wynosiło $12,5 \%$, w sektorze rolnym $7,9 \%$, w przemyśle $11,4 \%$, natomiast w usługach 13,7\%. W latach 2000-2006 wartość dodana sektora usług wzrosła o $42,1 \%$, w całej gospodarce wzrost ten osiagnął 40,7\%. W roku 2005 w stosunku do roku 2000 nastąpił wyraźny wzrost wartości dodanej brutto sektora usług o 33,76\%. W roku 2006 udział wartości dodanej brutto wygenerowanej przez przedsiębiorstwa usługowe wyniósł $64,6 \%$. W porównaniu z rokiem 2005 wzrost wartości dodanej brutto wyniósł 7,22\%. Porównując wartość dodaną w całej gospodarce $\mathrm{z}$ wartością dodaną sektora usług w roku 2007 w porównaniu z rokiem 2000, obserwujemy wyższy wzrost omawianego wskaźnika w sektorze usług 57,35\% wobec 54,31\% dla całej gospodarki. W roku 2009 sektor usług wytworzył $64,59 \%$ ogółu wartości dodanej brutto całej gospodarki. W roku następnym sektor usług wytworzył 64,25\% wartości dodanej brutto całej gospodarki, a w porównaniu do roku 2000 zanotował wzrost o ponad $90 \%$.

Zwróćmy teraz uwagę na dynamikę podmiotów gospodarczych zarejestrowanych w rejestrze REGON w latach 2005-2011 (tab. 3.7).

Tablica 3.7. Dynamika podmiotów gospodarczych zarejestrowanych w rejestrze REGON w latach 2005-2011

\begin{tabular}{|c|c|c|c|c|c|c|}
\hline Rok & $\begin{array}{c}\text { Podmioty } \\
\text { ogółem }\end{array}$ & $\begin{array}{c}\text { Indeksy } \\
\text { łańcuchowe }\end{array}$ & $\begin{array}{c}2005 \\
=100\end{array}$ & $\begin{array}{c}\text { Liczba podmio- } \\
\text { tów w usługach }\end{array}$ & $\begin{array}{c}\text { Indeksy } \\
\text { lańcuchowe }\end{array}$ & $\begin{array}{c}2005 \\
=100\end{array}$ \\
\hline 2005 & 3615621 & - & 100,00 & 2776459 & - & 100,00 \\
\hline 2006 & 3636039 & 100,56 & 100,56 & 2795740 & 100,69 & 100,69 \\
\hline 2007 & 3685608 & 101,36 & 101,93 & 2817216 & 100,77 & 101,46 \\
\hline 2008 & 3757093 & 101,94 & 103,91 & 2857304 & 101,42 & 102,91 \\
\hline 2009 & 3742673 & 99,62 & 103,51 & 2849526 & 99,72 & 102,63 \\
\hline 2010 & 3909802 & 104,46 & 108,12 & 2970470 & 104,24 & 106,98 \\
\hline 2011 & 3869897 & 98,98 & 107,03 & 2940055 & 98,97 & 105,89 \\
\hline
\end{tabular}

Źródło: obliczenia własne na podstawie: Zmiany strukturalne grup podmiotów gospodarki narodowej w 2006; Zmiany strukturalne grup podmiotów gospodarki narodowej w 2007; Zmiany strukturalne grup podmiotów gospodarki narodowej w 2008; Zmiany strukturalne grup podmiotów gospodarki narodowej w 2010, Bank Danych Lokalnych.

Wśród ponad 3,6 mln podmiotów gospodarczych zarejestrowanych w rejestrze REGON w 2005 r. około 2,8 mln podmiotów to przedsiębiorstwa usługowe, co stanowiło prawie $77 \%$. W roku 2006 w porównaniu z 2005 r. liczba podmiotów usługowych wzrosła o prawie 7\%. W 2007 r. podmioty usługowe stanowiły $76,43 \%$ ogółu podmiotów gospodarczych, w analizowanym roku liczba podmiotów usługowych wzrosła o $0,77 \%$. Rok 2008 także charakteryzował się tendencją wzrostową o 1,42\%. W 2009 r. przedsiębiorstwa prowadzące działalności usługowe stanowiły $76,13 \%$ ogółu zarejestrowanych podmiotów, wyka- 
zały jednak niewielki spadek w stosunku do roku 2008 o około $0,3 \%$. W roku 2010 liczba podmiotów gospodarczych zarejestrowanych w rejestrze REGON wynosiła ponad 3,9 mln, przy czym 2,9 mln stanowiły przedsiębiorstwa usługowe. W porównaniu z rokiem 2005 nastapił wzrost podmiotów usługowych o prawie 7\%. W roku 2011 obserwujemy niewielki spadek zarówno podmiotów gospodarczych ogółem, jak i w sektorze usług.

Na podstawie przeprowadzonych analiz empirycznych można stwierdzić, że w badanym okresie w gospodarce Polski wystapiły wyraźne zmiany w strukturze sektorowej. W gospodarce polskiej zmniejszyło się znaczenie sektora rolnego w procesie wytwarzania wartości dodanej brutto oraz w poziomie zatrudnienia, podobne zmiany zostały zaobserwowane w sektorze przemysłowym.

Dokonując dalszych analiz strukturalnych w sektorze usług, należy uwzględnić fakt, że na sektor usług składa się wiele różnych rodzajów usług, które charakteryzują się zróżnicowanym udziałem w tworzeniu wartości dodanej brutto i różnym poziomem zatrudnienia. Sektor usług jest bardzo wrażliwy na pojawianie się nowych produktów i technologii, które wpływają na zmianę struktury sektora poprzez pojawianie się nowych rodzajów usług. Po analizach trójsektorowych, polegających na porównaniach odpowiednich wskaźników, przejdźmy teraz do analizy wewnętrznej sektora usług.

\subsection{Struktura wewnętrzna sektora usług}

Zgodnie z koncepcją trzech sektorów analiza danych wskazuje na zmniejszenie roli sektora pierwszego i drugiego oraz wzrost znaczenia sektora usług. W celu poznania struktury wewnętrznej sektora usług przeprowadzono pogłębioną analizę ze zwróceniem uwagi na poszczególne sekcje należące do badanego sektora. Strukturę tworzenia wartości dodanej brutto w sektorze usług przedstawia aneks 1.W latach 2005-2010 działalnością dominującą pod względem wartości dodanej była działalność handlowa, jej udział w 2010 r. przekroczył $30 \%$ wartości dodanej w sektorze usług. Sektor handlu i napraw jest jedną z najważniejszych sekcji pod względem udziału w wytworzonej wartości dodanej. Na uwagę zasługuje także działalność w zakresie transportu i gospodarki magazynowej z udziałem w 2010 r. 9,36\% oraz działalność związana z obsługą nieruchomości stanowiącą w 2010 r. 8,79\% wartości dodanej w sektorze usług. Łączny udział tych trzech sekcji w tworzeniu wartości dodanej brutto sektora usług wyniósł ponad 48\%. Najmniejszy udział, nie przekraczający 1\%, stanowią gospodarstwa domowe zatrudniające pracowników oraz wytwarzające produkty na własne potrzeby. Małe znaczenie w tworzeniu wartości dodanej brutto ma także działalność związana z kultura, rozrywką i rekreacją 1,31\% w 2010 r. oraz 
działalność związana z zakwaterowaniem i gastronomią stanowiąca w $2010 \mathrm{r}$. $1,93 \%$.

Liczba pracujących kształtowała się różnie w zależności od rodzaju prowadzonej przez przedsiębiorstwa działalności usługowej (aneks 2). W roku 2010 w porównaniu $\mathrm{z}$ latami wcześniejszymi w większości sekcji nastąpił wzrost liczby pracujących. W latach 2005-2010 największym udziałem pracujących w sektorze usług charakteryzował się handel i naprawy. W roku 2010 udział pracujących w tej sekcji wynosił $27,51 \%$ ogółu zatrudnionych w sektorze usług . Zarówno pod względem udziału w wartości dodanej brutto, jak i liczbie pracujących sekcja handel i naprawy jest największą sekcją sektora usług w Polsce. Na drugim miejscu znajduje się edukacja, gdzie udział pracujących w ostatnich latach pozostaje na niezmiennym poziomie około $13 \%$, oraz administracja publiczna, obrona narodowa i obowiązkowe zabezpieczenia społeczne stanowiące $12,19 \%$ ogółu zatrudnionych w sektorze usług w 2010 r. W roku 2011 największa liczba osób także pracowała w sekcji handel i naprawy i wynosiła $27,4 \%$ ogółu pracujących $\mathrm{w}$ podmiotach usługowych. W edukacji pracowało $13,5 \%$, a w administracji publicznej i obronie narodowej $12 \%$. Badanie struktury pracujących w sektorze usług pokazało, które usługi przeważają w przemianach strukturalnych, a tym samym wskazało na kierunki rozwoju i konkurencyjność wybranych sekcji. Poza tym należy stwierdzić, że wzrasta zapotrzebowanie na pracę wymagającą wyższych kwalifikacji w nowoczesnych sektorach gospodarki. Wraz ze wzrostem zamożności społeczeństwa rośnie popyt na usługi edukacyjne, zdrowotne, turystyczne i finansowe.

Obserwowany rozwój sektora usług znajduje swoje odzwierciedlenie także w danych charakteryzujących działalność podmiotów usługowych (tab. 3.10). Wśród podmiotów gospodarczych zarejestrowanych w rejestrze REGON w sektorze usług największy udział w 2011 r. miały przedsiębiorstwa handlowe i o charakterze naprawczym - 36\% Podobnie było w 2010 r., przedsiębiorstwa handlowe i o charakterze naprawczym stanowiły $37 \%$ ogólnej liczby zarejestrowanych podmiotów usługowych. Niewielki spadek w porównaniu z rokiem 2009 był konsekwencją spowolnienia gospodarczego. Znacznym udziałem charakteryzowały się także podmioty zajmujące się działalnością profesjonalna, naukową i techniczną; stanowiły one $11 \%$, oraz przedsiębiorstwa zajmujące się transportem i gospodarką magazynową - niecałe $9 \%$. W literaturze zwraca się uwagę na niskie nakłady na działalność badawczą i rozwojową. 


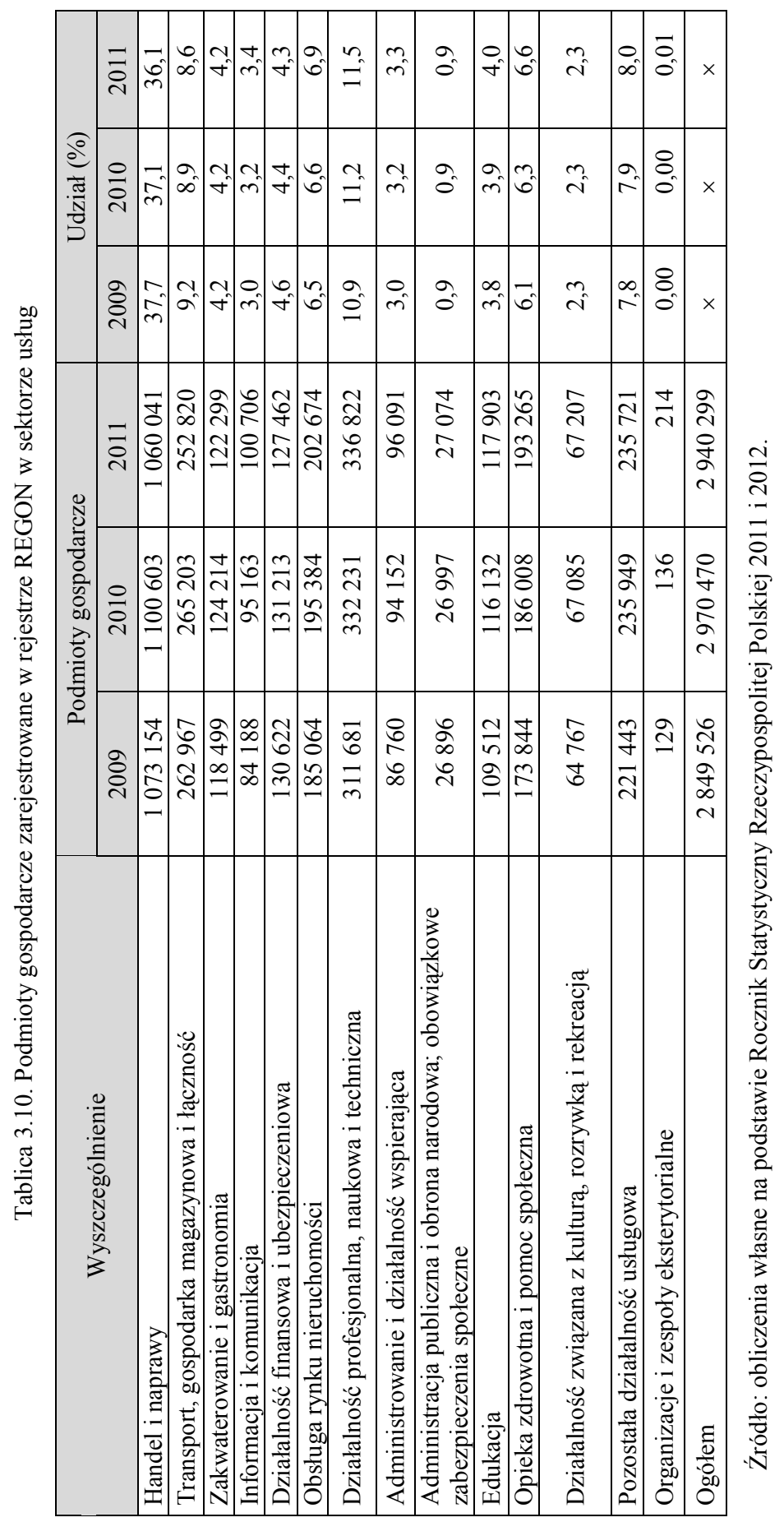


Kruszka (2006) podkreśla, że przedsiębiorstwa usługowe dobrze sobie radzą z dokonywaniem innowacji marketingowych, za którymi nie stoi zmiana technologii, wymagająca wysokich wydatków na badania i rozwój. Wśród przedsiębiorstw usługowych dominują małe podmioty, które nawet po wygospodarowaniu pewnych kwot na $\mathrm{B}+\mathrm{R}$ nie są $\mathrm{w}$ stanie przekroczyć progu nakładów, co pozwoliłoby na odczuwalne efekty. Poza tym firmy usługowe wykazują duże zainteresowanie czerpaniem wiedzy z zewnattrz opartej, np. na gotowych oprogramowaniach. Nie należy jednak wyciagać wniosku o braku zainteresowania innowacyjnością.

Dotychczasowa analiza wartości dodanej brutto i poziomu zatrudnienia zwróciła uwagę na występowanie znacznego zróżnicowania poszczególnych grup usług. Analiza danych zawartych w tab. 3.11 wskazuje na przewagę usług rynkowych w tworzeniu wartości dodanej brutto nad usługami nierynkowymi. W 2011 r. wartość dodana brutto w sektorze wynosiła 838,5 mld zł, w tym około $76,8 \% \mathrm{w}$ sektorze usług rynkowych, a $23,3 \% \mathrm{w}$ sektorze usług nierynkowych.

Tablica 3.11. Wartość dodana brutto w sektorze usług z podziałem na usługi rynkowe i nierynkowe

\begin{tabular}{|l|c|c|c|c|c|c|c|c|}
\hline \multicolumn{1}{|c|}{ Wyszczególnienie } & 2005 & 2006 & 2007 & 2008 & 2009 & 2010 & \multicolumn{2}{c|}{$\begin{array}{c}\text { Struktura } \\
\text { w }\end{array}$} \\
\cline { 5 - 10 } & & & & & & & 2005 & 2010 \\
\hline Sektor usług ogółem & 559,4 & 599,4 & 658,0 & 720,9 & 760,4 & 800,9 & 64,6 & 64,3 \\
\hline Usługi rynkowe, w tym: & 407,0 & 438,3 & 484,2 & 528,3 & 553,1 & 586,9 & 47,0 & 47,1 \\
\hline $\begin{array}{l}\text { handel, naprawa pojazdów } \\
\text { samochodowych }\end{array}$ & 163,0 & 175,0 & 188,7 & 204,2 & 224,6 & 242,5 & 18,8 & 19,5 \\
\hline $\begin{array}{l}\text { transport i gospodarka } \\
\text { magazynowa }\end{array}$ & 47,8 & 53,0 & 58,1 & 61,3 & 67,1 & 74,4 & 5,5 & 6,0 \\
\hline informacja i komunikacja & 37,3 & 38,3 & 41,2 & 46,1 & 48,6 & 46,0 & 4,3 & 3,7 \\
\hline $\begin{array}{l}\text { działalność finansowa } \\
\text { i ubezpieczeniowa }\end{array}$ & 38,2 & 42,6 & 54,8 & 59,2 & 46,9 & 53,7 & 4,4 & 4,3 \\
\hline obsługa rynku nieruchomości & 55,7 & 59,2 & 62,4 & 67,7 & 67,3 & 69,8 & 6,4 & 5,6 \\
\hline $\begin{array}{l}\text { działalność profesjonalna, } \\
\text { naukowa i techniczna }\end{array}$ & 43,5 & 46,8 & 52,1 & 59,1 & 64,3 & 63,7 & 5,0 & 5,1 \\
\hline Usługi nierynkowe, w tym: & 152,4 & 161,1 & 173,8 & 192,6 & 207,3 & 214,0 & 17,6 & 17,2 \\
\hline $\begin{array}{l}\text { administracja publiczna } \\
\text { i obrona narodowa }\end{array}$ & 46,5 & 48,9 & 52,9 & 59,6 & 65,2 & 66,5 & 5,4 & 5,3 \\
\hline edukacja & 44,6 & 46,5 & 49,8 & 53,5 & 58,0 & 61,0 & 5,1 & 4,9 \\
\hline $\begin{array}{l}\text { opieka zdrowotna i pomoc spo- } \\
\text { łeczna }\end{array}$ & 30,8 & 34,1 & 37,5 & 42,0 & 44,8 & 47,8 & 3,6 & 3,8 \\
\hline
\end{tabular}

Źródło: obliczenia własne na podstawie Banku Danych Lokalnych. 
Wartość dodana wytwarzana przez usługi rynkowe w roku 2010 w porównaniu z rokiem 2005 zwiększyła się o 22,8\% (por. tab. 3.12), natomiast w usługach nierynkowych o $9,9 \%$. Wśród usług rynkowych najwyższy wzrost o $29,7 \%$ miał miejsce w działalności profesjonalnej, naukowej i technicznej. Prawie 25\% wzrost zaobserwowano także w handlu i naprawie pojazdów samochodowych. Wśród usług nierynkowych najwyższy wzrost wartości dodanej brutto miał miejsce w działalności związanej z opieką zdrowotną i pomocą społeczną.

Tablica 3.12. Dynamika wartości dodanej brutto w sektorze usług z podziałem na usługi rynkowe i nierynkowe

\begin{tabular}{|c|c|c|c|c|c|c|}
\hline Wyszczególnienie & 2006 & 2007 & 2008 & 2009 & 2010 & $2010 / 2005$ \\
\hline Sektor usług ogółem & 104,6 & 105,9 & 105,2 & 100,4 & 102,0 & 119,2 \\
\hline Usługi rynkowe, w tym: & 105,3 & 107,2 & 106 & 99,7 & 102,9 & 122,8 \\
\hline $\begin{array}{l}\text { handel, naprawa pojazdów } \\
\text { samochodowych }\end{array}$ & 104,7 & 104,7 & 106,4 & 104,3 & 102,6 & 124,8 \\
\hline transport i gospodarka magazynowa & 109,9 & 104,2 & 98,5 & 95,6 & 106,5 & 114,8 \\
\hline informacja i komunikacja & 104,5 & 106,5 & 109,5 & 103,4 & 98,1 & 123,6 \\
\hline $\begin{array}{l}\text { działalność finansowa } \\
\text { i ubezpieczeniowa }\end{array}$ & 105,2 & 130,3 & 115,4 & 72,5 & 103,2 & 118,4 \\
\hline obsługa rynku nieruchomości & 103,6 & 97,6 & 99,0 & 103,2 & 105,7 & 109,2 \\
\hline $\begin{array}{l}\text { działalność profesjonalna, naukowa } \\
\text { i techniczna }\end{array}$ & 104,7 & 109,5 & 108,2 & 105,0 & 99,6 & 129,7 \\
\hline Usługi nierynkowe, w tym: & 102,6 & 102,3 & 102,8 & 102,3 & 99,6 & 109,9 \\
\hline $\begin{array}{l}\text { administracja publiczna i obrona } \\
\text { narodowa, obowiązkowe } \\
\text { zabezpieczenia społeczne }\end{array}$ & 101,8 & 105,7 & 102,3 & 103,8 & 98,9 & 113,0 \\
\hline edukacja & 100,4 & 101,1 & 100,6 & 101,2 & 98,8 & 102,1 \\
\hline opieka zdrowotna i pomoc społeczna & 104,6 & 100,7 & 102,6 & 104,7 & 103,6 & 117,4 \\
\hline
\end{tabular}

Źródło: obliczenia własne na podstawie Banku Danych Lokalnych.

W analizowanym okresie nastąpiły także zmiany w poziomie zatrudnienia. W 2010 r. w usługach rynkowych znalazło zatrudnienie 37,5 \% ogółu zatrudnionych w gospodarce, zaś w usługach nierynkowych $264 \%$ (por. tab. 3.13). Wśród usług rynkowych najwyższym udziałem zatrudnienia charakteryzował się handel i naprawa pojazdów, było to $16,4 \%$, a usługach nierynkowych edukacja, która stanowiła $10,6 \%$. 
Tablica 3.13. Przeciętne zatrudnienie (tys. osób) w sektorze usług z podziałem na usługi rynkowe i nierynkowe

\begin{tabular}{|l|r|r|r|r|r|r|r|r|}
\hline \multicolumn{1}{|c|}{ Wyszczególnienie } & 2005 & 2006 & 2007 & 2008 & 2009 & 2010 & \multicolumn{2}{c|}{$\begin{array}{c}\text { Struktura } \\
\text { (w } \%\end{array}$} \\
\hline & & & & & & & 2005 & 2010 \\
\hline Sektor usług ogółem & 5496,4 & 5592,9 & 5819,0 & 6139,2 & 6187,8 & 6230,4 & 62,55 & 63,94 \\
\hline Usługi rynkowe, w tym: & 3101,2 & 3187,3 & 3378,1 & 3663,1 & 3635,9 & 3658,1 & 35,29 & 37,54 \\
\hline $\begin{array}{l}\text { handel, naprawa pojazdów } \\
\text { samochodowych }\end{array}$ & 1379,9 & 1416,2 & 1508,9 & 1633,5 & 1611,5 & 1598,7 & 15,70 & 16,41 \\
\hline $\begin{array}{l}\text { transport i gospodarka } \\
\text { magazynowa }\end{array}$ & 507,4 & 524,1 & 550,8 & 602,4 & 581,8 & 582,5 & 5,77 & 5,98 \\
\hline informacja i komunikacja & 155,5 & 155,7 & 166,1 & 189,6 & 195,7 & 195,3 & 1,77 & 2,00 \\
\hline $\begin{array}{l}\text { działalność finansowa } \\
\text { i ubezpieczeniowa }\end{array}$ & 244,0 & 250,5 & 260,7 & 282,7 & 278,9 & 281,7 & 2,78 & 2,89 \\
\hline obsługa rynku nieruchomości & 133,6 & 133,4 & 137,5 & 138,7 & 140,0 & 142,0 & 1,52 & 1,46 \\
\hline $\begin{array}{l}\text { działalność profesjonalna, } \\
\text { naukowa i techniczna }\end{array}$ & 270,5 & 277,7 & 294,2 & 313,9 & 326,3 & 328,4 & 3,08 & 3,37 \\
\hline Usługi nierynkowe, w tym: & 2395,2 & 2405,6 & 2440,9 & 2476,1 & 2551,9 & 2572,3 & 27,26 & 26,40 \\
\hline $\begin{array}{l}\text { administracja publiczna i } \\
\text { obrona narodowa, }\end{array}$ & 551,8 & 559,9 & 574,4 & 586,4 & 629,5 & 642,8 & 6,28 & 6,60 \\
\hline edukacja & 1018,2 & 1017,9 & 1020,9 & 1022,2 & 1039,0 & 1035,9 & 11,59 & 10,63 \\
\hline $\begin{array}{l}\text { opieka zdrowotna i pomoc } \\
\text { społeczna }\end{array}$ & 621,7 & 623,8 & 632,2 & 641,4 & 656,5 & 667,8 & 7,08 & 6,85 \\
\hline
\end{tabular}

Źródło: obliczenia własne na podstawie Banku Danych Lokalnych.

We wszystkich sekcjach nastapił wzrost zatrudnienia (por. tab. 3.14): w usługach rynkowych o 18\%, a w usługach nierynkowych o 7,4\%. Wśród usług rynkowych najwyższy, ponad $25 \%$ wzrost zatrudnienia wystapił w sekcji informacja i komunikacja, natomiast $\mathrm{w}$ usługach nierynkowych najwyższy wzrost, o ponad $16 \%$, zaobserwowano w administracji publicznej i obronie narodowej.

W 2011 r. podobnie jak w latach wcześniejszych w strukturze podmiotowej sektora usług dominowały przedsiębiorstwa należące do sektora prywatnego. Głównie były to przedsiębiorstwa z sekcji handel; naprawa pojazdów samochodowych (ponad 1,1 mln przedsiębiorstw), działalność profesjonalna, naukowa i techniczna (ponad 300 tys.) oraz transport i gospodarka magazynowa (ponad 250 tys.). W roku $2011 \mathrm{w}$ porównaniu z rokiem $2010 \mathrm{w}$ sektorze publicznym, prawie we wszystkich sekcjach sektora usług, obserwujemy spadek liczby podmiotów gospodarczych, niewiele lepsza sytuacja miała miejsce w sektorze prywatnym. Sytuacja taka może świadczyć o spowolnieniu gospodarczym, którego sektor usług także doświadcza. 
Tablica 3.14. Dynamika przeciętnego zatrudnienia (tys. osób) w sektorze usług z podziałem na usługi rynkowe i nierynkowe

\begin{tabular}{|l|c|c|c|c|c|c|}
\hline \multicolumn{1}{|c|}{ Wyszczególnienie } & 2006 & 2007 & 2008 & 2009 & 2010 & $2010 / 2005$ \\
\hline Sektor usług ogółem & 101,8 & 104 & 105,5 & 100,8 & 100,7 & 113,4 \\
\hline Usługi rynkowe, w tym: & 102,8 & 106 & 108,4 & 99,3 & 100,6 & 118,0 \\
\hline $\begin{array}{l}\text { handel, naprawa pojazdów } \\
\text { samochodowych }\end{array}$ & 102,6 & 106,5 & 108,3 & 98,7 & 99,2 & 115,9 \\
\hline $\begin{array}{l}\text { transport i gospodarka } \\
\text { magazynowa }\end{array}$ & 103,3 & 105,1 & 109,4 & 96,6 & 100,1 & 114,8 \\
\hline informacja i komunikacja & 100,1 & 106,7 & 114,1 & 103,2 & 99,8 & 125,6 \\
\hline $\begin{array}{l}\text { działalność finansowa } \\
\text { i ubezpieczeniowa }\end{array}$ & 102,7 & 104,1 & 108,4 & 98,7 & 101 & 115,5 \\
\hline obsługa rynku nieruchomości & 99,9 & 103,1 & 100,9 & 100,9 & 101,4 & 106,3 \\
\hline $\begin{array}{l}\text { działalność profesjonalna, na- } \\
\text { ukowa i techniczna }\end{array}$ & 102,7 & 105,9 & 106,7 & 104 & 100,6 & 121,4 \\
\hline Usługi nierynkowe, w tym: & 100,4 & 101,5 & 101,4 & 103,1 & 100,8 & 107,4 \\
\hline $\begin{array}{l}\text { administracja publiczna } \\
\text { i obrona narodowa, obowiąz- } \\
\text { kowe zabezpieczenie społeczne }\end{array}$ & 101,5 & 102,6 & 102,1 & 107,3 & 102,1 & 116,5 \\
\hline edukacja & 100,0 & 100,3 & 100,1 & 101,6 & 99,7 & 101,7 \\
\hline $\begin{array}{l}\text { opieka zdrowotna i pomoc } \\
\text { społeczna }\end{array}$ & 100,3 & 101,3 & 101,5 & 102,4 & 101,7 & 107,4 \\
\hline
\end{tabular}

Źródło: obliczenia własne na podstawie Banku Danych Lokalnych.

Przeprowadzone dotychczas analizy pozwalają na stwierdzenie, że wyznacznikami poziomu rozwoju sektora usług są nie tylko jego wysokie udziały w strukturach trójsektorowych, ale także wewnętrzne zmiany obserwowane w samym sektorze.

O rozwoju społeczno-gospodarczym kraju i jego jednostek terytorialnych świadczy wiele wskaźników o charakterze ekonomicznym i społecznym. Zwykle w badaniach opieramy się na liczbie pracujących oraz wartości dodanej brutto, jednak w celu pogłębionej analizy sektora usług słuszne wydało się zwrócenie uwagi na inne wskaźniki (np. nakłady inwestycyjne, nakłady na działalność badawczo-rozwojową), mające także wpływ na rozwój sektora usług. Do tego celu wykorzystano metodę analizy czynnikowej. 


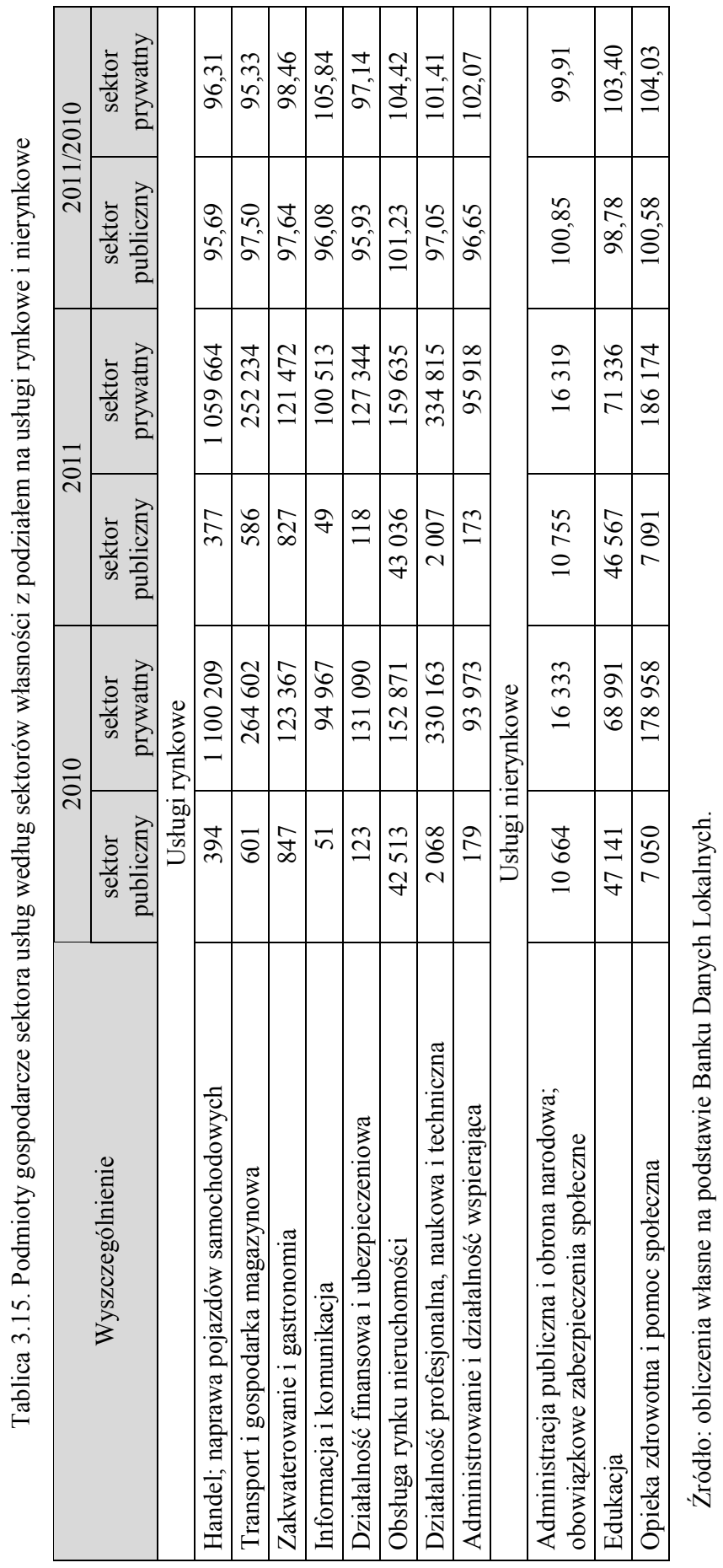




\subsection{Charakterystyka sektora usług oparta na analizie czynnikowej}

W celu monitorowania poziomu rozwoju sektora usług dokonuje się ciagłego porównywania odpowiednich mierników umożliwiających ocenę i podjęcie odpowiednich działań, które zapewniają odpowiedni rozwój. Ze względu na rosnącą rolę sektora usług potrzeba badań nad usługami stała się rzeczą ważną i oczywistą.

Ocenę rozwoju rynku usług zwykle przeprowadza się na podstawie analizy liczby pracujących w tym sektorze, wartości dodanej brutto oraz liczby podmiotów gospodarczych zarejestrowanych w rejestrze REGON w sektorze usług. Podejście takie niejednokrotnie poddawane jest krytyce, ponieważ nie w pełni odzwierciedla poziom rozwoju usług. W związku z tym, że rozwój sektora usług jest zjawiskiem złożonym, słuszne wydało się podjęcie próby oceny rozwoju sektora III opartego na szerszym zbiorze zmiennych. W celu zredukowania dużej liczby zmiennych do kilku wzajemnie nieskorelowanych zastosowano metodę analizy czynnikowej. Dokonano analizy wybranych zmiennych dla 16 województw. Wejściowy zbiór zmiennych przedstawiał się następująco:

$\mathrm{X}_{1}-$ ludność $\mathrm{w}$ tys.,

$\mathrm{X}_{2}$ - pracujący w sektorze usług w tys.,

$\mathrm{X}_{3}$ - nakłady inwestycyjne w sektorze usług w mln,

$\mathrm{X}_{4}$ - bezrobotni ogółem w tys. w $2010 \mathrm{r}$,

$\mathrm{X}_{5}$ - nakłady na działalność badawczą i rozwojową ogółem w mln zł,

$\mathrm{X}_{6}$ - wartość dodana brutto w usługach $\mathrm{w}$ mln $\mathrm{z}$,

$\mathrm{X}_{7}$ - podmioty gospodarcze zarejestrowane $\mathrm{w}$ rejestrze REGON w sektorze usług,

$\mathrm{X}_{8}$ - przeciętne miesięczne wynagrodzenie brutto $\mathrm{w}$ sektorze przedsiębiorstw,

$\mathrm{X}_{9}$ - przeciętne miesięczne wydatki na 1 osobę w gospodarstwach domowych,

$\mathrm{X}_{10}$ - wskaźnik liczby ludności,

$\mathrm{X}_{11}$ - wskaźnik liczby pracujących w sektorze usług

$\mathrm{X}_{12}$ - wskaźnik nakładów inwestycyjnych w sektorze usług,

$\mathrm{X}_{13}$ - wskaźnik liczby bezrobotnych,

$\mathrm{X}_{14}$ - wskaźnik nakładów na działalność badawczą i rozwojową,

$\mathrm{X}_{15}$-wskaźnik wartości dodanej usług,

$\mathrm{X}_{16}$-wskaźnik liczby podmiotów w sektorze usług,

$\mathrm{X}_{17}$-wskaźnik przeciętnego wynagrodzenia $\mathrm{w}$ sektorze przedsiębiorstw,

$\mathrm{X}_{18}$-wskaźnik przeciętnych miesięcznych wydatków na 1 osobę.

Istota analizy polegała na znalezieniu niewielkiej liczby nowych zmiennych (czynników), które wystarczą do opisu poziomu rozwoju sektora usług, zacho- 
wają stosunkowo dużą część informacji tkwiących w zmiennych pierwotnych, poza tym będą od siebie niezależne oraz ujawnią niewidoczną inaczej strukturę danych. W analizie czynnikowej wyodrębniamy każdy kolejny czynnik, następnie zadajemy pytanie, ile czynników pozostawić. W tym celu możemy posłużyć się kilkoma wytycznymi, które się powszechnie stosuje i które w praktyce dają dobre rezultaty. Są to kryterium Kaisera i test osypiska. Opierając się na kryterium Kaisera, możemy zostawić tylko czynniki, które mają wartości własne większe niż 1, to znaczy, że jeśli czynnik nie wyjaśnia zmienności przynajmniej tyle, ile wynosi jedna zmienna oryginalna, to go odrzucamy. Test osypiska jest metodą graficzna, na wykresie przedstawiamy wartości własne z arkusza wyników i znajdujemy miejsce, od którego na prawo występuje łagodny spadek wartości własnych.

Do analizy uwzględniono informacje z roku 2005 i 2010. W celu wykorzystania informacji na temat zmian wskaźników policzono zestaw wskaźników określający zmiany. Wskaźniki te wyznaczono jako różnice między wskaźnikami w roku 2010 a odpowiadającymi im wskaźnikami z roku 2005, podzielono przez średnią z tych dwóch wskaźników. Przed wykonaniem analizy czynnikowej upewniono się, że dane wprowadzone do analizy spełniają założenia pozwalające na właściwą interpretację wyodrębnionych czynników oraz dokonanie dalszych obliczeń z ich wykorzystaniem. W tym celu posłużono się testem sferyczności Bartlletta, który potwierdził istotność macierzy oraz miarą KMO określającą stopień adekwatności próby do założeń analizy czynnikowej. Otrzymana wartość KMO $(0,68)$ także dała podstawy do stosowania analizy czynnikowej. Ładunki czynnikowe wyznaczono, wykorzystując metodę składowych głównych. Na uwagę zasługuje fakt, że rozwiązanie uzyskane jako pierwsze charakteryzuje się wysokimi wartościami ładunków stojących przy pierwszym czynniku dla wszystkich lub większości zmiennych, co wpływa na trudności interpretacyjne. Problem ten można ograniczyć, stosując rotacje, której celem jest zminimalizowanie jednego $\mathrm{z}$ ładunków, $\mathrm{w}$ taki sposób, by zmienna rzeczywista była kształtowana tylko przez jeden czynnik. Jednym z typów rotacji, który wykorzystano w badaniu, jest rotacja Varimax.

Wykonano analizę czynnikową na 18 zmiennych i wyłoniono jeden czynnik metodą składowych głównych, policzoną na macierzy korelacji. Wypisano te ładunki czynnikowe, których wartość bezwzględna jest większa od 0,4, dodatkowo pogrubiono te, których wartość jest większa od 0,7.

Otrzymane ładunki czynnikowe są współczynnikami korelacji pomiędzy zmiennymi wejściowymi i czynnikami. Następnie przeprowadzono analizę czynnikową, która pozwoliła wyłonić dwa czynniki wyjaśniające $56 \%$ wariancji (tab. 3.17). 
Tablica 3.16. Macierz nierotowanych ładunków analizy czynnikowej

\begin{tabular}{|l|r|r|}
\hline \multicolumn{1}{|c|}{ Wyszczególnienie } & $\begin{array}{c}\text { Zmienność } \\
\text { wspólna } \\
\left(\mathrm{h}^{2}\right) \mathrm{w} \%\end{array}$ & Czynnik 1 \\
\hline Procent wyjaśnionej wariancji & & 40 \\
\hline Wartości własne & 6 & 7,20 \\
\hline Ludność (2010) & 93 & $\mathbf{0 , 9 6}$ \\
\hline Pracujący w sektorze usług (2010) & 15 & \\
\hline Nakłady inwestycyjne w sektorze usług (2010) & 32 & $-0,57$ \\
\hline Bezrobotni ogółem (2010) & 75 & $\mathbf{0 , 8 7}$ \\
\hline Nakłady na działalność badawczą i rozwojową (2010) & 84 & $\mathbf{0 , 9 2}$ \\
\hline Wartość dodana brutto usługi (2010) & 50 & $\mathbf{0 , 7 0}$ \\
\hline Podmioty w sektorze usług (2010) & 53 & $-\mathbf{0 , 7 3}$ \\
\hline Przeciętne wynagrodzenia w sektorze przedsiębiorstw (2010) & 48 & $-0,69$ \\
\hline Przeciętne miesięczne wydatki na 1 osobę (2010) & 44 & 0,67 \\
\hline Wskaźnik liczby ludności & 49 & 0,70 \\
\hline Wskaźnik liczby pracujących w sektorze usług & 66 & $-\mathbf{0 , 8 1}$ \\
\hline Wskaźnik nakładów inwestycyjnych w sektorze usług & 11 & \\
\hline Wskaźnik liczby bezrobotnych & 9 & \\
\hline Wskaźnik nakładów na działalność badawczą i rozwojową & 36 & 0,60 \\
\hline Wskaźnik wartości dodanej usług & 4 & \\
\hline Wskaźnik liczby podmiotów w sektorze usług & 17 & $-0,41$ \\
\hline Wskaźnik przeciętnego wynagrodzenia w sektorze przedsiębiorstw & 28 & 0,53 \\
\hline Wskaźnik przeciętnych miesięcznych wydatków na 1 osobę & & \\
\hline
\end{tabular}

Źródło: obliczenia własne.

Tablica 3.17. Macierz rotowanych metodą Rotacji Varimax ładunków analizy czynnikowej

\begin{tabular}{|l|c|c|c|}
\hline \multicolumn{1}{|c|}{ Wyszczególnienie } & $\begin{array}{c}\text { Zmienność } \\
\text { wspólna } \\
\left(\mathrm{h}^{2}\right) \mathrm{w} \%\end{array}$ & Czynnik 1 & Czynnik 2 \\
\hline \multicolumn{1}{|c|}{1} & 2 & 3 & 4 \\
\hline Procent wyjaśnionej wariancji & & 31 & 25 \\
\hline Wartości własne & 7 & 5,54 & 4,45 \\
\hline Ludność (2010) & 96 & 0,66 & $\mathbf{0 , 7 3}$ \\
\hline Pracujący w sektorze usług (2010) & 54 & & $\mathbf{0 , 7 3}$ \\
\hline Nakłady inwestycyjne w sektorze usług (2010) & 44 & $-0,66$ & \\
\hline Bezrobotni ogółem (2010) & 75 & 0,70 & 0,51 \\
\hline $\begin{array}{l}\text { Nakłady na działalność badawczą i rozwojową } \\
\text { (2010) }\end{array}$ & 90 & 0,58 & $\mathbf{0 , 7 5}$ \\
\hline Wartość dodana brutto usługi (2010) & 75 & & $\mathbf{0 , 8 3}$ \\
\hline Podmioty w sektorze usług (2010) & 72 & & $\mathbf{- 0 , 1 1}$ \\
\hline $\begin{array}{c}\text { Przeciętne wynagrodzenia w sektorze } \\
\text { przedsiębiorstw (2010) }\end{array}$ & 69 & & $\mathbf{- 0 , 0 6}$ \\
\hline $\begin{array}{c}\text { Przeciętne miesięczne wydatki na 1 osobę } \\
\text { (2010) }\end{array}$ & & & \\
\hline
\end{tabular}


Tablica 3.17 (cd.)

\begin{tabular}{|c|c|c|c|}
\hline 1 & 2 & 3 & 4 \\
\hline Wskaźnik liczby ludności & 52 & & 0,63 \\
\hline Wskaźnik liczby pracujących w sektorze usług & 89 & $\mathbf{0 , 9 4}$ & \\
\hline $\begin{array}{c}\text { Wskaźnik nakładów inwestycyjnych w sekto- } \\
\text { rze usług }\end{array}$ & 73 & $\mathbf{- 0 , 8 0}$ & \\
\hline Wskaźnik liczby bezrobotnych & 29 & & $-0,54$ \\
\hline $\begin{array}{l}\text { Wskaźnik nakładów na działalność badawczą i } \\
\text { rozwojową }\end{array}$ & 10 & & \\
\hline Wskaźnik wartości dodanej usług & 49 & 0,69 & \\
\hline Wskaźnik liczby podmiotów w sektorze usług & 6 & & \\
\hline $\begin{array}{l}\text { Wskaźnik przeciętnego wynagrodzenia w sek- } \\
\text { torze przedsiębiorstw }\end{array}$ & 72 & & $\mathbf{- 0 , 8 4}$ \\
\hline $\begin{array}{l}\text { Wskaźnik przeciętnych miesięcznych wydat- } \\
\text { ków na 1 osobę }\end{array}$ & 38 & & 0,57 \\
\hline
\end{tabular}

Źródło: obliczenia własne.

W dalszej kolejności wyszczególniono trzy czynniki, które wyjaśniają 66\% wariancji (tab. 3.18).

Tablica 3.18. Macierz rotowanych metodą Rotacji Varimax ładunków analizy czynnikowej

\begin{tabular}{|l|c|c|c|c|}
\hline \multicolumn{1}{|c|}{ Wyszczególnienie } & $\begin{array}{c}\text { Zmienność } \\
\text { wspólna } \\
\left(\mathrm{h}^{2}\right) \mathrm{w} \%\end{array}$ & $\begin{array}{c}\text { Czynnik } \\
1\end{array}$ & $\begin{array}{c}\text { Czynnik } \\
2\end{array}$ & $\begin{array}{c}\text { Czynnik } \\
3\end{array}$ \\
\hline \multicolumn{1}{|c|}{1} & 2 & 3 & 4 & 5 \\
\hline Procent wyjaśnionej wariancji & & 29 & 24 & 14 \\
\hline Wartości własne & 8 & 5,21 & 4,26 & 2,45 \\
\hline Ludność (2010) & 96 & 0,62 & $\mathbf{0 , 7 0}$ & \\
\hline Pracujący w sektorze usług (2010) & 54 & & $\mathbf{0 , 7 3}$ & \\
\hline Nakłady inwestycyjne w sektorze usług (2010) & 85 & & & $\mathbf{0 , 8 4}$ \\
\hline Bezrobotni ogółem (2010) & 82 & $\mathbf{0 , 7 7}$ & 0,47 & \\
\hline $\begin{array}{l}\text { Nakłady na działalność badawczą i rozwojową } \\
\text { (2010) }\end{array}$ & 90 & 0,59 & $\mathbf{0 , 7 2}$ & \\
\hline Wartość dodana brutto usługi (2010) & 81 & & $\mathbf{0 , 8 3}$ & \\
\hline Podmioty w sektorze usług (2010) & 80 & $\mathbf{- 0 , 8 9}$ & & \\
\hline $\begin{array}{l}\text { Przeciętne wynagrodzenia w sektorze } \\
\text { przedsiębiorstw (2010) }\end{array}$ & 81 & $\mathbf{- 0 , 9 0}$ & & \\
\hline $\begin{array}{l}\text { Przeciętne miesięczne wydatki na 1 osobę } \\
\text { (2010) }\end{array}$ & 53 & & 0,61 & \\
\hline Wskaźnik liczby ludności & 89 & $\mathbf{0 , 8 3}$ & & $-0,45$ \\
\hline Wskaźnik liczby pracujących w sektorze usług & 74 & $\mathbf{- 0 , 7 1}$ & & 0,40 \\
\hline $\begin{array}{l}\text { Wskaźnik nakładów inwestycyjnych } \\
\text { w sektorze usług }\end{array}$ & $\mathbf{0 , 1 2}$ & & 0,33 \\
\hline Wskaźnik liczby bezrobotnych & 71 & $\mathbf{0 , 0 4}$ & & 0,82 \\
\hline $\begin{array}{l}\text { Wskaźnik nakładów na działalność badawczą } \\
\text { i rozwojową }\end{array}$ & & & \\
\hline
\end{tabular}


Tablica 3.18 (cd.)

\begin{tabular}{|l|r|r|r|r|}
\hline \multicolumn{1}{|c|}{1} & 2 & 3 & 4 & 5 \\
\hline Wskaźnik wartości dodanej usług & 52 & $\mathbf{0 , 7 1}$ & & \\
\hline Wskaźnik liczby podmiotów w sektorze usług & 9 & & & \\
\hline $\begin{array}{l}\text { Wskaźnik przeciętnego wynagrodzenia } \\
\text { w sektorze przedsiębiorstw }\end{array}$ & 75 & & $\mathbf{- 0 , 8 3}$ & \\
\hline $\begin{array}{l}\text { Wskaźnik przeciętnych miesięcznych } \\
\text { wydatków na 1 osobę }\end{array}$ & 70 & 0,47 & 0,53 & 0,44 \\
\hline
\end{tabular}

Źródło: obliczenia własne.

W toku dalszych badań wyłoniono cztery czynniki, które wyjaśniają 76\% wariancji (tab. 3.19).

Tablica 3.19. Macierz rotowanych metodą Rotacji Varimax ładunków analizy czynnikowej

\begin{tabular}{|c|c|c|c|c|c|}
\hline Wyszczególnienie & $\begin{array}{c}\text { Zmienność } \\
\text { wspólna } \\
\left(\mathrm{h}^{2}\right) \text { w \% }\end{array}$ & $\begin{array}{c}\text { Czynnik } \\
1\end{array}$ & $\begin{array}{c}\text { Czynnik } \\
2\end{array}$ & $\begin{array}{c}\text { Czynnik } \\
3\end{array}$ & $\begin{array}{c}\text { Czynnik } \\
4\end{array}$ \\
\hline Procent wyjaśnionej wariancji & & 30 & 24 & 12 & 10 \\
\hline Wartości własne & & 5,43 & 4,25 & 2,07 & 1,76 \\
\hline Ludność (2010) & 8 & & & & \\
\hline Pracujący w sektorze usług (2010) & 96 & 0,64 & 0,69 & & \\
\hline Nakłady inwestycyjne w sektorze usług (2010) & 56 & & 0,74 & & \\
\hline Bezrobotni ogółem (2010) & 87 & $-0,46$ & & $\mathbf{0 , 7 0}$ & 0,40 \\
\hline $\begin{array}{l}\text { Nakłady na działalność badawczą i rozwojową } \\
(2010)\end{array}$ & 83 & $\mathbf{0 , 7 7}$ & 0,49 & & \\
\hline Wartość dodana brutto usługi (2010) & 90 & 0,60 & $\mathbf{0 , 7 3}$ & & \\
\hline Podmioty w sektorze usług (2010) & 83 & & $\mathbf{0 , 8 1}$ & & \\
\hline $\begin{array}{l}\text { Przeciętne wynagrodzenia w sektorze przed- } \\
\text { siębiorstw }(2010)\end{array}$ & 90 & $-0,87$ & & & \\
\hline $\begin{array}{l}\text { Przeciętne miesięczne wydatki na } 1 \text { osobę } \\
(2010)\end{array}$ & 91 & $-0,87$ & & & \\
\hline Wskaźnik liczby ludności & 60 & & 0,64 & & \\
\hline Wskaźnik liczby pracujących w sektorze usług & 92 & $\mathbf{0 , 8 9}$ & & & \\
\hline $\begin{array}{l}\text { Wskaźnik nakładów inwestycyjnych w sekto- } \\
\text { rze usług }\end{array}$ & 78 & $-\mathbf{0 , 7 7}$ & & & \\
\hline Wskaźnik liczby bezrobotnych & 68 & & $-0,49$ & & 0,62 \\
\hline $\begin{array}{l}\text { Wskaźnik nakładów na działalność badawczą i } \\
\text { rozwojową }\end{array}$ & 79 & & & $\mathbf{0 , 8 7}$ & \\
\hline Wskaźnik wartości dodanej usług & 69 & 0,74 & & & \\
\hline Wskaźnik liczby podmiotów w sektorze usług & 73 & & & & $-0,84$ \\
\hline $\begin{array}{l}\text { Wskaźnik przeciętnego wynagrodzenia w sek- } \\
\text { torze przedsiębiorstw }\end{array}$ & 75 & & $-0,84$ & & \\
\hline $\begin{array}{l}\text { Wskaźnik przeciętnych miesięcznych wydat- } \\
\text { ków na } 1 \text { osobę }\end{array}$ & 73 & & 0,54 & 0,54 & \\
\hline
\end{tabular}

Źródło: obliczenia własne. 
Dalej analiza czynnikowa wyłoniła 5 czynników (tab. 3.20.), które wyjaśniają $81 \%$ wariancji.

Tablica 3.20. Macierz rotowanych metodą Rotacji Varimax ładunków analizy czynnikowej

\begin{tabular}{|c|c|c|c|c|c|c|}
\hline & Zmienność & Czynnik & Czynnik & Czynnik & Czynnik & Czynnik \\
\hline wyszczegolnienie & $\begin{array}{l}\text { wspolna } \\
\left(h^{2}\right) \text { w } \%\end{array}$ & 1 & 2 & 3 & 4 & 5 \\
\hline Procent wyjaśnionej wariancji & & 29 & 24 & 11 & 10 & 6 \\
\hline Wartości własne & & 5,28 & 4,25 & 2,06 & 1,75 & 1,15 \\
\hline Ludność (2010) & 80 & & & & & 0,89 \\
\hline Pracujący w sektorze usług (2010) & 97 & 0,61 & 0,69 & & & \\
\hline $\begin{array}{l}\text { Nakłady inwestycyjne w sektorze usług } \\
(2010)\end{array}$ & 58 & & 0,75 & & & \\
\hline Bezrobotni ogółem (2010) & 87 & $-0,44$ & & 0,71 & 0,40 & \\
\hline $\begin{array}{l}\text { Nakłady na działalność badawczą } \\
\text { i rozwojową }(2010)\end{array}$ & 84 & 0,75 & 0,49 & & & \\
\hline Wartość dodana brutto usługi (2010) & 92 & 0,57 & 0,72 & & & \\
\hline Podmioty w sektorze usług (2010) & 83 & & $\mathbf{0 , 8 0}$ & & & \\
\hline $\begin{array}{l}\text { Przeciętne wynagrodzenia w sektorze } \\
\text { przedsiębiorstw (2010) }\end{array}$ & 93 & $-0,89$ & & & & \\
\hline $\begin{array}{l}\text { Przeciętne miesięczne wydatki na } 1 \text { osobę } \\
(2010)\end{array}$ & 94 & $-0,89$ & & & & \\
\hline Wskaźnik liczby ludności & 69 & 0,41 & 0,66 & & & \\
\hline $\begin{array}{l}\text { Wskaźnik liczby pracujących w sektorze } \\
\text { usług }\end{array}$ & 92 & 0,88 & & & & \\
\hline $\begin{array}{l}\text { Wskaźnik nakładów inwestycyjnych w } \\
\text { sektorze usług }\end{array}$ & 79 & $-0,74$ & & & & \\
\hline Wskaźnik liczby bezrobotnych & 68 & & $-0,50$ & & 0,62 & \\
\hline $\begin{array}{l}\text { Wskaźnik nakładów na działalność } \\
\text { badawczą i rozwojową }\end{array}$ & 80 & & & $\mathbf{0 , 8 7}$ & & \\
\hline Wskaźnik wartości dodanej usług & 69 & 0,72 & & & & \\
\hline $\begin{array}{l}\text { Wskaźnik liczby podmiotów w sektorze } \\
\text { usług }\end{array}$ & 73 & & & & $-0,84$ & \\
\hline $\begin{array}{l}\text { Wskaźnik przeciętnego wynagrodzenia } \\
\text { w sektorze przedsiębiorstw }\end{array}$ & 76 & & $-0,84$ & & & \\
\hline $\begin{array}{l}\text { Wskaźnik przeciętnych miesięcznych } \\
\text { wydatków na } 1 \text { osobę }\end{array}$ & 76 & & 0,51 & 0,56 & & \\
\hline
\end{tabular}

Źródło: obliczenia własne.

Przeprowadzono analizę czynnikową, która pozwoliła wyłonić 6 czynników metodą składowych głównych opartą na macierzy korelacji. Przestrzeń czynników rotowano metodą rotacji Varimax i otrzymano wartości ładunków czynnikowych zawarte w tab. 3.21. 


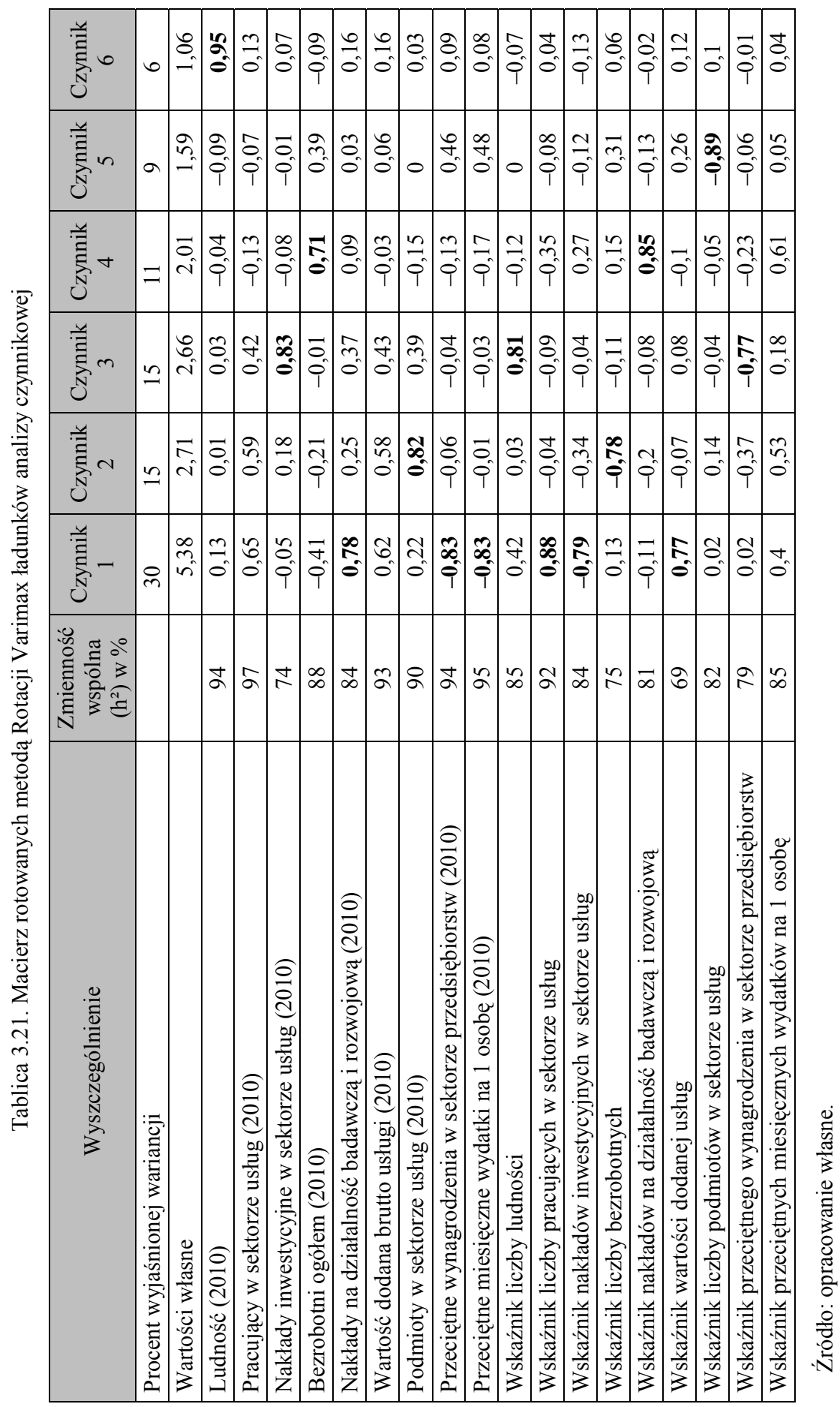


Wyszczególniono 6 czynników, których wartości własne są powyżej jedynki i które wyjaśniają $86 \%$ zmienności całego zbioru, dlatego też w końcowym rozwiązaniu można poprzestać na tych czynnikach. Wyznaczone wartości własne dały możliwość zastosowania kryterium Kaisera, według którego możliwe jest pozostawienie czynników, które należy uznać za istotne, kiedy wartość własna jest większa od jedności. Czym większa jest wartość własna czynnika, tym większy jest tzw. ładunek informacji wejściowych zmiennych zawiera dany czynnik. Uwzględniając fakt, że każda $\mathrm{z}$ wejściowych zmiennych ma wariancję równą 1 , to np. pierwszy czynnik wyjaśnia $5,38 / 18 \cdot 100=29,88 \%$ wariancji wprowadzonych zmiennych. Ładunki czynnikowe wynoszące poniżej 0,4 są traktowane jako zbyt słabo reprezentujące dany czynnik. Pomimo tego, że wszystkie zmienne mają jakieś ładunki czynnikowe w każdym z czynników, to jednak większość ładunków jest zbyt niska, aby odpowiadające im pozycje można było potraktować jako dobre wskaźniki badanego wymiaru. Dla każdego czynnika została policzona jego wartość własna, czyli wariancja zawarta w tym czynniku. Wartość własna czynnika pierwszego jest najwyższa i wynosi 5,38. Wartość własna drugiego czynnika jest już znacznie mniejsza, wynosi 2,71 wartości pozostałych czynników wynoszą odpowiednio 2,$66 ; 2,01 ; 1,59 ; 1,06$. W sytuacji gdy wartość własna czynnika jest mniejsza od 1, to oznacza, że wyjaśnia on mniej niż pojedyncza zmienna.

Na uwagę zasługuje także zasób zmienności wspólnej, która określa wielkość wariancji danej zmiennej wyjaśnioną za pomocą wybranej przez nas liczby czynników. W naszym modelu czynnikowym wszystkie zmienne mają wysoki zasób zmienności wspólnej, co świadczy o ich wysokiej przydatności. Czynniki interpretujemy, poddając analizie ładunki czynnikowe, które po rotacji są współczynnikami korelacji pomiędzy oryginalnymi zmiennymi a czynnikami. Spośród 18 wskaźników 6 ma wysokie ładunki na czynniku pierwszym. Czynnik 2 jest ładowany przez dwie zmienne, czynnik 3 przez trzy, czynnik 4 przez dwie, natomiast czynnik 5 i 6 przez jedną zmienną.

W celu ułatwienia oszacowania liczby czynników wykonano także wykres osypiska. Kryterium Keisera pozwala oszacować z góry liczbę czynników do 6 i dla tej maksymalnej liczby czynników wykonano wykres osypiska (rys. 3.4).

$\mathrm{Na}$ rys. 3.4. pokazano udział wyjaśnionej wariancji przez kolejne czynniki w całkowitej wariancji (w zasobie wariancji) wszystkich zmiennych i pozwala na oszacowanie liczby czynników. Można oszacować liczbę czynników z dołu, wymagając, aby nie brać tych czynników, których dodanie wyjaśnia mniej wariancji niż ilość wariancji przypadająca na jedną zmienną. Jeśli w danym zbiorze rzeczywiście istnieje w naturalny sposób struktura czynnikowa, to liczbę czynników można oszacować poprzez znalezienie punktu przegięcia wykresu osypiska. Jeśli wariancja kolejnych czynników jest zbliżona i już nie spada (małe nachylenie linii), możemy podjąć decyzję o ograniczeniu liczby czynników. 


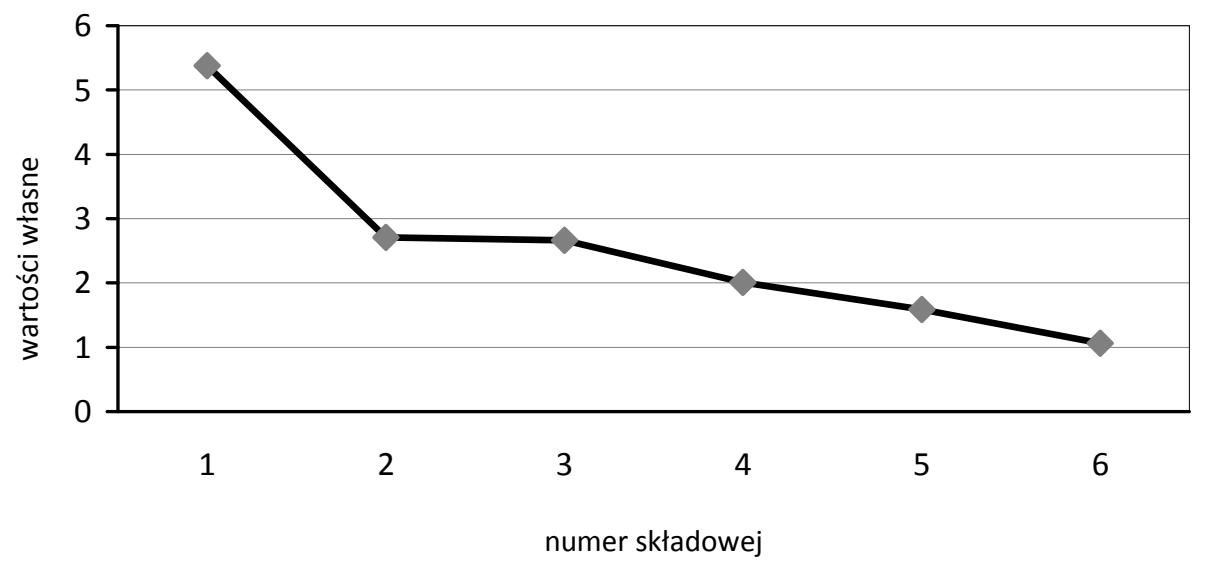

Rys. 3.4. Osypisko

Źródło: opracowanie własne.

Należy zauważyć, że nie ma obiektywnie najlepszego kryterium, podjęcie decyzji o wyborze liczby czynników w dużym stopniu zależy od celu analizy.

Po identyfikacji czynników następnym krokiem jest konieczność ich interpretacji, czyli nazwania; należy także pamiętać, że im większy ładunek, tym ważniejsza zmienna w danym czynniku. Interpretacja uzyskanych wyników możliwa jest wówczas, gdy zmienne tworzące poszczególne czynniki są spójne i tworzą pewnego rodzaju logiczną całość. W wyniku zastosowania analizy czynnikowej otrzymano cztery czynniki generowane przez zmienne opisujące sektor usług. Interpretacja otrzymanych czynników jest procesem subiektywnym.

W skład czynnika nazwanego NWDP weszły trzy zmienne: nakłady na działalność badawczą i rozwojową wskaźnik liczby pracujących w sektorze usług i wskaźnik wartości dodanej. Wskaźnik ten możemy określić jako czynnik strategiczny charakteryzujący rozwój sektora usług.

Czynnik drugi PPB, przyjmując w uproszczeniu, koncentruje się na pracy, czyli na liczbie pracujących w sektorze usług, podmiotach gospodarczych działających w tym sektorze oraz wskaźniku liczby bezrobotnych. Czynnikowi temu można przypisać rolę zmiennej skalującej kapitał ludzki.

W skład czynnika ILW weszły nakłady inwestycyjne, wskaźnik liczby ludności oraz wskaźnik przeciętnego wynagrodzenia w sektorze przedsiębiorstw. Jest to czynnik określający zasobność.

Czynnik 4 BNW składał się z bezrobotnych ogółem, wskaźnika nakładów na działalność badawczą i rozwojową oraz wskaźnika przeciętnych wydatków na 1 osobę. Niejednokrotnie pomimo przyjęcia, że zmienne generują faktyczne czynniki problemem jest ich interpretacja. 
W toku dalszej analizy wyznaczono wartość wskaźnika jednorodności (rzetelności) skali - $\alpha$ Cronbacha według wzoru (Wieczorkowska, Wierzbiński 2007):

$$
\alpha=\frac{k \bar{r}}{1+\bar{r}(k-1)}
$$

gdzie:

$\bar{r}$ - średnia z współczynników korelacji wszystkich zmiennych $X_{k}$,

$k$ - liczba zmiennych tworzących skalę.

Korzystając z pakietu statystycznego SPSS, otrzymano informacje o korelacji z wynikiem ogólnym i rzetelności (jednorodności) skali po wyeliminowaniu kolejno każdej zmiennej. Procedura taka pozwala na znalezienie zmiennych nieskorelowanych ze skalą $\mathrm{i}$ ich usunięcie.

Obliczono skalę Czynnik NWDP składającą się z trzech zmiennych. Rzetelność ( $\alpha$ Cronbacha) tej skali jest bardzo wysoka, równa 0,822 .

Charakterystyki statystyczne składowych wchodzących w skład skali $C z y n-$ nik NWDP oraz rzetelności tej skali policzone dla zmodyfikowanego klucza, w którym jeden item był pomijany, przedstawino w tab. 3.22.

Wyeliminowanie ze skali zmiennej „Nakłady na działalność badawczą i rozwojową (2010)" poprawiłoby rzetelność do wartości 0,834 .

Tablica 3.22. Analiza jednorodności skali

\begin{tabular}{|l|c|}
\hline \multicolumn{1}{|c|}{ Nazwa } & $\begin{array}{c}\text { Wskaźnik rzetelności } \\
\text { skali } \alpha \text { Cronbacha }\end{array}$ \\
\hline Czynnik NWDP & 0,822 \\
\hline Nakłady na działalność badawczą i rozwojową (2010) & 0,834 \\
\hline Wskaźnik liczby pracujących w sektorze usług & 0,686 \\
\hline Wskaźnik wartości dodanej usługi & 0,734 \\
\hline
\end{tabular}

Źródło: opracowanie własne.

Następnie obliczono skalę Czynnik $P P B$ składającą się z trzech zmiennych. Rzetelność ( $\alpha$ Cronbacha) tej skali jest bardzo wysoka, równa 0,834 .

Wyeliminowanie ze skali zmiennej „Wskaźnika liczby bezrobotnych” poprawiłoby rzetelność do wartości 0,887 .

Charakterystyki zmiennych wchodzących w skład skali Czynnik PPB oraz rzetelności tej skali, gdzie jedna zmienna była pomijana, przedstawiono w tab. 3.23. 
Tablica 3.23. Analiza jednorodności skali

\begin{tabular}{|l|c|}
\hline \multicolumn{1}{|c|}{ Nazwa } & $\begin{array}{c}\text { Wskaźnik rzetelności skali } \alpha \\
\text { Cronbacha }\end{array}$ \\
\hline Czynnik PPB & 0,834 \\
\hline Pracujący w sektorze usług (2010) & 0,797 \\
\hline Podmioty w sektorze usług (2010) & 0,588 \\
\hline Wskaźnik liczby bezrobotnych & 0,887 \\
\hline
\end{tabular}

Źródło: opracowanie własne.

W dalszej kolejności obliczono skalę Czynnik ILW składającą się z trzech zmiennych. Rzetelność ( $\alpha$ Cronbacha) tej skali jest wysoka, równa 0,793.

Wyeliminowanie ze skali itemu „Nakłady inwestycyjne w sektorze usług (2010)" poprawiłoby rzetelność do wartości 0,797.

Wielkości zmiennych wchodzących w skład skali Czynnik ILW oraz rzetelności tej skali, gdzie jedna zmienna była pomijana, przedstawiono w tab. 3.24.

Tablica 3.24. Analiza jednorodności skali

\begin{tabular}{|l|c|}
\hline \multicolumn{1}{|c|}{ Nazwa } & $\begin{array}{c}\text { Wskaźnik rzetelności skali } \alpha \\
\text { Cronbacha }\end{array}$ \\
\hline Czynnik ILW & 0,793 \\
\hline Nakłady inwestycyjne & 0,797 \\
\hline Wskaźnik liczby ludności & 0,668 \\
\hline Wskaźnik przeciętnego wynagrodzenia w sektorze usług & 0,685 \\
\hline
\end{tabular}

Źródło: opracowanie własne.

Obliczono skalę Czynnik $B N W$ składającą się z trzech zmiennych. Rzetelność ( $\alpha$ Cronbacha) tej skali jest umiarkowana, równa 0,593.

Wyeliminowanie ze skali zmiennej „Wzrost przeciętnych miesięcznych wydatków na 1 osobę" poprawiłoby rzetelność do wartości 0,719 .

Zmienne wchodzace w skład skali Czynnik $B N W$ oraz rzetelności tej skali, gdzie jedna zmienna była pomijana, przedstawiono w tab. 3.25.

Tablica 3.25. Analiza jednorodności skali

\begin{tabular}{|l|c|}
\hline \multicolumn{1}{|c|}{ Nazwa } & $\begin{array}{c}\text { Wskaźnik rzetelności skali } \alpha \\
\text { Cronbacha }\end{array}$ \\
\hline Czynnik BNW & 0,793 \\
\hline Bezrobotni ogółem & 0,797 \\
\hline Wskaźnik nakładów na działalność badawczą i rozwojową & 0,668 \\
\hline Wskaźnik przeciętnych miesięcznych wydatków & 0,685 \\
\hline
\end{tabular}

Źródło: opracowanie własne. 
Tablica 3.26. Wskaźniki rzetelności skali

\begin{tabular}{|c|c|c|c|c|}
\hline Lp. & Nazwa czynnika & $\mathrm{N}$ & $\alpha$ Cronbacha & Komentarz \\
\hline 1 & NWDP & 17 & 0,822 & Bardzo wysoka \\
\hline 2 & PPB & 17 & 0,834 & Bardzo wysoka \\
\hline 3 & ILW & 17 & 0,793 & Wysoka \\
\hline 4 & BNW & 17 & 0,593 & Umiarkowana \\
\hline
\end{tabular}

Źródło: opracowanie własne.

Wszystkie współczynniki - $\alpha$ Cronbacha są większe od 0,7 , co świadczy o dobrej akceptowanej rzetelności i spójności zaproponowanego zbioru itemów. Analiza czynnikowa zredukowała wejściowy zbiór 18 zmiennych do 4 czynników.

Analizę czynnikową zastosowano w celu stworzenia czynników, które powinny być brane pod uwagę w ocenie sektora usług. Analiza czynnikowa wskazała, które z nich w istotny sposób oddziałują na sektor usług. Pozwoliła także na wyeliminowanie czynników mało istotnych z szerokiego zbioru zmiennych. Otrzymane wyniki potwierdziły wcześniejsze przypuszczenia na temat znaczenia wielkości nakładów na działalność badawczo-rozwojową, co potwierdził czynnik 1. Czynnik 1 (NWDP) może być interpretowany jako czynnik strategiczny, określający rozwój sektora usług. Otrzymane wyniki pozwalają stwierdzić, że do oceny sektora usług można stosować znacznie szerszy zbiór wskaźników niż powszechnie stosowany.

\subsection{Sektor usług w przekroju województw}

Polska gospodarka od początku okresu transformacji przechodzi głębokie zmiany strukturalne, wynikiem których jest różny poziom rozwoju społecznogospodarczego poszczególnych województw. Problem badania relacji pomiędzy poziomem społeczno-gospodarczym regionów a rozwojem usług był podjęty w literaturze już w latach osiemdziesiątych ubiegłego stulecia (por. Styś, Olearnik 1985). Określenie poziomu społeczno-gospodarczego regionu jako niski, średni i wysoki jest podyktowane cechami działalności usługowej, typowymi dla danego poziomu. W celu zapewnienia pożądanych kierunków zmian w rozwoju powinny być zachowane określone proporcje zatrudnienia. Pomimo widocznej poprawy na rynku pracy w Polsce nadal obserwujemy znaczące różnice pomiędzy regionami. Na poziom zróżnicowania rozwoju poszczególnych województw wpływają czynniki o charakterze przestrzennym, które wynikają z położenia danego województwa, zasobów naturalnych, ludzkich, a także kapitałowych. 
$\mathrm{Z}$ dotychczas przeprowadzonych analiz wynika, że sektor usług jest dominującym sektorem gospodarki, co potwierdza udział w zatrudnieniu i wytwarzaniu wartości dodanej brutto. Jednakże w badaniach nad rozwojem sektora usług należy także zwrócić uwagę na zachodzące zmiany w przekroju województw. Metody oceny rozwoju regionów w literaturze prezentowane są między innymi przez Szymalę (2005), który podaje różne rodzaje mierników charakteryzujących regiony. Niejednokrotnie przyjmuje się, że za region o charakterze usługowym uznaje się taki, w którym co najmniej 50\% ludności pracuje w usługach (Godlewska-Majkowska 2010). W tab. 3.27 przedstawia strukturę pracujących w usługach według województw w latach 2005-2010.

Tablica 3.27. Struktura pracujących w sektorze usługach według województw w latach 2005-2010

\begin{tabular}{|l|c|c|c|c|c|c|}
\hline \multirow{2}{*}{ Nazwa województwa } & \multicolumn{7}{|c|}{ Pracujący w usługach (w \%) } \\
\cline { 2 - 7 } & 2005 & 2006 & 2007 & 2008 & 2009 & 2010 \\
\hline Dolnośląskie & 59,66 & 59,43 & 59,17 & 60,03 & 60,48 & 59,60 \\
\hline Kujawsko-pomorskie & 52,69 & 52,45 & 52,54 & 53,01 & 52,96 & 54,23 \\
\hline Lubelskie & 43,90 & 44,20 & 44,58 & 45,26 & 44,94 & 43,65 \\
\hline Lubuskie & 59,37 & 58,37 & 58,30 & 58,04 & 58,30 & 56,41 \\
\hline Łódzkie & 49,55 & 49,66 & 49,93 & 50,22 & 50,31 & 51,98 \\
\hline Małopolskie & 55,73 & 55,81 & 55,99 & 56,32 & 56,96 & 53,11 \\
\hline Mazowieckie & 63,09 & 62,87 & 63,35 & 64,37 & 65,51 & 66,48 \\
\hline Opolskie & 52,79 & 53,03 & 52,56 & 53,47 & 52,58 & 52,44 \\
\hline Podkarpackie & 47,38 & 47,35 & 47,30 & 48,48 & 48,50 & 42,27 \\
\hline Podlaskie & 45,53 & 45,41 & 45,74 & 46,51 & 46,23 & 47,76 \\
\hline Pomorskie & 60,58 & 60,03 & 59,78 & 60,30 & 60,69 & 61,12 \\
\hline Śląskie & 57,57 & 57,41 & 57,50 & 57,37 & 57,76 & 57,04 \\
\hline Śiętokrzyskie & 44,64 & 44,40 & 44,24 & 45,59 & 44,54 & 43,76 \\
\hline Warmińsko-mazurskie & 54,09 & 53,73 & 53,29 & 54,47 & 54,10 & 53,89 \\
\hline Wielkopolskie & 50,31 & 50,66 & 50,85 & 51,44 & 51,98 & 52,14 \\
\hline Zachodniopomorskie & 63,23 & 62,87 & 62,53 & 63,40 & 63,84 & 63,32 \\
\hline POLSKA & 55,01 & 54,93 & 55,05 & 55,69 & 56,06 & 55,36 \\
\hline
\end{tabular}

Źródło: opracowanie własne.

W latach 2005-2010 średnie roczne tempo wzrostu liczby pracujących ogółem wynosiło $2 \%$, przykładowo dla województwa małopolskiego $2,7 \%$, mazowieckiego $2,6 \%$, dolnośląskiego $2,4 \%$, pomorskiego $2,4 \%$ i wielkopolskiego także $2,4 \%$ (por. tab. 3.28). 
Tablica 3.28. Pracujący w sektorze usług według województw w latach 2005-2011

\begin{tabular}{|l|c|c|c|c|c|c|c|}
\hline \multirow{2}{*}{$\begin{array}{c}\text { Nazwa } \\
\text { województwa }\end{array}$} & 2006 & 2007 & 2008 & 2009 & 2010 & $\begin{array}{c}\text { Indeks } \\
2005=100\end{array}$ & $\begin{array}{c}\text { Średnia } \\
\text { geome- } \\
\text { tryczna }\end{array}$ \\
\cline { 2 - 6 } & 102,99 & 105,45 & 105,55 & 97,81 & 100,20 & 112,35 & 102,4 \\
\hline Dolnośląskie & 102,52 & 104,71 & 102,67 & 96,63 & 101,46 & 108,06 & 101,6 \\
\hline Kujawsko-pomorskie & 102,31 & 103,11 & 103,05 & 98,02 & 101,55 & 108,21 & 101,6 \\
\hline Lubelskie & 102,02 & 104,13 & 100,27 & 97,72 & 101,00 & 105,14 & 101,0 \\
\hline Lubuskie & 102,72 & 104,77 & 101,69 & 96,78 & 103,97 & 110,11 & 101,9 \\
\hline Łódzkie & 102,67 & 104,58 & 103,17 & 101,12 & 101,91 & 114,16 & 102,7 \\
\hline Małopolskie & 102,02 & 105,65 & 103,17 & 101,95 & 100,08 & 113,47 & 102,6 \\
\hline Mazowieckie & 103,09 & 102,69 & 104,56 & 94,88 & 100,00 & 105,02 & 101,0 \\
\hline Opolskie & 102,31 & 103,45 & 104,49 & 96,63 & 102,13 & 109,15 & 101,8 \\
\hline Podkarpackie & 101,42 & 104,91 & 103,67 & 97,07 & 100,53 & 107,64 & 101,5 \\
\hline Podlaskie & 102,62 & 104,05 & 102,90 & 100,72 & 101,81 & 112,67 & 102,4 \\
\hline Pomorskie & 102,26 & 104,04 & 101,64 & 98,20 & 101,51 & 107,79 & 101,5 \\
\hline Śląskie & 101,39 & 102,74 & 105,74 & 94,11 & 99,70 & 103,35 & 100,7 \\
\hline Świętokrzyskie & 101,63 & 103,12 & 103,24 & 95,95 & 102,33 & 106,24 & 101,2 \\
\hline Warmińnko-mazurskie & 103,49 & 105,23 & 102,18 & 99,43 & 101,63 & 112,44 & 102,4 \\
\hline Wielkopolskie & 102,75 & 103,37 & 103,85 & 96,09 & 99,14 & 105,07 & 101,0 \\
\hline Zachodniopomorskie & 102,45 & 104,51 & 103,06 & 98,74 & 101,17 & 110,25 & 102,0 \\
\hline POLSKA & & & & & & &
\end{tabular}

Źródło: opracowanie własne.

W roku 2005 największym udziałem pracujących w usługach przekraczającym $50 \%$ charakteryzowały się województwa: wielkopolskie - 50,31\%, opolskie - 52,79\%, kujawsko-pomorskie - 52,69, warmińsko-mazurskie - 54,09\%, małopolskie $-55,73 \%$, śląskie $-57,57 \%$, lubuskie $-59,37 \%$, dolnośląskie $-59,66 \%$, pomorskie - 60,58\%, mazowieckie - 63,09, zachodniopomorskie - 63,23\%. Najmniejszy udział odnotowano w województwach: lubelskim - 43,9\%, świętokrzyskim - 44,64\%, podlaskim - 45,53\%, podkarpackim - 47,38\% i łódzkim $49,55 \%$. W roku 2006 w porównaniu z rokiem 2005 we wszystkich województwach zanotowano wzrost pracujących w usługach, był on jednak niewielki, bo wahał się od 1,39 do 3,49\%. W roku 2006 udział pracujących w usługach w ogólnej liczbie pracujących kształtował się podobnie jak w roku 2005. W roku 2007 największą dynamikę wzrostu liczby osób pracujących zanotowano w województwach: wielkopolskim - o 5,23\%, dolnośląskim - o 5,45\% i mazowieckim - o 5,65\%. Natomiast najmniejszy wzrost odnotowano w województwach: opolskim - o 2,69\% i świętokrzyskim o 2,74\%. Udział pracujących w usługach wyglądał podobnie jak w roku 2006 i 2005 , nadal dominowały te same województwa. 


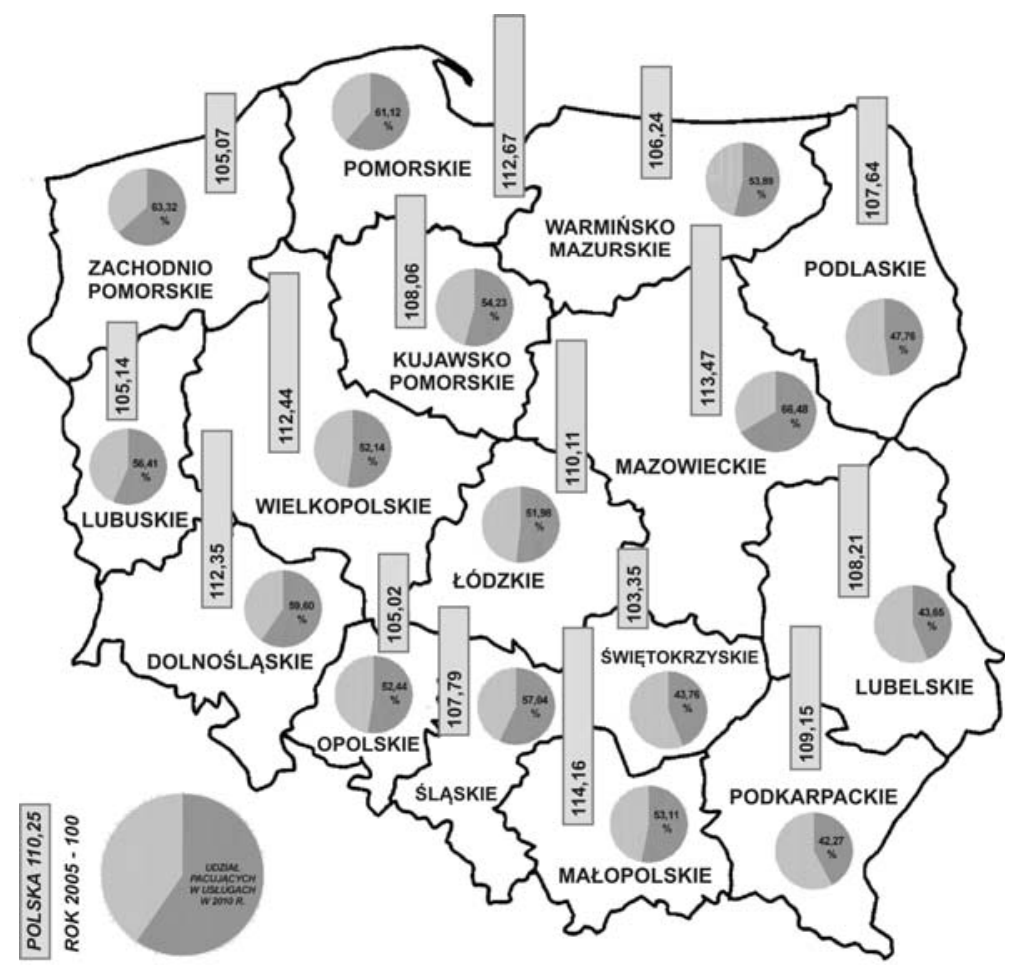

Rys. 3.5. Struktura pracujących w usługach wg województw w latach 2005-2010 Źródło: opracowanie własne.

Pewne zmiany zaszły w roku 2008 zarówno w dynamice, jak i w udziale pracujących. Najmniejsza dynamika pracujących została zaobserwowana w województwie lubuskim - wzrost o $0,27 \%$, natomiast w województwie dolnośląskim udział pracujących w usługach przekroczył $60 \%$ ogółu pracujących w kraju; niewiele ponad $50 \%$ zanotowano w województwie łódzkim; dominującym województwem jest nadal mazowieckie przekraczające $64 \%$. W roku 2009 prawie w każdym z województw nastąpił spadek liczby pracujących w stosunku do roku poprzedniego. Wzrost w stosunku do 2008 r. odnotowano tylko w województwie: małopolskim o $1,12 \%$, mazowieckim o $1,95 \%$ i pomorskim o $0,72 \%$. Udział pracujących w usługach w porównaniu do roku 2008 nie wykazywał istotnych zmian. Nieco lepiej wyglądała sytuacja w 2010 r. niewielki spadek liczby osób pracujących w porównaniu do roku wcześniejszego miał miejsce w województwie świętokrzyskim i zachodniopomorskim, w województwie opolskim sytuacja nie uległa zmianie. Słaby wzrost zaobserwowano w województwie dolnośląskim - o $0,2 \%$, podlaskim - o $0,53 \%$ i mazowieckim o $0,8 \%$. Niewielki spadek udziału pracujących zaobserwowano w województwie dolno- 
śląskim, w kujawsko-pomorskim nastapił wzrost z 52,96\% w 2009 do 54,23\% w 2010 r., w województwie lubelskim miał miejsce niewielki spadek, zaś w lubuskim spadek wyniósł $2 \%$. Województwo łódzkie wykazało niewielki wzrost z 50,31\% w 2009 do 51,98\% w 2010 r., w małopolskim spadek z 56,96 do $53,11 \%$, w mazowieckim niewielki wzrost o około $1 \%$. W województwach: opolskim, podlaskim i świętokrzyskim udział pracujących w sektorze usług podobnie jak $\mathrm{w}$ latach wcześniejszych nie przekroczył $50 \%$, ponad $60 \%$ udział osiągnęło województwo pomorskie i zachodniopomorskie. W roku $2010 \mathrm{w}$ porównaniu z rokiem 2005 największą dynamikę wzrostu liczby osób pracujących osiągnęły województwa: małopolskie - o 14,16\%, mazowieckie - o 13,47\%, pomorskie - o 12,67\%, wielkopolskie - o 12,44\% i dolnośląskie - o 12,35\%, najmniejszy wzrost osiągnęło województwo świętokrzyskie - o 3,35\%.

W latach 2005-2010 ponad 50\% udział liczby pracujących w sektorze usług, świadczący o usługowym charakterze, osiągnęły województwa: dolnośląskie, kujawsko-pomorskie, lubuskie, od 2008 roku łódzkie, małopolskie, mazowieckie, opolskie, pomorskie, śląskie, warmińsko-mazurskie, wielkopolskie i zachodniopomorskie. W grupie tej były także województwa, w których udział pracujących w usługach przekroczył $60 \%$, tj. województwa: mazowieckie, pomorskie, zachodniopomorskie; poziom ten starało się także osiagnąć województwo dolnośląskie.

We wszystkich województwach udział usług w strukturze pracujących jest bardzo wysoki. Przyglądając się strukturze pracujących w poszczególnych sekcjach usługowych w badanym okresie, zdecydowanie największy udział w ogólnej liczbie pracujących w każdym z województw wykazały handel i naprawy, na drugim miejscu była działalność związana z obsługą rynku nieruchomości. Wymienione sekcje ze względu na udział pracujących w nich osób dominują w województwach posiadających duże skupiska miejskie, są to województwa mazowieckie, śląskie, dolnośląskie i zachodniopomorskie. Znaczny udział pracujących zanotowano także w sekcji związanej z zakwaterowaniem i usługami gastronomicznymi, zwłaszcza $\mathrm{w}$ województwach $\mathrm{z}$ dużym udziałem przedsiębiorstw, czyli w województwie: zachodniopomorskim, małopolskim i pomorskim. W tab. 3.29 przedstawiono strukturę wartość dodanej brutto w sektorze usług według województw w latach 2005-2010.

W celu wyznaczenia średniego rocznego tempa zmian wartości dodanej brutto w latach 2005-2010 skorzystano ze średniej geometrycznej dla danych w postaci indeksów łańcuchowych. W badanym okresie średnie roczne tempo wzrostu badanego wskaźnika ogółem wyniosło 8,1\% (por. tab. 3.30). 
Tablica 3.29. Struktura wartości dodanej brutto (WDB) w sektorze usług według województw w latach 2005-2010

\begin{tabular}{|l|c|c|c|c|c|c|}
\hline \multirow{2}{*}{$\begin{array}{c}\text { Nazwa } \\
\text { województwa }\end{array}$} & \multicolumn{7}{|c|}{ WDB w usługach (w \%) } \\
\cline { 2 - 7 } & 2005 & 2006 & 2007 & 2008 & 2009 & 2010 \\
\hline Dolnośląskie & 62,04 & 59,92 & 58,17 & 59,90 & 57,98 & 60,58 \\
\hline Kujawsko-pomorskie & 63,75 & 63,46 & 62,37 & 63,47 & 61,47 & 63,74 \\
\hline Lubelskie & 68,27 & 68,20 & 66,71 & 66,67 & 66,07 & 65,22 \\
\hline Lubuskie & 62,04 & 62,09 & 60,40 & 61,82 & 58,74 & 62,03 \\
\hline Łódzkie & 62,54 & 62,35 & 61,20 & 61,66 & 58,80 & 61,28 \\
\hline Małopolskie & 67,93 & 66,44 & 65,48 & 66,37 & 65,56 & 66,48 \\
\hline Mazowieckie & 75,14 & 74,83 & 75,19 & 75,69 & 75,33 & 76,58 \\
\hline Opolskie & 59,49 & 60,89 & 58,42 & 57,69 & 58,55 & 54,42 \\
\hline Podkarpackie & 63,60 & 63,96 & 63,52 & 63,30 & 63,08 & 62,48 \\
\hline Podlaskie & 64,42 & 64,96 & 63,11 & 65,14 & 62,93 & 65,69 \\
\hline Pomorskie & 68,36 & 67,06 & 65,99 & 67,33 & 65,21 & 67,92 \\
\hline Śląskie & 59,62 & 59,95 & 59,65 & 58,89 & 57,81 & 57,72 \\
\hline Świętokrzyskie & 64,45 & 63,10 & 60,01 & 59,48 & 58,02 & 56,06 \\
\hline Warmińsko-mazurskie & 64,18 & 64,14 & 62,57 & 63,72 & 60,04 & 63,39 \\
\hline Wielkopolskie & 59,62 & 58,95 & 59,32 & 59,84 & 58,21 & 60,26 \\
\hline Zachodniopomorskie & 71,30 & 70,98 & 69,96 & 70,10 & 68,12 & 69,19 \\
\hline POLSKA & 65,99 & 65,57 & 154,13 & 65,34 & 64,05 & 65,28 \\
\hline
\end{tabular}

Źródło: opracowanie własne.

Tablica 3.30. Wartość dodana brutto (WDB) w sektorze usług według województw w latach 2005-2011

\begin{tabular}{|l|c|c|c|c|c|c|c|}
\hline \multirow{2}{*}{$\begin{array}{c}\text { Nazwa } \\
\text { województwa }\end{array}$} & 2006 & 2007 & 2008 & 2009 & 2010 & $\begin{array}{c}\text { Indeks } \\
2005 \\
=100\end{array}$ & $\begin{array}{c}\text { Średnia } \\
\text { geome- } \\
\text { tryczna }\end{array}$ \\
\cline { 2 - 8 } & 107,36 & 108,95 & 110,36 & 104,81 & 109,12 & 147,63 & 107,5 \\
\hline Dolnośląskie & 107,24 & 107,91 & 109,95 & 101,50 & 111,12 & 143,50 & 106,0 \\
\hline Kujawsko-pomorskie & 105,99 & 108,18 & 110,74 & 102,28 & 102,98 & 133,75 & 106,1 \\
\hline Lubelskie & 106,12 & 107,14 & 107,52 & 101,11 & 108,98 & 134,70 & 107,1 \\
\hline Lubuskie & 106,76 & 108,20 & 110,27 & 99,74 & 111,06 & 141,10 & 108,0 \\
\hline Lódzkie & 107,10 & 107,92 & 110,97 & 105,26 & 108,94 & 147,07 & 108,5 \\
\hline Małopolskie & 108,26 & 111,72 & 107,91 & 108,33 & 106,35 & 150,38 & 105,2 \\
\hline Mazowieckie & 106,31 & 108,96 & 109,01 & 104,13 & 98,07 & 128,95 & 106,2 \\
\hline Opolskie & 107,18 & 108,31 & 110,59 & 105,83 & 99,65 & 135,39 & 107,7 \\
\hline Podkarpackie & 107,19 & 108,34 & 109,97 & 104,06 & 108,93 & 144,77 & 106,8 \\
\hline Podlaskie & 105,99 & 109,09 & 107,06 & 106,57 & 105,22 & 138,81 & 106,1 \\
\hline Pomorskie & 106,04 & 109,71 & 108,62 & 104,02 & 102,41 & 134,61 & 106,0 \\
\hline Śląskie & 106,64 & 106,06 & 111,47 & 100,94 & 104,96 & 133,56 & 106,8 \\
\hline Świętokrzyskie & 106,09 & 106,16 & 110,11 & 100,19 & 112,07 & 139,25 & 107,7 \\
\hline Warmińsko-mazurskie & 104,95 & 110,68 & 109,57 & 106,16 & 107,36 & 145,06 & 105,4 \\
\hline Wielkopolskie & 105,03 & 107,35 & 109,82 & 100,60 & 104,26 & 129,87 & 107,3 \\
\hline Zachodniopomorskie & 106,80 & 109,38 & 109,22 & 104,82 & 106,38 & 142,27 & 108,1 \\
\hline POLSKA & & & & & & \\
\hline
\end{tabular}

Źródło: opracowanie własne. 


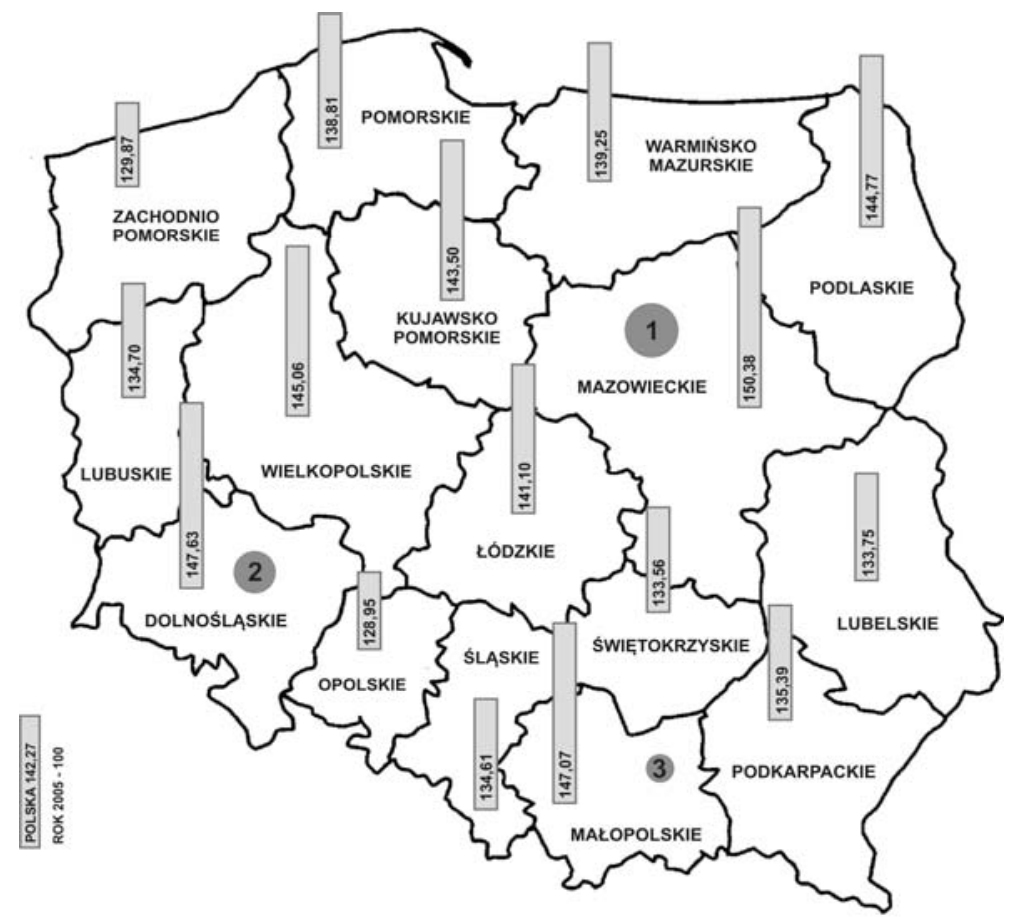

Rys. 3.6. Wartość dodana brutto w sektorze usług według województw w latach 2005-2010 Źródło: opracowanie własne.

Najwyższą wartość dodaną w badanym okresie generowało województwo mazowieckie. Prawie w każdym roku udział wartości dodanej w tym województwie w sektorze usług przekroczył $75 \%$ wartości dodanej ogółem. Najniższą wartość dodaną w sektorze usług wytworzyło województwo śląskie, jej udział w wartości dodanej ogółem nie przekroczył $60 \%$. Systematycznie z roku na rok w większości województw zaobserwowano wzrost dynamiki.

O rozwoju sektora usług w poszczególnych województwach świadczy duża liczba firm działających w tym sektorze. We wszystkich województwach, w każdym roku udział podmiotów gospodarczych zarejestrowanych w rejestrze REGON (tab. 3.31), w sektorze usług przekraczał $70 \%$ ogólnej liczby wszystkich podmiotów. Najwyższy udział w 2010 r. uzyskały województwa: mazowieckie $(78,63 \%)$, dolnośląskie $(78,7 \%)$, i śląskie $(77,42 \%)$. Wysoki udział wykazały także województwa: lubelskie i lubuskie. Porównanie udziału przedsiębiorstw usługowych w województwach świadczy, że sektor usług stanowi także podstawę gospodarki województw o niższym poziomie rozwoju. Warunkiem konkurencyjności województw prowadzącym do wzrostu dobrobytu mieszkańców poszczególnych regionów jest zadbanie o wysoki poziom innowacyjności podmiotów funkcjonujących w sektorze usług. 
Tablica 3.31. Struktura podmiotów gospodarczych zarejestrowanych w rejestrze REGON w sektorze usług według województw w latach 2005-2010

\begin{tabular}{|l|c|c|c|c|c|c|}
\hline \multirow{2}{*}{ Nazwa województwa } & \multicolumn{7}{|c|}{ Podmioty gospodarcze w usługach w \% } \\
\cline { 2 - 7 } & 2005 & 2006 & 2007 & 2008 & 2009 & 2010 \\
\hline Dolnośląskie & 79,07 & 79,01 & 78,52 & 78,11 & 78,08 & 77,94 \\
\hline Kujawsko-pomorskie & 77,23 & 77,04 & 76,58 & 76,24 & 76,09 & 75,84 \\
\hline Lubelskie & 79,20 & 78,92 & 78,47 & 77,98 & 77,64 & 77,14 \\
\hline Lubuskie & 78,89 & 78,40 & 77,52 & 76,82 & 76,34 & 76,04 \\
\hline Łódzkie & 74,84 & 74,82 & 74,47 & 74,21 & 74,26 & 74,31 \\
\hline Małopolskie & 75,41 & 75,34 & 74,78 & 74,23 & 74,33 & 74,10 \\
\hline Mazowieckie & 77,82 & 78,03 & 77,98 & 77,93 & 78,62 & 78,63 \\
\hline Opolskie & 76,05 & 75,77 & 75,09 & 74,34 & 74,02 & 73,64 \\
\hline Podkarpackie & 77,13 & 77,01 & 76,68 & 76,07 & 75,80 & 75,22 \\
\hline Podlaskie & 76,28 & 76,21 & 75,61 & 74,93 & 74,93 & 74,72 \\
\hline Pomorskie & 75,08 & 74,35 & 73,72 & 73,42 & 73,76 & 74,20 \\
\hline Śląskie & 78,57 & 78,53 & 78,15 & 77,84 & 77,76 & 77,42 \\
\hline Świętokrzyskie & 77,88 & 77,66 & 77,25 & 76,57 & 76,02 & 75,51 \\
\hline Warmińsko-mazurskie & 77,45 & 76,96 & 76,17 & 75,34 & 75,19 & 75,00 \\
\hline Wielkopolskie & 73,82 & 73,64 & 73,02 & 72,59 & 72,89 & 72,85 \\
\hline Zachodniopomorskie & 78,34 & 77,75 & 77,00 & 76,57 & 76,39 & 76,19 \\
\hline Ogółem & 70,02 & 76,89 & 76,44 & 76,05 & 76,14 & 75,99 \\
\hline
\end{tabular}

Źródło: obliczenia własne.

Tablica 3.32. Podmioty gospodarcze zarejestrowane w rejestrze REGON w sektorze usług według województw w latach 2005-2011

\begin{tabular}{|c|c|c|c|c|c|c|c|}
\hline \multirow[b]{2}{*}{ Nazwa województwa } & \multicolumn{5}{|c|}{ Indeks łańcuchowy } & \multirow{2}{*}{$\begin{array}{c}\text { Indeks } \\
2005=100\end{array}$} & \multirow{2}{*}{$\begin{array}{l}\text { Średnia } \\
\text { geome- } \\
\text { tryczna }\end{array}$} \\
\hline & 2006 & 2007 & 2008 & 2009 & 2010 & & \\
\hline Dolnośląskie & 100,07 & 101,10 & 102,19 & 99,99 & 104,37 & 107,89 & 101,5 \\
\hline Kujawsko-pomorskie & 99,61 & 100,24 & 101,48 & 94,53 & 101,84 & 97,56 & 99,5 \\
\hline Lubelskie & 100,70 & 100,05 & 101,39 & 100,59 & 104,38 & 107,25 & 101,4 \\
\hline Lubuskie & 102,78 & 99,70 & 94,83 & 98,93 & 104,24 & 100,21 & 100,0 \\
\hline Łódzkie & 96,66 & 99,39 & 100,23 & 91,16 & 104,70 & 91,91 & 98,3 \\
\hline Małopolskie & 99,78 & 100,79 & 101,87 & 104,26 & 105,20 & 112,38 & 102,4 \\
\hline Mazowieckie & 101,57 & 102,83 & 103,46 & 100,47 & 105,32 & 114,35 & 102,7 \\
\hline Opolskie & 102,10 & 101,33 & 100,37 & 98,77 & 103,28 & 105,93 & 101,2 \\
\hline Podkarpackie & 101,00 & 100,55 & 100,76 & 100,15 & 104,44 & 107,04 & 101,4 \\
\hline Podlaskie & 99,92 & 98,91 & 100,86 & 99,27 & 102,28 & 101,21 & 100,2 \\
\hline Pomorskie & 100,17 & 100,80 & 102,89 & 104,12 & 105,01 & 113,58 & 102,6 \\
\hline Śląskie & 99,77 & 99,96 & 99,95 & 100,28 & 104,44 & 104,40 & 100,9 \\
\hline Świętokrzyskie & 101,52 & 100,03 & 100,51 & 96,79 & 102,17 & 100,94 & 100,2 \\
\hline Warmińsko-mazurskie & 100,48 & 100,52 & 101,32 & 98,95 & 103,40 & 104,71 & 100,9 \\
\hline Wielkopolskie & 101,05 & 101,05 & 101,90 & 99,93 & 104,43 & 108,58 & 101,7 \\
\hline Zachodniopomorskie & 100,55 & 99,63 & 100,56 & 100,68 & 102,21 & 103,66 & 100,7 \\
\hline Ogółem & 110,43 & 100,77 & 101,42 & 99,73 & 104,27 & 117,36 & 103,3 \\
\hline
\end{tabular}

Źródło: obliczenia własne. 


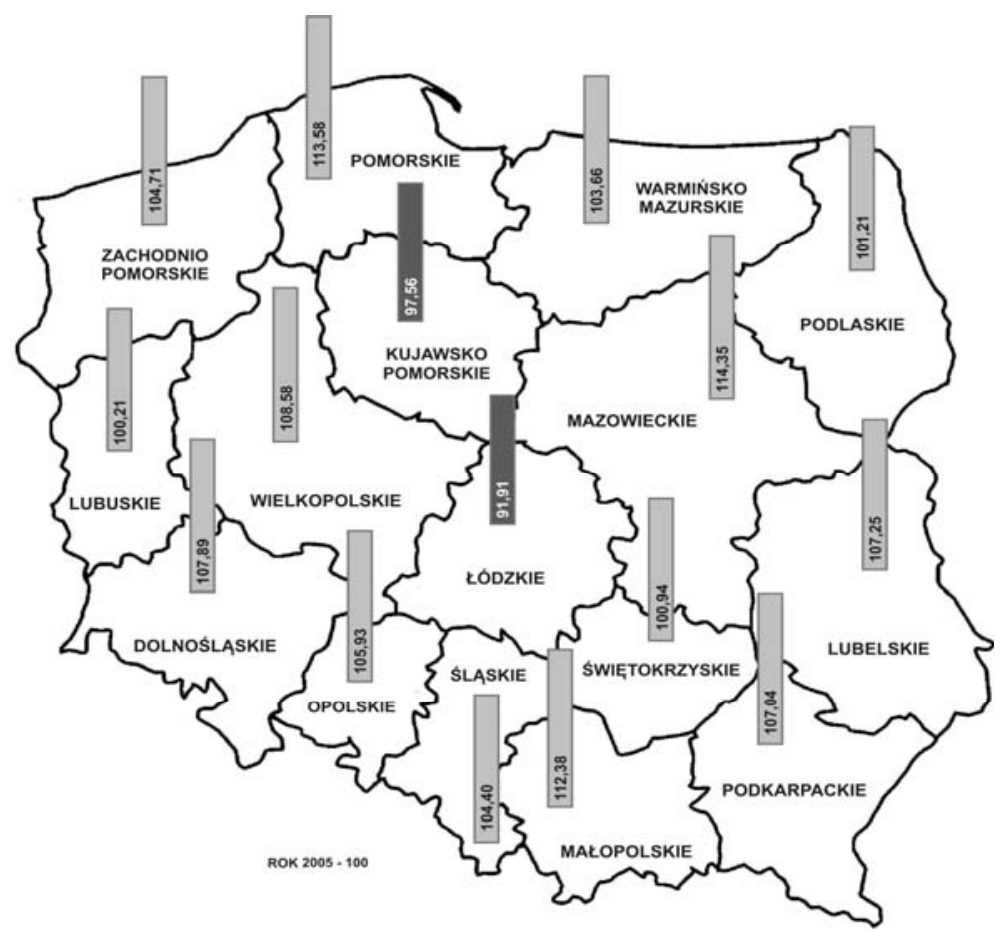

Rys. 3.7. Podmioty gospodarcze zarejestrowane w rejestrze REGON w sektorze usług według województw w latach 2005-2010

Źródło: opracowanie własne.

Tablica 3.33 zawiera informacje na temat struktury podmiotów gospodarczych w sekcjach usługowych w układzie województw. Najwyższy udział wykazują województwa: mazowieckie $(78,9)$, dolnośląskie $(78,7 \%)$ i śląskie (78,7\%). We wszystkich największy udział ma sekcja G (handel i naprawy), choć $\mathrm{w}$ porównaniu $\mathrm{z}$ latami wcześniejszymi można zaobserwować spadek udziału przedsiębiorstw funkcjonujących w tej sekcji. Sytuacja taka może być wynikiem wzrostu konkurencji oraz zmianami, wynikającymi z zapotrzebowania społeczeństwa na różne rodzaje usług czy też z naśladowania społeczeństw państw wysoko rozwiniętych. W województwie świętokrzyskim udział przedsiębiorstw zarejestrowanych $\mathrm{w}$ sekcji $\mathrm{G}$ wyniósł 45,1\%, w łódzkim 40,3\%, a w lubelskim 39,7\%. W sekcji $\mathrm{H}$ najwięcej było przedsiębiorstw zarejestrowanych w województwie podlaskim $(10,1)$. W usługach związanych $\mathrm{z}$ zakwaterowaniem i gastronomią wysoki udział w porównaniu $\mathrm{z}$ innymi województwami wykazały województwa zachodniopomorskie $(6,0 \%)$ i małopolskie $(5,2 \%)$. W usługach związanych z informacją i komunikacją (sekcja J) przodowało województwo mazowieckie $(5,3 \%)$. Udział podmiotów w zakresie działalności finansowej i ubezpieczeniowej był podobny we wszystkich województwach. 
Znaczne zróżnicowanie było w przypadku działalności związanej z obsługą nieruchomości zwłaszcza w województwie dolnośląskim (14,0\%), opolskim (11\%) i warmińsko-mazurskim $(11,9)$.

Udział przedsiębiorstw sekcji $\mathrm{M}$ związanej z działalnością profesjonalną, naukową i techniczną $\mathrm{w}$ przedsiębiorstwach usługowych $\mathrm{w}$ poszczególnych województwach kształtował się w granicach od 8,6\% w województwie lubuskim do $12,0 \% \mathrm{w}$ województwie wielkopolskim. W przypadku usług należących do sekcji $\mathrm{N}$ dominowało województwo mazowieckie (4\%) a najniższy udział wykazało województwo świętokrzyskie (1,9\%). Najniższy udział wśród wszystkich sekcji usługowych wykazała działalność związana $\mathrm{z}$ administracją publiczną, obroną narodową oraz obowiązkowymi ubezpieczeniami społecznymi (sekcja O). W porównaniu z innymi latami we wszystkich województwach uwagę zwraca wzrost udziału podmiotów funkcjonujących w sekcji ochrona zdrowia i opieka społeczna (sekcja Q), co może być wynikiem starzenia się społeczeństwa, wydłużonym wiekiem emerytalnym lub większą świadomością dbania o zdrowie. W przypadku pozostałych sekcji brak większego zróżnicowania w poszczególnych województwach. Wysoki udział niektórych sekcji w poszczególnych województwach może wynikać z różnic terytorialnych. Różnice te mogą być spowodowane nie tylko poziomem rozwoju, ale także położeniem czy kulturą danego regionu.

Tablica 3.33. Udział (w \%) podmiotów gospodarczych w sekcjach usługowych według województw w $2010 \mathrm{r}$.

\begin{tabular}{|c|c|c|c|c|c|c|c|c|c|c|c|c|c|c|}
\hline \multirow{2}{*}{$\begin{array}{c}\text { Nazwa } \\
\text { województwa }\end{array}$} & \multicolumn{13}{|c|}{ Sekcje usługowe } & \multirow{2}{*}{$\begin{array}{l}\text { Ra- } \\
\text { zem }\end{array}$} \\
\hline & $\mathrm{G}$ & $\mathrm{H}$ & I & $\mathrm{J}$ & $\mathrm{K}$ & $\mathrm{L}$ & $\mathrm{M}$ & $\mathrm{N}$ & $\mathrm{O}$ & $\mathrm{P}$ & $\mathrm{Q}$ & $\mathrm{R}$ & $\mathrm{S}$ & \\
\hline olska & 36,7 & 9,0 & 3,9 & 3,2 & 4,4 & 6,9 & 11,2 & 3,1 & 1,0 & 4,0 & 6,4 & 2,3 & 8,1 & 76,4 \\
\hline Dolnośląskie & 3,5 & 8,1 & 3,8 & 2,9 & 4,2 & 14,0 & 11,1 & 2,8 & 0,6 & 3,4 & 5,7 & 2,1 & 7,7 & 8,7 \\
\hline Kujawsko-pon & 8,1 & 9,6 & 3,1 & 2,5 & 4,8 & 5,6 & 9,3 & 2,9 & 1,1 & 3,9 & 8,3 & 2,4 & 8,6 & 76,5 \\
\hline Lubelskie & 9,7 & 9,3 & 3,4 & 2,2 & 4,4 & 3,6 & 9,3 & 2,5 & 2,1 & 4,7 & 7,3 & 2,1 & 9,0 & 77,8 \\
\hline Lubuskie & 6,7 & 9,2 & 4,0 & 2,1 & 4,1 & 6,6 & 8,6 & 2,6 & 0,9 & 3,5 & 6,3 & 2,2 & 8,2 & 76,9 \\
\hline & 0,3 & 8,7 & 3,2 & 2,7 & 4,3 & 4,7 & 10,1 & 2,8 & 1,3 & 4,1 & 6,3 & 2,3 & 8,6 & 75,2 \\
\hline & 6,5 & 9,3 & 5,2 & 3,3 & 4,0 & 3,6 & 11,5 & 3,2 & 0,9 & 4,3 & 6,5 & 2,6 & 8,0 & 74,5 \\
\hline Mazowieckie & 5,1 & 9,1 & 3,0 & 5,3 & 4,4 & 5,2 & 14,6 & 4,0 & 0,7 & 3,9 & 5,2 & 1,9 & 7,5 & 78,9 \\
\hline Opo & 5,7 & 7,3 & 4,1 & 2,2 & 4,7 & 11,0 & 10,5 & 3,0 & 1,3 & 4,0 & 5,8 & 2,5 & 8,0 & 74,3 \\
\hline 1 & 9,5 & 9,3 & 3,6 & 2,5 & 3,8 & 3,4 & 10,1 & 2,0 & 1,8 & 5,1 & 6,8 & 2,8 & 9,3 & 75,6 \\
\hline 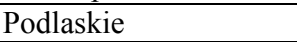 & 7,2 & 10,1 & 2,9 & 2,2 & 4,5 & 3,5 & 10,0 & 2,3 & 1,6 & 4,0 & 8,0 & 2,4 & 9,9 & 76,5 \\
\hline iie & 2,3 & 9,6 & 5,5 & 3,1 & 4,7 & 9,8 & 11,4 & 2,9 & 0,7 & 3,8 & 6,3 & 2,2 & 7,8 & 74,4 \\
\hline Śląskie & 39,3 & 8,9 & 4,2 & 2,8 & 4,7 & 6,6 & 10,3 & 2,9 & 0,5 & 3,9 & 5,8 & 2,2 & 7,6 & 77,9 \\
\hline Świętokrzyskie & 45,1 & 9,4 & 3,5 & 2,0 & 4,1 & 3,6 & 8,8 & 1,9 & 1,7 & 3,8 & 5,9 & 1,9 & 8,1 & 76,0 \\
\hline Warmińsko-m & 32,1 & 8,3 & 3,4 & 2,0 & 4,1 & 11,9 & 8,9 & 2,7 & 1,4 & 4,4 & 8,6 & 2,5 & 9,6 & 75,7 \\
\hline Wielkopolskie & 37,8 & 8,6 & 3,1 & 3,0 & 4,2 & 5,0 & 12,0 & 3,3 & 1,1 & 4,1 & 6,9 & 2,2 & 8,5 & 73,3 \\
\hline Zachodniopomo & 34,0 & 9,2 & 6,0 & 2,2 & 4,2 & 9,3 & 9,8 & 3,5 & 0,7 & 3,3 & 8,0 & 2,3 & 7,5 & 76,5 \\
\hline
\end{tabular}

Źródło: Słomińska (red), (2011), Usługi w Polsce 2008-2010, Raporty, Wyd. Instytut Badań Rynku, Konsumpcji i Koniunktur. 
W toku dalszej analizy, korzystając ze wskaźnika podaży usług, wyznaczono jego wartości dla poszczególnych województw w latach 2005-2011. Dane przedstawiono $\mathrm{w}$ tab. 3.34 .

Tablica 3.34.Wskaźnik podaży usług

\begin{tabular}{|l|c|c|c|c|c|c|c|}
\hline \multirow{2}{*}{$\begin{array}{c}\text { Nazwa } \\
\text { województwa }\end{array}$} & \multicolumn{7}{|c|}{ Wskaźniki podaży usług } \\
\cline { 2 - 9 } & 2005 & 2006 & 2007 & 2008 & 2009 & 2010 & 2011 \\
\hline Dolnośląskie & 1,16 & 1,17 & 1,17 & 1,22 & 1,3 & 1,24 & 1,23 \\
\hline Kujawsko-pomorskie & 0,85 & 0,85 & 0,86 & 0,87 & 0,91 & 0,97 & 0,96 \\
\hline Lubelskie & 0,6 & 0,6 & 0,61 & 0,63 & 0,64 & 0,61 & 0,6 \\
\hline Lubuskie & 1,13 & 1,09 & 1,1 & 1,08 & 1,16 & 1,05 & 1,07 \\
\hline Łódzkie & 0,75 & 0,77 & 0,79 & 0,79 & 0,84 & 0,89 & 0,9 \\
\hline Małopolskie & 1,01 & 1,02 & 1,04 & 1,06 & 1,11 & 0,92 & 0,93 \\
\hline Mazowieckie & 1,47 & 1,46 & 1,5 & 1,61 & 1,64 & 1,73 & 1,75 \\
\hline Opolskie & 0,86 & 0,88 & 0,86 & 0,89 & 0,91 & 0,92 & 0,89 \\
\hline Podkarpackie & 0,71 & 0,71 & 0,71 & 0,75 & 0,78 & 0,59 & 0,59 \\
\hline Podlaskie & 0,65 & 0,65 & 0,66 & 0,68 & 0,7 & 0,74 & 0,74 \\
\hline Pomorskie & 1,27 & 1,25 & 1,25 & 1,27 & 1,34 & 1,35 & 1,41 \\
\hline Śláskie & 1,06 & 1,05 & 1,07 & 1,06 & 1,13 & 1,1 & 1,08 \\
\hline Świętokrzyskie & 0,6 & 0,59 & 0,59 & 0,62 & 0,63 & 0,61 & 0,6 \\
\hline Warmińsko-mazurskie & 0,93 & 0,92 & 0,91 & 0,95 & 0,99 & 0,95 & 0,95 \\
\hline Wielkopolskie & 0,78 & 0,8 & 0,81 & 0,83 & 0,87 & 0,87 & 0,87 \\
\hline Zachodniopomorskie & 1,33 & 1,33 & 1,31 & 1,35 & 1,49 & 1,44 & 1,42 \\
\hline
\end{tabular}

Źródło: obliczenia własne na podstawie Banku Danych Lokalnych.

Wartość wskaźnika powyżej jedynki świadczy o dominacji sektora usług nad pozostałymi sektorami, co ma miejsce w przypadku województwa: mazowieckiego (dla roku 2011 jest to 1,75 ), zachodniopomorskiego $(1,42)$, pomorskiego $(1,41)$, dolnośląskiego $(1,23)$ i lubuskiego $(1,07)$. Korzystając ze wskaźnika podaży usług, wyznaczono jego wartości dla poszczególnych województw w latach 2005-2011. O dobrym poziomie rozwoju sektora usług świadczy fakt, że w większości województw w roku 2011 w porównaniu z 2005 r. obserwujemy wzrost wartości wskaźnika podaży usług. Niepokojąca sytuacja występuje jednak w przypadku województwa podkarpackiego, lubelskiego i świętokrzyskiego. Zwróćmy jeszcze uwagę na wskaźnik nasycenia firmami usługowymi tab. 3.35. 
Tablica 3.35. Wskaźnik nasycenia firmami usługowymi

\begin{tabular}{|l|c|c|c|c|c|c|}
\hline \multicolumn{1}{c|}{$\begin{array}{c}\text { Nazwa } \\
\text { województwa }\end{array}$} & 2005 & 2006 & 2007 & 2008 & 2009 & 2010 \\
\hline Dolnośląskie & 12,07 & 12,04 & 11,89 & 11,63 & 11,63 & 11,15 \\
\hline Kujawsko-pomorskie & 14,30 & 14,35 & 14,31 & 14,11 & 14,94 & 14,67 \\
\hline Lubelskie & 18,47 & 18,28 & 18,22 & 17,93 & 17,79 & 17,00 \\
\hline Lubuskie & 12,53 & 12,19 & 12,22 & 12,89 & 13,05 & 12,53 \\
\hline Łódzkie & 13,81 & 14,22 & 14,25 & 14,18 & 15,51 & 14,77 \\
\hline Małopolskie & 14,95 & 15,00 & 14,92 & 14,68 & 14,13 & 13,48 \\
\hline Mazowieckie & 11,01 & 10,87 & 10,61 & 10,28 & 10,27 & 9,79 \\
\hline Opolskie & 15,20 & 14,81 & 14,55 & 14,44 & 14,59 & 14,09 \\
\hline Podkarpackie & 19,56 & 19,36 & 19,26 & 19,13 & 19,12 & 18,32 \\
\hline Podlaskie & 17,69 & 17,65 & 17,79 & 17,62 & 17,73 & 17,31 \\
\hline Pomorskie & 12,94 & 12,94 & 12,88 & 12,57 & 12,13 & 11,60 \\
\hline Śląskie & 57,62 & 13,97 & 13,93 & 13,92 & 13,86 & 13,26 \\
\hline Świętokrzyskie & 15,80 & 15,50 & 15,45 & 15,33 & 15,81 & 15,42 \\
\hline Warmińsko-mazurskie & 16,76 & 16,66 & 16,56 & 16,36 & 16,53 & 15,99 \\
\hline Wielkopolskie & 13,39 & 13,27 & 13,17 & 12,96 & 13,01 & 12,50 \\
\hline Zachodniopomorskie & 10,46 & 10,39 & 10,43 & 10,37 & 10,31 & 10,08 \\
\hline
\end{tabular}

Źródło: obliczenia własne na podstawie Banku Danych Lokalnych.

Analizując wartości wskaźnika nasycenia usługami określającego dostępność usług dla mieszkańców danego województwa, należy stwierdzić, że w całym analizowanym okresie najlepszą sytuacją charakteryzują się województwa: mazowieckie (ok. 10 osób na jeden punkt usługowy), zachodniopomorskie (również ok. 10 osób) i dolnośląskie (ok. 12 osób). Znacznie gorsza sytuacja występuje w województwach: podkarpackim (19 osób na jeden punkt usługowy), lubelskim (18 osób), podlaskim (ok. 17 osób) i warmińsko- mazurskim (ok. 16 osób). Otrzymane informacje pozwalają także stwierdzić, iż z roku na rok dostępność usług dla mieszkańców poszczególnych województw ulega niewielkiej poprawie. Otrzymane wskaźniki świadczą o dużym zróżnicowaniu w dostępności usług w poszczególnych województwach.

Przejdźmy teraz do oceny podobieństwa pomiędzy badanymi województwami, wykorzystując skalowanie wielowymiarowe.

Obliczono odległości euklidesowe między badanymi województwami dla dziewięciu wcześniej uwzględnionych zmiennych. Na ich podstawie dokonano 2-wymiarowe skalowanie przedstawione na rys. 3.8. Uzyskano współczynnik stresu równy 0,195 . 


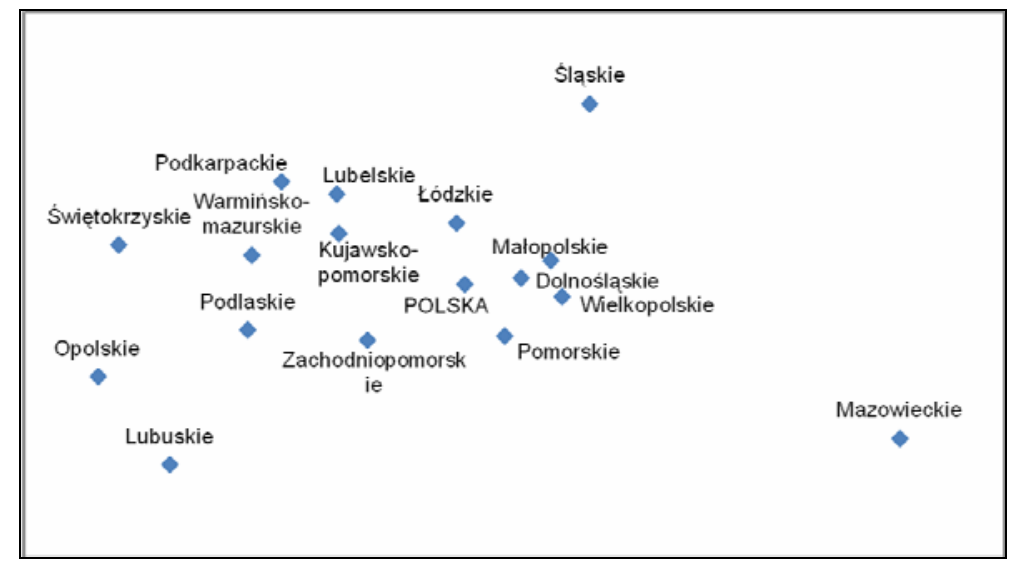

Rys. 3.8. Dwuwymiarowa konfiguracja przestrzenna województw pod względem ich podobieństwa oparta na odległościach euklidesowych

Źródło: opracowanie własne.

Możemy zauważyć duże podobieństwa pomiędzy województwem małopolskim, dolnośląskim i wielkopolskim. Mapa potwierdza często spotykaną opinię na temat rozwoju sektora usług w województwie śląskim i mazowieckim. Obliczono także odległości według metryki miejskiej między badanymi województwami dla dziewięciu wybranych zmiennych. Na ich podstawie dokonano 2-wymiarowe skalowanie. Uzyskano współczynnik stresu równy 0,103.

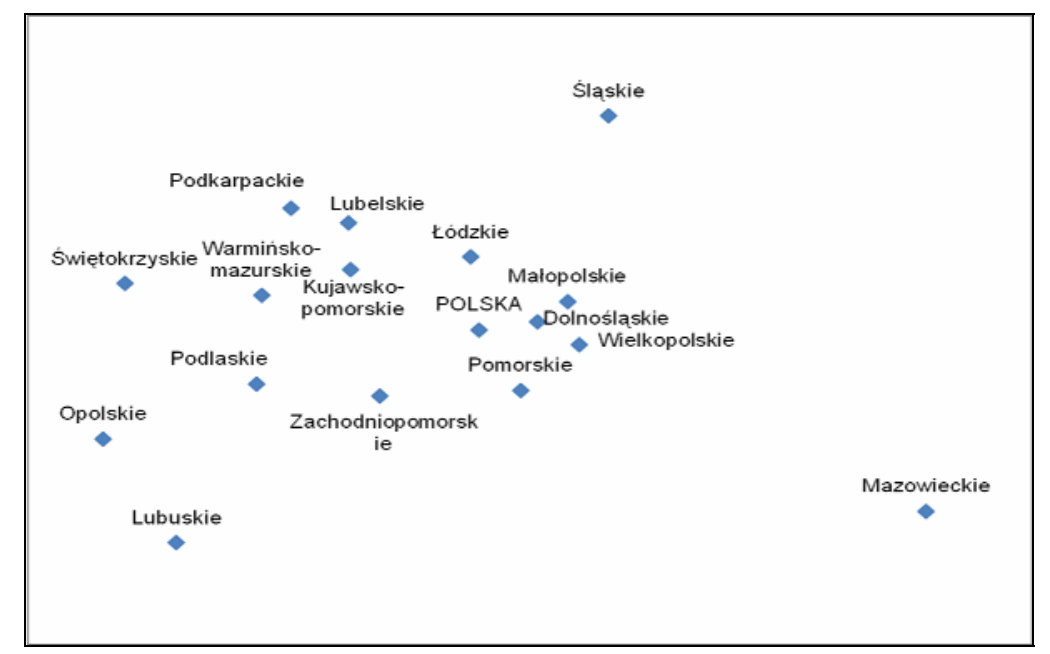

Rys. 3.9. Dwuwymiarowa konfiguracja przestrzenna województw pod względem ich podobieństwa oparta na odległościach miejskich

Źródło: opracowanie własne. 
Porównując rys. 3.8 i 3.9, zauważono, że mimo użycia innej metryki wyniki są zbliżone.

W celu dokonania oceny poziomu rozwoju sektora usług poprzez uszeregowanie i pogrupowanie województw ze względu na poziom rozwoju posłużono się miarą Hellwiga i Perkala. Zastosowanie wymienionych miar umożliwiło porównanie otrzymanych wyników. Działanie takie pozwoliło na pokazanie zróżnicowania rozwoju sektora usług w badanych województwach. Oceny rozwoju dokonano na podstawie danych za 2010 r. Wykorzystując taksonomiczne miary rozwoju, dokonano klasyfikacji województw według poziomu rozwoju sektora usług. Zostały wyodrębnione następujące przedziały klasowe (Pomianek 2010):

- klasa A (wysoki poziom rozwoju) $d_{i}>\bar{d}_{i}+s_{d_{i}}$ (do klasy należą województwa, dla których odległość od wzorca przekracza wartość $\bar{d}_{i}+s_{d_{i}}$ ),

- klasa B (średni poziom rozwoju) $\bar{d}_{i}-s_{d_{i}}<d_{i} \leq \bar{d}_{i}+s_{d_{i}}$ (do klasy należą województwa, dla których odległość od wzorca zawiera się $\mathrm{w}$ przedziale $\left.\left(\bar{d}_{i}-s_{d_{i}}, \bar{d}_{i}-s_{d_{i}}\right]\right)$,

- klasa C (niski poziom rozwoju) $d_{i} \leq \bar{d}_{i}-s_{d_{i}}$ (do klasy należą województwa, dla których odległość od wzorca przekracza wartość $\bar{d}_{i}-s_{d_{i}}$ ), gdzie:

$d_{i}$-wartość miernika syntetycznego obliczonego metodą wzorca rozwoju Hellwiga,

$\bar{d}_{i}-$ średnia arytmetyczna cechy (wskaźnika syntetycznego) $d_{i}$,

$s_{d_{i}}$ - odchylenie standardowe cechy $d_{i}$.

Metoda rozwoju Hellwiga na podstawie obliczonych taksonomicznych wskaźników rozwoju pozwala na ustalenie rankingu województw Polski według stopnia ich rozwoju. Na uporządkowanie województw pozwalają wyznaczone wartości wskaźników rozwoju $d_{i}$, które przyjmują wartości z przedziału 0-1. Miara rozwoju województw została obliczona jako syntetyczny wskaźnik taksonomicznej „odległości” danego województwa od teoretycznego wzorca rozwoju, tzn. województwa najwyżej rozwiniętego. Wyższa wartość miernika oznacza, że badane województwo znajduje się bliżej wzorca. Województwo odznacza się tym wyższym poziomem rozwoju, im wyższą wartość przyjmuje miernik $d_{i}$. Ze względu na brak możliwości porównania wartości wskaźników otrzymanych obu metodami porównywano pozycje, jakie uzyskały poszczególne województwa. Poziom zbieżności porządkowania pomiędzy metodą Hellwiga i Perkala określono za pomocą współczynnika korelacji, który wynosi 0,67 . Otrzymana wartość świadczy o umiarkowanej zbieżności wyników porządkowania województw przy wykorzystaniu obu metod. 
Tablica 3.36. Współczynniki Hellwiga i Perkala według województw

\begin{tabular}{|l|c|c|c|c|}
\hline \multicolumn{1}{|c|}{$\begin{array}{c}\text { Nazwa } \\
\text { województwa }\end{array}$} & $\begin{array}{c}\text { Współczynnik } \\
\text { Hellwiga }\end{array}$ & Ranga $\left(d_{i}\right)$ & $\begin{array}{c}\text { Współczynnik } \\
\text { Perkala }\end{array}$ & Ranga $\left(P_{i}\right)$ \\
\hline Śląskie & 0,18 & 1 & 0,22 & 2 \\
\hline Dolnośląskie & 0,17 & 2 & 0,11 & 6 \\
\hline Świętokrzyskie & 0,14 & 3 & 0,33 & 1 \\
\hline Zachodniopomorskie & 0,13 & 4 & 0,05 & 8 \\
\hline Warmińsko-mazurskie & 0,13 & 5 & 0,06 & 7 \\
\hline Kujawsko-pomorskie & 0,12 & 6 & $-0,01$ & 10 \\
\hline Lódzkie & 0,12 & 7 & 0,04 & 9 \\
\hline Pomorskie & 0,09 & 8 & $-0,22$ & 14 \\
\hline Lubuskie & 0,09 & 9 & 0,21 & 3 \\
\hline Opolskie & 0,08 & 10 & 0,20 & 4 \\
\hline Podlaskie & 0,07 & 11 & $-0,08$ & 11 \\
\hline Mazowieckie & 0,06 & 12 & 0,17 & 5 \\
\hline Wielkopolskie & 0,05 & 13 & $-0,32$ & 15 \\
\hline Lubelskie & 0,04 & 14 & $-0,22$ & 13 \\
\hline Podkarpackie & 0,04 & 15 & $-0,20$ & 12 \\
\hline Małopolskie & 0,03 & 16 & $-0,37$ & 16 \\
\hline Średnia & 0,0963 & $\times$ & $-0,0019$ & $\times$ \\
\hline Odchylenie standardowe & 0,0469 & $\times$ & 0,2118 & $\times$ \\
\hline
\end{tabular}

Źródło: opracowanie własne.

Graficzną ilustrację pozycji województw przedstawia rys. 3.10.

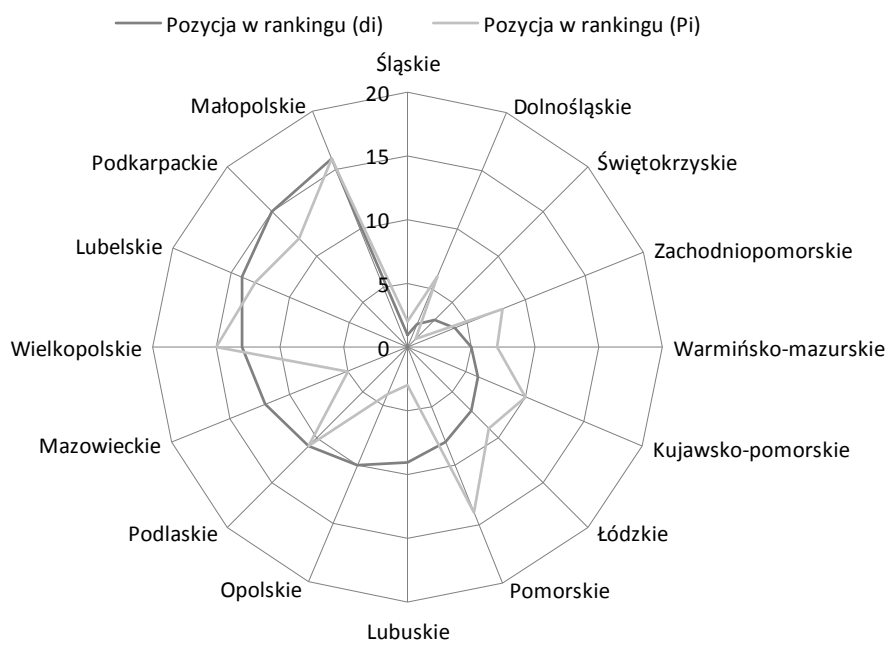

Źródło: opracowanie własne.

Rys. 3.10. Pozycje województw 
Rezultaty porządkowania województw przy wykorzystaniu obu metod wykazały, że na czołowej pozycji znajduje się województwo śląskie. Na ostatnim miejscu w przypadku zastosowania obu metod znajduje się województwo małopolskie. Na podstawie otrzymanych wskaźników Hellwiga dokonano klasyfikacji województw ze względu na poziom rozwoju sektora usług w $2010 \mathrm{r}$.

Tablica 3.37. Przynależność województw do klasy rozwoju według miary Hellwiga

\begin{tabular}{|c|l|l|}
\hline Klasa & $\begin{array}{c}\text { Kryterium przyna- } \\
\text { leżności do klasy }\end{array}$ & \multicolumn{1}{c|}{ Przynależność województwa } \\
\hline $\mathrm{A}$ & $d_{i}>0,1432$ & Śląskie, dolnośląskie \\
\hline $\mathrm{B}$ & $0,0494<d_{i} \leq 0,1432$ & $\begin{array}{l}\text { Świętokrzyskie, zachodniopomorskie, warmińsko-mazurskie, } \\
\text { kujawsko-pomorskie, tódzkie, pomorskie, lubuskie, opolskie, } \\
\text { podlaskie, mazowieckie, wielkopolskie }\end{array}$ \\
\hline $\mathrm{C}$ & $d_{i}<0,0494$ & Lubelskie, podkarpackie, małopolskie \\
\hline
\end{tabular}

Źródło: opracowanie własne.

Tablica 3.38. Przynależność województw do klasy rozwoju według miary Perkala

\begin{tabular}{|c|c|l|}
\hline Klasa & $\begin{array}{c}|c| \\
\text { Kryterium } \\
\text { przynależności } \\
\text { do klasy }\end{array}$ & \multicolumn{1}{|c|}{ Przynależność województwa } \\
\hline $\mathrm{A}$ & $P_{i}>0,2099$ & Świętokrzyskie, śląskie, lubuskie \\
\hline $\mathrm{B}$ & $-0,2137<P_{i} \leq 0,2099$ & $\begin{array}{l}\text { Dolnośląskie, zachodniopomorskie, warmińsko-mazurskie, } \\
\text { kujawsko-pomorskie, łódzkie, opolskie, podlaskie, mazowieckie, } \\
\text { podkarpackie }\end{array}$ \\
\hline $\mathrm{C}$ & $P_{i}<-, 02137$ & Pomorskie, wielkopolskie, lubelskie, małopolskie \\
\hline
\end{tabular}

Źródło: opracowanie własne.

W przedstawionym rankingu województw (tab. 3.36) uzyskanym za pomocą taksonomicznej miary rozwoju Hellwiga obliczonej na podstawie wszystkich zmiennych charakteryzujących rozwój sektora usługowego województw czołowe miejsca zajęły województwa śląskie, dolnośląskie oraz świętokrzyskie, dla których wartość syntetycznego wskaźnika rozwoju wynosiła odpowiednio: 0,18 , 0,17 i 0,14 . Ostatnie miejsce w rankingu zajęło województwo małopolskie, dla którego wartość wskaźnika wyniosła 0,03 . Wartość średnia wskaźnika dla 16 województw wyniosła 0,0963 , a odchylenie standardowe 0,0469 . W celu zbadania zależności pomiędzy obliczonymi miarami wyznaczono współczynnik korelacji $(0,81)$, który świadczy o dość wysokiej zależności. Niemniej jednak pomimo dość dużego podobieństwa, na które wskazuje otrzymany wynik, widoczne są pewne różnice $\mathrm{w}$ uzyskiwanych miejscach $\mathrm{w}$ rankingu, wyznaczonych za pomocą dwu metod. Różnice te są znaczące w przypadku województw: lubu- 
skiego, pomorskiego, opolskiego i mazowieckiego. W przypadku pozostałych województw różnice w uzyskanej pozycji nie są aż tak duże.

W wyniku zastosowania obu metod zostały wskazane województwa o wysokim poziomie rozwoju oraz województwa charakteryzujące się niskim poziomem rozwoju sektora usługowego. Z przeprowadzonej analizy wynika, że większość województw cechuje przeciętny poziom rozwoju sektora usług.

W Polsce proces rozwoju usług ze względu na uwarunkowania polityczne rozpoczął się znacznie później niż w państwach Europy Zachodniej. Zarówno rzemiosło, jak i drobny handel należały do prywatnych przedsiębiorców i nie były popierane przez państwa socjalistyczne Poza tym głębokie przekonanie, że tylko przemysł jest sektorem gospodarki wpływającym na rozwój gospodarczy kraju, wywarło duży wpływ na przestrzenne zróżnicowanie usług. Biorąc pod uwagę w każdym $\mathrm{z}$ województw udział pracujących, udział podmiotów gospodarczych, udział wartości dodanej brutto w 2010 r. oraz zmiany tych wskaźników w stosunku do roku 2005 najwyższą aktywność w rozwoju sektora usług osiagnęły województwa: mazowieckie, zachodniopomorskie, pomorskie, dolnośląskie i śląskie. Natomiast do sekcji usługowych, mających największy wpływ na rozwój społeczno-gospodarczy, należy zaliczyć: handel i naprawy, obsługę rynku nieruchomości oraz transport i gospodarkę magazynową. Silny niedorozwój usług obserwujemy na obszarach wiejskich, terenach województw, gdzie przeważa działalność typowo rolnicza. Do obszarów zaniedbanych usługowo zaliczamy wschodnią, północno-wschodnia i południowo-wschodnią cześć kraju. Poziom rozwoju poszczególnych rodzajów usług jest uwarunkowany nie tylko rozwojem ekonomicznym, ale także charakterem gospodarczym danego województwa. Inny rodzaj usług dominuje w województwach wysoko uprzemysłowionych, inny w regionach turystycznych, a jeszcze inny tam, gdzie nadal dominuje sektor rolniczy.

Podsumowując wyniki przeprowadzonej analizy opartej na danych statystycznych, należy zastanowić się nad czynnikami, które mogą wpłynąć na dalszy rozwój sektora usług w poszczególnych województwach. Do czynników sprzyjających rozwojowi sektora usług można zaliczyć:

- współpracę władz samorządu terytorialnego z podmiotami usługowymi poprzez zapewnienie ze strony samorządów dogodnych warunków inwestycyjnych zarówno inwestorom krajowym, jak i zagranicznym (np. dogodna lokalizacja, ulgi podatkowe). Prowadzenie inwestycji na danym terenie stwarza nowe miejsca pracy, daje szanse na dodatkowe zarobki oraz wpływa na rozwój gospodarczy danego regionu;

- dążenie do zagospodarowania nadmiaru siły roboczej na terenach wiejskich poprzez stworzenie warunków rozwoju sektora usług na tych terenach; 
- wspieranie rozwoju ośrodków prowadzących działalność naukowo-badawczą oraz szeroko rozumiana współpraca samorządów terytorialnych $\mathrm{z}$ ośrodkami naukowymi;

- pozyskiwanie środków unijnych, w celu podnoszenia kwalifikacji i stworzenia możliwości przekwalifikowania poszukujących pracy oraz bezrobotnych;

- dążenie do wprowadzania nowoczesnych technologii i innowacji.

Rola usług w gospodarce głównie zależy od udziału sektora usług w generowaniu wartości dodanej brutto oraz poziomu zatrudnienia. Sektor usług wpływa na prawidłowe funkcjonowania całej gospodarki.

\subsection{Rozwój sektora usług w Polsce i innych krajach Unii Europejskiej}

Unia Europejska została utworzona na mocy traktatu z Maastricht, który wszedł w życie w 1993 r. Polska uzyskała członkostwo w Unii Europejskiej 1 maja 2004 r. wraz z nią Czechy, Węgry, Estonia, Słowacja, Słowenia, Cypr, Litwa, Łotwa i Malta. W 2007 r. do grona państw UE dołączyły Bułgaria i Rumunia. Państwa członkowskie po wstąpieniu do UE liczą na większe bezpieczeństwo, wyższą stabilność gospodarczą, stały wzrost gospodarczy, a przede wszystkim na wyrównanie poziomu rozwoju społeczno-gospodarczego. Stymulowanie wzrostu gospodarczego poprzez pobudzanie do działania w sektorze usług ma miejsce we wszystkich rozwijających się gospodarkach. Państwa Unii Europejskiej charakteryzują się wysokim stopniem rozwoju sektora usług, choć dynamika rozwoju poszczególnych rodzajów działalności usługowych w różnych krajach jest odmienna. Za jedną z przyczyn dużego zróżnicowania w rozwoju poszczególnych państw uznaje się postęp technologiczny. Wśród wielu mierników rozwoju regionalnego uwagę zwraca wskaźnik stanu społeczeństwa informacyjnego, którego głównymi elementami są gospodarka oparta na wiedzy oraz stopień wykorzystania i dostępności technologii informacyjnej i telekomunikacji (Kurek 2010).

Celem rozważań $\mathrm{w}$ tej części pracy jest wskazanie pewnych podobieństw i różnic w rozwoju sektora usług państw Unii Europejskiej. Porównanie poszczególnych państw UE pod względem udziału sektora usług w tworzeniu wartości dodanej brutto oraz udziału pracujących w usługach w ogólnej liczbie pracujących pozwala ocenić, które gospodarki są bardziej zaawansowane w rozwoju sektora usług i jaki dystans dzieli poszczególne państwa. W tab. 3.39 przedstawiono dane dotyczące struktury wartości dodanej brutto oraz pracujących według sektorów gospodarki w państwach UE-27 oraz w Polsce. 
Tablica 3. 39. Struktura wartości dodanej brutto i pracujący według sektorów gospodarki w Polsce na tle państw UE, w $2009 \mathrm{r}$.

\begin{tabular}{|l|c|c|c|c|}
\hline \multirow{2}{*}{ Wyszczególnienie } & \multicolumn{2}{|c|}{ Wartość dodana brutto (w \%) } & \multicolumn{2}{c|}{ Pracujący (w \%) } \\
\cline { 2 - 5 } & UE-27 & Polska & UE-27 & Polska \\
\hline Sektor rolny & 1,6 & 3,6 & 5,5 & 13,9 \\
\hline Sektor przemysłowy & 24,3 & 31,8 & 24,0 & 31,5 \\
\hline Sektor usługowy & 74,1 & 64,6 & 70,5 & 54,6 \\
\hline
\end{tabular}

Źródło: Raport, Usługi w Polsce 2008-2010, IBR, KiK.

Porównując udział sektora usług w generowaniu wartość dodanej brutto oraz pracujących, obserwujemy wyraźny dystans dzielący Polskę od państw UE. Przyczyna silnego zróżnicowania sektorowej struktury gospodarki polskiej i gospodarek państw wysoko rozwiniętych między innymi tkwi w sektorze rolnym. Polska wstępując do Unii w 2004 r. miała jeden z najwyższych odsetków pracujących w rolnictwie $(18,0 \%)$, podczas gdy w Unii wartość ta była o ponad połowę mniejsza. Polskie rolnictwo charakteryzuje się wysokim poziomem rozdrobnienia i niską produktywnością. Struktura rozdrobnionych gospodarstw rolnych w Polsce, o średniej powierzchni gruntów rolnych 10,38 ha w $2012 \mathrm{r}$. (według ARiMR), jest znacznie mniejsza niż w innych krajach Unii, co sprawia, że Polska jest krajem mało konkurencyjnym. Ponad połowa polskich gospodarstw zajmuje powierzchnię około 5 ha, produkując plony na użytek własny. Widoczny jest jednak proces deagraryzacji, polegający na zmniejszającej się roli rolnictwa w generowaniu wartości dodanej brutto i poziomie zatrudnienia. Przyczyna dystansu tkwi także w niskim uprzemysłowieniu wielu regionów w Polsce oraz niższej wydajności pracy. Powodem słabego tempa wzrostu wydajności pracy mogą być niskie inwestycje. Niska produktywność przemysłu może być także spowodowana niskim zatrudnieniem w usługach biznesowych. Istnienie różnic w poziomie rozwoju gospodarczego Polski i państw Unii Europejskiej powoduje, że nasza gospodarka jest mało konkurencyjna i niedostatecznie dostrzegana na europejskim rynku. Ilustrację graficzną struktury wartości dodanej brutto według rodzajów działalności w państwach Unii Europejskiej w 2010 r. przedstawia rys. 3.11.

W porównaniach trójsektorowych (por. tab. 3.40) na uwagę zasługuje sektor rolny, wysoki udział pracujących $\mathrm{w}$ tym sektorze ze względu na niski poziom kwalifikacji stanowi poważny problem, dotyczy to także Polski. Szansą dla sektora rolnego jest przepływ siły roboczej do sektora usług, wymaga to jednak głębokich zmian zarówno w świadomości, jak i kwalifikacjach. Najwyższy udział wartości dodanej brutto sektora rolnego w 2000 r. odnotowano w Bułgarii - 13,9\%, ale w roku 2008 (po wstąpieniu w 2007 r. do UE) było to $6,9 \%$, zaś w 2011 r. 5,6\%. 


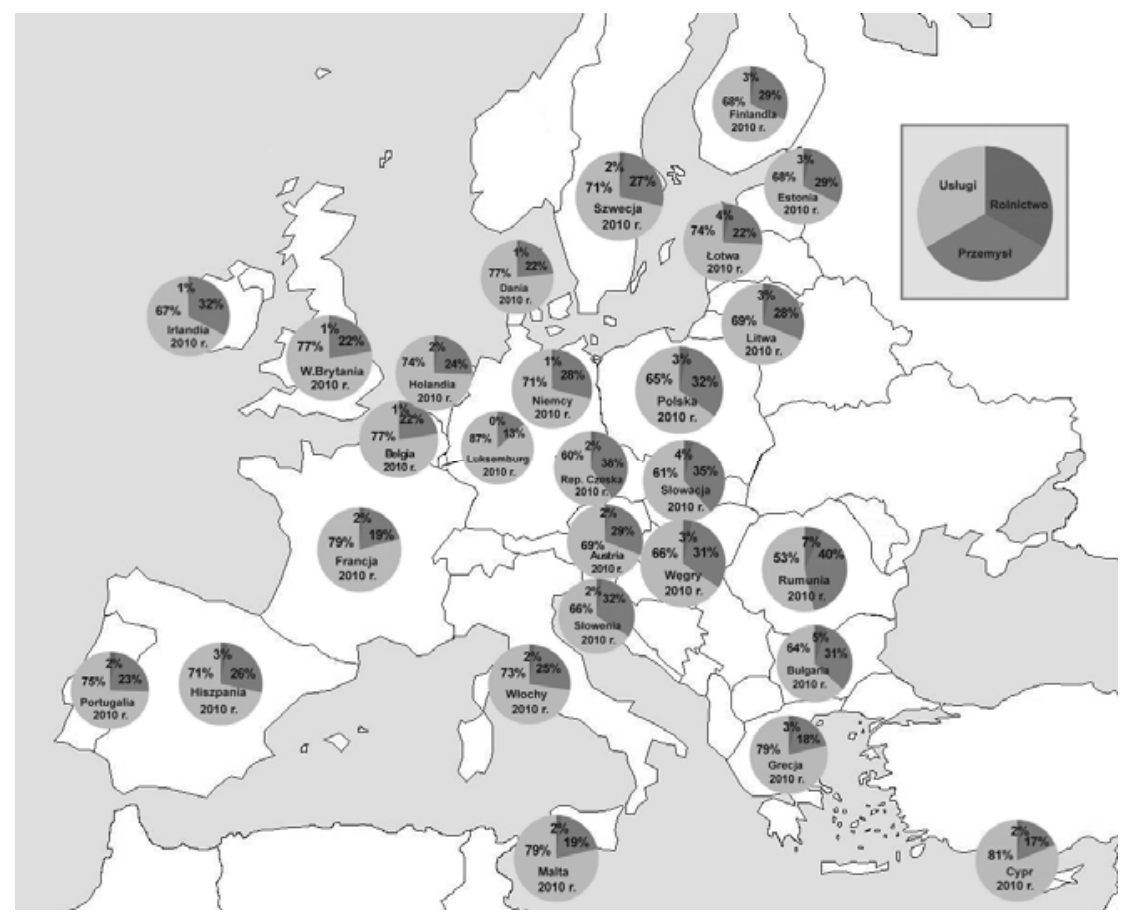

Rys. 3.11. Struktura wartości dodanej brutto według rodzajów działalności w UE w 2010 r. Źródło: opracowanie własne.

Podobnie w Rumunii w 2000 r. udział wyniósł 12,1\%, w 2008 r. 7,4\%, podobnie w 2011 r. Udział wartości dodanej w przemyśle w Irlandii w 2000 r. przekraczał 40\%, a w 2008 r. osiagnął poziom 31,5\% (podobnie jak Bułgaria).

Zdecydowanie $w$ gospodarkach wszystkich państw UE najwyższym udziałem wartości dodanej brutto charakteryzuje się sektor usług. W 2004 r. w Unii Europejskiej (25 państw członkowskich) wartość dodana wytworzona w sektorze usług stanowiła 71,3\% wartości dodanej całej gospodarki (Rynek wewnętrzny w 2005 r.). W 2004 r. najwyższy udział $\mathrm{w}$ tworzeniu wartości dodanej brutto w sektorze usług osiagnął Luksemburg - 82,2\% oraz Cypr - 77,3\%. W 2004 r. do Unii przyjęto 10 nowych państw, były to: Cypr, Czechy, Estonia, Litwa, Łotwa, Malta, Polska, Słowacja, Słowenia i Wegry. Dwa lata później w 2006 r. czesść nowo przyjętych państw wykazała wysoki udział w tworzeniu wartości dodanej brutto $\mathrm{w}$ sektorze usług, były to: Łotwa - 74,9\%, Estonia - 67,7\% i Węgry - 65\% (Rynek Wewnętrzny w 2007). W styczniu 2007 r. do Unii Europejskiej zostały przyjęte Bułgaria i Rumunia W roku 2008 najwyższy udział wartości dodanej wykazały: Luksemburg - 85,2\%, Cypr - 79,2\%, Grecja 78,7\%. Podobnie kształtował się udział wartości dodanej brutto w 2009 r., także dominował Luksemburg - 85,7\%, Grecja - 79,9\% i Francja - 79,5\%. 


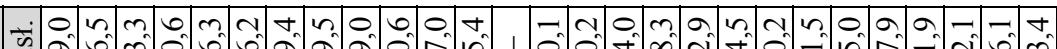

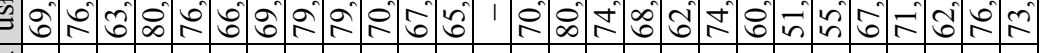
d)

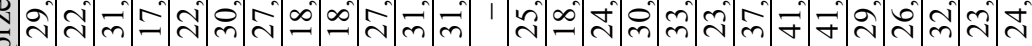
jं 어

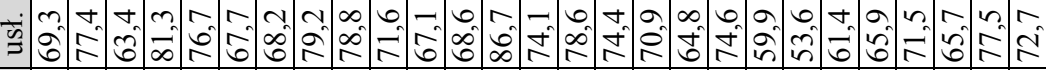

응 ㄱa m t

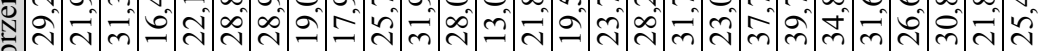
бं

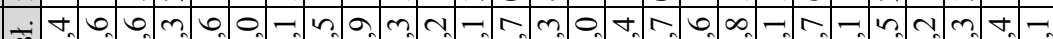

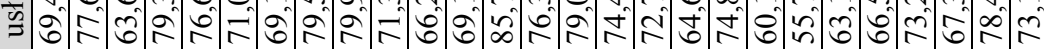

8

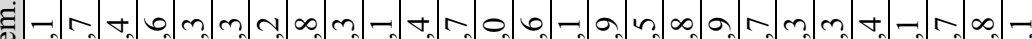
N N - $\ln$ N 官

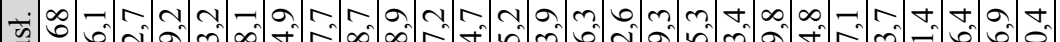

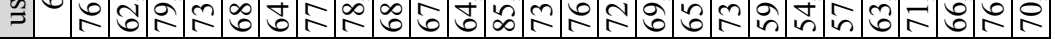
घ다.

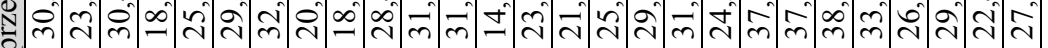

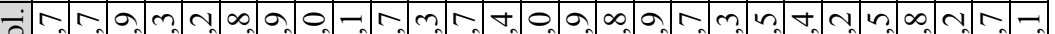
: 0 0

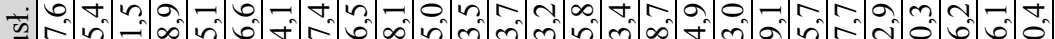

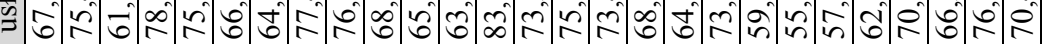

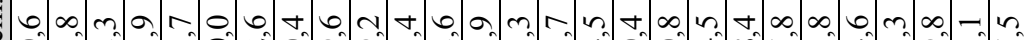

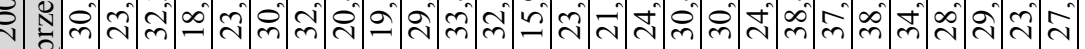

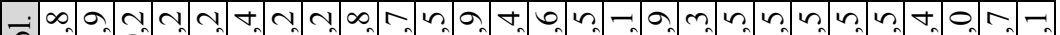

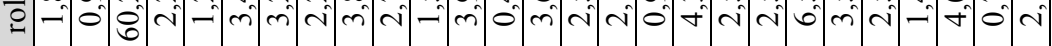
$\rightarrow \infty \tau_{0}$ m

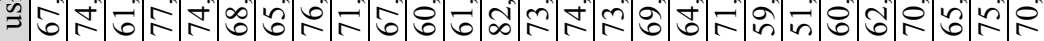

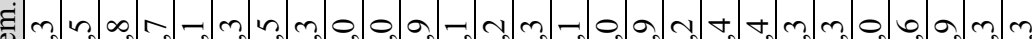
అ

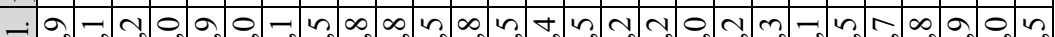

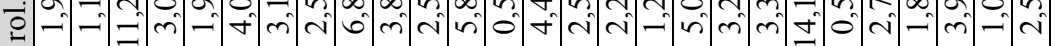

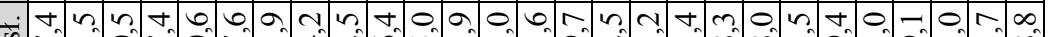

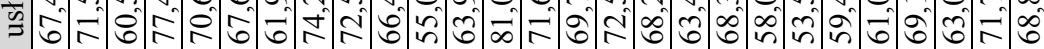

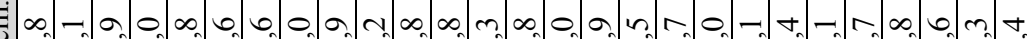
ᄀ N - 0 t गु व

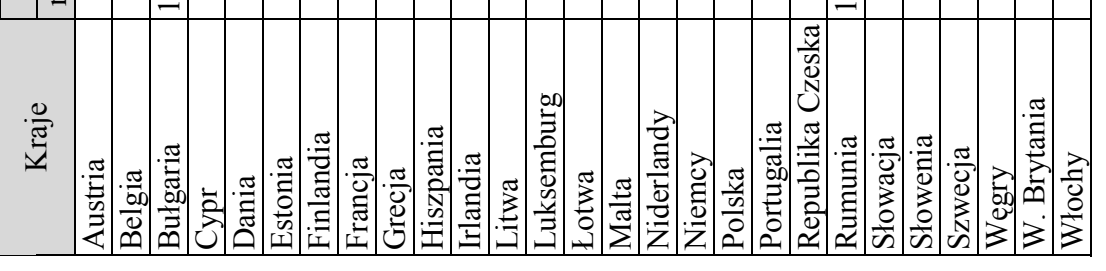


Najwyższy wzrost udziału sektora usług w tworzeniu wartości dodanej w porównaniu z rokiem 2000 wykazała Irlandia - o 12,2\%. Niższe udziały sektora usług w tworzeniu wartości dodanej brutto niż w Polsce w 2008 r. miało siedem spośród porównywanych państw: Bułgaria $(62,7)$, Finlandia $(64,9)$, Litwa $(64,7)$, Słowenia $(63,7)$, Czechy $(59,8)$, Rumunia $(54,8)$ i Słowacja $(57,1)$. $\mathrm{W}$ przeważającej mierze są to państwa o bardzo wysokim udziale rolnictwa w generowaniu wartości dodanej brutto. W roku 2011 wśród państw członkowskich Unii Europejskiej najwyższy udział wartości dodanej wytworzonej przez sektor usług miał miejsce na Cyprze - 80,6\%, Malcie - 80,2\% oraz we Francji $79,5 \%$. Znaczny udział wartości dodanej w sektorze usług zaobserwowano także w Wielkiej Brytanii - 76,1\%, Włoszech - 73,4\%, Hiszpanii - 70,6\% oraz Niemczech $-68,3 \%$. Spadek udziału sektora usług w tworzeniu wartości dodanej brutto nastapił w Słowacji (0-4,3 p.p.), Rumunii (0-2,0 p.p.) i w Niemczech (0-0,1 p.p.) (Rynek wewnętrzny 2012).

Oprócz zmian w strukturze wartości dodanej zachodzą także zmiany w strukturze pracujących. Celem państw Unii Europejskiej oraz Rady Europy jest prowadzenie polityki zatrudnienia opartej na walce $\mathrm{z}$ bezrobociem, dążenie do poprawy kwalifikacji siły roboczej oraz dostosowywanie się do zmieniających się warunków na rynku pracy. Według danych GUS (dane w „Przeglądzie Międzynarodowym” dla Polski różnią się od danych podawanych w części krajowej Roczników) w 2010 r. wskaźnik zatrudnienia w Unii Europejskiej wyniósł przeciętnie $64,1 \%$, w tym dla Polski $-59,3 \%$. W Unii przeciętnie w roku 2010 pracowało $212,4 \mathrm{mln}$ osób, w tym $96,6 \mathrm{mln}$ to kobiety. Dla porównania w roku 2000 przeciętnie pracowało 186,4 mln osób, w tym 80,4 mln to kobiety; w roku 2005 liczba pracujących w Unii wzrosła do 194,6 mln, w tym kobiety pracujące to $86,1 \mathrm{mln}$. W tym w Polsce w roku 2010 pracowało $15,7 \mathrm{mln}$, a 7,1 $\mathrm{mln}$ to kobiety. W 2000 r. w Polsce pracowało przeciętnie 14,2 mln osób, w tym 6,4 mln kobiet, zaś w 2005 r., czyli w rok po przystapieniu do Unii liczba pracujących spadła do 13,8 mln osób, w tym liczba pracujących kobiet wynosiła 6,2\%.

W 2010 r. w sektorze rolnictwo, łowiectwo i leśnictwo oraz rybactwo w Unii pracowało 5,4\%, w tym w Polsce 12,7\%. W roku 2000 i 2005 w sektorze rolnym w Unii Europejskiej także pracowało około 5\%. W Polsce wartości te wynosiły odpowiednio $26,3 \%$ i 19,2\%. W przemyśle i budownictwie w $2010 \mathrm{r}$. w UE pracowało $23,3 \%$, w tym w Polsce 30,0\%. Analogicznie w roku 2000 i 2005 wartości te wynosiły $26,6 \%$ i $25 \%$, w tym dla Polski $27,2 \%$ w 2000 r. i $26,9 \%$ w $2005 \mathrm{r}$.

W sektorze usług w Unii pracowało w 2010 r. 71,4\%, w tym w Polsce $57,3 \%$. W 2000 r. odsetek pracujących w UE w usługach wyniósł $68 \%$, a w 2005 r. wzrósł do $70 \%$, w tym dla Polski odsetek ten wynosił $46,5 \%$ dla roku 2000 i 53,9\% w roku 2005 . W miarę rozwoju sektora usług następują także zmiany wewnątrz samego sektora w liczbie pracujących. Wzrasta udział pośred- 
nictwa finansowego oraz obsługi nieruchomości i firm kosztem handlu i napraw, hoteli i restauracji oraz transportu, gospodarki magazynowej i łączności. Według Raportu Ministerstwa Gospodarki (2010) w najbardziej rozwiniętych państwach udział pracujących $\mathrm{w}$ pośrednictwie finansowym oraz obsłudze nieruchomości i firm w liczbie pracujących w sektorze usług przekracza $20 \%$. $Z$ danych Eurostatu wynika również, że od 2004 r. „kraje piętnastki” charakteryzowały się wyższa dynamiką zatrudnienia niż licząca 27 krajów Unia. Wyższą dynamikę w zatrudnieniu w państwach całej Unii obserwujemy od 2005 r., co może być związane z realizacją przez nowo przyjęte państwa inwestycji współfinansowanych ze środków unijnych. Na uwagę zasługuje także wysoka fala emigracji, jaka miała miejsce po przystapieniu Polski do Unii Europejskiej. Z Raportu Polska 2011 wynika, że liczba obywateli Polski przebywających dłużej niż 2 miesiące za granicą wzrosła w latach 2004-2007 z 1 do 2,27 mln. Po 2007 r. skala migracji nieco osłabła, osiągając w 2009 r. poziom 1,87 mln osób. Uważa się, że istotnym czynnikiem mającym wpływ na skalę migracji był kryzys światowy, który wielu Polaków skłonił do powrotu do kraju. W tab. 3.41 przedstawiono strukturę pracujących w krajach Unii Europejskiej według rodzajów działalności.

Wraz ze wzrostem zatrudnienia w sektorze usługowym następuje spadek liczby pracujących w sektorze przemysłowym i rolnym.

W Polsce obserwowalny jest proces, polegający na utrzymaniu ciągle wysokiego poziomu zatrudnienia $\mathrm{w}$ rolnictwie i spadku zatrudnienia $\mathrm{w}$ przemyśle. Sektor przemysłowy jest jednak bazą dla większości rodzajów usług. Wiele $\mathrm{z}$ nich jest związanych z przemysłem, a niektóre wręcz są od niego zależne.

Porównując Polskę z innymi państwami UE, widoczny jest wyraźny dystans zarówno w poziomie wartości dodanej brutto, jak i zatrudnienia. Spadek zatrudnienia w 1999 r. i w latach następnych doprowadził do dużej różnicy w stosunku do państw UE 15, w których obserwowano wzrost zatrudnienia i spadek bezrobocia. Polityka państw UE dąży do walki z bezrobociem, poprawy kwalifikacji siły roboczej oraz dostosowania się do zmieniającej się sytuacji na rynku pracy. Rynek pracy UE charakteryzuje się dużym, strukturalnym niedoborem popytu na pracę, zwłaszcza o niskich kwalifikacjach. Panująca obecnie sytuacja demograficzna, polegająca na starzeniu się społeczeństwa, wydłużaniu przeciętnego okresu trwania życia i niskim przyroście naturalnym wśród państw UE, powoduje, że państwa europejskie poszukują i będą poszukiwały pracowników poza swoimi granicami.

Kwiatkowski (2010) na podstawie analiz porównawczych rynku pracy w Polsce i krajach Unii Europejskiej określa najważniejsze wyzwania stojące przed polskim rynkiem pracy, do których zalicza: zwiększenie aktywności zawodowej, obniżenie stóp bezrobocia, wzrost zatrudnienia oraz zmodernizowanie sektorowej struktury zatrudnienia. W celu sprostania tym wyzwaniom konieczna 
jest poprawa mobilności siły roboczej przede wszystkim w przekroju przestrzennym, kwalifikacyjno-zawodowym i międzyzakładowym, poza tym należy zwrócić uwagę na poprawę jakości kształcenia i dostosowanie profili kształcenia do wymogów rynku pracy.

Tablica 3.41. Pracujący według rodzajów działalności

\begin{tabular}{|l|c|c|c|c|c|c|}
\hline \multirow{2}{*}{ Kraj } & \multicolumn{2}{|c|}{2000} & \multicolumn{3}{c|}{2010} \\
\cline { 2 - 7 } & $\begin{array}{c}\text { rolnictwo, } \\
\text { leśnictwo i } \\
\text { rybactwo }\end{array}$ & $\begin{array}{c}\text { przemysł } \\
\text { i budownictwo }\end{array}$ & usługi & $\begin{array}{c}\text { rolnictwo, } \\
\text { leśnictwo } \\
\text { i rybactwo }\end{array}$ & $\begin{array}{c}\text { przemysł } \\
\text { i budownictwo }\end{array}$ & usługi \\
\hline Austria & 5,8 & 30,3 & 64,0 & 5,2 & 24,9 & 69,9 \\
\hline Belgia & 1,9 & 25,8 & 72,3 & 1,4 & 23,4 & 75,3 \\
\hline Bułgaria & 13,1 & 32,7 & 53,6 & 6,8 & 33,3 & 59,9 \\
\hline Cypr & 5,2 & 23,8 & 70,9 & 3,8 & 20,8 & 75,3 \\
\hline Dania & 3,3 & 25,2 & 71,4 & 2,4 & 19,6 & 77,7 \\
\hline Estonia & 7,1 & 33,3 & 59,6 & 4,2 & 30,1 & 65,1 \\
\hline Finlandia & 6,0 & 27,2 & 66,4 & 4,4 & 23,2 & 71,9 \\
\hline Francja & 4,1 & 26,3 & 69,6 & 2,9 & 22,2 & 74,5 \\
\hline Grecja & 17,4 & 22,6 & 60,0 & 12,5 & 19,7 & 67,7 \\
\hline Hiszpania & 6,7 & 30,8 & 62,5 & 4,3 & 23,1 & 72,6 \\
\hline Irlandia & 6,5 & 27,7 & 65,4 & 4,6 & 19,5 & 75,5 \\
\hline Litwa & 18,7 & 26,8 & 54,5 & 9,0 & 24,4 & 66,2 \\
\hline Luksemburg & 2,4 & 20,7 & 76,6 & 1,0 & 12,0 & 81,1 \\
\hline Łotwa & 14,5 & 26,3 & 59,1 & 8,8 & 24,0 & 66,9 \\
\hline Malta & 1,7 & 32,3 & 65,1 & 1,3 & 24,6 & 72,9 \\
\hline Niderlandy & 3,0 & 20,2 & 70,4 & 2,8 & 15,9 & 71,6 \\
\hline Niemcy & 2,6 & 33,5 & 63,8 & 1,6 & 28,4 & 70,0 \\
\hline Polska & 18,8 & 30,8 & 50,4 & 12,9 & 30,2 & 56,9 \\
\hline Portugalia & 12,5 & 34,4 & 53,0 & 10,9 & 27,7 & 61,4 \\
\hline Republika Czeska & 5,1 & 39,5 & 55,4 & 3,1 & 38,0 & 58,9 \\
\hline Rumunia & 42,8 & 26,2 & 31,0 & 30,1 & 28,7 & 41,2 \\
\hline Słowacja & 6,7 & 37,3 & 56,1 & 3,2 & 37,1 & 59,6 \\
\hline Słowenia & 9,5 & 37,4 & 52,3 & 8,8 & 32,5 & 58,3 \\
\hline Szwecja & 2,4 & 24,5 & 73,0 & 2,1 & 19,9 & 77,7 \\
\hline Węgry & 6,5 & 33,7 & 59,7 & 4,5 & 30,7 & 64,9 \\
\hline W. Brytania & 1,5 & 25,1 & 73,1 & 1,2 & 19,1 & 78,9 \\
\hline Włochy & 5,2 & 31,8 & 63,0 & 3,8 & 28,8 & 67,5 \\
\hline
\end{tabular}

Źródło: opracowanie własne na podstawie: Rocznik Statystyki Międzynarodowej 2012, GUS. 
Porównań międzynarodowych można także dokonać wśród państw należących do OECD. Udział sektora usług w wytwarzaniu wartości dodanej brutto w państwach OECD w latach 1970-2004 był najważniejszym składnikiem gospodarki Początkowo usługi wytwarzały około 50\% wartości dodanej brutto, zwiększając swój udział do około 70\%. Podobnie wyglądała sytuacja zatrudnionych w usługach Sektor usług na początku badanego okresu zatrudniał około $50 \%$ ludności, obecnie zatrudnia powyżej $70 \%$. Udział sektora usług w zatrudnieniu oraz w wytwarzaniu wartości dodanej brutto pozwala twierdzić, że usługi są także dominującym sektorem gospodarki krajów wysoko rozwiniętych. Usługi odgrywają także coraz większą rolę w handlu zagranicznym. W latach 19952008 miał miejsce szybki rozwój wymiany międzynarodowej usług, W 2007 r. wielkość światowego eksportu usług w porównaniu z 1995 r. wzrosła o 176,6\%. Import usług w analogicznym okresie wzrósł o 155,2\%. Światowy eksport usług w 2007 r. wyniósł 3416 mld USD, a import 3205 mld USD.

Według Raportu Ministerstwa Gospodarki (2010) najszybszy wzrost eksportu usług w badanym okresie zanotowano w Wielkiej Brytanii o 194\%, Niemczech o $171 \%$, natomiast najwolniejszy wzrost eksportu nastąpił we Francji o 73\%. Warty podkreślenia jest fakt, że w krajach Europy ŚrodkowoWschodniej dynamika eksportu usług jest wyższa niż w krajach wysoko rozwiniętych. Na Węgrzech w badanym okresie eksport usług wzrósł o 226\%, na Słowacji o 197\%, w Polsce o 170\%, a w Czechach o 155\%. Uwzględniając rodzaj eksportowanych usług we wszystkich państwach, w najszybszym tempie wzrastał eksport usług komputerowo-informatycznych. W krajach rozwiniętych duży udział w eksporcie usług miały także usługi ubezpieczeniowe, finansowe oraz sprzedaż licencji. W Polsce w ogólnym eksporcie usług przeważający udział mają usługi turystyczne i transportowe, tj. 69\%. W imporcie usług podobnie jak w eksporcie najszybszy wzrost był w usługach komputerowoinformatycznych, a przodującym państwem także była Wielka Brytania. W większości państw duży udział w imporcie mają usługi transportowe i turystyczne.

Przeprowadzona analiza sektora usług pod kątem liczby pracujących oraz wartości dodanej brutto pozwala twierdzić, że sektor usług jest dominującym sektorem zarówno polskiej gospodarki, jak i państw Unii Europejskiej. W wielu analizach i publikacjach na ten temat podkreśla się, że wysoki udział wartości dodanej brutto i pracujących w usługach nie zawsze jest równoznaczny z wysokim poziomem ogólnego rozwoju gospodarczego (Fazlagić 2001). Nie wszystkie rodzaje usług w jednakowym stopniu wpływają na rozwój gospodarczy oraz nie wszystkie wyroby sektora usług charakteryzuje wysoki współczynnik elastyczności dochodowej popytu. Wzrost zatrudnienia w usługach nie zawsze oznacza wzrost konsumpcji usług. Proces wzrostu zatrudnienia w sektorze usług może być spowodowany postępem technologicznym oraz obsługą procesów wytwórczych. Na sektor usług zarówno w Polsce, jak i państwach wysoko rozwiniętych 
wpływa wiele czynników, do których możemy zaliczyć (Cyrek 2005): zmiany społeczno-demograficzne, rozwój procesów technologicznych, wydłużenie średniego okresu życia, wzrost poziomu dochodów, jakość życia. Czynniki te sprawiaja, że sektor usług podlega wewnętrznym przemianom i nie jest jeszcze ostatecznie ukształtowany. Bezsporne jest, że usługi zawdzięczają swój rozwój przemianom $\mathrm{w}$ procesach produkcyjnych zachodzących $\mathrm{w}$ sektorach przemysłowym i rolniczym. Kierunkiem dalszego rozwoju sektora usług są usługi, na które zapotrzebowanie wskazuje współczesny konsument, dla którego największe znaczenie ma informacja oraz usługi związane $\mathrm{z}$ jej przetwarzaniem, przesyłaniem i archiwizowaniem. Duże nadzieje są także wiązane z rozwojem usług biznesowych. W związku z procesem starzenia się społeczeństwa, wynikającym zarówno ze struktury demograficznej, jak i wydłużeniem czasu trwania życia, można spodziewać się intensywnego rozwoju usług o charakterze opiekuńczozdrowotnym. Coraz większego znaczenia nabierają także usługi związane z wykorzystaniem czasu wolnego i ochroną środowiska, nie bez znaczenia pozostają także usługi kierowane do osób niepełnosprawnych.

Warty podkreślenia jest też fakt, że w 1986 r. z inicjatywy Urzędu Statystycznego Kanady została powołana Grupa Voorburg do spraw statystyki sektora usług. Ze względu na wzrost znaczenia sektora usług za główny cel Grupy przyjęto identyfikowanie i definiowanie działalności usługowej, pomiar wartości, dążenie do stworzenia jednolitej metodologii badań cen producenta $\mathrm{w}$ celu lepszego pomiaru PKB oraz stworzenie wskaźnika produkcji sektora usług. O rozwoju sektora usług świadczy także potrzeba przeprowadzania badań związanych z usługami. Przeprowadzane są badania na temat: „Ocena działalności przedsiębiorstw świadczących usługi związane z obsługą działalności gospodarczej”, „Popyt na usługi”, „Międzynarodowy handel usługami” oraz „Badanie cen producentów usług”. Trwają także prace na temat „Indeks produkcji sektora usług", których celem jest opracowanie metodologii liczenia wskaźnika produkcji sektora usług dla Polski, umożliwiającego ocenę rozwoju sektora usługowego (Adach-Stankiewicz, Matulska-Bachura 2012).

Wnikliwa analiza przedstawionych danych pozwala sformułować wniosek, iż w miarę rozwoju społeczno-gospodarczego następuje wzrost znaczenia sektora usług w gospodarce.

\subsection{Uwagi końcowe}

W celu przeprowadzenia pełnego obrazu zachodzących w sektorze usług zmian badania były przeprowadzane w trzech przekrojach: kraju, regionu oraz na poziomie państw Unii Europejskiej. Potrzeba prowadzenia badań na trzech poziomach wynikała $\mathrm{z}$ dużego zróżnicowania rozwoju usług w poszczególnych 
województwach czy państwach Unii Europejskiej. W wyniku przeprowadzonych badań nasuwają się następujące wnioski:

1. W Polsce w latach 1994-2011 struktura pracujących według trzech sektorów gospodarki uległa znacznym zmianom. Obserwujemy wyraźną dominację sektora usług w poziomie zatrudnienia $(42,21 \%$ w 1994 i 56,33\% w 2011 r.) i spadek liczby pracujacych w sektorze rolnym $(27,17 \%$ w 1994 i $16,79 \%$ w 2011 r.). Zgodnie z teorią trzech sektorów analiza danych świadczy o zmniejszającej się roli sektora rolniczego i wzroście znaczenia sektora usług. Wzrost zatrudnienia w sektorze usług jest rezultatem realokacji zasobów pracy z sektora rolnego oraz z przemysłu.

2. W analizowanym okresie nastąpił wzrost udziału wartości dodanej brutto generowanej przez sektor usług (52,75\% w 1994 i 63,05\% w 2011 r.), zmniejszył się udział wartości dodanej brutto w sektorze rolnym (7,43\% w 1994 i 3,6\% w 2011 r.), spadek miał miejsce także w przemyśle $(39,82 \%$ w 1994 i 33,35\% w 2011 r.).

3. W latach 2005-2010 zaobserwowano dominujący udział podmiotów gospodarczych zarejestrowanych $\mathrm{w}$ rejestrze REGON w sektorze usług. W analizowanym okresie udział sektora rolnego wynosił około $2 \%$, przemysłu około $21 \%$ i usług około $76 \%$.

4. Działalnością dominującą wśród wszystkich sekcji usługowych zarówno pod względem wartości dodanej brutto, jak i poziomu zatrudnienia jest handel i naprawy. Najmniejszy udział wykazują gospodarstwa domowe zatrudniające pracowników oraz wytwarzające produkty na własne potrzeby. Niewielki udział sekcji: zakwaterowanie i gastronomia, działalności związanej z kultura, rozrywką i rekreacją, edukacji czy ochrony jest cechą charakterystyczną dla państw słabiej rozwiniętych. Wysoki udział wymienionych usług określanych jako konsumpcyjne świadczy o zamożności i wysokim rozwoju społeczeństwa danego kraju.

5. Wśród podmiotów gospodarczych zarejestrowanych w rejestrze REGON największy udział w ostatnich latach także wykazywały przedsiębiorstwa handlowe i o charakterze naprawczym.

Porównując sektor usług z pozostałymi sektorami gospodarki usługi rozwijały się najbardziej dynamicznie. Niemniej jednak wysoki udział wartości dodanej brutto i zatrudnienia nie zawsze musi oznaczać wysoki poziom rozwoju gospodarczego, tylko niektóre rodzaje usług mogą świadczyć o rozwoju gospodarczym.

7. Zastosowanie do badania analizy czynnikowej pozwoliło na znalezienie nowych zmiennych, które dobrze opisują poziom rozwoju sektora usług.

8. Badanie wykazało znaczne zróżnicowanie pracujących w sektorze usług według województw $(66,48 \%$ w 2010 w województwie mazowieckim i 42,27\% w województwie podkarpackim). 
9. Podobne spostrzeżenia dotyczą wartości dodanej brutto, tutaj także największy udział wykazywało województwo mazowieckie $(76,58 \%)$, natomiast najniższy województwo świętokrzyskie (56,06\%) i śląskie $(57,72 \%)$.

10. We wszystkich województwach Polski w badanym okresie obserwowano wzrost udziału sektora usługowego w liczbie pracujących oraz wartości dodanej brutto. W układzie regionalnym występuje duże zróżnicowanie, będące istotnym problemem. W 2010 r. województwa: mazowieckie, śląskie, wielkopolskie i dolnośląskie wytworzyły ponad 50\% krajowego PKB. W 2010 r. we wszystkich województwach zaobserwowano ponad $70 \%$ udział podmiotów gospodarczych należących do sektora usług, przy czym najwyższy w województwie mazowieckim (78,63\%), a najniższy w wielkopolskim $(72,85 \%)$. Znaczne dysproporcje $\mathrm{w}$ lokalizacji przedsiębiorstw usługowych oznaczają słabszy dostęp do wielu rodzajów usług zwłaszcza dla mieszkańców terenów wiejskich.

11. We wszystkich województwach największy udział wykazała sekcja handel i naprawy.

12. Wykorzystanie w badaniu skalowania wielowymiarowego pozwoliło na zaobserwowanie dużego podobieństwa pomiędzy województwem małopolskim, dolnośląskim i wielkopolskim, potwierdziło także opinię na temat intensywnego rozwoju sektora usług w województwie śląskim i mazowieckim.

13. Za pomocą miar Helwiga i Perkala dokonano grupowania województw ze względu na poziom rozwoju sektora usług. Wśród przodujących województw znalazło się województwo śląskie, natomiast na ostatnim miejscu znajduje się województwo małopolskie.

14. Trójsektorowa struktura pracujących oraz wartości dodanej brutto w Unii Europejskiej charakteryzuje się wyraźną dominacją sektora usług. Pod względem poziomu rozwoju sektora usług Polskę w porównaniu z najlepiej rozwiniętymi państwami Unii Europejskiej dzieli znaczny dystans. W dłuższym okresie obserwowane są procesy upodobniania się struktur trójsektorowych, w ramach których polska gospodarka powoli zmniejsza dystans względem wyżej rozwiniętych państw Unii Europejskiej.

Przytoczone wnioski dają obraz sytuacji rozwoju sektora usług w porównaniu z innymi sektorami, przedstawiają rozwój w poszczególnych województwach i na tle innych państw Unii Europejskiej.

Przejdźmy do oceny innowacyjności przedsiębiorstw sektora usług. 



\section{DZIAŁALNOŚĆ INNOWACYJNA PRZEDSIĘBIORSTW SEKTORA USŁUG}

\subsection{Uwagi wstępne}

Podstawowym działaniem mającym na celu zwiększenie znaczenia sektora usług powinno być dążenie do podejmowania działań poprawiających wydajność pracy zatrudnionych w usługach. Natomiast głównym czynnikiem przyczyniającym się do poprawy wydajności są innowacje, ułatwiające lepsze wykorzystanie zasobów. Celem podejmowania działalności innowacyjnej w sektorze usług jest poprawa jakości oferowanych usług Jednak okazuje się, że w ostatnich czasach innowacyjność ma znacznie szersze znaczenie. Innowacyjność to przetrwanie, szansa na utrzymanie się na rynku, rozwój oraz odniesienie sukcesu w warunkach silnej konkurencji. Wybór podjętej w tym rozdziale problematyki został podyktowany jej aktualnością, wynikającą z rosnącego znaczenia tego sektora $\mathrm{w}$ gospodarce oraz potrzebą powstałą z silnej presji konkurencyjnej, na którą napotykają przedsiębiorstwa. Istotne było także zaobserwowanie zacierania się granic oddzielających działalność przemysłową od usługowej.

$\mathrm{Na}$ postawie badań GUS realizowanych w ramach międzynarodowego programu Community Innovation Survey - CIS - przeprowadzono analizę innowacyjności przedsiębiorstw usługowych na tle działalności innowacyjnej przedsiębiorstw przemysłowych. Zwrócono uwagę na specyfikę innowacji usługowych, źródła ich finansowania, napotykane bariery wzrostu aktywności innowacyjnej. Starano się spojrzeć na innowacje jako element przewagi konkurencyjnej oraz pokazać przebieg procesów innowacyjnych w regionach. Okazuje się, że regiony odgrywają istotną rolę w polityce innowacyjnej, różnią się jednak możliwościami w podejmowaniu działań innowacyjnych.

\subsection{Pojęcie i specyfika innowacyjności w sektorze usług}

Przekonanie, że sektor usług jest mało wrażliwy na potęp technologiczny sprawiło, że przez wiele lat nie interesowano się innowacyjnością usług. Przyczyn braku zainteresowania innowacyjnością usług upatruje się także w niemate- 
rialnej postaci oraz trudnościach w pomiarze. Innowacje w sektorze usług zaczęto dostrzegać w momencie, gdy zauważono, iż pełnią one ważną rolę w procesie innowacyjnym (ujmowanym $\mathrm{w}$ aspekcie makroekonomicznym), co zmieniło postrzeganie podmiotów usługowych jako odbiorców innowacji wytworzonych przez innych. Poza tym dostrzeżono możliwości działań innowacyjnych w innych obszarach niż technologiczny (Niedzielski, Rychlik, Markiewicz 2008). W sektorze usług obserwujemy wyraźny podział na branże opierające swą działalność na zaawansowanej wiedzy i technologii oraz branże działające w sposób tradycyjny nie wykazujące ani potrzeb, ani chęci wprowadzania innowacji. Coraz większe docenianie znaczenia wiedzy i coraz mniejsze zwracanie uwagi na tradycyjne czynniki materialne sprawiło, że problem innowacyjności sektora usług wywoływał coraz większe zainteresowanie. Tendencje te obserwowane są od końca ubiegłego wieku i jest to związane z rozwojem gospodarek państw najwyżej rozwiniętych. Wzrost znaczenia sektora usług we współczesnej gospodarce oraz rola innowacji w rozwoju społeczno-gospodarczym sprawiły, że rzeczą konieczną staje się dogłębna analiza zachodzących w sektorze usług innowacji.

W literaturze wskazuje się na trzy podejścia do problematyki innowacji w sektorze usług (Łobacz, Niedzielski 2012, s. 42):

- podejście asymilacyjne (assimilation approach),

- podejście demarkacyjne (demarcation approach),

- podejście syntetyczne (synthesis approach).

Podejście asymilacyjne reprezentował Schumpeter. W podejściu tym zakłada się, że występuje podobieństwo $\mathrm{w}$ działaniach innowacyjnych $\mathrm{w}$ sektorach usługowym i przemysłowym. Istnieje możliwość przenoszenia koncepcji stworzonych dla sektora przemysłowego do sektora usługowego.

W podejściu demarkacyjnym zwraca się uwagę na unikatowy charakter usług, a w związku z tym na konieczność odmiennego podejścia do działań innowacyjnych w sektorze usług.

Podejście syntetyczne jest łączy w sobie podejście asymilacyjne i demarkacyjne. Zakłada się, że usługi i przemysł w zakresie innowacji nie wykazują istotnych różnic. Głębsza analiza różnic (podejście demarkacyjne) zwraca jednak uwagę na aspekty innowacji, mające szczególne znaczenie w sektorze usługowym.

Według Łobacz i Niedzielskiego (2012) niezależnie od przyjętego podejścia podmioty usługowe powinny być traktowane jako równi partnerzy w procesach innowacyjnych. Wynika to $\mathrm{z}$ realizowanych przez nich funkcji, które przenikają się z działaniami przedsiębiorstw produkcyjnych, tworząc zintegrowany system innowacyjny.

Pierwszy pojęcie innowacji do nauk ekonomicznych wprowadził w $1911 \mathrm{r}$. Joseph Schumpeter, określając je jako: wprowadzenie na rynek nowych produktów, nowych metod produkcji, znalezienie nowych rynków, nowych źródeł su- 
rowców oraz wprowadzenie nowej organizacji (Schumpeter 1960, s. 27). „Przez innowacyjność gospodarki należy rozumieć zdolność i motywację przedsiębiorstwa do ustawicznego poszukiwania i wykorzystania w praktyce wyników prac badawczych i rozwojowych, nowych koncepcji, pomysłów i wynalazków. Innowacyjność oznacza również doskonalenie i rozwój istniejących technologii produkcyjnych, eksploatacyjnych i dotyczących sfery usług, wprowadzanie nowych rozwiązań w organizacji i zarządzaniu, doskonalenie i rozwój infrastruktury, zwłaszcza dotyczącej gromadzenia, przetwarzania i udostępniania informacji" (Kierunki zwiększania... 2006). Początkowo pojęcie innowacyjności odnoszono do sfery produkcji, obecnie działalność produkcyjna i działalność usługowa wzajemnie się przenikają. Ze względu na niematerialny charakter usług i fizyczną postać produktu pomiędzy innowacjami usługowymi i produkcyjnymi występują pewne różnice, które przedstawiono w tab. 4. 1.

Tablica 4.1. Różnice w działalności innowacyjnej sektora przemysłowego i usługowego

\begin{tabular}{|c|c|c|}
\hline Cecha & Produkcja & Usługi \\
\hline Charakter produktu & $\begin{array}{l}\text { Produkt posiada materialny charak- } \\
\text { ter, jest łatwy do przechowywania. }\end{array}$ & $\begin{array}{l}\text { Niematerialny charakter usługi } \\
\text { wpływa na brak możliwości prze- } \\
\text { chowywania. }\end{array}$ \\
\hline Prawa własności & $\begin{array}{l}\text { Silna ochrona praw własność pole- } \\
\text { gająca na rejestracji wniosku w } \\
\text { odpowiednim urzędzie patentowym } \\
\text { (patenty). }\end{array}$ & Słaba ochrona (prawa autorskie). \\
\hline Źródło badań & $\begin{array}{l}\text { Wewnętrzne źródło badań innowa- } \\
\text { cyjnych. }\end{array}$ & $\begin{array}{l}\text { Badania zwykle zlecane są na ze- } \\
\text { wnątrz. }\end{array}$ \\
\hline $\begin{array}{l}\text { Długość cyklu } \\
\text { innowacji }\end{array}$ & Krótki, prosty cykl inno & $\begin{array}{l}\text { Długi cykl innowacji, o skompliko- } \\
\text { wanym przebiegu wyjątkiem mogą } \\
\text { być usługi informatyczne. }\end{array}$ \\
\hline $\begin{array}{l}\text { Zakres przestrzenny } \\
\text { systemu }\end{array}$ & Krajowy-międzynarodowy. & $\begin{array}{c}\text { Regionalny - krajowy - międzyna- } \\
\text { rodowy. }\end{array}$ \\
\hline $\begin{array}{l}\text { Orientacja } \\
\text { na technologie }\end{array}$ & $\begin{array}{l}\text { „Pchanie" technologii; uwarunko- } \\
\text { wane rozwojem nauki i stanem } \\
\text { technologii. }\end{array}$ & $\begin{array}{l}\text { "Ciagnienie" technologii; zachowa- } \\
\text { niami/wymaganiami klienta i poda- } \\
\text { żą rozwiązań technologicznych. }\end{array}$ \\
\hline $\begin{array}{l}\text { Siły napędowe } \\
\text { innowacji }\end{array}$ & Adaptacja nowych technologii. & Wykwalifikowani pracownicy. \\
\hline
\end{tabular}

Źródło: opracowanie własne na podstawie: Howells (2000).

Rozwój i potrzeba badań nad innowacyjnością sektora usług wynika z wielu powodów, do których z całą pewnością możemy zaliczyć: rozwój społeczeństwa informacyjnego wpływający na powstawanie nowych rodzajów produktów usługowych, wzrost zamożności społeczeństwa czy tempo życia. Zwrócenie uwagi 
na innowacyjność sektora usług jest także związane z podniesieniem efektywności funkcjonowania przedsiębiorstwa poprzez np. redukcję kosztów działania oraz zwiększenie popytu na dany produkt lub usługę. Poziom innowacyjności przedsiębiorstw w dużym stopniu wpływa na kierunki i tempo rozwoju gospodarczego. Innowacyjność jest podstawowym czynnikiem wpływającym na wzrost dobrobytu ekonomicznego państwa. Dążenie do uzyskania przewagi konkurencyjnej poprzez podejmowanie działań inwestycyjnych wpływa na rozwój gospodarczy. Wpływ ten przejawia się poprzez postęp technologiczny i zasób zaangażowanego kapitału, którego poziom wiąże się z konkurencyjnością gospodarki (por. Kwiatkowski, Kucharski 2011). Obecnie obserwujemy dużą aktywność sektora usługowego pod kątem tworzenia nowej wiedzy. Innowacyjność w sektorze usług polega na wprowadzaniu nowych i udoskonalaniu już istniejących usług, produktów, mogących sprostać wymaganiom i wychodzących naprzeciw oczekiwaniom współczesnych usługobiorców.

Według Niedzielskiego (2008) ,innowacją może być nowa usługa, nowy sposób świadczenia usługi i/lub nowy sposób organizacji w usługach, która będzie spełniała wymóg nowatorski oraz przyniesie wymierne korzyści ekonomiczno-społeczne". Innowacja może polegać na wdrożeniu jednej głównej zmiany lub na wprowadzeniu kilku mniejszych, przyrostowych zmian, które łącznie będą stanowić znaczącą zmianę (Innowacje... 2010).

Innowacje określa się także jako „wdrożenie nowego lub istotnie ulepszonego produktu (wyrobu, usługi) lub procesu, nowej metody organizacyjnej lub nowej metody marketingowej $\mathrm{w}$ praktyce gospodarczej, organizacji miejsca pracy lub $\mathrm{w}$ stosunkach $\mathrm{z}$ otoczeniem. Nowy lub istotnie ulepszony produkt zostaje wdrożony, gdy jest wprowadzony na rynek. Nowe procesy, metody organizacyjne lub metody marketingowe zostają wdrożone, kiedy rozpoczyna się ich faktyczne wykorzystywanie w działalności przedsiębiorstwa” (Działalność... 2011). Według tego samego źródła działalność innowacyjna jest rozumiana jako ,angażowanie się przedsiębiorstw w różnego rodzaju działania naukowe, techniczne, organizacyjne, finansowe i komercyjne, które prowadzą lub mają w zamierzeniu prowadzić do wdrożenia innowacji. Niektóre z tych działań mają charakter innowacyjny, natomiast inne nie są nowością, lecz są konieczne do wdrożenia innowacji. Działalność innowacyjna obejmuje także działalność badawczo-rozwojową $(\mathrm{B}+\mathrm{R})$, która jest bezpośrednio związana $\mathrm{z}$ tworzeniem konkretnej innowacji” (Działalność... 2011).

OECD za działalność innowacyjną przyjmuje całokształt działań naukowych, technicznych, organizacyjnych, finansowych i komercyjnych, których celem jest dążenie do wprowadzenia innowacji.

Według Podręcznika Oslo (2008), innowacja to wdrożenie nowego lub znacząco udoskonalonego produktu (wyrobu lub usługi) lub procesu, nowej metody marketingowej lub nowej metody organizacyjnej w praktyce gospodarczej, or- 
ganizacji miejsca pracy lub stosunkach z otoczeniem". We wspomnianym Podręczniku dokonano podziału innowacji na cztery rodzaje:

- innowacje w obrębie produktów,

- innowacje w obrębie procesów,

- innowacje marketingowe,

-innowacje organizacyjne.

Pierwszy rodzaj innowacji, produktowych, polega na wprowadzaniu nowego produktu lub usługi oraz na znacznym udoskonalaniu produktów już istniejących, np. w sposobie świadczenia usługi lub poprzez dodanie do już istniejącej usługi nowych funkcji lub cech.

Innowacje procesowe $\mathrm{w}$ sektorze usług polegają $\mathrm{z}$ kolei na wprowadzaniu istotnych zmian $\mathrm{w}$ metodach produkcji i dostarczaniu produktów. W sektorze usług przykładem innowacji procesowych mogą być działania, zmierzające do wprowadzenia nowych lub udoskonalonych technologii informacyjnokomunikacyjnych. Kolejne dwa typy innowacji są ściśle związane z innowacyjnością sektora usługowego.

Innowacje marketingowe polegają na wprowadzaniu nowych metod marketingowych związanych np. z promocją, dystrybucją czy reklamą. Celem wprowadzenia innowacji marketingowych jest wzrost popytu na dany produkt lub usługe poprzez sprostanie oczekiwaniom klientów, zdobycie nowych rynków oraz umacnianie pozycji danego produktu czy usługi na rynku.

Innowacje organizacyjne mają na celu ulepszanie już istniejących metod organizacyjnych lub wprowadzanie nowych metod, np. w organizacji pracy lub kontaktach z otoczeniem. Wprowadzenie innowacji organizacyjnych służy podniesieniu efektywności firmy poprzez redukcję kosztów organizacyjnych.

Pomykalski (2001, s. 18), opierając się na kryterium dziedziny gospodarki, z której wywodzą się innowacje, lub dziedziny działalności, jakiej innowacje dotycza, wyróżnia innowacje:

- funkcyjne, zaspokajające nowe, wcześniej nieujawnione potrzeby społeczne;

- przedmiotowe, polegające na wprowadzaniu nowych przedmiotów w miejsce dotychczas używanych;

- procesowe, wprowadzające nowe metody wytwarzania, których celem jest usprawnienie procesu produkcji, minimalizacja kosztów oraz poprawa warunków pracy;

- organizacyjne mające na celu ulepszenie organizacji pracy i produkcji.

Innowacje można także podzielić na (Niedzielski 2003, s. 19-25):

- antropocentryczne,

- społeczne,

- biotyczne,

- techniczne. 
Innowacje dzielimy także na tzw. innowacje twarde, związane z procesem wytwórczym i produktem, oraz innowacje miękkie, związane z organizacją pracy, zarządzaniem firmą i marketingiem (Niedzielski, Markiewicz, Rychlik, Rzewuski 2007).

Wyodrębniając kryterium oryginalności zmian, spotykamy się z podziałem na innowacje (Olszański, Piech 2012, s. 29):

- kreatywne, które polegają na zastosowaniu nowych rozwiazzań;

- imitacyjno-adaptacyjne, uwzględniające kopiowanie, upowszechnianie i imitacje.

$\mathrm{Z}$ uwagi na heterogeniczność sektora usług wyodrębniono dwie grupy usług charakteryzujące się najwyższą podatnością na innowacyjność. Pierwszą grupę stanowią usługi oparte na zaawansowanej wiedzy (KIS - Knowledge - Intensive Services), druga usługi oparte na wysoko zaawansowanej technologii (high-tech KIS-high-tech Knowledge-Intensive Services) (Węgrzyn 2007 za Felix 2006).

Do pierwszej grupy usług zalicza się (Węgrzyn 2007b, s. 11):

- transport wodny i powietrzny,

- pocztę i telekomunikację,

- pośrednictwo finansowe,

- obsługę nieruchomości i firm,

- edukację,

- ubezpieczenia i fundusze emerytalno-rentowe,

- rekreację, kulturę i sport.

Druga grupa usług oparta na wysoko zaawansowanej technologii składa się z następujących sekcji:

- poczty i telekomunikacji,

- działalności badawczo-rozwojowej,

- informatyki.

W rozważaniach nad pojęciem i rodzajami innowacji warto także zwrócić uwage na cechy innowacji, do których należy zaliczyć interakcyjność i multidyscyplinarność. Wynika stąd, że innowacja jest procesem wielosekwencyjnym, składającym się $\mathrm{z}$ odrębnych, ale równocześnie sprzężonych i współzależnych faz. Kolejna cecha wynika $z$ istoty czynników wpływających na innowacje, są to np.: nabyte doświadczenie, wykształcenie, pozyskane kontakty z użytkownikami i dostawcami, obserwacja działań konkurencji.

Specyficzne cechy usług przedstawione $\mathrm{w}$ rozdziale pierwszym oraz ich niematerialny charakter wpływają na odmienność wdrażania innowacyjności w sektorze usług i w sektorze przemysłowym. W sektorze usług, częściej niż w przemyśle, wprowadza się tzw. innowacje miękkie (organizacyjne), innowacje produktowe i procesowe są wdrażane nieco rzadziej. Na rozwój innowacyjności wpływa wiele czynników, zarówno tzw. czynników zewnętrznych, jak i wewnętrznych. Do czynników zewnętrznych zaliczamy: postęp technologiczny, zmieniające się preferencje i oczekiwania odbiorców, skracanie cyklu życia pro- 
duktu oraz wzrastającą konkurencję (Krawiec 2000). Czynniki wewnętrzne to: sposób zarządzania firma, wynik finansowy, poziom wykształcenia osoby kierującej firmą, kierunek działalności prowadzonego biznesu, wielkość firmy oraz jej postrzeganie na rynku (Mizgajska 2002). Innowacyjność jest uważana za jeden z najważniejszych czynników, mających wpływ na poziom konkurencyjności, dlatego słuszne wydało się podjęcie analizy zachodzących zmian w procesie innowacyjności sektora usług.

\subsection{Innowacja jako element przewagi konkurencyjnej}

Uważa się, że wprowadzanie procesów innowacyjnych jest podstawą uzyskania przez przedsiębiorstwo przewagi konkurencyjnej na rynku. Zarówno badania, jak i doświadczenia państw wysoko rozwiniętych potwierdzają, że osiagnięcie przewagi konkurencyjnej opartej na wiedzy i innowacjach jest podstawą trwałego rozwoju gospodarczego i postępu cywilizacyjnego (Kasperkiewicz 2011 za The Global... 2011). „Pod pojęciem konkurencyjności przedsiębiorstwa rozumie się właściwość, która określa jego zdolność do ciagłego kreowania tendencji rozwojowej, wzrostu produktywności [...] oraz do skutecznego rozwijania rynków zbytu w warunkach oferowania przez konkurentów towarów lub/i usług nowych, lepszych i tańszych" (Adamkiewicz 2001, s. 1). Konkurencyjność można także określić jako agregat złożony z czterech elementów pomiędzy, którymi zachodzą relacje przyczynowo-skutkowe, są to (Rybak 2003, s. 11):

- potencjał konkurencyjności przedsiębiorstwa umożliwiający efektywne działanie na rynku,

- przewaga konkurencyjna, której osiągnięcie jest możliwe w wyniku realizacji odpowiedniej strategii,

- instrumenty konkurowania o klienta prowadzące do uzyskania założonego celu (narzędzia, metody pozyskania klientów),

- pozycja konkurencyjna sprzedającego będąca oceną rynku.

Przedsiębiorstwo w celu utrzymania przewagi konkurencyjnej na rynku powinno posiadać odpowiedni kapitał, nowoczesne technologie, wysoko wykwalifikowanych pracowników, umiejętność szybkiego reagowania na sygnały płynące $\mathrm{z}$ rynku, powinno także umiejętnie zdobywać i przetwarzać informacje oraz wprowadzać innowacje (Kuczewska 2007).

Przewaga konkurencyjna polega na takich działaniach, które są w stanie zapewnić danej firmie lepszą pozycję w stosunku do firm konkurencyjnych (por. Obłój 2004). Na przewagę konkurencyjną wpływa wiele czynników, między innymi: rzadkość zasobów, trudności w naśladowaniu, brak substytutów i inne. Konkurowanie między firmami może przybierać różne formy, do których możemy zaliczyć (Flejterski, Panasiuk, Perenc, Rosa 2005): 
- oferowanie zróżnicowanej struktury usług;

- udoskonalanie proponowanych usług poprzez dodawanie nowych elementów lub zamianę na inne;

- skracanie cyklu życia usług i oferowanie w to miejsce czegoś nowego, niepowtarzalnego;

- ukształtowanie danej usługi w świadomości usługobiorców jako jedynej, unikalnej i wyjątkowej;

- zapewnienie dobrej ceny i odpowiednich warunków płatności;

- kontakt firmy z rynkiem, odpowiednią komunikację;

- oferowanie usług w dogodnym dla klienta miejscu i czasie, przy wykorzystaniu wiedzy logistycznej;

- profesjonalną obsługę klientów;

- dbałość o otoczenie materialne świadczonych usług.

Bodźcami wpływającymi na podejmowanie przez firmy działań innowacyjnych są konkurencja, popyt, rynki zbytu oraz redukcja kosztów wpływająca na zysk firmy (Podręcznik Oslo 2008). Ministerstwo Gospodarki w pracy Kierunki zwiększania innowacyjności gospodarki na lata 2007-2013(2006) zwraca uwage na wyczerpywanie się dotychczasowych źródeł wzrostu gospodarczego w postaci: niskich kosztów pracy, dostępu do tanich surowców, korzystnego położenia geograficznego oraz przystapienia do Unii Europejskiej. Doświadczenia państw wysoko rozwiniętych wskazują natomiast, że uzyskanie przewagi konkurencyjnej jest możliwe poprzez budowanie gospodarki opartej na wiedzy i innowacyjnej.

Innowacyjność sektora usług ma swój wyraz we wdrażaniu nowych technologii i nowej organizacji funkcjonowania firmy. Celem wprowadzania działań innowacyjnych jest poprawa jakości oferowanych usług prowadząca do przewagi konkurencyjnej firmy. Uważa się, że zmiany o charakterze usługowym można uznać za innowacyjne w momencie, gdy wywierają istotny, dający się zmierzyć wpływ na wyniki przedsiębiorstwa, np. wzrost zysków poprzez wzrost produkcji czy sprzedaży (Rudawska 2009). Lepsze wyniki przedsiębiorstwo może także osiągnąć, zmniejszając koszty poprzez np. wprowadzenie energooszczędnych maszyn wymagających mniejszego zatrudnienia.

Dominująca rola usług $\mathrm{w}$ gospodarce oraz wzrost znaczenia innowacji w rozwoju społeczno-gospodarczym przemawia za zwróceniem szczególnej uwagi na działalność innowacyjną przedsiębiorstw w sektorze usług. Innowacje w sektorze usług niejednokrotnie są trudne do zidentyfikowania, a ich pomiar kłopotliwy. W ocenie innowacyjności najczęściej branymi pod uwagę wskaźnikami są: liczba wdrożonych technologii, wprowadzonych na rynek nowych produktów, zmian organizacyjnych, wielkość wydatków na działalność badawczorozwojową oraz liczba zatrudnionych w tej komórce pracowników. Uważa się, że decydujący wpływ na innowacyjność sektora usług ma zdolność firmy do tworzenia, pozyskiwania i zarządzania wiedzą. Przeprowadzone w ostatnich 
latach badania (Działalność... 2011) wskazują na pewne tendencje w zakresie innowacyjności w sektorze usług, mianowicie sektor usług coraz większą uwagę przywiązuje do działalności $\mathrm{B}+\mathrm{R}$. Badania potwierdzają że innowacje sektora usług w dużej mierze zależą od wprowadzania nowoczesnych technologii. Przemiany gospodarcze, powstawanie gospodarki opartej na wiedzy i informacji oraz postęp technologiczny doprowadziły do wzrostu znaczenia innowacyjności postrzeganej jako przewaga konkurencyjna.

\subsection{Poziom i kierunki rozwoju innowacyjności w sektorze usług}

Prowadzenie działalności innowacyjnej w sektorze usług ma na celu poprawę jakości oferowanych usług. Poziom innowacyjności w sektorze usług jest uwarunkowany wieloma czynnikami, do których można zaliczyć: zasoby ludzkie, nakłady finansowe, współpracę sfery $\mathrm{B}+\mathrm{R}$ z firmami usługowymi, branżę prowadzonej działalności, wielkość przedsiębiorstwa i inne.

Nakłady finansowe poniesione na działalność innowacyjną w zakresie innowacji produktowych i procesowych obejmują następujące rodzaje wydatków (Działalność... 2011):

- zakup wiedzy ze źródeł zewnętrznych (patenty, licencje, wynalazki, projekty, wzory użytkowe i przemysłowe, znaki towarowe, usługi techniczne mające na celu wdrażanie innowacji produktowych i procesowych);

- zakup oprogramowania związany z wdrażaniem innowacji produktowych i procesowych;

- zakup i montaż maszyn i urządzeń technicznych (zakup wszelkich środków i narzędzi służących wdrażaniu innowacji produktowych i procesowych);

- szkolenie personelu związane z działalnością innowacyjną;

- wydatki marketingowe, dotyczące nowych lub istotnie ulepszonych produktów związane z badaniami rynku, reklamą;

- działania badawcze i rozwojowe $(\mathrm{B}+\mathrm{R})$ poświęcone opracowaniu nowych lub istotnie ulepszonych produktów i procesów;

- inne czynności, polegające na przygotowaniu do wprowadzenia innowacji produktowych lub procesowych, np. testowanie nowych produktów.

Nakłady na działalność innowacyjną pochodzą ze środków własnych przedsiębiorstw, z budżetu państwa, mogą być pozyskiwane z zagranicy, funduszy kapitału ryzyka, kredytów bankowych oraz z innych źródeł.

W ostatnim dziesięcioleciu zainteresowanie działalnością innowacyjną przedsiębiorstw usługowych $\mathrm{w}$ polskiej gospodarce nabrało wyraźnego tempa. Badania zostały przeprowadzone zgodnie $\mathrm{z}$ zaleceniami ekspertów OECD i Eurostatu oraz Podręcznika Oslo Manual. Analiza publikowanych danych pozwala zaobserwować zmiany w poziomie rozwoju innowacyjności w sektorze 
usług. W celu dokonania oceny poziomu innowacyjności w sektorze usług wykorzystano wyniki przeprowadzonych na ten temat badań.

Pierwsze badanie na temat działalności innowacyjnej przedsiębiorstw w sektorze usług zostało przeprowadzone przez GUS w 2000 r. w oparciu o kwestionariusz CIS-2. Badanie obejmowało przedsiębiorstwa działające w latach 19971999, zatrudniające powyżej dziewięciu pracowników i zaliczane do następujących kategorii EKD (Działalność... 2005):

- Handel hurtowy i komisowy (dział 51 wg EKD, z wyjątkiem grupy 51.1Sprzedaż hurtowa realizowana na zasadzie bezpośredniej płatności lub kontraktu),

- Transport lądowy, wodny i powietrzny (działy 60-62),

- Poczta i telekomunikacja (dział 64),

- Pośrednictwo finansowe (sekcja J),

- Informatyka i działalność pokrewna (dział 72),

- Działalność w zakresie architektury, inżynierii i pokrewne doradztwo techniczne (grupa 74.2).

Wyniki drugiego badania przeprowadzonego w 2004 r. w oparciu o kwestionariusz CIS-3 zostały opublikowane w 2005 r. i obejmowały lata 2001-2003. Badaniem objęto następujące kategorie PKD (Działalność... 2005):

- Handel hurtowy i komisowy z wyłączeniem handlu pojazdami samochodowymi, motocyklami (dział 51wg PKD);

- Transport lądowy, rurociagowy, wodny i lotniczy (działy 60-62);

- Działalność wspomagająca transport; działalność związana z turystyką (dział 63);

- Poczta i telekomunikacja (dział 64);

- Pośrednictwo finansowe (sekcja J);

- Informatyka (dział 72);

- Nauka (dział 73);

- Działalność w zakresie architektury, inżynierii (grupa 74.2);

- Badania i analizy techniczne (grupa 74.3).

W 2007 r. GUS przeprowadził następne badanie na temat działalności innowacyjnej przedsiębiorstw w przemyśle i sektorze usług, w oparciu o kwestionariusz CIS-2006, obejmujące lata 2004-2006.

Kolejne badania na temat innowacyjności w sektorze usług obejmują lata 2006-2008, w celu zachowania ciagłości analizy innowacyjności zostało także przeprowadzone badanie skrócone obejmujące lata 2007-2009. Wyniki badań za lata 2006-2008 podano według PKD 2004, jak też przeliczono według PKD 2007; wyniki za lata 2007-2009 podano zgodnie z PKD 2007.

Ostatnie badanie nad innowacyjnością sektora usług przeprowadzono w $2011 \mathrm{r}$. na pełnej zbiorowości podmiotów, obejmując lata 2008-2010. Badania pozwalają na ocenę innowacyjności przedsiębiorstw usługowych w zakresie: wprowadzonych innowacji produktowych, procesowych, organizacyjnych i marketingowych, 
sprzedaży produktów nowych lub istotnie ulepszonych oraz nakładów na działalność innowacyjną. Działalność innowacyjna przedsiębiorstw może być prowadzona między innymi w celu (Działalność... 2011):

- zwiększenia asortymentu oferowanych wyrobów lub usług;

- zastapienia przestarzałych produktów lub procesów nowymi lub znacznie ulepszonymi;

- pozyskania nowych rynków lub zwiększenia udziału w rynku, na którym produkt już istnieje;

- poprawy jakości oferowanych wyrobów lub usług;

- poprawy elastyczności produkcji;

- zwiększenia zdolności produkcyjnych dla wyrobów lub usług;

- zmniejszenia osobowych kosztów pracy na jednostkę produktu;

- zmniejszenia materiałochłonności i energochłonności na jednostkę produktu;

- zmniejszenia szkodliwości dla środowiska;

- poprawy bezpieczeństwa i higieny pracy pracowników.

Ze względu na różnorodność czynników, które mają wpływ na innowacyjność sektora usług, dokonanie oceny innowacyjności jest rzeczą dość skomplikowaną, wymagającą analizy wielu różnych wskaźników. Do najczęściej używanych wskaźników innowacyjności zalicza się: liczbę wdrożonych technologii, produktów, zmian organizacyjnych, wielkość wydatków na $\mathrm{B}+\mathrm{R}$ oraz liczbę osób zatrudnionych $\mathrm{w}$ komórkach zajmujących się innowacyjnością. Należy także zauważyć, iż brak jest uniwersalnego miernika, określającego poziom innowacyjności i umożliwiającego porównywalność na poziomie regionu czy krajów. Do oceny poziomu innowacyjności krajów Unii Europejskiej wykorzystywany jest wskaźnik innowacyjności SII (Summmary Innovation Index).

Według wyników badań przeprowadzonych przez GUS za lata 2008-2010 (Działalność... 2011) aktywne innowacyjnie przedsiębiorstwa usługowe stanowiły $13,5 \%$ ogólnej liczby przedsiębiorstw, przedsiębiorstwa przemysłowe odpowiednio - 18,1\%. Najwięcej przedsiębiorstw innowacyjnych zarówno w sektorze usługowym $(61,6 \%)$, jak i przemysłowym $(69,6 \%)$ było wśród jednostek dużych zatrudniających powyżej 499 pracowników. Najwyższy odsetek przedsiębiorstw przemysłowych wdrażających innowacje był $\mathrm{w}$ dziale Produkcja podstawowych substancji farmaceutycznych oraz leków i pozostałych wyrobów farmaceutycznych - 54,9\%. W sektorze usług dominowały przedsiębiorstwa innowacyjne $\mathrm{w}$ dziale Ubezpieczenia, reasekuracja oraz fundusze emerytalne, z wyłączeniem obowiązkowego ubezpieczenia społecznego - $61 \%$.

Uwzględniając podział terytorialny kraju, zauważamy, że najwięcej aktywnych innowacyjnie przedsiębiorstw przemysłowych było w województwie podkarpackim $(21,8 \%)$, natomiast przedsiębiorstwa usługowe dominowały w województwie mazowieckim (16,3\%). Najniższe wartości osiagnnęły województwa łódzkie (14,2\%), a w sektorze usług województwo podlaskie $(9,2 \%)$. 
Zwracając uwagę na rodzaj wprowadzanych innowacji, widzimy, że przedsiębiorstwa usługowe wykazują znacznie mniejsze zapotrzebowanie na nową myśl technologiczną niż przedsiębiorstwa przemysłowe. Mniejsze znaczenie innowacji technologicznych wynika z niematerialnego charakteru usług. Niejednokrotnie jest jednak tak, że innowacje wdrożone w przemyśle przenikają do sektora usług. Udział przedsiębiorstw przemysłowych, które wprowadziły innowacje produktowe, wyniósł $12,1 \%$, a procesowe $12,9 \%$. W sektorze usług w przypadku innowacji produktowych było to $7,9 \%$, zaś procesowych $10 \%$. Zarówno w przemyśle, jak i usługach wyższy był udział przedsiębiorstw, które wprowadziły innowacje procesowe. Specyficzne cechy usług sprawiają, że znacznie większe znaczenie dla sektora usług mają innowacje organizacyjne i marketingowe. W latach 2008-2010 innowacje organizacyjne wprowadziło $13 \%$ przedsiębiorstw przemysłowych, a w przypadku przedsiębiorstw usługowych było to $15,2 \%$. Wśród przedsiębiorstw przemysłowych, które wprowadziły innowacje organizacyjne, w \% ogółu przedsiębiorstw najwyższy udział wykazał dział Produkcja wyrobów tytoniowych $(38,5 \%)$. W sektorze usług najwyższy udział stanowił dział Ubezpieczenia, reasekuracja oraz fundusze emerytalne, z wyłączeniem obowiązkowego ubezpieczenia społecznego $(46,3 \%)$. W przypadku innowacji marketingowych podobnie jak organizacyjnych wyższy był udział przedsiębiorstw usługowych $(15,5)$ niż przemysłowych $(13,5 \%)$. Porównując udział poszczególnych działów w sektorze przemysłowym, najwyższy udział przedsiębiorstw wprowadzających innowacje marketingowe był w dziale Produkcja podstawowych substancji farmaceutycznych oraz leków i pozostałych wyrobów farmaceutycznych $(38,1 \%)$. W sektorze usług były to Ubezpieczenia, reasekuracja oraz fundusze emerytalne, z wyłączeniem obowiązkowego ubezpieczenia społecznego $(46,3 \%)$.

Innowacyjność przedsiębiorstw w dużym stopniu zależy od nakładów na badania i rozwój $(B+R)$ i przyczynia się do wzrostu Produktu Krajowego Brutto (PKB). Nakłady na działalność innowacyjną mogą pochodzić z różnych źródeł, mogą to być środki własne, środki z budżetu państwa, pozyskane z zagranicy, z funduszy kapitału ryzyka, kredytów bankowych oraz innych źródel. W 2010 r. podstawowym źródłem finansowania nakładów innowacyjnych były środki własne przedsiębiorstw, które w przypadku przedsiębiorstw przemysłowych stanowiły $75,2 \%$ wszystkich poniesionych na ten cel nakładów, a w przypadku przedsiębiorstw z sektora usług $85,7 \%$. Jednym ze wskaźników określających poziom innowacyjności jest udział nakładów na działalność B+R w PKB.

W celu szczegółowej oceny działalności innowacyjnej przedsiębiorstw usługowych analizie poddano:

- nakłady według rodzajów działalności innowacyjnej oraz działów PKD w latach 2008-2010,

- przychody ze sprzedaży produktów nowych lub istotnie ulepszonych, 
- wartość Sumarycznego Indeksu Innowacyjności dla państw Unii Europejskiej w latach 2004-2011.

$\mathrm{W}$ tab. 4.2 przedstawiono udział nakładów na $\mathrm{B}+\mathrm{R}$ w $\mathrm{PKB}$.

Tablica 4.2. Udział nakładów na B+R w PKB

\begin{tabular}{|c|c|c|c|}
\hline Rok & $\begin{array}{c}\text { Nakłady na działalność } \\
\text { badawczą i rozwojową } \\
\text { w mln zł }\end{array}$ & PKB w mln zł & $\begin{array}{c}\text { Relacja do PKB } \\
\text { w \% }\end{array}$ \\
\hline 2000 & 4796 & 744378 & 0,64 \\
\hline 2001 & 4858 & 750786 & 0,65 \\
\hline 2002 & 4522 & 771113 & 0,59 \\
\hline 2003 & 4558 & 814922 & 0,56 \\
\hline 2004 & 5155 & 923248 & 0,56 \\
\hline 2005 & 5575 & 983302 & 0,57 \\
\hline 2006 & 5893 & 1060031 & 0,56 \\
\hline 2007 & 6673 & 1176737 & 0,57 \\
\hline 2008 & 7706 & 1275432 & 0,60 \\
\hline 2009 & 9070 & 1443366 & 0,68 \\
\hline 2010 & 10416 & 1416447 & 0,74 \\
\hline & Współczynnik korelacji-0,949. \\
\hline
\end{tabular}

Źródło: obliczenia własne na podstawie danych GUS.

W latach 2000-2010 obserwujemy znaczny wzrost nakładów na B+R. W roku 2000 nakłady na B+R wynosiły 4796 mln zł, w 2010 r. zwiększyły się dwukrotnie i wyniosły $10416 \mathrm{mln}$ zł, a ich udział w PKB wyniósł $0,74 \%$. Pomiędzy nakładami a PKB istnieje silna korelacja dodatnia (współczynnik korelacji Pearsona wynosi 0,949 ). W układzie województw obserwujemy duże zróżnicowanie nakładów na $\mathrm{B}+\mathrm{R}$, wśród wszystkich województw dominuje województwo mazowieckie (w 2010 r. alokowane było 41,2\% bezpośrednich dotacji budżetowych na prace badawczo-rozwojowe) oraz województwa posiadające ośrodki naukowo-badawcze. Zależność nakładów na $\mathrm{B}+\mathrm{R}$ przedstawia rys. 4.1.

Nakłady na działalność badawczo-rozwojową w Polsce, mierzone udziałem ogółu wydatków na tę działalność w PKB w analizowanym okresie w porównaniu z państwami Unii Europejskiej, osiagnęły jedną z niższych wartości (w $2010 \mathrm{r}$. było to $0,74 \%$ ), dając nam jedno $\mathrm{z}$ ostatnich miejsc w UE (por. tab. 4.3). W $2010 \mathrm{r}$. średnia dla UE-27 wyniosła 2,0\%. Najwięcej na B+R w 2010 r. w stosunku do PKB przeznaczono w Finlandii (3,87\%), Szwecji (3,42\%) oraz w Danii (3,06\%), najniższe wartości zaobserwowano w Rumunii $(0,47 \%)$ i na Cyprze $(0,5 \%)$. 


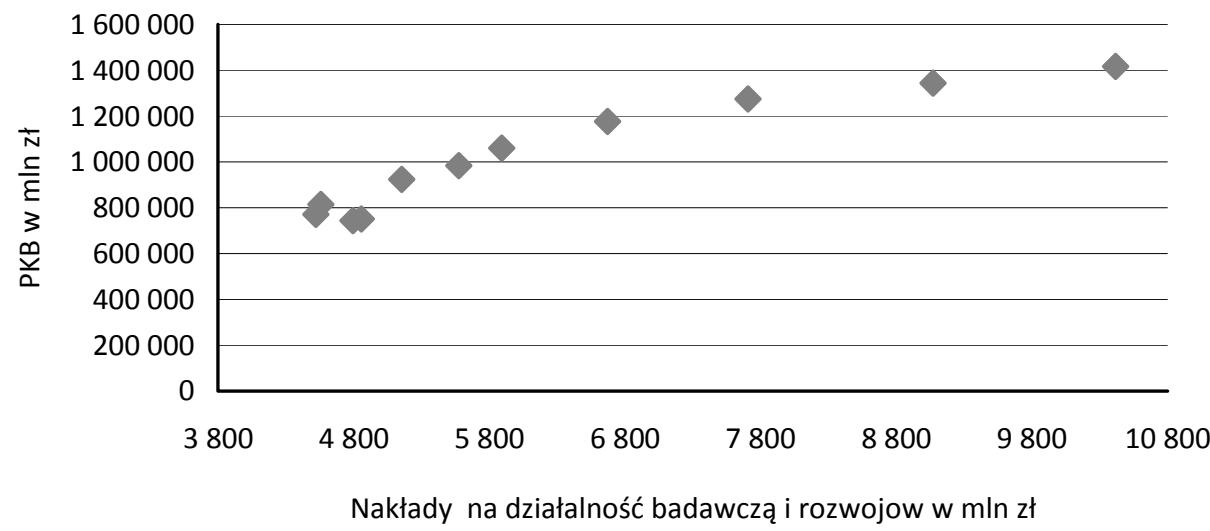

Rys. 4.1. Związek pomiędzy wielkością nakładów na $\mathrm{B}+\mathrm{R}$ a poziomem $\mathrm{PKB}$ Źródło: opracowanie własne na podstawie danych GUS.

Tablica 4.3. Nakłady na działalność badawczą i rozwojową (B+R) w \% PKB w państwach Unii Europejskiej

\begin{tabular}{|l|c|c|c|c|c|c|c|c|c|c|c|c|}
\hline Wyszczególnienie & 1995 & 2000 & 2001 & 2002 & 2003 & 2004 & 2005 & 2006 & 2007 & 2008 & 2009 & 2010 \\
\hline \multicolumn{1}{|c|}{1} & 2 & 3 & 4 & 5 & 6 & 7 & 8 & 9 & 10 & 11 & 12 & 13 \\
\hline Unia Europejska 27 & 1,80 & 1,86 & 1,87 & 1,88 & 1,87 & 1,83 & 1,83 & 1,85 & 1,85 & 1,92 & 2,01 & 2,00 \\
\hline Austria & 1,55 & 1,93 & 2,05 & 2,12 & 2,24 & 2,24 & 2,46 & 2,44 & 2,51 & 2,67 & 2,72 & 2,76 \\
\hline Belgia & 1,67 & 1,97 & 2,07 & 1,94 & 1,87 & 1,86 & 1,83 & 1,86 & 1,89 & 1,97 & 2,03 & 1,99 \\
\hline Bułgaria & 0,62 & 0,51 & 0,46 & 0,48 & 0,48 & 0,49 & 0,46 & 0,46 & 0,45 & 0,47 & 0,53 & 0,60 \\
\hline Cypr & - & 0,25 & 0,26 & 0,30 & 0,35 & 0,37 & 0,41 & 0,43 & 0,44 & 0,43 & 0,49 & 0,50 \\
\hline Dania & 1,82 & 2,24 & 2,39 & 2,51 & 2,58 & 2,48 & 2,46 & 2,48 & 2,58 & 2,85 & 3,06 & 3,06 \\
\hline Estonia & - & 0,60 & 0,70 & 0,72 & 0,77 & 0,85 & 0,93 & 1,13 & 1,08 & 1,28 & 1,43 & 1,62 \\
\hline Finlandia & 2,26 & 3,35 & 3,32 & 3,36 & 3,44 & 3,45 & 3,48 & 3,48 & 3,47 & 3,70 & 3,92 & 3,87 \\
\hline Francja & 2,28 & 2,15 & 2,20 & 2,24 & 2,18 & 2,16 & 2,11 & 2,11 & 2,08 & 2,12 & 2,26 & 2,26 \\
\hline Grecja & 0,43 & 0,60 & 0,58 & - & 0,57 & 0,55 & 0,60 & 0,59 & 0,60 & - & - & - \\
\hline Hiszpania & 0,79 & 0,91 & 0,92 & 0,99 & 1,05 & 1,06 & 1,12 & 1,20 & 1,27 & 1,35 & 1,39 & 1,39 \\
\hline Irlandia & 1,25 & 1,11 & 1,09 & 1,09 & 1,16 & 1,22 & 1,24 & 1,24 & 1,28 & 1,45 & 1,74 & 1,79 \\
\hline Litwa & 0,43 & 0,59 & 0,67 & 0,66 & 0,67 & 0,75 & 0,75 & 0,79 & 0,81 & 0,79 & 0,83 & 0,79 \\
\hline Luksemburg & - & 1,65 & - & - & 1,65 & 1,63 & 1,56 & 1,66 & 1,58 & 1,57 & 1,66 & 1,63 \\
\hline Lotwa & 0,47 & 0,45 & 0,41 & 0,42 & 0,38 & 0,42 & 0,56 & 0,70 & 0,60 & 0,62 & 0,46 & 0,60 \\
\hline Malta & - & - & - & 0,26 & 0,25 & 0,53 & 0,57 & 0,62 & 0,58 & 0,56 & 0,54 & 0,63 \\
\hline Niderlandy & 1,97 & 1,94 & 1,93 & 1,88 & 1,92 & 1,93 & 1,90 & 1,88 & 1,81 & 1,77 & 1,82 & 1,83 \\
\hline Niemcy & 2,19 & 2,47 & 2,47 & 2,50 & 2,54 & 2,50 & 2,51 & 2,54 & 2,53 & 2,69 & 2,82 & 2,82 \\
\hline Polska & 0,63 & 0,64 & 0,62 & 0,56 & 0,54 & 0,56 & 0,57 & 0,56 & 0,57 & 0,60 & 0,68 & 0,74 \\
\hline Portugalia & 0,52 & 0,73 & 0,77 & 0,73 & 0,71 & 0,75 & 0,78 & 0,99 & 1,17 & 1,50 & 1,64 & 1,59 \\
\hline Republika Czeska & 0,91 & 1,17 & 1,16 & 1,15 & 1,20 & 1,20 & 1,35 & 1,49 & 1,48 & 1,41 & 1,48 & 1,56 \\
\hline
\end{tabular}


Tablica 4.3 (cd.)

\begin{tabular}{|l|c|c|c|c|c|c|c|c|c|c|c|c|}
\hline \multicolumn{1}{|c|}{1} & 2 & 3 & 4 & 5 & 6 & 7 & 8 & 9 & 10 & 11 & 12 & 13 \\
\hline Rumunia & 0,75 & 0,37 & 0,39 & 0,38 & 0,39 & 0,39 & 0,41 & 0,45 & 0,52 & 0,58 & 0,47 & 0,47 \\
\hline Słowacja & 0,92 & 0,65 & 0,63 & 0,57 & 0,57 & 0,51 & 0,51 & 0,49 & 0,46 & 0,47 & 0,48 & 0,63 \\
\hline Słowenia & 1,52 & 1,38 & 1,49 & 1,47 & 1,27 & 1,39 & 1,44 & 1,56 & 1,45 & 1,65 & 1,86 & 2,11 \\
\hline Szwecja & 3,26 & 3,58 & 4,13 & - & 3,80 & 3,58 & 3,56 & 3,68 & 3,40 & 3,70 & 3,61 & 3,42 \\
\hline Węgry & 0,72 & 0,81 & 0,93 & 1,00 & 0,94 & 0,88 & 0,94 & 1,01 & 0,98 & 1,00 & 1,17 & 1,16 \\
\hline Wielka Brytania & 1,91 & 1,81 & 1,79 & 1,79 & 1,75 & 1,68 & 1,73 & 1,75 & 1,78 & 1,79 & 1,86 & 1,77 \\
\hline Włochy & 0,97 & 1,04 & 1,08 & 1,12 & 1,10 & 1,09 & 1,09 & 1,13 & 1,17 & 1,21 & 1,26 & 1,26 \\
\hline
\end{tabular}

Źródło: www.stat.gov.pl [10.09 2012].

Ilustrację graficzną nakładów na działalność badawczo-rozwojową w roku 1995 i 2010 przedstawia rys. 4.2. Na rysunku zaznaczono średni poziom nakładów dla państw UE, dzięki czemu łatwiej możemy zaobserwować państwa o najwyższych nakładach na ten cel.

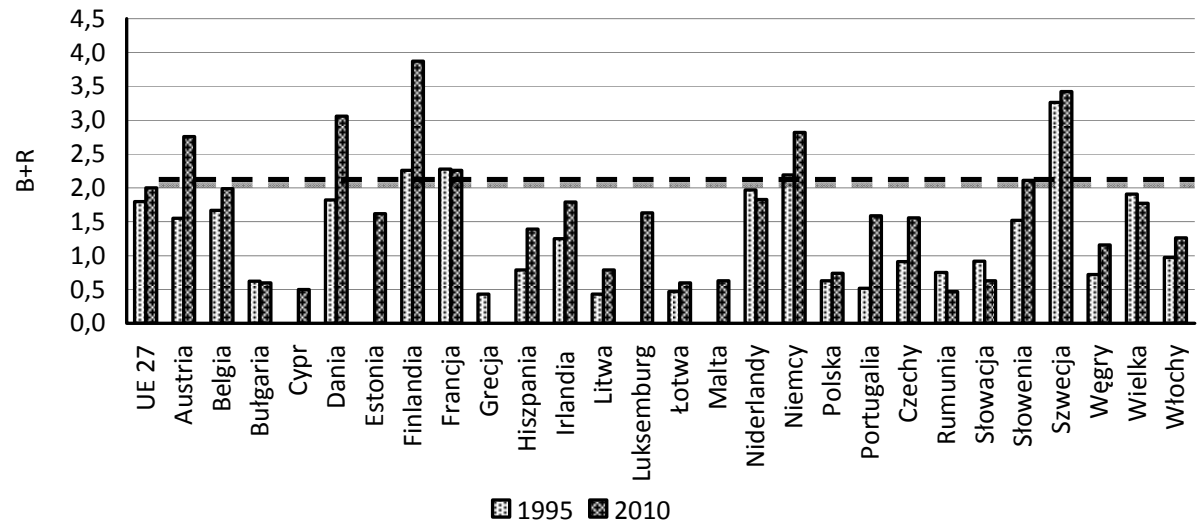

Rys. 4.2. Nakłady na B+R w \% PKB w krajach Unii Europejskiej w 1995 i 2010 r.

Źródło: opracowanie własne na podstawie: www.stat.gov.pl [10.10.2012].

Badania statystyczne oraz raporty UE, OECD, Banku Światowego wskazują na duże różnice w poziomie innowacyjności Polski i państw wysoko rozwiniętych. Porównując udział nakładów na $\mathrm{B}+\mathrm{R}$ w PKB w Polsce z państwami Unii Europejskiej, zauważamy, że Polska nie wypada najlepiej. W 2009 r. wskaźnik relacji nakładów na B+R do PKB dla Finlandii wyniósł 3,96\%, Szwecji $3,61 \%$, Danii - 3,02\%, Austrii - 2,75\%, Niemiec - 2,78\%, Wielkiej Brytanii $1,85 \%$, natomiast dla Polski $0,68 \%$. W roku 2010 najwyższy wskaźnik także osiągnęła Finlandia - 3,87 i Szwecja-3,42. 
Analizując wskaźniki świadczące o poziomie innowacyjności sektora usług, słuszne wydało się porównanie wielkości nakładów ponoszonych w przedsiębiorstwach przemysłowych (tab. 4.4) z przedsiębiorstwami usługowymi (tab. 4.5). W roku 2006 wartość nakładów w przemyśle przekroczyła 17 mld zł, w sektorze usług było to ponad $8 \mathrm{mld}$ zł. Na jedno przedsiębiorstwo przemysłowe kwota nakładów wynosiła 3206,0 tys. zł, w sektorze usług w 2006 r. nakłady innowacyjne przypadające na jedno przedsiębiorstwo wynosiły 2648,4 tys. zł.

Tablica 4.4. Nakłady na działalność innowacyjną według klas wielkości w mln zł w przedsiębiorstwach przemysłowych

\begin{tabular}{|l|r|r|r|r|r|r|r|r|}
\hline \multirow{2}{*}{$\begin{array}{c}\text { Liczba } \\
\text { pracujących }\end{array}$} & 2006 & 2008 & $\begin{array}{c}2008 / \\
2006\end{array}$ & 2009 & $\begin{array}{c}2009 / \\
2008\end{array}$ & 2010 & $2010 / 2009$ & $\begin{array}{c}2010 / \\
2008\end{array}$ \\
\cline { 2 - 9 } & 17841,2 & 24684,0 & 138,4 & 22652,1 & 91,8 & 23757,8 & 104,9 & 96,2 \\
\hline Ogółem & 1283,0 & 997,9 & 77,8 & 1246,6 & 124,9 & 1378,7 & 110,6 & 138,2 \\
\hline $10-49$ & 4189,1 & 4742,0 & 113,2 & 3914,9 & 82,6 & 4515,0 & 115,3 & 95,2 \\
\hline $50-249$ & 2359,6 & 2753,5 & 116,7 & 2840,9 & 103,2 & 2418,6 & 85,1 & 87,8 \\
\hline $250-499$ & 10009,4 & 16190,6 & 161,8 & 14649,6 & 90,5 & 15445,4 & 105,4 & 95,4 \\
\hline Powyżej 499 & & & & & & &
\end{tabular}

Źródło: obliczenia własne na podstawie Działalność innowacyjna przedsiębiorstw $w$ latach 2006-2009 oraz Działalność innowacyjna przedsiębiorstw w latach 2008-2010.

Wielkość nakładów finansowych na działalność innowacyjną jest podstawowym wskaźnikiem służącym do oceny innowacyjności. Ponoszone przez przedsiębiorstwa nakłady są znacznie zróżnicowane, pochodzą z różnych źródeł finansowania i wpływają na wzrost zysków. W roku 2010 nakłady na działalność innowacyjną w przedsiębiorstwach przemysłowych wyniosły $23757,8 \mathrm{mln}$ zł, jednak było to o $3,8 \%$ mniej niż w roku 2008 . Warto zauważyć, że w przypadku przedsiębiorstw z sektora usługowego w roku 2010 nakłady innowacyjne w tym sektorze znacznie przewyższały nakłady w przedsiębiorstwach przemysłowych, wynosząc $10790,3 \mathrm{mln}$ zł. Analiza danych zawartych w tab. 4.4 pozwala stwierdzić, że największe nakłady w przedsiębiorstwach przemysłowych poniosły przedsiębiorstwa zatrudniające powyżej 499 pracowników. W roku 2009 w porównaniu z 2008 r. miał miejsce wzrost nakładów innowacyjnych o około $25 \% \mathrm{w}$ przedsiębiorstwach zatrudniających od 10 do 49 osób oraz w przedsiębiorstwach zatrudniających od 250 do 499 osób o około 3\%. Pewne pozytywne zmiany zaobserwowano w roku $2010 \mathrm{w}$ porównaniu z 2009 r., wyjątkiem były przedsiębiorstwa zatrudniające od 250 do 499 pracowników, w których miał miejsce $15 \%$ spadek nakładów inwestycyjnych. 
Tablica 4.5. Nakłady na działalność innowacyjną według klas wielkości w mln zł w przedsiębiorstwach z sektora usług według wielkości przedsiębiorstw

\begin{tabular}{|l|c|c|c|c|c|c|c|c|}
\hline \multirow{2}{*}{$\begin{array}{c}\text { Liczba pracu- } \\
\text { jących }\end{array}$} & 2006 & \multicolumn{7}{|c|}{ Przedsiębiorstwa z sektora usług } \\
\cline { 3 - 10 } & 2008 & $\begin{array}{c}2008 / \\
2006\end{array}$ & 2009 & $\begin{array}{c}2009 / \\
2008\end{array}$ & 2010 & $\begin{array}{c}2010 / \\
2009\end{array}$ & $\begin{array}{c}2010 \\
/ 2008\end{array}$ \\
\hline Ogółem & 8268,4 & 10664,8 & 129,0 & 8260,1 & 77,5 & 10790,3 & 130,6 & 101,2 \\
\hline $10-49$ & 1037,6 & 870,2 & 83,9 & 635,8 & 73,1 & 869,2 & 136,7 & 99,9 \\
\hline $50-249$ & 1001,7 & 3301,3 & 329,6 & 872,4 & 26,4 & 916,1 & 105,0 & 27,7 \\
\hline $250-499$ & 516,2 & 503,6 & 97,6 & 276,1 & 54,8 & 854,2 & 309,4 & 169,6 \\
\hline Powyżej 499 & 5712,9 & 5989,7 & 104,8 & 6475,7 & 108,1 & 8050,7 & 124,3 & 134,4 \\
\hline
\end{tabular}

Źródło: obliczenia własne na podstawie Działalność innowacyjna przedsiębiorstw $w$ latach 2006-2009 oraz Działalność innowacyjna przedsiębiorstw w latach 2008-2010.

Działania innowacyjne wymagają nakładów finansowych, którym same przedsiębiorstwa nie zawsze są w stanie podołać. Istnieje wiele różnych sposobów i źródeł finansowania działalności innowacyjnej przedsiębiorstw. Możliwości uzyskania środków na działania innowacyjne zależą od etapu rozwoju firmy i celu finansowania. Na rys. 4.3. przedstawiono poziom nakładów na działalność innowacyjną w przemyśle i sektorze usługowym.

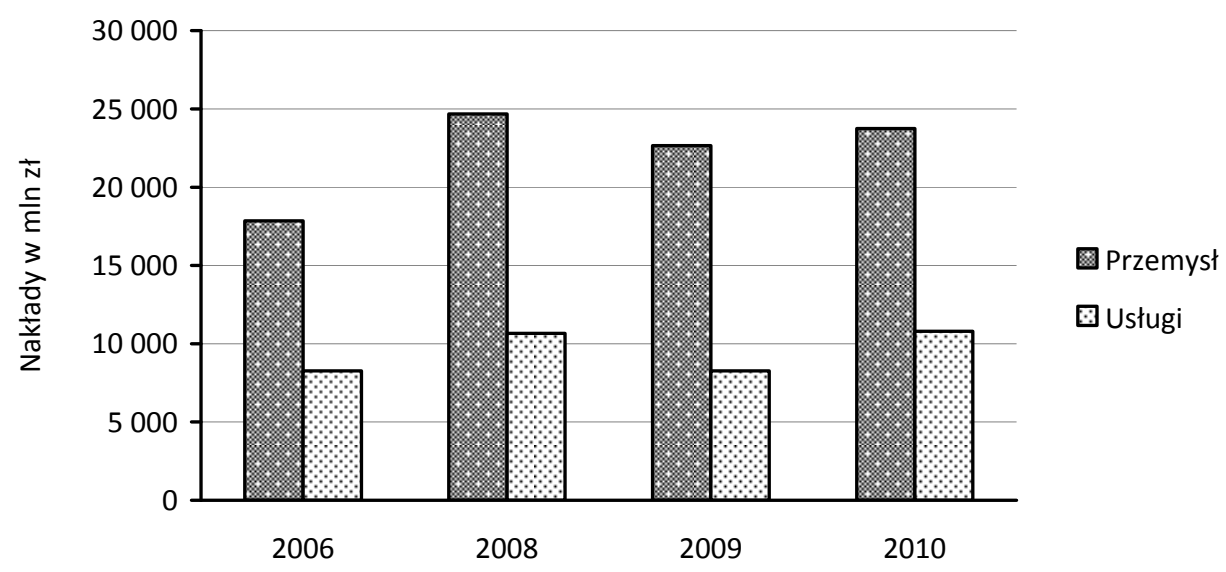

Rys. 4. 3. Nakłady na działalność innowacyjną w przemyśle i usługach

Źródło: opracowanie własne na podstawie Działalność innowacyjna przedsiębiorstw $w$ latach 2006-2009 oraz Działalność innowacyjna przedsiębiorstw w latach 2008-2010.

Na rys. 4.3 wyraźnie widać przewagę nakładów innowacyjnych w sektorze przemysłowym nad sektorem usługowym. 
W roku 2010 największa liczba przedsiębiorstw należących do sektora usługowego była zarejestrowana w województwie mazowieckim, śląskim oraz wielkopolskim, najmniej przedsiębiorstw usługowych było w województwie opolskim, świętokrzyskim oraz podlaskim. Wysoki poziom innowacyjności przedsiębiorstw działających w sektorze usług jest warunkiem unowocześniania ekonomicznego regionów. Analizując nakłady na działalność innowacyjną w przekroju terytorialnym, zauważamy, że najwyższe nakłady w 2006 r. poniosło województwo mazowieckie, na jedno przedsiębiorstwo prowadzące działalność innowacyjną przypadało 7061,1 tys. zł. Najniższe kwoty przypadające na jedno przedsiębiorstwo poniosło województwo opolskie 337,4 tys. zł oraz warmińskomazurskie - 388,3 tys. zł. W roku 2010 najwyższe nakłady na działalność innowacyjną także poniosło województwo mazowieckie, najniższe nakłady przypadły na województwo podlaskie (tab. 4.6).

Tablica 4.6. Nakłady na działalność innowacyjną w przedsiębiorstwach usługowych oraz podmioty gospodarcze sektora usług w rejestrze REGON według województw

\begin{tabular}{|c|c|c|c|c|c|c|c|c|}
\hline \multirow{2}{*}{$\begin{array}{c}\text { Nazwa } \\
\text { województwa }\end{array}$} & \multicolumn{5}{|c|}{ Nakłady innowacyjne w tys. zł } & \multicolumn{3}{|c|}{$\begin{array}{c}\text { Podmioty sektora usług } \\
\text { w REGON }\end{array}$} \\
\hline & 2009 & 2010 & $\begin{array}{l}2010 / \\
2009 \\
\end{array}$ & 2011 & $\begin{array}{l}2011 / \\
2010 \\
\end{array}$ & 2009 & 2010 & 2011 \\
\hline Dolnośląskie & 588122 & 504565 & 85,79 & 327430 & 64,89 & 247363 & 258172 & 255636 \\
\hline $\begin{array}{l}\text { Kujawsko- } \\
\text { pomorskie }\end{array}$ & - & 54416 & - & 161062 & 295,98 & 138507 & 141059 & 139300 \\
\hline Lubelskie & 61248 & 48474 & 79,14 & 65271 & 134,65 & 121259 & 126572 & 124851 \\
\hline Lubuskie & 12244 & 28421 & 232,12 & 25656 & 90,27 & 77410 & 80692 & 79101 \\
\hline Łódzkie & 25638 & 51267 & 199,96 & 65892 & 128,53 & 163898 & 171599 & 170224 \\
\hline Małopolskie & 384249 & 273106 & 71,08 & 231459 & 84,75 & 233404 & 245533 & 245914 \\
\hline Mazowieckie & 5929840 & 8318375 & 140,28 & 8612000 & 103,53 & 508426 & 535472 & 532907 \\
\hline Opolskie & 19827 & 22837 & 115,18 & 13281 & 58,16 & 70671 & 72990 & 71617 \\
\hline Podkarpackie & 40344 & 75733 & 187,72 & 193788 & 255,88 & 109916 & 114801 & 113352 \\
\hline Podlaskie & 10379 & 9960 & 95,96 & 11842 & 118,9 & 67117 & 68648 & 68618 \\
\hline Pomorskie & 279010 & 456981 & 163,79 & 682766 & 149,41 & 183864 & 192468 & 190996 \\
\hline Śląskie & 403897 & 591906 & 146,55 & 379759 & 64,16 & 334804 & 349667 & 343015 \\
\hline Świętokrzyskie & 28042 & 36733 & 130,99 & 15123 & 41,17 & 80339 & 82086 & 79613 \\
\hline $\begin{array}{l}\text { Warmińsko- } \\
\text { mazurskie }\end{array}$ & - & 95934 & - & 49532 & 51,63 & 86336 & 89271 & 87984 \\
\hline Wielkopolskie & 135677 & 157535 & 116,11 & 96111 & 61,01 & 261921 & 273524 & 274194 \\
\hline $\begin{array}{l}\text { Zachodnio- } \\
\text { pomorskie }\end{array}$ & 68837 & 64039 & 93,03 & 48119 & 75,14 & 164291 & 167916 & 162974 \\
\hline
\end{tabular}

Źródło: obliczenia własne na podstawie Banku Danych Lokalnych, www.stat.gov.pl [29.12.2012]. 
W roku 2006 na jedno przedsiębiorstwo przemysłowe prowadzące działalność innowacyjną przypadało 3206,0 tys. zł, przy czym najwyższe nakłady przypadające na jedno przedsiębiorstwo były w województwie mazowieckim 5502,1 tys. zł. W roku 2010 nakłady finansowe na działalność innowacyjną przypadające na jedno przedsiębiorstwo przemysłowe wyniosły 5749,7 tys. zł, w przypadku przedsiębiorstw z sektora usług było to 5007,1 tys. zł. Zarówno w przedsiębiorstwach przemysłowych, jak i przedsiębiorstwach należących do sektora usług ponoszone nakłady na działalność innowacyjną w zdecydowanej mierze pochodziły z ze środków własnych. W roku $2010 \mathrm{w}$ porównaniu z rokiem 2009 nakłady na działalność innowacyjną wzrosły o ponad 30\% (tab. 4.8). Najwięcej środków finansowych przedsiębiorstwa usługowe przeznaczały na (por. aneks $5,7,8$ ) zakup maszyn i urządzeń technicznych, środków transportowych, narzędzi, przyrządów, ruchomości i wyposażenia $(41,7 \%)$. Najniższe nakłady na działalność innowacyjną przedsiębiorstwa usługowe poniosły na szkolenie personelu. Na rys. 4.4 (brak niektórych danych na wykresie jest spowodowana brakiem informacji w Banku Danych Lokalnych) przedstawiono poziom nakładów innowacyjnych ponoszonych przez przedsiębiorstwa usługowe i przemysłowe według województw. Najwyższe nakłady zarówno w sektorze usługowym, jak i przemysłowym ponosi województwo mazowieckie.

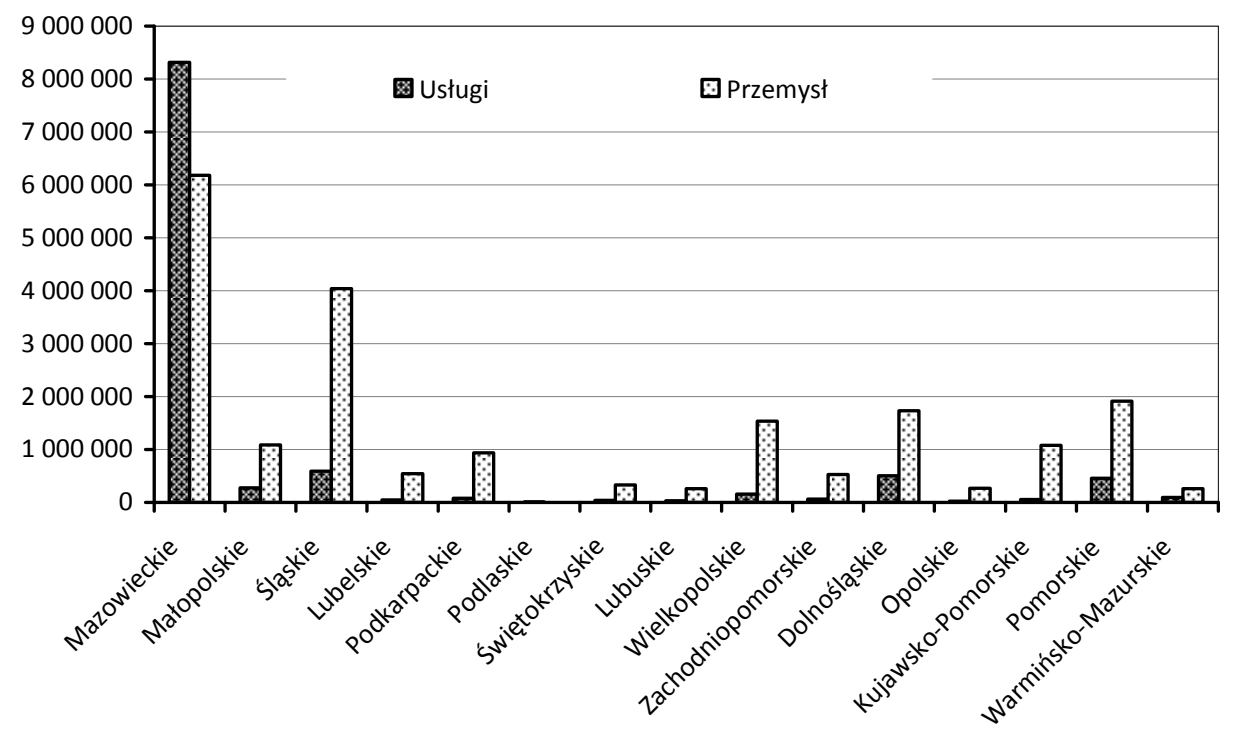

Rys. 4.4. Nakłady na działalność innowacyjną w przedsiębiorstwach usługowych i przemysłowych według województw

Źródło: opracowanie własne na podstawie Banku Danych Lokalnych, www.stat.gov [10.10.2012]. 


\begin{tabular}{|c|c|c|c|c|c|c|c|c|c|c|c|c|c|c|c|c|c|c|}
\hline \multirow{8}{*}{$\begin{array}{l}\Xi \\
\text { 志 } \\
3\end{array}$} & \multicolumn{2}{|c|}{ 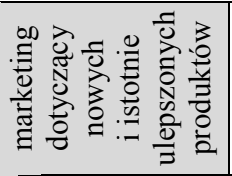 } & $=$ & $\begin{array}{l}0 \\
\hat{a} \\
\hat{a}\end{array} \mid$ & $\stackrel{m}{\stackrel{n}{I}}$ & $\hat{\sigma}$ & $\mid \begin{array}{l}n \\
\infty \\
\infty \\
n\end{array}$ & $\frac{0}{i}$ & $\vec{a}$ & $\left|\begin{array}{c}0 \\
8 \\
0 \\
0\end{array}\right|$ & r. & $\begin{array}{l}n \\
6\end{array}$ & 1 & $\begin{array}{l}0 \\
0\end{array}$ & $\begin{array}{c}0 \\
\ddot{n}\end{array}$ & $\because$ & $\begin{array}{l}0 \\
0 \\
n \\
m\end{array}$ & $\stackrel{0}{0}$ \\
\hline & \multicolumn{2}{|c|}{ 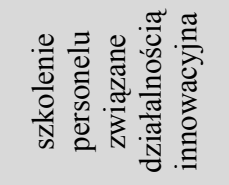 } & 으 & 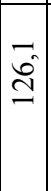 & $\begin{array}{c}0 \\
\hat{a} \\
\hat{n}\end{array}$ & $\begin{array}{l}\vec{v} \\
\stackrel{a}{\Xi}\end{array}$ & $\mid \begin{array}{l}0 \\
\stackrel{a}{I}\end{array}$ & $\frac{\sigma_{0}}{\widehat{\sigma}}$ & 旾 & $\begin{array}{l}0 \\
\hat{i} \\
0\end{array}$ & $\mid \begin{array}{l}+ \\
0 \\
0 \\
ِ\end{array}$ & $\stackrel{m}{\sim}$ & $\begin{array}{l}\hat{2} \\
\tilde{\sigma}\end{array}$ & $\begin{array}{c}m \\
\tilde{m}_{0} \\
0\end{array}$ & $\begin{array}{l}\stackrel{m}{n} \\
\stackrel{n}{=}\end{array}$ & $\approx$ & $\begin{array}{l}\sim \\
\infty \\
\underbrace{\prime}\end{array}$ & $\vec{a}$ \\
\hline & \multirow{3}{*}{ 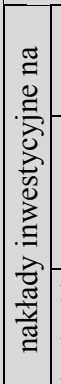 } & 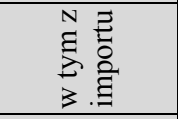 & $a$ & \begin{tabular}{|l|}
0 \\
$\hat{\Omega}$ \\
\end{tabular} & $\overrightarrow{\mathrm{a}}$ & $\hat{\vartheta}$ & $\mid \begin{array}{c}n \\
\infty \\
\infty \\
\sim \\
\end{array}$ & $\begin{array}{l}n \\
m\end{array}$ & $\nabla_{\sigma}$ & $\begin{array}{l}\infty \\
\infty \\
\infty \\
n \\
n\end{array}$ & $\left|\begin{array}{c}n \\
\infty \\
\infty \\
+\end{array}\right|$ & $\underset{\sim}{\stackrel{\sigma}{\sigma}}$ & $\frac{7}{6}$ & $\frac{0}{m}$ & $\stackrel{m}{2}$ & 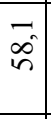 & 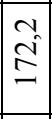 & $\stackrel{0}{8}$ \\
\hline & & 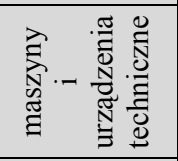 & $\infty$ & 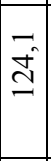 & $\frac{\sigma}{0}$ & $\begin{array}{l}\infty \\
0 \\
0 \\
0\end{array}$ & $\stackrel{\infty}{\Xi}$ & $\stackrel{2}{=}$ & ఫू & $\begin{array}{l}2 \\
\hat{n} \\
n\end{array}$ & $\begin{array}{c}n \\
\infty \\
n \\
n\end{array} \mid$ & $\begin{array}{l}+ \\
i \\
a\end{array}$ & $\begin{array}{l}\infty \\
\infty \\
\infty \\
\infty\end{array}$ & $\begin{array}{l}\partial \\
\dot{I}\end{array}$ & \begin{tabular}{l}
$n$ \\
\hdashline \\
8 \\
8
\end{tabular} & $\begin{array}{l}\simeq \\
=\end{array}$ & $\begin{array}{l}2 \\
\hat{n} \\
\frac{\gamma}{7}\end{array}$ & $\frac{n}{n}$ \\
\hline & & 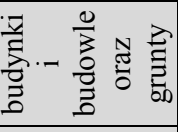 & - & 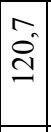 & $\begin{array}{l}\dot{\sigma}_{0} \\
\stackrel{0}{n}\end{array}$ & $\overrightarrow{\infty^{0}}$ & $\begin{array}{l}n \\
\tilde{n} \\
\tilde{n}\end{array}$ & $\begin{array}{l}\tilde{N} \\
\tilde{N}\end{array}$ & خे & $\frac{\partial}{\vec{\gamma}}$ & $\Rightarrow$ & $\begin{array}{l}\infty \\
\stackrel{\sim}{2}\end{array}$ & \begin{tabular}{|l|}
$m$ \\
6 \\
0 \\
$I$
\end{tabular} & 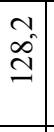 & \begin{tabular}{|l|}
$n$ \\
$\infty$ \\
$\infty$ \\
-
\end{tabular} & $\begin{array}{l}m \\
\stackrel{m}{\sim} \\
\end{array}$ & $\vec{F}$ & $\stackrel{a}{=}$ \\
\hline & & 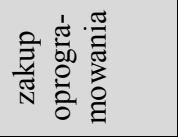 & 6 & \begin{tabular}{|l|}
\multirow{2}{*}{} \\
$\stackrel{f}{\Xi}$
\end{tabular} & 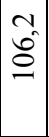 & $\stackrel{\sim}{n}$ & 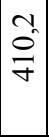 & $\begin{array}{l}0 \\
\overrightarrow{0}\end{array}$ & $\begin{array}{l}n \\
2 \\
\stackrel{2}{n}\end{array}$ & $\begin{array}{l}0 \\
i n \\
i n\end{array}$ & $\begin{array}{l}m \\
2 \\
n \\
m\end{array}$ & $\begin{array}{l}0 \\
\stackrel{0}{0} \\
\stackrel{2}{1}\end{array}$ & $\begin{array}{l}\vec{a} \\
\stackrel{\sim}{0} \\
\dot{N}\end{array}$ & $\begin{array}{l}\sigma_{n} \\
f \\
f\end{array}$ & $\frac{\sim}{-}$ & $\begin{array}{l}0 \\
\infty\end{array}$ & $\overrightarrow{6}$ & $\vec{n}$ \\
\hline & & 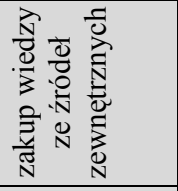 & in & $\begin{array}{l}m \\
m \\
m \\
m\end{array}$ & \begin{tabular}{|l|}
0 \\
$\stackrel{2}{0}$ \\
$\stackrel{2}{ }$
\end{tabular} & \begin{tabular}{l}
$\nabla_{n}$ \\
\multirow{\infty}{\infty}{} \\
$\infty$ \\
$n$
\end{tabular} & $\begin{array}{l}0 \\
0 \\
0\end{array}$ & $\begin{array}{l}n \\
\hat{b} \\
\hat{n}^{0}\end{array}$ & $\sqrt{6}$ & $\frac{a}{2}$ & \begin{tabular}{|c|} 
\\
0 \\
0 \\
0 \\
\end{tabular} & $\begin{array}{l}\infty \\
n \\
n\end{array}$ & 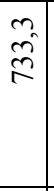 & $\begin{array}{l}0 \\
0 \\
0 \\
0\end{array}$ & $\begin{array}{l}m \\
m \\
m\end{array}$ & 1 & \begin{tabular}{l|} 
\\
$\stackrel{0}{0}$ \\
$\stackrel{\infty}{0}$
\end{tabular} & 1 \\
\hline & & 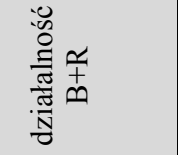 & $\nabla$ & $\nabla^{+}$ & $\begin{array}{l}0 \\
0 \\
=\end{array}$ & $\stackrel{m}{\stackrel{2}{2}}$ & \begin{tabular}{l}
$\infty$ \\
$\varnothing$ \\
\hdashline \\
$n$
\end{tabular} & $\hat{\vec{\lambda}}$ & $\begin{array}{l}n \\
6 \\
f\end{array}$ & $\frac{\vec{z}}{\dot{\Xi}}$ & $\hat{\tilde{N}}$ & $\stackrel{2}{2}$ & $\hat{\hat{0}}$ & $\vec{a}$ & \begin{tabular}{l}
$n$ \\
\multirow{r}{r}{}
\end{tabular} & $\begin{array}{c}0 \\
i \\
\\
=\end{array}$ & $\begin{array}{l}0 \\
\stackrel{0}{0}\end{array}$ & $\stackrel{0}{i}$ \\
\hline & & $\begin{array}{l}\overline{0} \\
\frac{0}{0} \\
0 \\
0\end{array}$ & $m$ & $\begin{array}{l}0 \\
0 \\
0 \\
0\end{array}$ & $\begin{array}{l} \\
\therefore \\
R\end{array}$ & $\stackrel{1}{0}$ & $\begin{array}{l}\hat{\sigma} \\
\hat{n}\end{array}$ & $\overrightarrow{\stackrel{d}{d}}$ & ñ & $\begin{array}{l}\stackrel{a}{ } \\
\infty \\
=\end{array}$ & \begin{tabular}{|l|}
$n$ \\
0 \\
0 \\
0
\end{tabular} & $\vec{a}$ & 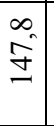 & $\vec{\infty}$ & $\begin{array}{c}0 \\
y \\
\pm \\
\pm\end{array}$ & $\begin{array}{l}\sigma_{0} \\
\sigma_{0}^{\prime}\end{array}$ & $\begin{array}{l} \\
\infty \\
\infty\end{array}$ & $\begin{array}{l}0 \\
\text { ปे }\end{array}$ \\
\hline & & $\frac{\ddot{\theta}}{\frac{\theta}{\Xi}}$ & $\sim$ & 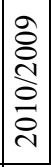 & 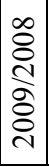 & 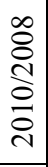 & 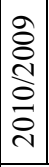 & 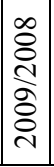 & 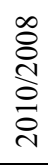 & 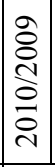 & 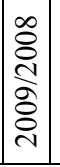 & 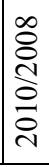 & 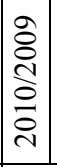 & 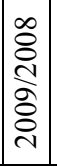 & 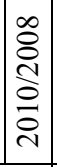 & 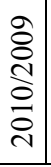 & 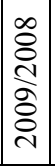 & 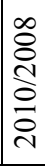 \\
\hline & & 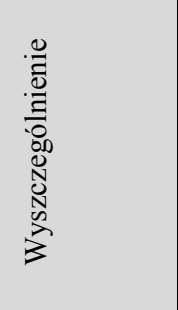 & -1 & & $\begin{array}{l}\text { E. } \\
\frac{0}{0} \\
0 \\
0\end{array}$ & & 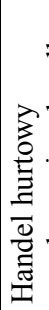 & 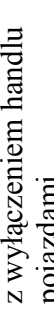 & 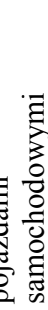 & & 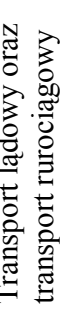 & & & 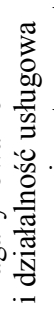 & 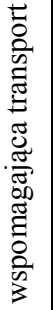 & & 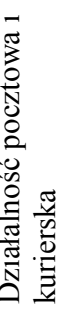 & \\
\hline
\end{tabular}




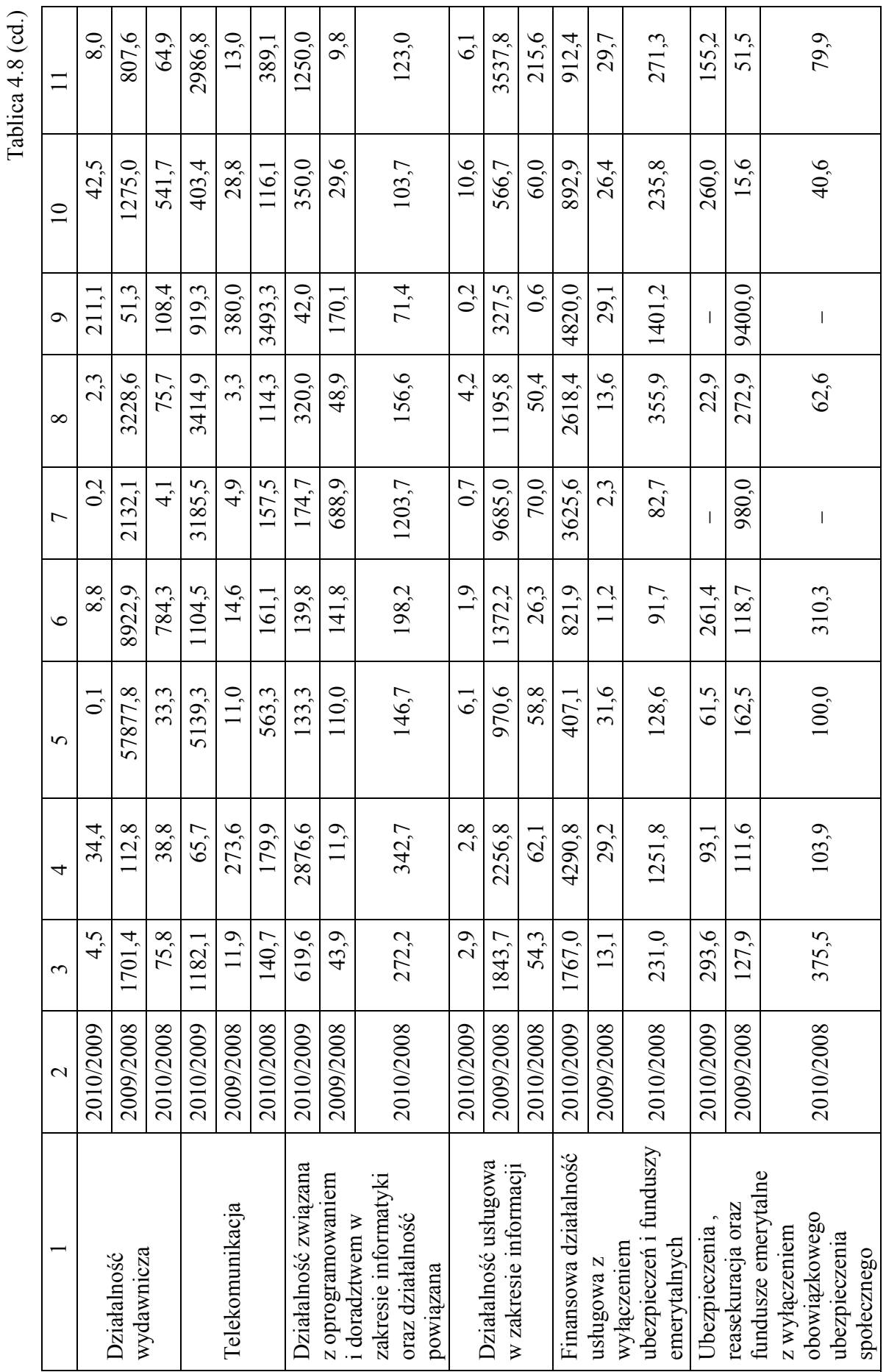




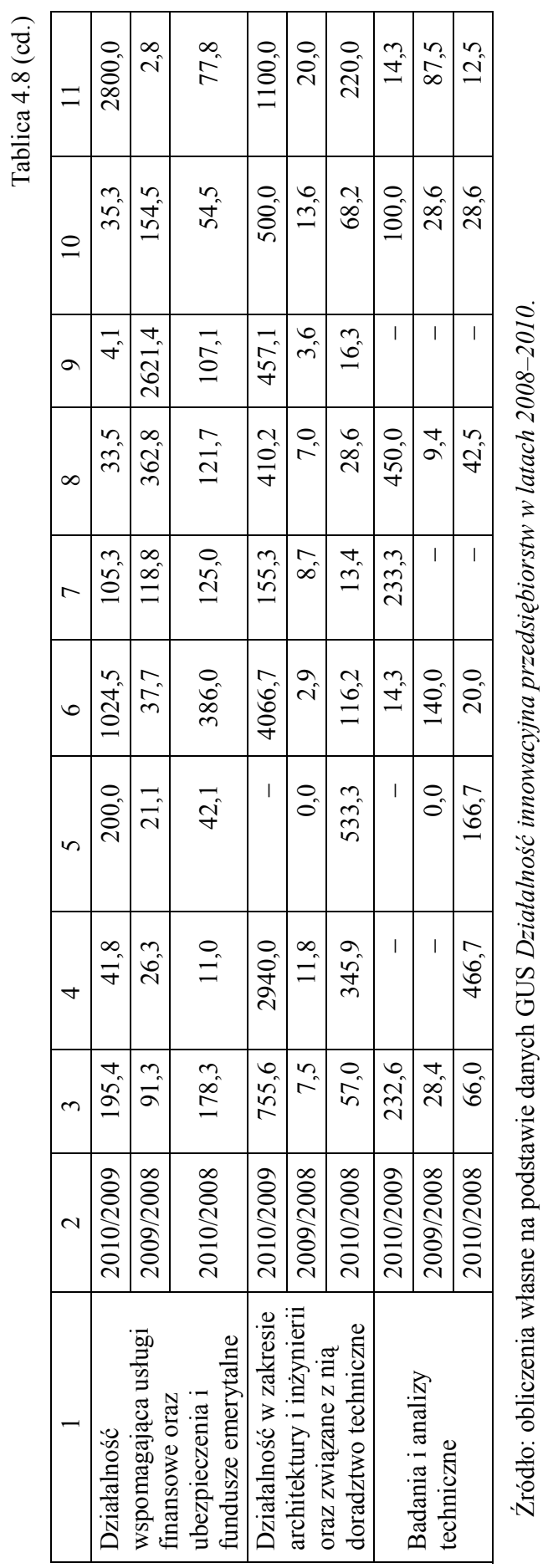


W roku 2010 najwyższe nakłady na działalność innowacyjną, wynoszące ponad połowę wszystkich nakładów, poniosły przedsiębiorstwa zaklasyfikowane do działów 58, 61-63.

Proponowanym przez Podręcznik Oslo wskaźnikiem służącym do oceny efektów działalności innowacyjnej przedsiębiorstw jest udział w badanym roku przychodów ze sprzedaży produktów nowych lub istotnie ulepszonych, wprowadzonych na rynek w ciagu ostatnich trzech lat, w wartości przychodów ogółem. Sprzedaż produktów nowych i istotnie ulepszonych bada się także w podziale na sprzedaż (Działalność... 2008):

- produktów nowych lub istotnie ulepszonych z punktu widzenia rynku, na którym działa przedsiębiorstwo, które zostały wprowadzone na rynek w okresie trzech ostatnich lat;

- produktów nowych lub istotnie ulepszonych tylko z punktu widzenia przedsiębiorstwa, które zostały wprowadzone na rynek w okresie trzech ostatnich lat.

Udział przychodów netto ze sprzedaży produktów nowych lub istotnie ulepszonych wprowadzonych na rynek w latach 2008-2010 w przychodach ze sprzedaży ogółem w 2010 r. w przedsiębiorstwach przemysłowych wyniósł $11,3 \%$, natomiast $\mathrm{w}$ przedsiębiorstwach $\mathrm{z}$ sektora usług $-4,1 \%$. W tab. 4.12 przedstawiono udział przychodów ze sprzedaży produktów nowych lub istotnie ulepszonych wprowadzonych na rynek w przychodzie ogółem.

Tablica 4.12. Udział przychodów ze sprzedaży produktów wprowadzonych na rynek w przychodach ze sprzedaży ogółem w sektorze usług według wielkości przedsiębiorstw

\begin{tabular}{|l|c|c|c|c|c|c|}
\hline \multirow{2}{*}{$\begin{array}{c}\text { Liczba } \\
\text { pracujących }\end{array}$} & \multicolumn{6}{|c|}{ Produkty wprowadzone na rynek w \% sprzedaży ogółem } \\
\cline { 2 - 7 } & ogółem & $\begin{array}{c}\text { ogółem } \\
2010\end{array}$ & $\begin{array}{c}\text { nowe dla } \\
\text { rynku } \\
2008\end{array}$ & $\begin{array}{c}\text { nowe dla } \\
\text { rynku } \\
2010\end{array}$ & $\begin{array}{c}\text { nowe tylko dla } \\
\text { przedsiębiorstwa } \\
2008\end{array}$ & $\begin{array}{c}\text { nowe tylko dla } \\
\text { przedsiębiorstwa } \\
2010\end{array}$ \\
\hline Ogółem & 6,4 & 4,1 & 1,9 & 1,6 & 4,5 & 2,5 \\
\hline $10-49$ & 2,7 & 1,6 & 1,8 & 0,5 & 0,9 & 1,1 \\
\hline $50-249$ & 6,5 & 2,3 & 1,7 & 1,3 & 4,8 & 1,0 \\
\hline Powyżej 249 & 9,2 & 7,0 & 2,1 & 2,5 & 7,1 & 4,5 \\
\hline
\end{tabular}

Źródło: opracowanie własne na podstawie GUS Działalność innowacyjna przedsiębiorstw w latach 2008-2010, (2011) oraz Dziatalność innowacyjna przedsiębiorstw w latach 2006-2009 (2010).

Pomimo ogólnych oczekiwań udział sprzedaży produktów innowacyjnych w roku 2010 okazał się mniejszy niż w 2008 r., niemniej jednak rósł wraz ze wzrostem wielkości przedsiębiorstw, przy czym wzrost ten był znacznie większy w przypadku przedsiębiorstw przemysłowych. 


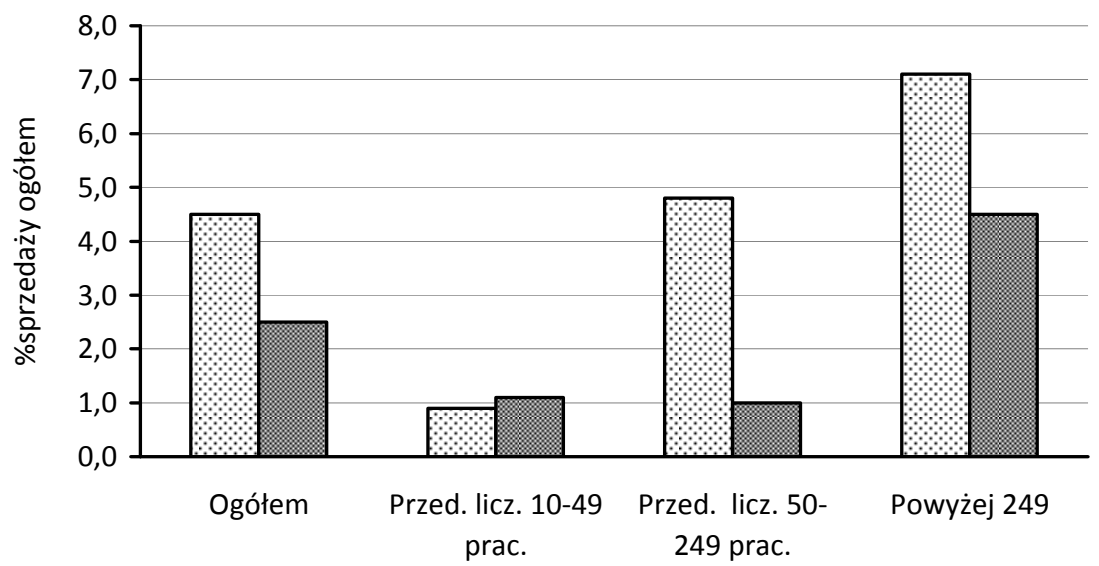

Đnowe tylko dla przedsiębiorstwa 2008

nowe tylko dla przedsiębiorstwa 2010

Rys. 4.5. Przychody ze sprzedaży produktów nowych lub istotnie ulepszonych wprowadzonych na rynek - nowe tylko dla przedsiębiorstw

Źródło: opracowanie własne na podstawie GUS Działalność innowacyjna przedsiębiorstw w latach 2008-2010 (2011) oraz Dziatalność innowacyjna przedsiębiorstw w latach 2006-2009 (2010).

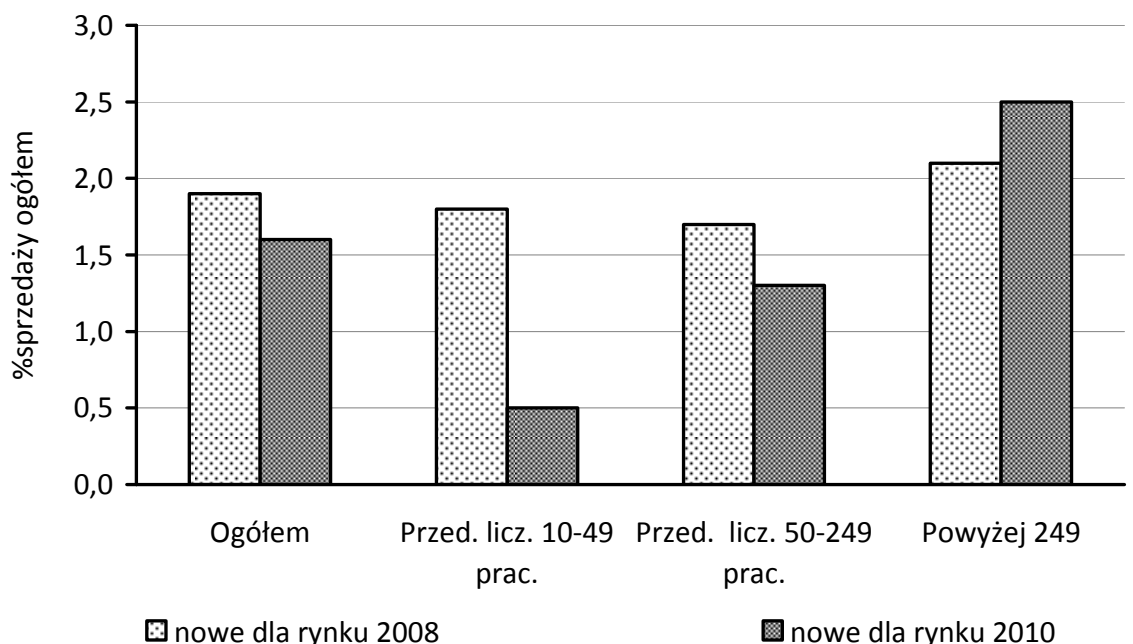

Rys. 4.6. Przychody ze sprzedaży produktów nowych lub istotnie ulepszonych wprowadzonych na rynek - produkty nowe dla rynku

Źródło: opracowanie własne na podstawie GUS Działalność innowacyjna przedsiębiorstw w latach 2008-2010 (2011) oraz Działalność innowacyjna przedsiębiorstw w latach 2006-2009 (2010). 


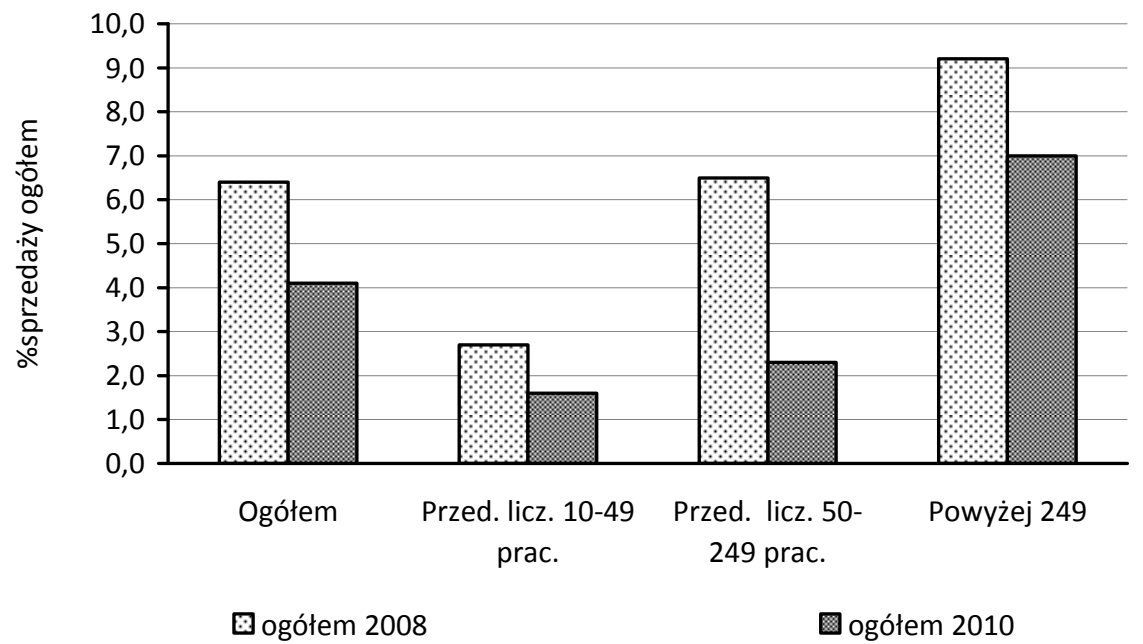

Rys. 4.7. Przychody ze sprzedaży produktów nowych lub istotnie ulepszonych wprowadzonych na rynek - produkty wprowadzone na rynek - ogółem

Źródło: opracowanie własne na podstawie GUS Działalność innowacyjna przedsiębiorstw w latach 2008-2010 (2011) oraz Działalność innowacyjna przedsiębiorstw w latach 2006-2009 (2010).

W tab. 4.13 przedstawiono przychody ze sprzedaży produktów nowych lub istotnie ulepszonych w roku 2008 i 2010, uzyskanych z wprowadzonych na rynek produktów w latach 2006-2008 oraz 2008-2010 z podziałem na województwa.

Tablica 4.13. Przychody ze sprzedaży produktów nowych lub istotnie ulepszonych w przedsiębiorstwach usługowych według województw w 2008 i 2010 r. w \% sprzedaży ogółem

\begin{tabular}{|c|c|c|c|c|c|c|}
\hline \multirow[b]{2}{*}{$\begin{array}{c}\text { Nazwa } \\
\text { województwa }\end{array}$} & \multicolumn{3}{|c|}{$\begin{array}{l}\text { Produkty wprowadzone na rynek w } \\
\text { latach } 2006-2008\end{array}$} & \multicolumn{3}{|c|}{$\begin{array}{c}\text { Produkty wprowadzone na rynek } \\
\text { w latach } 2008-2010\end{array}$} \\
\hline & $\begin{array}{l}\text { ogółem } \\
2008\end{array}$ & $\begin{array}{l}\text { nowe tylko } \\
\text { dla przed- } \\
\text { siębiorstwa } \\
2008\end{array}$ & $\begin{array}{l}\text { nowe dla } \\
\text { rynku } 2008\end{array}$ & $\begin{array}{l}\text { ogółem } \\
2010\end{array}$ & $\begin{array}{l}\text { nowe dla } \\
\text { rynku } 2010\end{array}$ & \begin{tabular}{|c|} 
nowe tylko \\
dla przed- \\
siębiorstwa \\
2010
\end{tabular} \\
\hline 1 & 2 & 3 & 4 & 5 & 6 & 7 \\
\hline Polska & 6,4 & 4,5 & 1,9 & 4,1 & 1,6 & 2,5 \\
\hline Dolnośląskie & 8,7 & 4,6 & 4 & 2,8 & 2,1 & 0,7 \\
\hline $\begin{array}{l}\text { Kujawsko- } \\
\text { pomorskie }\end{array}$ & 1,4 & 0,5 & 0,9 & 0,5 & 0,1 & 0,3 \\
\hline Lubelskie & 0,5 & 0,3 & 0,1 & 17,4 & 0,4 & 17 \\
\hline Lubuskie & 1,3 & 1 & 0,2 & 0,8 & 0,6 & 0,1 \\
\hline Łódzkie & 2,4 & 1,2 & 1,2 & 1,1 & 0,6 & 0,5 \\
\hline
\end{tabular}


Tablica 4.13 (cd.)

\begin{tabular}{|l|c|c|c|c|c|c|}
\hline \multicolumn{1}{|c|}{1} & 2 & 3 & 4 & 5 & 6 & 7 \\
\hline Małopolskie & 3,1 & 0,1 & 3 & 1,1 & 0,6 & 0,4 \\
\hline Mazowieckie & 10,3 & 8,2 & 2,1 & 6,5 & 2,6 & 3,8 \\
\hline Opolskie & 0,7 & 0,3 & 0,5 & 0,6 & 0,5 & 0,1 \\
\hline Podkarpackie & 5,3 & 5 & 0,3 & 0,7 & 0,2 & 0,4 \\
\hline Podlaskie & 0,3 & 0,1 & 0,2 & 0,3 & 0,1 & 0,2 \\
\hline Pomorskie & 3,4 & 1,9 & 1,5 & 2,4 & 0,7 & 1,7 \\
\hline Śląskie & 2 & 0,9 & 1,1 & 1,1 & 0,7 & 0,4 \\
\hline Świętokrzyskie & 1,8 & 1,4 & 0,4 & 0,6 & 0 & 0,6 \\
\hline $\begin{array}{l}\text { Warmińsko- } \\
\text { mazowieckie }\end{array}$ & 2 & 0,2 & 1,8 & 0,9 & 0,4 & 0,4 \\
\hline Wielkopolskie & 3,2 & 0,7 & 2,4 & 1,2 & 0,8 & 0,4 \\
\hline $\begin{array}{l}\text { Zachodniopomor- } \\
\text { skie }\end{array}$ & 1 & 0,2 & 0,8 & 1,3 & 0,5 & 0,8 \\
\hline
\end{tabular}

Źródło: opracowanie własne na podstawie GUS Działalność innowacyjna przedsiębiorstw w latach 2006-2009 (2010), Działalność innowacyjna przedsiębiorstw w latach 2008-2010 (2011).

W roku 2010 najwyższy udział przychodów ze sprzedaży produktów nowych lub istotnie ulepszonych w wartości przychodów ogółem osiagnęło województwo lubelskie - 17,4\%, na drugim miejscu plasowało się województwo mazowieckie 6,5\%, najniższa wartość wystapiła w województwie podlaskim - 0,3\% (rys. 4.5).

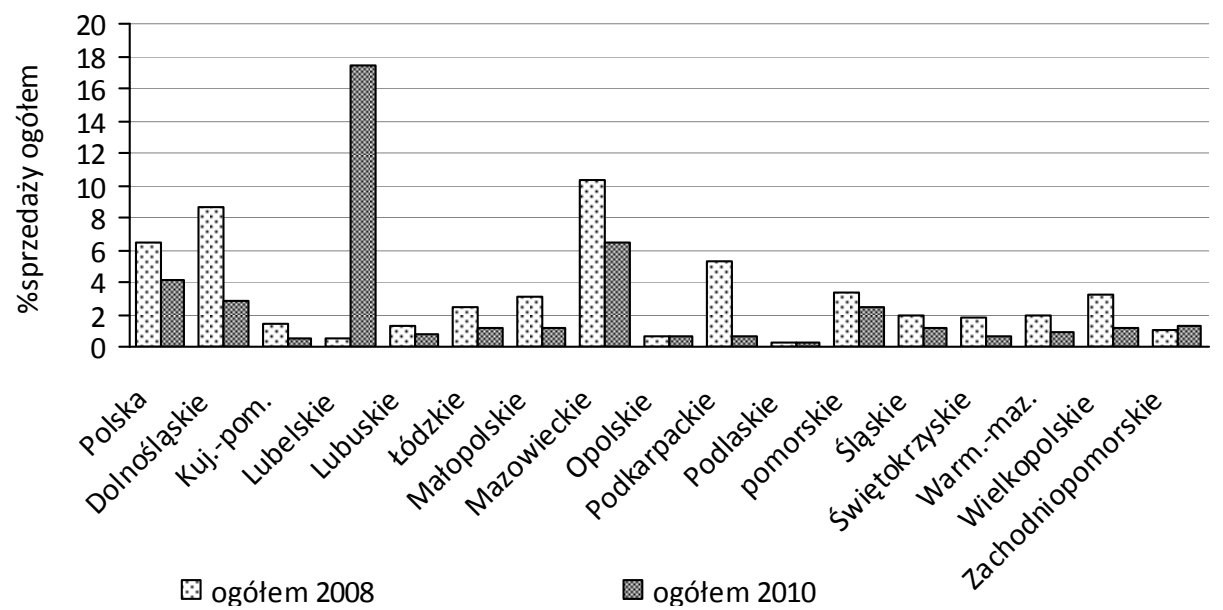

Rys. 4.8. Przychody ze sprzedaży produktów w sektorze usług według województw w roku 2008 i 2010

Źródło: opracowanie własne na podstawie GUS Działalność innowacyjna przedsiębiorstw w latach 2008-2010, (2011) oraz Działalność innowacyjna przedsiębiorstw w latach 2006-2009 (2010). 


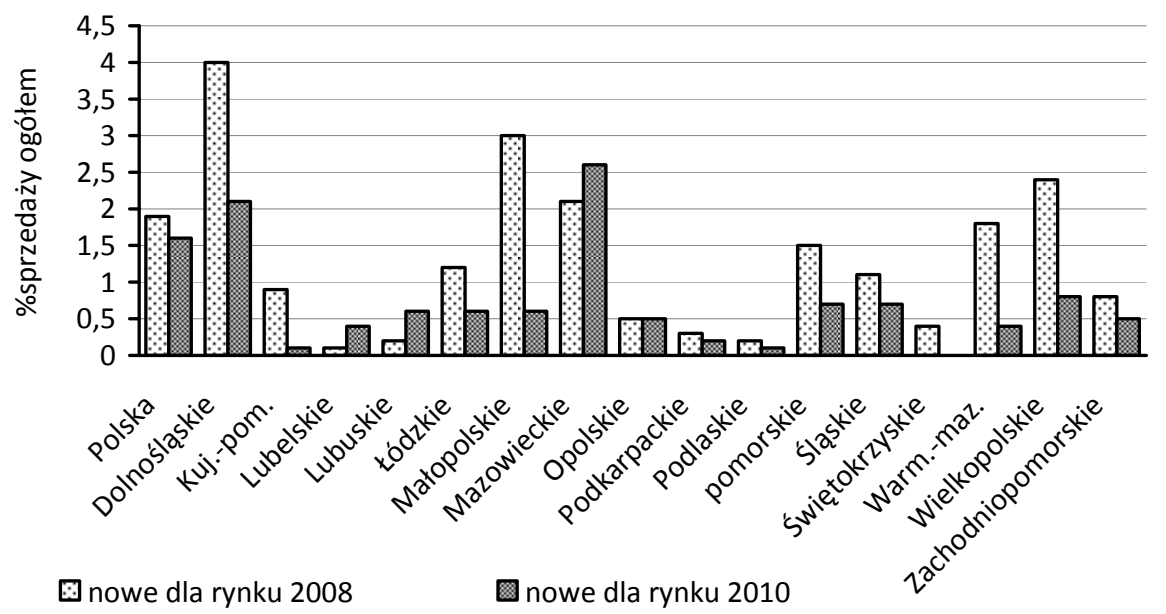

Rys. 4.9. Przychody ze sprzedaży produktów w sektorze usług według województw w roku 2008 i 2010 - produkty nowe dla rynku

Źródło: opracowanie własne na podstawie GUS Działalność innowacyjna przedsiębiorstw w latach 2008-2010, (2011) oraz Działalność innowacyjna przedsiębiorstw w latach 2006-2009 (2010).

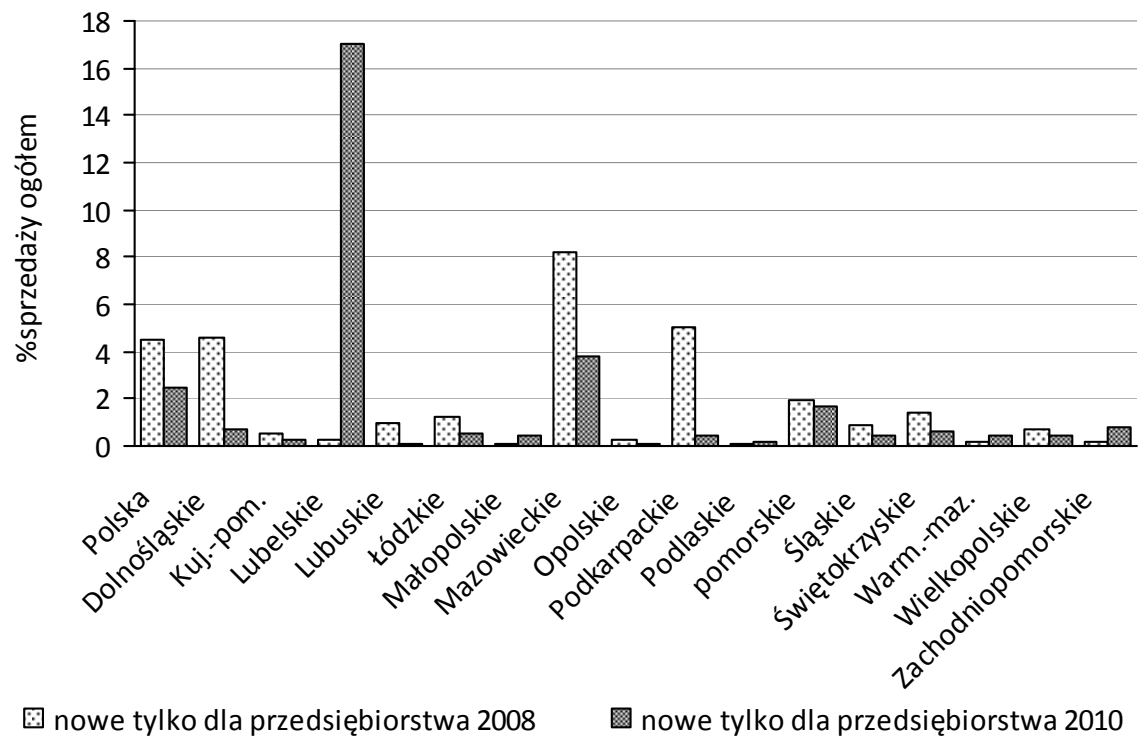

Rys. 4.10. Przychody ze sprzedaży produktów w sektorze usług według województw w roku 2008 i 2010 - produkty nowe dla przedsiębiorstw

Źródło: opracowanie własne na podstawie GUS Działalność innowacyjna przedsiębiorstw w latach 2008-2010 (2011) oraz Dziatalność innowacyjna przedsiębiorstw w latach 2006-2009 (2010). 
$\mathrm{W}$ tab. 4.14. prezentowane są przychody ze sprzedaży produktów nowych lub istotnie ulepszonych uwzględniające działy PKD. Najwyższe wartości zarówno w 2008, jak i 2010 r. osiagnął dział ubezpieczenia, reasekuracja oraz fundusze emerytalne, z wyłączeniem obowiązkowego ubezpieczenia społecznego, oraz telekomunikacja, przy czym korzystniejsze wartości osiagnięto $\mathrm{w}$ roku 2008 .

Tablica 4.14. Przychody ze sprzedaży produktów nowych lub istotnie ulepszonych w przedsiębiorstwach z sektora usług według działów PKD w 2008 i 2010 r.

w \% sprzedaży ogółem

\begin{tabular}{|c|c|c|c|c|c|c|}
\hline \multirow[b]{2}{*}{ Wyszczególnienie } & \multicolumn{3}{|c|}{$\begin{array}{l}\text { Produkty wprowadzone na } \\
\text { rynek w latach 2006-2008 }\end{array}$} & \multicolumn{3}{|c|}{$\begin{array}{l}\text { Produkty wprowadzone na } \\
\text { rynek w latach 2008-2010 }\end{array}$} \\
\hline & $\begin{array}{l}\text { ogółem } \\
2008\end{array}$ & $\begin{array}{l}\text { nowe } \\
\text { dla } \\
\text { rynku } \\
2008\end{array}$ & $\begin{array}{l}\text { nowe tylko } \\
\text { dla przed- } \\
\text { siębiorstwa } \\
2008\end{array}$ & $\begin{array}{l}\text { ogółem } \\
2010\end{array}$ & $\begin{array}{l}\text { nowe } \\
\text { dla } \\
\text { rynku } \\
2010\end{array}$ & $\begin{array}{l}\text { nowe tylko } \\
\text { dla przed- } \\
\text { siębiorstwa } \\
2010\end{array}$ \\
\hline 1 & 2 & 3 & 4 & 5 & 6 & 7 \\
\hline Ogółem & 6,4 & 1,9 & 4,5 & 4,1 & 1,6 & 2,5 \\
\hline $\begin{array}{l}\text { Handel hurtowy, } \mathrm{z} \text { wyłączeniem } \\
\text { handlu pojazdami samochodo- } \\
\text { wymi }\end{array}$ & 1,9 & 1,2 & 0,7 & 1,6 & 0,4 & 1,2 \\
\hline $\begin{array}{l}\text { Transport lądowy oraz rurocią- } \\
\text { gowy }\end{array}$ & 4,2 & 2,1 & 2,1 & 2 & 0,9 & 1,1 \\
\hline Transport lotniczy & 0,7 & 0 & 0,7 & 5,9 & 2,7 & 3,2 \\
\hline $\begin{array}{l}\text { Magazynowanie i działalność } \\
\text { usługowa wspomagająca trans- } \\
\text { port }\end{array}$ & 2,9 & 1,7 & 1,2 & 12,1 & 10,1 & 2 \\
\hline $\begin{array}{l}\text { Działalność pocztowa } \\
\text { i kurierska }\end{array}$ & 25,0 & 1,4 & 23,6 & 1,6 & 1,5 & 0,0 \\
\hline Działalność wydawnicza & 12,3 & 10,1 & 2,1 & 3,3 & 2,8 & 0,5 \\
\hline Telekomunikacja & 33,8 & 3,2 & 30,6 & 15,9 & 4,8 & 11,1 \\
\hline $\begin{array}{l}\text { Działalność związana z opro- } \\
\text { gramowaniem i doradztwem w } \\
\text { zakresie informatyki oraz dzia- } \\
\text { łalność powiązana }\end{array}$ & 12,6 & 8 & 4,6 & 7,2 & 5,1 & 2,1 \\
\hline $\begin{array}{l}\text { Działalność usługowa w zakre- } \\
\text { sie informacji }\end{array}$ & 13,2 & 10,2 & 3,1 & 9,7 & 5,8 & 3,9 \\
\hline $\begin{array}{l}\text { Finansowa działalność usługowa } \\
\text { z wyłączeniem ubezpieczeń i } \\
\text { funduszy emerytalnych }\end{array}$ & 3,2 & 1,6 & 1,6 & 3,8 & 2,1 & 1,7 \\
\hline $\begin{array}{l}\text { Ubezpieczenia, reasekuracja } \\
\text { oraz fundusze emerytalne, z } \\
\text { wyłączeniem obowiązkowego } \\
\text { ubezpieczenia społecznego }\end{array}$ & 29,3 & 4,8 & 24,5 & 18,9 & 5,7 & 13,2 \\
\hline
\end{tabular}


Tablica 4.14 (cd.)

\begin{tabular}{|l|r|r|r|r|r|r|}
\hline \multicolumn{1}{|c|}{1} & 2 & 3 & 4 & 5 & 6 & 7 \\
\hline $\begin{array}{l}\text { Działalność wspomagająca } \\
\text { usługi finansowe oraz ubezpie- } \\
\text { czenia i fundusze emerytalne }\end{array}$ & 5,5 & 2,7 & 2,8 & 2,7 & 0,7 & 2,0 \\
\hline $\begin{array}{l}\text { Działalność w zakresie architek- } \\
\text { tury i inżynierii oraz związane z } \\
\text { nią doradztwo techniczne }\end{array}$ & 2,7 & 2,4 & 0,3 & 2,3 & 1,2 & 1,1 \\
\hline Badania i analizy techniczne & 8,8 & 4,1 & 4,7 & 0,9 & 0,3 & 0,6 \\
\hline
\end{tabular}

Źródło: opracowanie własne na podstawie GUS Działalność innowacyjna przedsiębiorstw w latach 2006-2009 (2010), Działalność innowacyjna przedsiębiorstw w latach 2008-2010 (2011).

W 2010 r. przeważająca część przychodów (59,5\%) uzyskana została ze sprzedaży produktów zaliczanych do usług opartych na wiedzy.
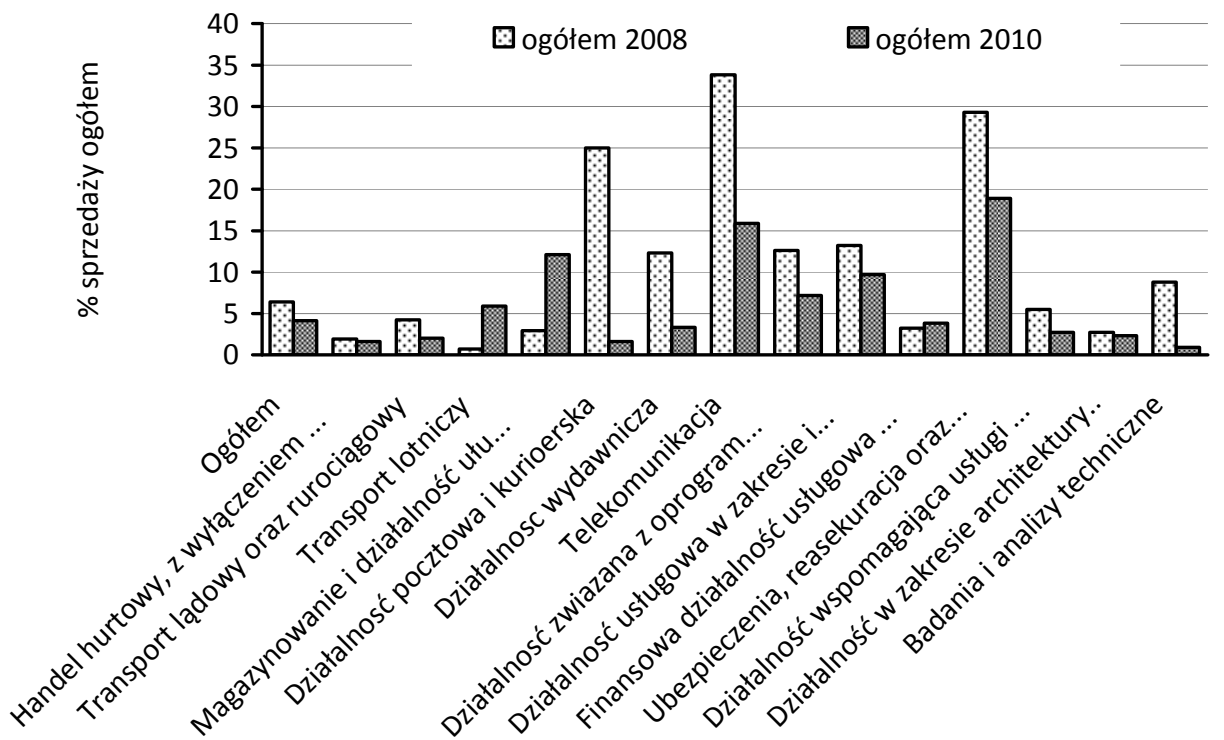

Rys. 4.10. Przychody ze sprzedaży produktów nowych lub istotnie ulepszonych według działów PKD

Źródło: opracowanie własne na podstawie GUS Działalność innowacyjna przedsiębiorstw w latach 2006-2009 (2010), Działalność innowacyjna przedsiębiorstw w latach 2008-2010 (2011). 

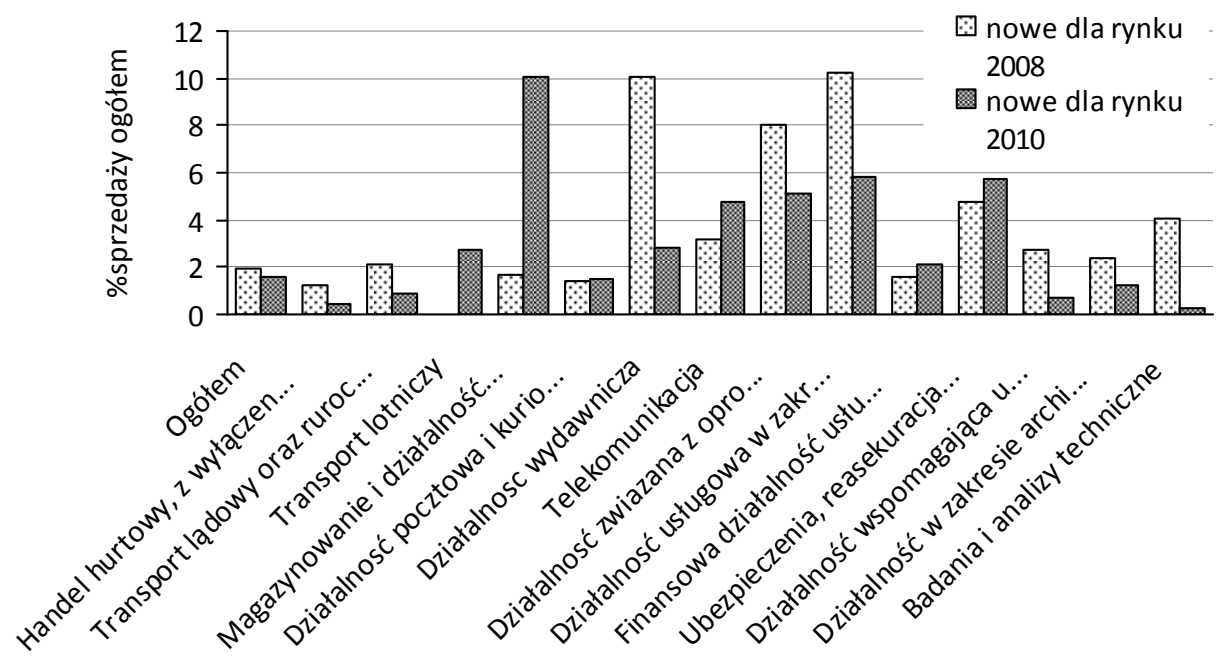

Rys. 4.12. Przychody ze sprzedaży produktów nowych dla rynku $\mathrm{z}$ uwzględnieniem działów PKD

Źródło: opracowanie własne na podstawie GUS Działalność innowacyjna przedsiębiorstw w latach 2006-2009 (2010), Dziatalność innowacyjna przedsiębiorstw w latach 2008-2010 (2011).
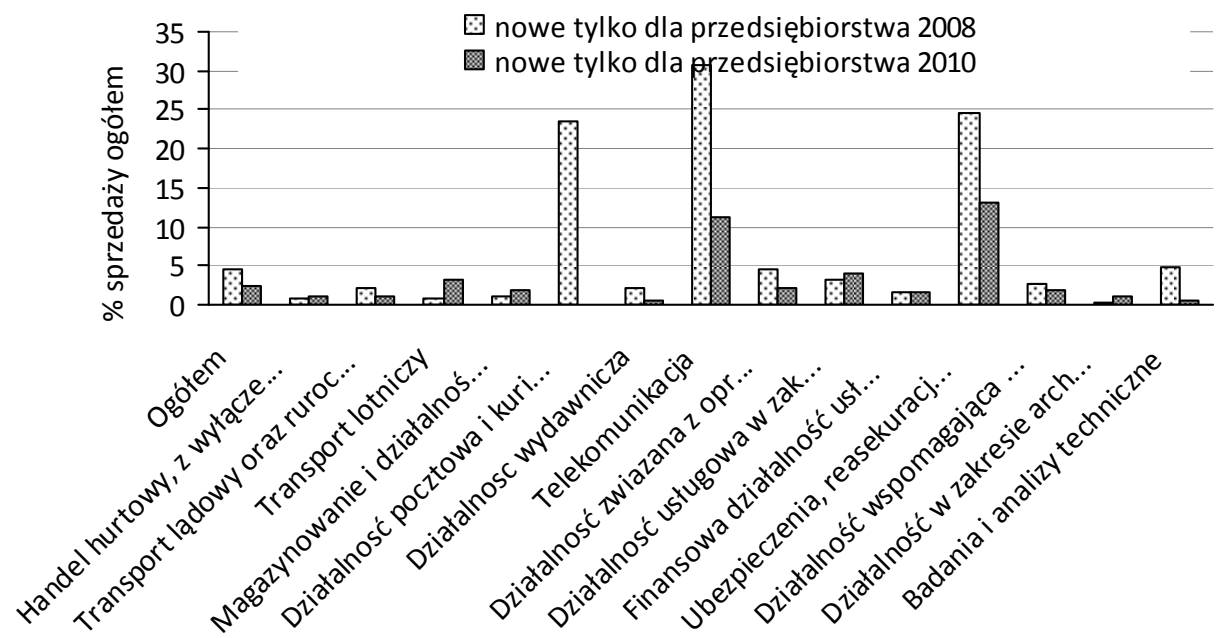

Rys. 4.13. Przychody ze sprzedaży według działów PKD

- produkty nowe tylko dla przedsiębiorstwa

Źródło: opracowanie własne na podstawie GUS Działalność innowacyjna przedsiębiorstw w latach 2006-2009 (2010), Działalność innowacyjna przedsiębiorstw w latach 2008-2010 (2011). 


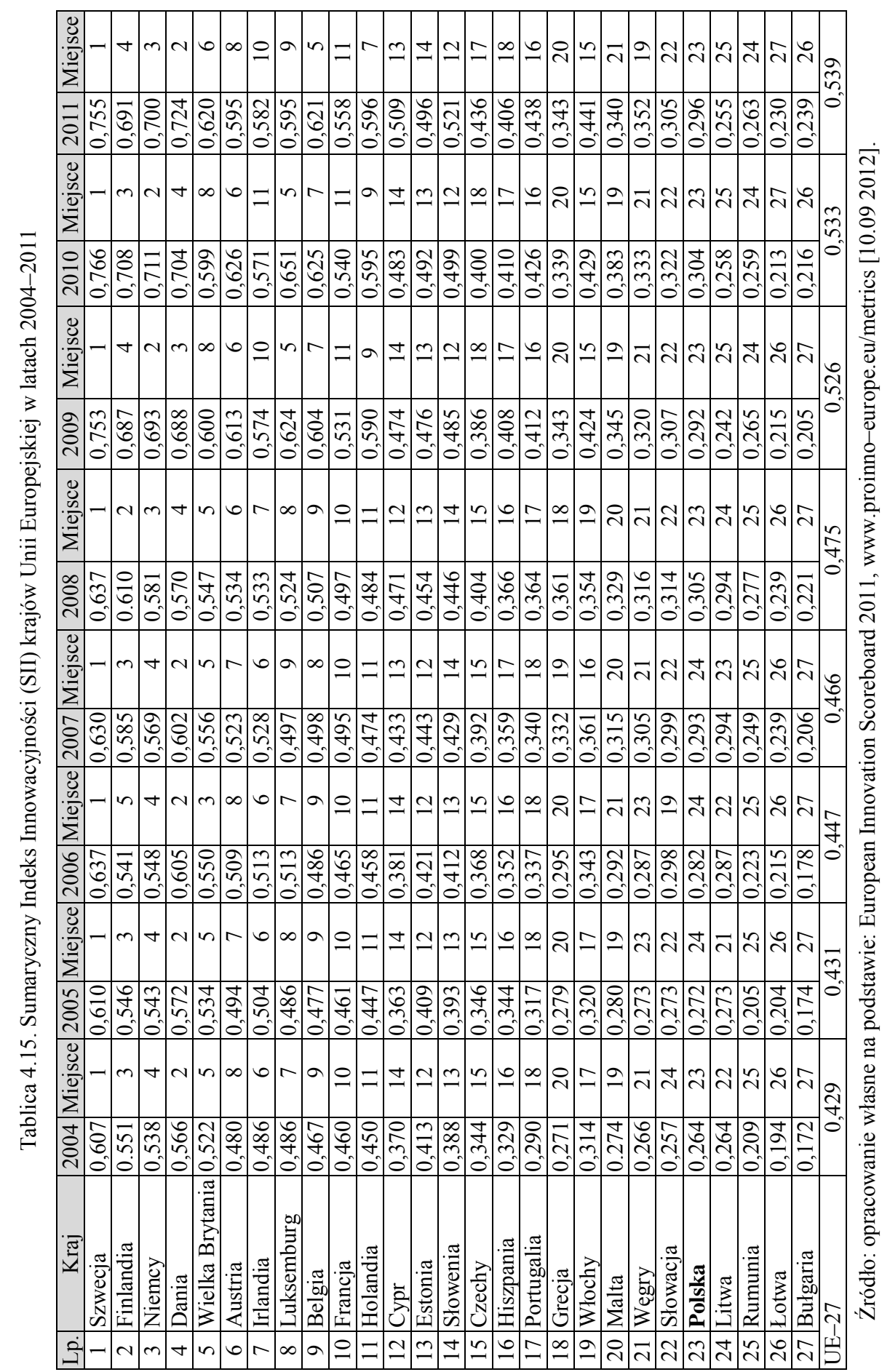


Oceny innowacyjności polskiej gospodarki możemy także dokonać na podstawie sumarycznego indeksu innowacyjności, który jest średnia arytmetyczną, liczoną na podstawie 29 wskaźników cząstkowych dla 27 krajów Unii Europejskiej oraz Chorwacji, Turcji, Islandii, Norwegii, Szwajcarii oraz Japonii. Sumaryczny Indeks Innowacyjności (SII) przyjmuje wartości z przedziału od 0 do 1 , wartość bliższa jedynce świadczy o wyższym poziomie innowacyjności danego kraju. W tab. 4.15 przedstawiono wartości wskaźnika SII w latach 2004-2011 i pozycje państw Unii Europejskiej pod względem poziomu innowacyjności.

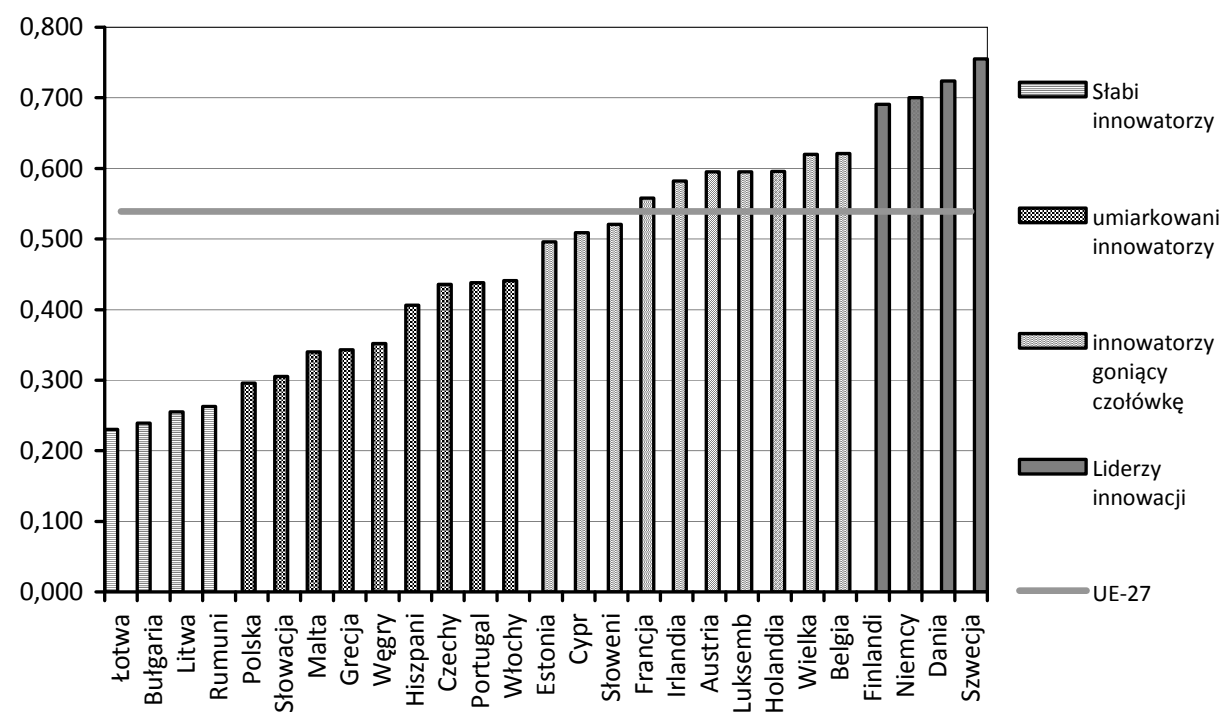

Rys. 4.14. Poziom innowacyjności państw Unii Europejskiej

Źródło: opracowanie własne na podstawie :European Innovation Scoreboard 2011, www.proinno-europe.eu/metrics [10.09 2012].

Wskaźnik SII ujawnia wyraźne różnice w poziomie innowacyjności państw Unii Europejskiej. W roku 2011 wartości indeksu SII mieściły się w przedziale od 0,239 do 0,755. Liderami UE w zakresie innowacyjności w 2011 r. były: Szwecja, Finlandia, Dania, Niemcy i Wielka Brytania. Polska z wartością wskaźnika dla 2011 r. równą 0,29 znajdowała się na 23. pozycji. Niższe wartości od Polski uzyskały jedynie: Litwa, Łotwa, Rumunia i Bułgaria. Porównanie wartości indeksu SII dla Polski i państw Unii Europejskiej potwierdziło przypuszczenie o znacznym dystansie dzielącym nas od państw UE. Pomimo niekorzystnych wyników SII w analizowanym okresie zarówno dla Polski, jak i wielu innych państw nie zaobserwowano znacznych zmian pozycji w rankingu. Brak 
znacznych spadków w pozycjach określonych na podstawie SII wśród państw „słabszych” w okresie panującego kryzysu można także odczytywać jako dobrą wiadomość. Analiza danych charakteryzujących proces innowacyjności sektora usług pomimo wszystko pozwala stwierdzić, że sektor usług w Polsce, napotykając na liczne bariery, staje się coraz bardziej innowacyjny i wykazuje znaczne zainteresowanie działalnością B+R. Przyczyn niskiego poziomu innowacyjności polskich przedsiębiorstw należy upatrywać w złej sytuacji finansowej wielu przedsiębiorstw oraz obawie przed niepowodzeniem.

O słuszności wprowadzania innowacji i ponoszenia nakładów innowacyjnych świadczy wiele czynników, wśród których można wymienić wielkość sprzedaży czy dochód, niemniej jednak wiele przedsiębiorstw w okresie swej działalności napotyka na pewnego rodzaju bariery i ograniczenia. Zaliczyć do nich można (Kierunki zwiększania... 2006):

- wysokie koszty opracowania i wdrażania innowacji,

- niewystarczająco rozwiniętą infrastrukturę komercjalizacji wyników prac $\mathrm{B}+\mathrm{R}$,

- wysokie ryzyko inwestowania w nowe technologie,

- brak kapitału na tworzenie i rozwój przedsiębiorstw innowacyjnych.

Wzrost innowacyjności sektora usług, jak i całej gospodarki zależy od wielu czynników. Kasperkiewicz (2011) za kluczowe w kształtowaniu gospodarki opartej na wiedzy i podniesieniu poziomu innowacyjności uznaje sformułowanie długookresowej strategii rozwoju społeczno-gospodarczego. Zwraca także uwagę na zapewnienie stabilnego otoczenia makroekonomicznego, będącego podstawą realizacji programów modernizacyjnych. Za istotne czynniki w procesie rozwoju innowacyjności uznaje się również wykwalifikowany kapitał ludzki oraz nakłady na $\mathrm{B}+\mathrm{R}$. Wzrost nakładów i odpowiednia ich alokacja na działalność $\mathrm{B}+\mathrm{R}$ są warunkiem utworzenia efektywnego systemu wspierania innowacji. $Z$ kolei dla efektywnego funkcjonowania systemu innowacji konieczna jest stała i owocna współpraca pomiędzy podmiotami sfery $\mathrm{B}+\mathrm{R}$ a przedsiębiorstwami (Kasperkiewicz 2011, s. 86). Istotne jest także dążenie do poprawy jakości zarządzania przedsiębiorstwami i podnoszenie konkurencyjności mikroekonomicznej. Ważnym czynnikiem, mającym wpływ na innowacyjność sektora usług, jest również zdolność przedsiębiorstwa do tworzenia, pozyskiwania i zarządzania wiedzą. Innowacyjność sektora usług wpływa na rozwój gospodarczy kraju.

W celu osiagnięcia odpowiedniego poziomu rozwoju należy się skoncentrować na czterech kierunkach rozwoju:

- wykorzystaniu nowych technologii w celu zwiększenia konkurencyjności głównych sektorów gospodarki,

- tworzeniu nowych innowacyjnych przedsiębiorstw wykorzystujących nowoczesne technologie, 
- stymulowaniu rozwoju współpracy pomiędzy przedsiębiorstwami oraz firmami i instytucjami otoczenia biznesu w zakresie innowacyjności,

- motywowaniu przedsiębiorstw do prowadzenia i korzystania z wyników prac ośrodków badawczych.

Polska gospodarka w porównaniu z krajami wysoko rozwiniętymi nie jest gospodarką opartą na wiedzy, nie osiągnęła także odpowiedniego poziomu rozwoju sektorów uważanych za jej nośniki (edukacji, B+R, działów opartych na wysokiej technologii). Poza tym poziom nakładów na B+R w stosunku do PKB w Polsce jest znacznie poniżej średniej dla Unii; średnia dla UE-27 dla roku 2010 wyniosła 2,0\%, a dla Polski $0,74 \%$. Strategia „Europa 2020” podkreśla, że osiagnięcie silnej, inteligentnej i zrównoważonej gospodarki Unii Europejskiej jest możliwe między innymi poprzez osiagnnięcie do 2020 r. nakładów na badania i rozwój wynoszących 3\% PKB Unii. Wydatki na badania i rozwój w Polsce w latach 1995-2003 średnio wynosiły 0,63\% PKB, w latach 2004-2009 stanowiły $0,59 \%$ PKB, w roku $2010-0,74 \%$ PKB. Średnia dla Unii w 2010 r. stanowiła 2\% PKB, co Polsce daje 20. miejsce. Wśród krajów Unii Europejskiej (Forbes 2012) liderami innowacji są Dania (6\% PKB wydatków publicznych i 3,7\% prywatnych na badania i rozwój), Niemcy (w sumie 6,4\% PKB) oraz Finlandia i Szwecja (w sumie ok. 3,4\%). Dobre miejsce zajmuje: Belgia, Wielka Brytania, Holandia, Austria, Luksemburg, Irlandia, Francja, Słowenia, Cypr i Estonia $z$ wynikami zbliżonymi do średniej dla całej UE (2\% PKB). Poniżej średniej z wydatkami na badania poza Polską (wydatki publiczne 0,53\% PKB, prywatne $0,2 \%$ PKB) utrzymują się Włochy, Portugalia, Czechy, Hiszpania, Węgry, Grecja, Malta, Słowacja. Na ostatnich pozycjach znajduje się: Rumunia, Litwa, Bułgaria i Łotwa.

\subsection{Uwagi końcowe}

Działalność innowacyjna przedsiębiorstw usługowych stanowi podporę intensywnego i zrównoważonego rozwoju gospodarczego krajów oraz regionów. Wpływa także na kształtowanie i rozwój sektora usług.

Przeprowadzona w rozdziale pogłębiona analiza danych wyraźnie wskazuje na istotną rolę sfery badawczo-rozwojowej w sektorze usług i nakładów na tę sferę, które przyczyniają się do wzrostu PKB.

Podsumowując rozważania na temat innowacyjności sektora usług nasuwają się następujące wnioski:

1. Sektor usług jest innowacyjny, ma to swój wyraz między innymi w liczbie wdrażanych technologii, wprowadzaniu na rynek nowych produktów, wielkości wydatków na działalność badawczo-rozwojową. Z drugiej strony postęp techno- 
logiczny i automatyzacja wpływają na ograniczanie wielkości wykorzystywanych zasobów pracy.

2. Innowacyjność wpływa na poziom konkurencyjności. O przewadze konkurencyjnej przedsiębiorstwa świadczy między innymi: odpowiedni kapitał, nowoczesne technologie, wykwalifikowani pracownicy.

3. Wzrost udziału przedsiębiorstw innowacyjnych z 16\% w latach 1997-1999 do 22\% w latach 2001-2003, w latach 2004-2006 udział przedsiębiorstw, które wprowadziły przynajmniej jedną innowację w sektorze usług, wyniósł $21,2 \%$.

4. Na innowacyjność przedsiębiorstw w dużym stopniu wpływa sfera badawczo-rozwojowa, dlatego też zwraca się uwagę na podejmowanie współpracy przedsiębiorstw z wspomnianymi jednostkami. W 2000 r. udział nakładów na B+R w PKB wynosił 0,64\%, w 2010 r. - 0,74\%. Dążeniem Unii jest osiagnięcie średniego poziomu wynoszącego $3 \%$ PKB, obecnie jest to $2 \%$, Polskę pod tym względem dzieli znaczny dystans od państw Unii Europejskiej.

5. W roku 2010 w porównaniu z 2009 r. nakłady na działalność innowacyjną wzrosły o ponad $30 \%$. Najwyższe nakłady na działalność innowacyjną podobnie jak w latach wcześniejszych poniosło województwo mazowieckie, najniższe podlaskie. Wynika z tego, że większe zbiorowości posiadają większe możliwości ponoszenia wyższych nakładów na działalność innowacyjną. Biorąc pod uwagę posiadanie przez nie wysokiego potencjału rozwojowego, regiony te posiadają naturalną zdolność do powiększania swojej przewagi konkurencyjnej nad słabszymi województwami. Wyniki przeprowadzonych badań wskazują na duże zróżnicowanie nakładów na działalność innowacyjną w przekroju województw.

6. Wśród wydatków na działalność innowacyjną dominowały wydatki na zakup maszyn i urządzeń technicznych, środków transportowych, narzędzi, przyrządów, ruchomości i wyposażenia, najniższe nakłady były przeznaczane na szkolenie personelu.

7. W analizowanym okresie najwyższy udział nakładów na działalność innowacyjną zaobserwowano wśród przedsiębiorstw zajmujących się działalnością telekomunikacyjną $(45,7 \%)$, finansową $(19,2)$ i handlową $(12,3 \%)$.

8 . W roku 2010 w porównaniu z 2008 r. zaobserwowano spadek udziału przychodów ze sprzedaży produktów wprowadzonych na rynek w przychodach ze sprzedaży ogółem (6,4\% w 2008, a 4,1\% w 2010 r.). W roku 2010 najwyższy udział przychodów ze sprzedaży produktów nowych lub istotnie ulepszonych w przychodach ogółem osiagnęły województwa lubelskie $(17,4 \%)$ i mazowieckie $(6,5 \%)$, najniższy podlaskie $(0,3 \%)$.

9. Uwzględniając w przychodach ze sprzedaży produktów nowych lub istotnie ulepszonych rodzaj działalności PKD, najwyższy udział przychodów był w ubezpieczeniach $(13,2 \%)$ i telekomunikacji $(11,1 \%)$.

Sumaryczny Indeks Innowacyjności wskazuje na duże zróżnicowanie państw Unii Europejskiej pod tym względem. Wartość wskaźnika dla UE-27 wynosi 0,533 , dla Polski 0,304 , co daje nam 23. pozycję w rankingu. 



\section{PROGNOZOWANIE UDZIAŁU SEKTORA USŁUG W GOSPODARCE}

\subsection{Uwagi wstępne}

Ponad dwudziestoletni okres transformacji w Polsce przyniósł wiele zmian zarówno społecznych, jak i gospodarczych. Struktura gospodarcza, która wykształciła się w gospodarce centralnie planowanej, znacznie się różniła od struktury charakterystycznej dla gospodarki rynkowej. Sektor usług ze względu na nierównowage popytową oraz niedostatek kapitału trwałego, mocy produkcyjnych, energii i surowców nie był traktowany priorytetowo (por. Jarmołowicz, Szarzec 2011, s. 87). Większą uwagę w przydziale środków koncentrowano na gałęziach produkujących dobra wyjściowe, co wynikało z ich dużego znaczenia w gospodarce, a jednocześnie doprowadziło do utwierdzenia przekonania o nieproduktywnym charakterze sektora usług. Okres gospodarki centralnie planowanej charakteryzował się wysokim odsetkiem pracujących w przemyśle oraz przeludnieniem sektora rolnego. Wythumaczeniem takiego stanu może być z jednej strony „realizacja planu industrializacji i przywiązywanie ogromnej wagi do rozwoju przemysłu, szczególnie ciężkiego, a z drugiej strony - wynikające $\mathrm{z}$ wymienionego priorytetu zacofanie rolnictwa związane $\mathrm{z}$ brakiem odpowiednich środków na inwestycje" (Jarmołowicz, Szarzec 2011, s. 87). Przywiązywanie nadrzędnej wagi do sektora przemysłowego wynikało z przekonań ideologicznych, było podyktowane także względami militarnymi oraz prawidłowościami charakterystycznymi dla gospodarki centralnie zarządzanej.

Analizując sytuację gospodarczą państwa, niejednokrotnie zadajemy sobie pytanie, dlaczego w miarę dobrze funkcjonująca gospodarka nagle zaczyna popadać w stan spowolnienia gospodarczego, pojawia się kryzys, bieda i bezrobocie. Pojawianie się cykli koniunkturalnych jest rzeczą nieuniknioną, a zdobyta przez lata wiedza i doświadczenia sprawiają, że istnieją możliwości prognozowania i przewidywania punktów zwrotnych.

Ustalenie poziomu rozwoju gospodarczego danego kraju jest bardzo trudne, ponieważ nie istnieją uniwersalne mierniki, które byłyby porównywalne w skali całego świata. Wypracowanych zostało jednak wiele metod i wymyślono dużo narzędzi wykorzystywanych do pomiaru cykliczności rozwoju gospodarczego (Garczarczyk 2009). Najczęściej stosowaną i najbardziej popularną jest metoda 
testu koniunktury, która polega na regularnym badaniu na podstawie kwestionariusza określonej grupy przedsiębiorstw. Analiza otrzymanych odpowiedzi i ich odpowiednie opracowanie pozwala dobrze przewidzieć kierunki zmian koniunktury i daje dobre informacje o krótkookresowych zmianach aktywności gospodarczej. Coraz częściej stosowane są tzw. barometry koniunktury, są to wskaźniki, których zmiana w określony sposób informuje o zmianach sytuacji gospodarczej. Otrzymywana informacja może mieć charakter bieżący, wyprzedzający lub opóźniony.

Do najbardziej skomplikowanych metod prognozowania koniunktury należą modele ekonometryczne. Najczęściej stosowaną miarą poziomu rozwoju jest produkt krajowy brutto (PKB), uzupełniany innymi miernikami ekonomicznymi oraz demograficznymi, gospodarczymi i społecznymi. W ostatnich dziesięcioleciach znaczenie sektora usług w gospodarce wzrastało w odniesieniu do udziału $\mathrm{w}$ generowaniu wartości dodanej brutto, jak również kreowania nowych miejsc pracy. Zjawisko to występowało zarówno w gospodarkach wysoko rozwiniętych, jak i tych na niższym poziomie gospodarczego rozwoju. Biorąc pod uwagę udział usług w generowaniu wartości dodanej brutto w gospodarce, można jednoznacznie stwierdzić, iż w krajach wysoko rozwiniętych udział usług jest zdecydowanie większy aniżeli sfery produkcyjnej czy rolnictwa. Rozwój gospodarczy powoduje, że coraz częściej sięgamy po metody prognozowania zarówno proste oparte na wskaźnikach ekonomicznych, jak i bardziej zaawansowane. Warto przytoczyć najważniejsze powody, dla których wyznaczane są rachunki narodowe (por. Zienkowski 2001):

- dają pełen obraz gospodarki narodowej i zmian jej struktury w czasie, zapewniają spójność pojęć i klasyfikacji stosowanych do opisu całokształtu procesów gospodarczych, są źródłem danych dla analiz sytuacji gospodarczej;

- umożliwiają prowadzenie wiarygodnych porównań międzynarodowych (stosowany obecnie w Europie system rachunków narodowych przyjmuje jako podstawę metodologiczną dwa opracowania międzynarodowe: System Rachunków Narodowych ONZ (ESA) oraz Europejski System Rachunków Narodowych i Regionalnych - ESA);

- stanowią określony standard, do którego odnoszą się wszystkie statystyki branżowe oraz funkcjonalne.

Rachunki narodowe poszerzają naszą wiedzę na temat wewnętrznej sytuacji gospodarczej kraju i przedstawiają ją na tle innych państw. Podstawowymi miernikami produkcji są produkcja globalna, wartość dodana i produkt krajowy brutto. Wartość dodana jest powszechnie uważana za dobry miernik wytworzonej produkcji, dlatego też w pracy poświęcono jej wiele uwagi. W rozważaniach nad rozwojem sektora usług słuszne wydaje się zwrócenie uwagi na tendencje rozwoju społeczno-gospodarczego w przekroju województw oraz całego kraju. 


\subsection{Prognoza PKB według sektorów gospodarki}

Prognozowanie to „racjonalne, naukowe, przewidywanie przyszłych zdarzeń" (Cieślak 1993, s. 15). Ze względu na cel i stosowane metody pojęcie prognozowania może się nieco różnić, niemniej jednak słuszne wydaje się zwrócenie uwagi na następujące właściwości prognozy (por. Cieślak 1993, s. 16):

- prognoza jest formułowana z wykorzystaniem dorobku nauki,

- jest stwierdzeniem odnoszącym się do określonej przyszłości,

- stwierdzeniem weryfikowalnym empirycznie,

- nie jest stwierdzeniem stanowczym, ale jest stwierdzeniem akceptowanym.

Czerwiński (1982, s. 19) uważa, że: „Przez prognozę rozumiemy sąd o zajściu określonego zdarzenia $\mathrm{w}$ czasie określonym $\mathrm{z}$ dokładnością do momentu (punktu) lub okresu (przedziału) czasu należącego do przyszłości”. Według Hellwiga (1970, s. 148), „Prognozą statystyczną nazywać będziemy każdy sąd, którego prawdziwość jest zdarzeniem losowym, przy czym prawdopodobieństwo tego zdarzenia jest znane i wystarczająco duże dla celów praktycznych".

Gospodarka danego kraju pod wpływem wielu czynników zmienia się w czasie. Obserwowane zmiany wartości odpowiednich wskaźników makroekonomicznych pozwalają przewidywać rozwój koniunktury gospodarczej oraz aktywnie wpływać na te zmiany. Przyjmuje się, że podstawowym miernikiem w gospodarce jest Produkt Krajowy Brutto (PKB), który obrazuje końcowy rezultat działalności wszystkich podmiotów gospodarczych. Tempo wzrostu produktu krajowego brutto jest bacznie obserwowane przez ekonomistów i inwestorów (rys. 5.1).

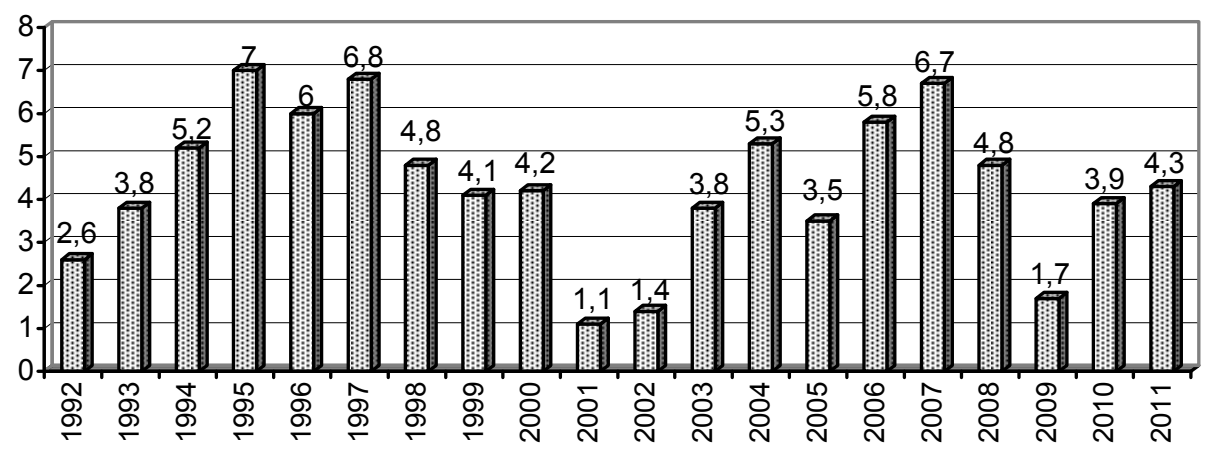

Rys. 5.1. Tempo wzrostu PKB w Polsce w latach 1992-2011

Źródło: opracowanie własne na podstawie danych GUS, www.stat.gov.pl. [29.12.2012]. 
Podstawowym wskaźnikiem od strony tworzenia PKB jest wartość dodana brutto (WDB). Analiza wartości dodanej brutto w poszczególnych sektorach oraz państwach Unii Europejskiej pozwala na zaobserwowanie pewnych prawidłowości. Na rys. 5.2 przedstawiono strukturę wartości dodanej brutto w Polsce $\mathrm{w}$ podziale na trzy sektory. Sektor usług $\mathrm{w}$ analizowanym okresie charakteryzował się największym udziałem w tworzeniu wartości dodanej brutto, znacznie spadł udział sektora rolnego, obserwujemy także systematyczny spadek udziału sektora przemysłowego. Struktura wartości dodanej brutto w trójsektorowym podziale gospodarki w Polsce zbliża się do struktury krajów o rozwiniętej gospodarce rynkowej. W 1994 r. na sektor rolny przypadało 8\% wartości dodanej brutto, na sektor przemysłowy 35\%, zaś na usługi $57 \% \mathrm{~W}$ roku 2010 proporcje te uległy znacznym zmianom, na sektor rolny przypadało $4 \%$, przemysłowy $32 \%$ i usługowy $65 \%$. Wzrost wartości dodanej brutto w sektorze usług następuje we względnie stabilnym tempie.

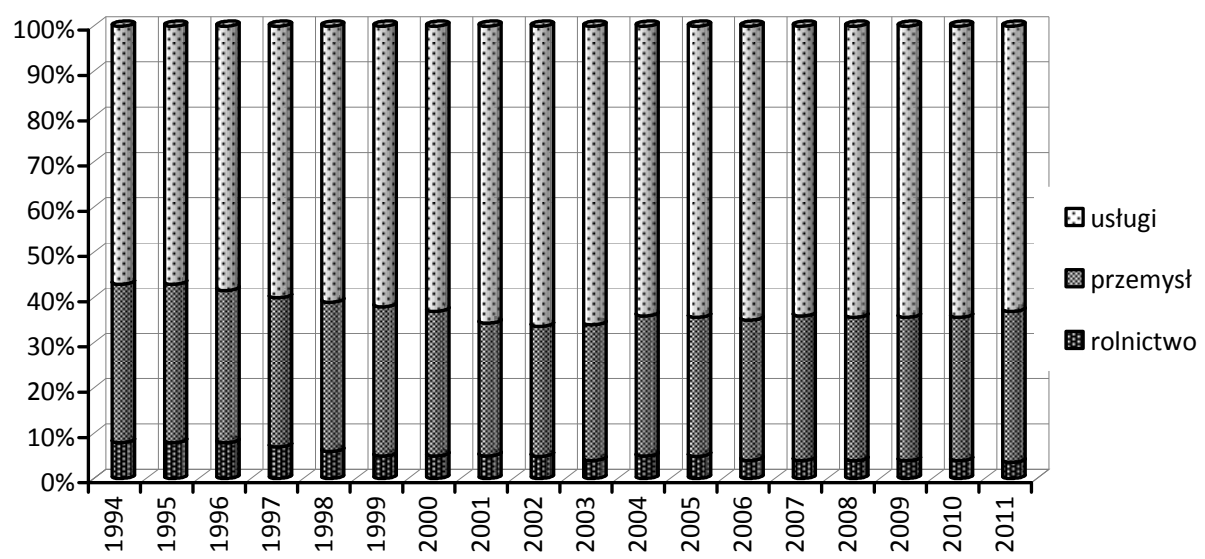

Rys. 5.2. Udziały trzech sektorów w całkowitej wartości dodanej brutto w latach 1994-2011 w Polsce

Źródło: opracowanie własne na podstawie danych OECD.

Porównując sektor usług w Polsce z sektorami państw Unii Europejskiej, uwagę zwraca gospodarka Niemiec uchodząca w ostatnim okresie za gospodarkę dość stabilną. W ostatnich latach w Niemczech struktura wartości dodanej brutto także uległa zmianie (rys. 5.3): w roku 1995 sektor rolny wytwarzał 1,3\% wartości dodanej brutto, przemysł $32,1 \%$, usługi $66,6 \%$, w roku $2010 \mathrm{w}$ rolnictwie zaobserwowano $0,9 \%$, w przemyśle $28,2 \%$ natomiast sektor usług wytworzył $70,9 \%$ wartości dodanej brutto. Ten obserwowalny spadek produkcji przemy- 
słowej oraz wzrost sektora usług $\mathrm{w}$ gospodarce niemieckiej jest zgodny $\mathrm{z}$ tendencją występującą $\mathrm{w}$ gospodarkach państw wysoko rozwiniętych. Porównując gospodarkę Niemiec z gospodarkami USA czy Szwecji, nasuwają się trzy spostrzeżenia (Szukalski 2001). Mianowicie, w gospodarce RFN w porównaniu z gospodarkami państw wymienionych występował znaczny udział sektora przemysłowego, który thumaczy się proeksportowym charakterem tej gospodarki. Poza tym zwraca się uwagę na różne tempo absorpcji siły roboczej przez usługi w poszczególnych krajach i zróżnicowanie w samej strukturze usług. Niemniej jednak Internationales Institut für Politik und Wirtschaft (Międzynarodowy Instytut Polityki i Gospodarki) (http://www.hausrissen.org/), podkreśla, że społeczeństwu niemieckiemu trudno było się przestawić ze społeczeństwa przemysłowego na społeczeństwo pracujące w usługach, być może podejście takie częściowo było spowodowane obawą o działalność sektora przemysłowego.

Dane dotyczące sektora rolnego zwracają uwagę na znaczny jego spadek w wytwarzaniu wartości dodanej brutto; zastanawiająca jest sytuacja w sektorze przemysłowym, pomimo, że nastapił spadek udziału tego sektora w wartości dodanej brutto, to nadal jest on utrzymywany na dość wysokim poziomie. Konkurencyjność i sukces niemieckiego przemysłu tkwi w innowacyjności, która jest wynikiem intensywnej współpracy z ośrodkami naukowymi. Niemiecki przemysł koncentruje się głównie na innowacjach produktowych i procesowych, które są trudne do skopiowania i zastąpienia tanią siłą roboczą. Umiejętna dbałość o sektor przemysłowy sprawiła, że gospodarka Niemiec przeżywa okres gwałtownego ożywienia.

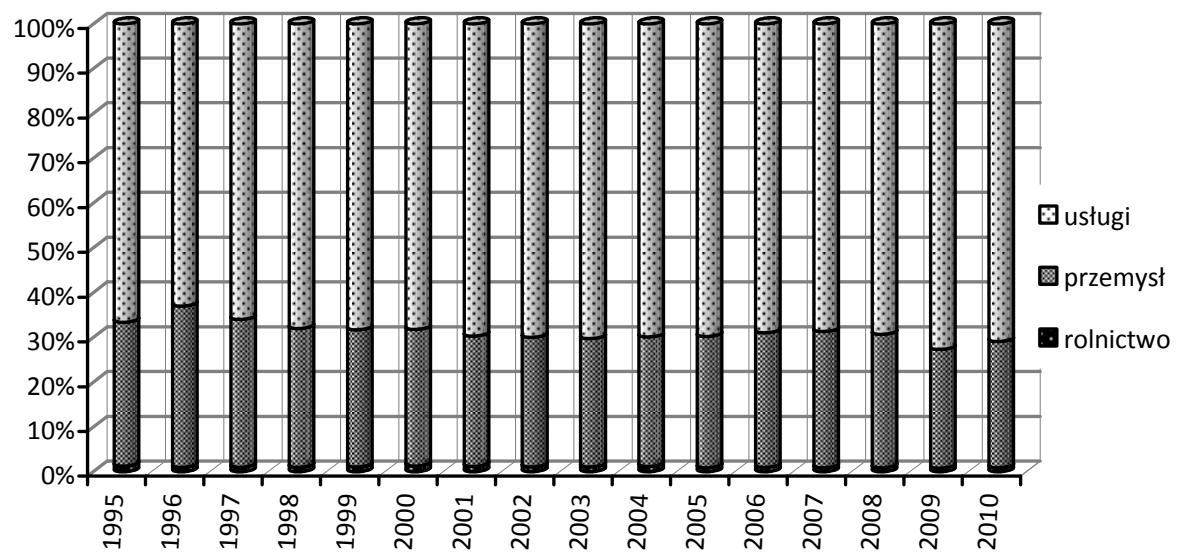

Rys. 5.3. Udziały trzech sektorów w całkowitej wartości dodanej brutto w latach 1995-2010 w Niemczech

Źródło: opracowanie własne na podstawie danych GUS, www.stat.gov.pl. [13.11.2012]. 
Analizy wartości dodanej brutto dokonano także w pozostałych państwach Unii Europejskiej, uwzględniając sektor usług (por. rys. 5.5).

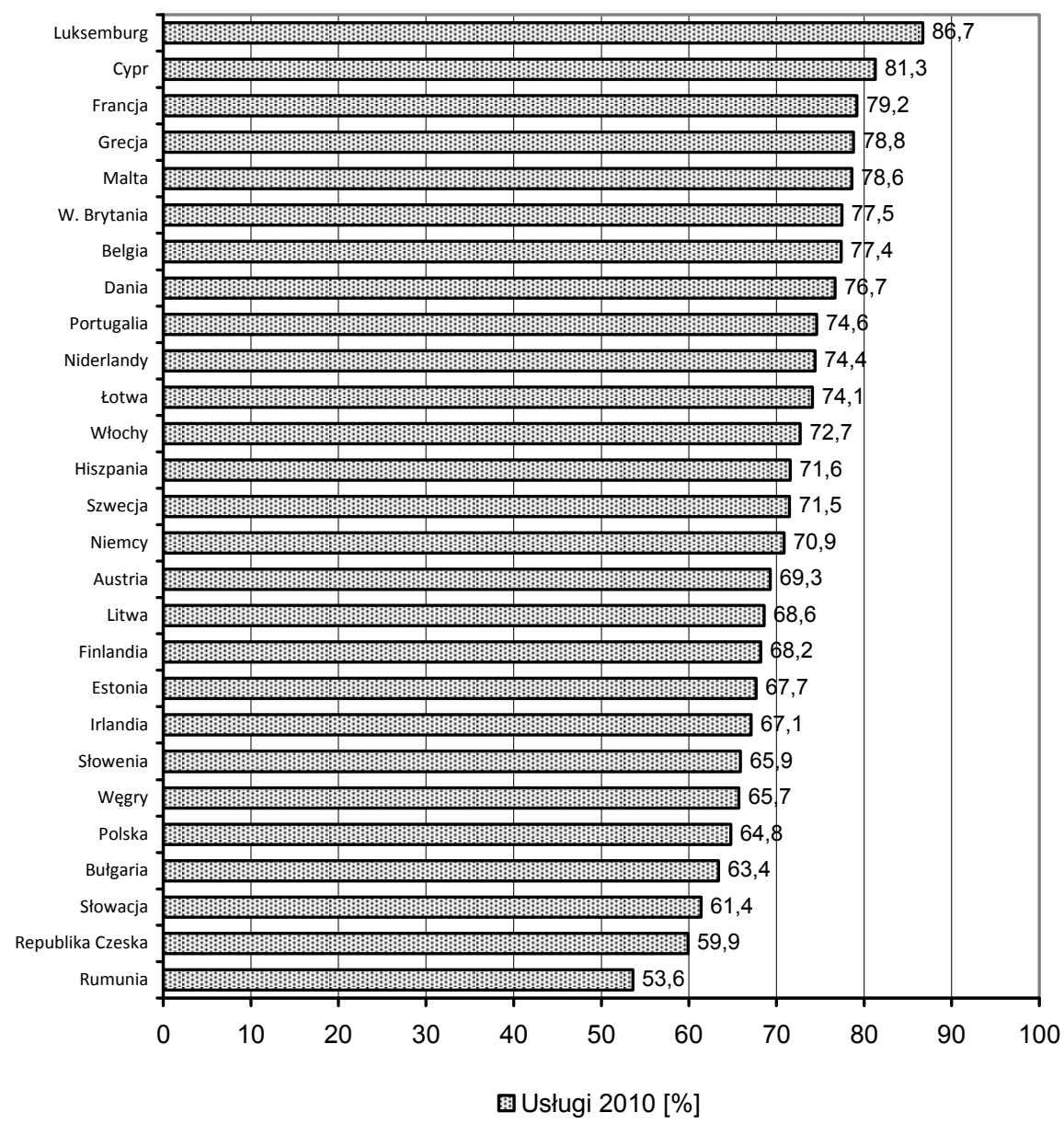

Rys. 5.4. Udział sektora usług w całkowitej wartości dodanej brutto w państwach Unii Europejskiej w 2010 r.

Źródło: opracowanie własne na podstawie Rocznik Statystyczny Rzeczypospolitej Polskiej 2011.

We wszystkich analizowanych państwach Unii Europejskiej zaobserwowano wzrost znaczenia sektora usług w zakresie wartości dodanej brutto. Najmniejszy przyrost o 0,1 punktu procentowego w okresie 2000-2010 nastapił w Estonii i Rumunii, najwyższy w Luksemburgu $(86,7)$, Cyprze $(81,3)$ i Francji $(79,2)$. W przypadku Polski nastąpił niewielki przyrost o 1,4 punktu procentowego. 
Znaczne różnice $\mathrm{w}$ poziomie wartości dodanej brutto pomiędzy Polską a państwami najwyżej rozwiniętymi pozwalają sądzić, że w miarę rozwoju społecznogospodarczego nastapi wzrost znaczenia sektora usług w polskiej gospodarce. Analiza danych pozwala stwierdzić, że większość gospodarek państw wysoko rozwiniętych oparta jest na sektorze usług, zaś gospodarki państw rozwijających się naśladują to postępowanie, dążąc do zwiększania sektora usług w tworzeniu PKB. Zwiększanie udziału sektora usług następuje kosztem zmniejszania sektora rolnego i sektora przemysłowego. Największe zmiany w udziale sektora usług w całkowitej wartości dodanej brutto w ostatnich latach zaobserwowano w Irlandii i Finlandii (rys. 5.5).

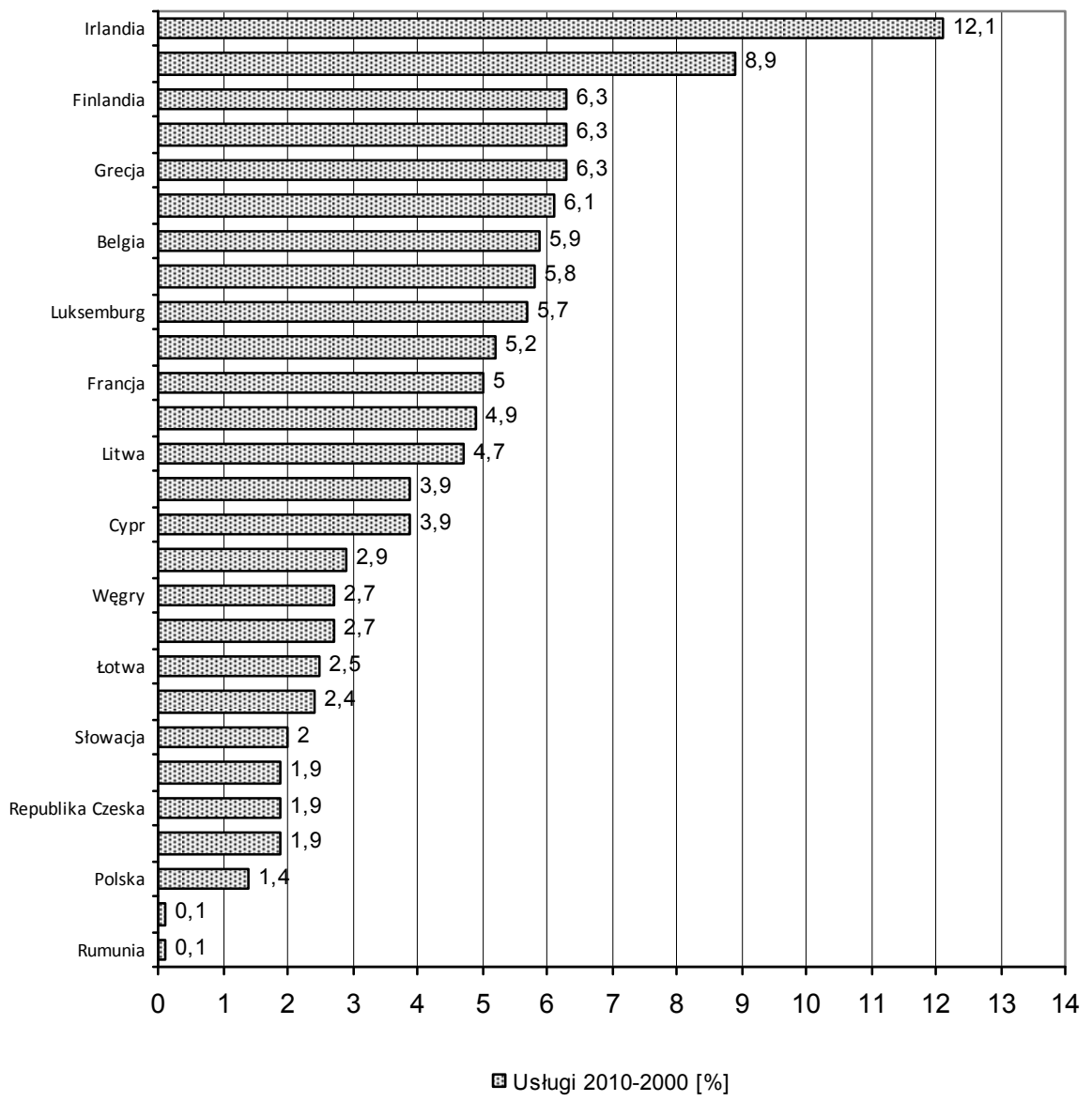

Rys. 5.5. Zmiana udziału sektora usług w całkowitej wartości dodanej brutto w państwach Unii Europejskiej - porównanie roku 2010 i 2000

Źródło: obliczenia własne na podstawie Rocznik Statystyczny Rzeczypospolitej Polskiej 2011. 
W celu określenia stanu gospodarki wykorzystuje się różne wskaźniki ekonomiczne. Do najważniejszych wskaźników makroekonomicznych zalicza się Produkt Krajowy Brutto (PKB), stopę bezrobocia oraz stopę inflacji. „Produkt krajowy brutto (PKB) jest najbardziej kompleksowym miernikiem całkowitej produkcji dóbr i usług danego kraju. Jest sumą pieniężnych wartości konsumpcji, inwestycji brutto, państwowych zakupów towarów i usług oraz eksportu netto wytworzonego w kraju w ciagu roku" (Samuelson 2004, s. 34). PKB jest syntetycznym wskaźnikiem opisującym gospodarkę, jego wzrost świadczy o bogaceniu się społeczeństwa natomiast spadek o ubożeniu. Na rys. 5.1. przedstawiono tempo wzrostu PKB w Polsce w latach 1992-2011.

Sektor usług dynamicznie się rozwija we wszystkich analizowanych krajach. $\mathrm{W}$ związku z tym potrzebne jest prognozowanie tego sektora. W wyniku wielu analiz danych potwierdzających rozwój sektora usług w Polsce i państwach Unii Europejskiej podjęto próbę wyznaczenia prognozy udziału wartości dodanej brutto w sektorze usług w Polsce. W tym celu skorzystano $\mathrm{z}$ bazy danych GUS, zawierającej informacje na temat wartości dodanej brutto w latach 2000-2012 (dane kwartalne). W badaniu rozwoju sektora usług oparto się na założeniu, że rozwój sektora usług wynika ze wzrostu wartości dodanej brutto.

Prognozę wartości dodanej brutto przeprowadzono przy wykorzystaniu liniowej funkcji trendu. Założono, że postać analityczna modelu oraz wartości ocen jego parametrów nie ulegną zmianie w przedziale czasu, dla którego wyznacza się prognozę.

Oszacowana funkcja trendu ma postać:

$$
\hat{y}_{t}=2504,7 t+91127,47 \quad \mathrm{~S}=7353,9 \quad R^{2}=0,961 .
$$

Z funkcji trendu wynika, że w badanym okresie wartość dodana brutto wzrastała kwartalnie średnio o 2504,7 mln zł, w kwartale poprzedzającym pierwszy badany wyniosła 91 127,47 mln zł. Zmienność wartości dodanej brutto w badanym okresie została wyjaśniona przez oszacowaną funkcję trendu w 96\% $\left(R^{2}=0,961\right)$.

Znajomość parametrów funkcji trendu, przy założeniu, że tendencja rozwojowa nie ulegnie zmianie, pozwala zaobserwować dalszy wzrost wartości dodanej wytwarzanej przez sektor usług.

W pracy podjęto także próbę prognozowania wartości dodanej brutto z uwzględnieniem zjawiska sezonowości, wykorzystując metodę Wintersa (por. rozdz. 2.9). Wyboru metody dokonano na podstawie analizy szeregu czasowego zmiennej prognozowanej, po zaobserwowaniu, że zawiera tendencję rozwojową, wahania sezonowe i wahania przypadkowe. Prognozę wyznaczono w sposób sekwencyjny, korzystając z trzech równań zawierających trzy parametry wygładzania. Na rys. 5.7 przedstawiono prognozy wartości dodanej brutto w sektorze usług dla kolejnych kwartałów. 


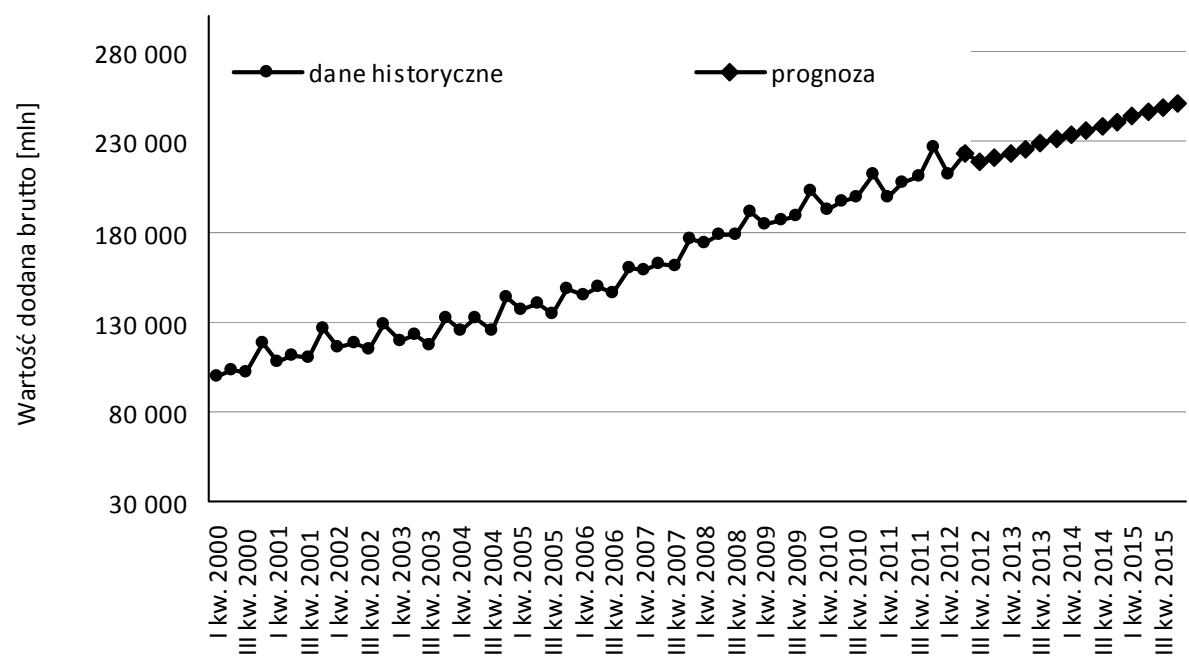

Rys. 5.6. Rzeczywiste i prognozowane poziomy wartości dodanej brutto w sektorze usług Źródło: obliczenia własne na podstawie danych GUS, www.stat.gov.pl. [10.02. 2013].

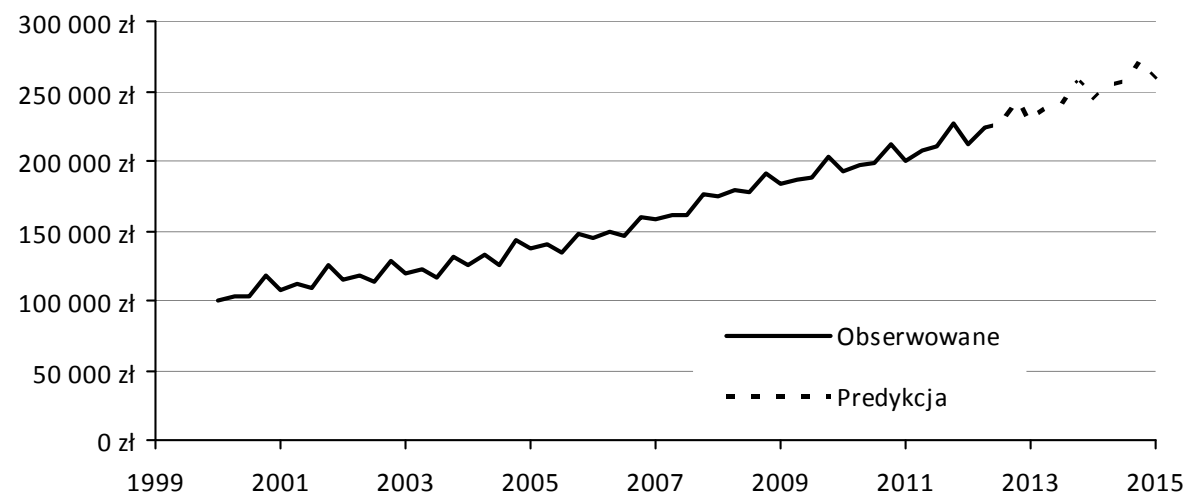

Rys. 5.7. Rzeczywiste i prognozowane poziomy wartości dodanej brutto w sektorze usług Źródło: obliczenia własne na podstawie danych GUS, www.stat.gov.pl [10.02. 2013].

Przyjęto założenie, że wartości parametrów są równe $\alpha=0,449867$, $\beta=0,458045, \gamma=1$. Prognozowane wartości dla kolejnych kwartałów $2012 \mathrm{r}$. wynoszą dla trzeciego kwartału $224002 \mathrm{mln}$, dla czwartego $225900 \mathrm{mln}$, natomiast dla pierwszego i drugiego kwartału 2013 odpowiednio: 241201 i 227808 mln zł. 
Prognozy przygotowane przez Instytut Badań nad Gospodarką Rynkową (Stan i prognoza..., nr 76/2012) wskazuja, że tempo wzrostu produktu krajowego brutto w 2012 r. wyniesie 2,4\%, co świadczy o znacznym spowolnieniu w stosunku do 2011 r. Dla 2013 r. prognozuje się tempo wzrostu na poziomie 2\%, czyli poniżej tempa z 2012 r. Instytut na pierwsze dwa kwartały 2013 r. szacuje dalsze spowolnienie wzrostu gospodarczego, w pierwszym kwartale 2013 r. PKB rósł będzie o 1,6\%, a w drugim o 1,4\%. Zmiana tej tendencji planowana jest na trzeci kwartał 2013 r., prognozuje się, że w trzecim kwartale PKB będzie rósł w tempie 2,1\%, a w czwartym w tempie 2,5\%. Spowolnienie rozwoju gospodarczego zaobserwujemy we wszystkich sektorach gospodarki. W czwartym kwartale 2012 r. wartość dodana w przemyśle wzrośnie jedynie o $0,3 \%$, w budownictwie spadnie o $1 \%$, największym optymizmem napawa sektor usług rynkowych ze wzrostem w czwartym kwartale 2012 roku o 3,4\%. Informacje na temat prognoz produktu krajowego brutto i wartości dodanej przedstawiono w tab. 5.1.

Tablica 5.1. Roczne i kwartalne prognozy produktu krajowego brutto i wartości dodanej

\begin{tabular}{|l|r|r|r|c|c|c|c|c|}
\hline \multirow{2}{*}{ Wyszczególnienie } & \multicolumn{2}{|c|}{2012} & \multicolumn{4}{c|}{2013} & \multirow{2}{*}{2012} & \multirow{2}{*}{2013} \\
\cline { 2 - 9 } & III & IV & I & II & III & IV & & \\
\hline PKB (\%r/r) & 1,9 & 1,8 & 1,6 & 1,4 & 2,1 & 2,5 & 2,4 & 2,0 \\
\hline PKB (\%k/k) & 0,5 & 0,5 & 0,4 & 0,4 & 0,5 & 0,6 & $\times$ & $\times$ \\
\hline Wartość dodana w przemyśle & 0,7 & 0,3 & 0,3 & 0,1 & 1,2 & 2 & 1,7 & 1,0 \\
\hline Wartość dodana w budownictwie & $-4,1$ & $-1,0$ & 0,5 & 0,1 & 1,4 & 2,5 & 0,5 & 1,3 \\
\hline Wartość dodana w usługach rynkowych & 3,5 & 3,4 & 2,7 & 2,4 & 2,9 & 3,1 & 3,5 & 2,8 \\
\hline
\end{tabular}

Źródło: obliczenia własne na podstawie danych GUS, www.stat.gov.pl. [05.05 2013].

Ze względu na opóźnienia w raportowaniu oraz częste rewizje korzystanie z PKB, co nie zawsze jest wygodne, dlatego często sięga się po inne miary. Są to barometry koniunktury, służące do badania cykliczności gospodarki oraz prognozowania krótkookresowego oraz wielokomponentowe wskaźniki równoległe, wyprzedzające i opóźnione (Drozdowicz-Bieć 2012). Wskaźnik Równoległy Koniunktury (WRK) określa aktualny stan gospodarki i wykazuje silny związek z PKB. Do najczęściej stosowanych składowych WRK należą: produkcja sprzedana przemysłu, sprzedaż detaliczna towarów i usług, sprzedaż hurtowa, dochody osobiste, wynagrodzenia i płace, zatrudnienie oraz bezrobocie. Wskaźnik WRK jest publikowany co miesiąc, dlatego też jest wykorzystywany do aktualnej oceny rozwoju gospodarki oraz szacowania PKB. Wskaźnik Wyprzedzający Koniunktury (WWK) jest krótkookresową prognozą ogólnej aktywności gospodarczej (Szacunek PKB... 2011). Składowymi WWK mogą być: podaż pienią- 
dza M3, WIG, zadłużenie gospodarstw domowych z tytułu kredytów, wydajność pracy $\mathrm{w}$ przemyśle, napływ nowych zamówień do przedsiębiorstw sektora przemysłowego, zapasy wyrobów gotowych w przemyśle, ocena stanu finansów firm przemysłowych oraz oceny menedżerów przedsiębiorstw na temat kondycji gospodarki.

Drozdowicz-Bieć (2012) za dobre komponenty wskaźnika wyprzedzającego uznaje znacznie szerszy zbiór komponentów: wielkość zamówień, zapasów, podaż pieniądza, czas dostaw, wyniki finansowe przedsiębiorstw, oczekiwania menedżerów/konsumentów co do przyszłej sytuacji gospodarczej, wartości indeksów giełdowych, ceny niektórych surowców, liczby wydanych zezwoleń budowlanych, wykorzystanie mocy produkcyjnych, wydajność pracy, liczbę nowo powstałych firm oraz liczbę bankructw. Średni okres wyprzedzenia wskaźnika WWK w stosunku do rzeczywistych stanów zachodzących w gospodarce wynosi od 3 do 12 miesięcy. Na rys. 5.8 przedstawiono Wskaźnik Równoległy Koniunktury i Wskaźnik Wyprzedzający Koniunktury w latach 19902012. Różny dobór komponentów, będących składowymi wskaźników równoległych i wyprzedzających, może spowodować nieco odmienny ich przebieg. Wyróżnia się trzy cechy różniące przebieg wskaźników wyprzedzających i równoległych, są to (Drozdowicz-Bieć 2012, s. 93):

- większy udział trendu w konstrukcjach wskaźników wyprzedzających w stosunku do udziału trendu w konstrukcjach wskaźników równoległych,

- wyższa amplituda wahań wskaźnika wyprzedzającego w porównaniu ze wskaźnikiem równoległym,

- zróżnicowanie wyprzedzeń punktów zwrotnych wskaźników wyprzedzających w stosunku do wskaźnika równoległego w górnych i dolnych punktach zwrotnych cyklu koniunktury.

Analiza wskaźnika równoległego koniunktury w latach 1990-2012 (rys. 5.8) pozwala na wyodrębnienie dwóch cykli koniunkturalnych oraz określenie dwóch górnych punktów zwrotnych (1998/01 i 2008/01) i trzech dolnych (1991/11, 2002/02, 2009/02) (Drozdowicz-Bieć 2012).

Wskaźnik Wyprzedzający od końca 2010 r nie wykazuje tendencji wzrostowej. Według Biura Inwestycji i Cykli Ekonomicznych (BIEC) (Szacunek PKB... 2011) gospodarka polska powróciła do trendu rozwojowego sprzed światowego kryzysu z lat 2007-2009. Przebieg WWK z 2011 r. i pierwszych miesięcy 2012 r. nie wskazuje na możliwość zwiększenia dynamiki wzrostu gospodarczego, należy raczej spodziewać się utrzymania dotychczasowej skali wzrostu na poziomie roku 2010. Prognozę taką dodatkowo potwierdza wysoki poziom inflacji, redukujący spożycie indywidualne, narastające zapasy wyrobów gotowych w magazynach firm, a także pogarszająca się sytuacja finansowa przedsiębiorstw. 


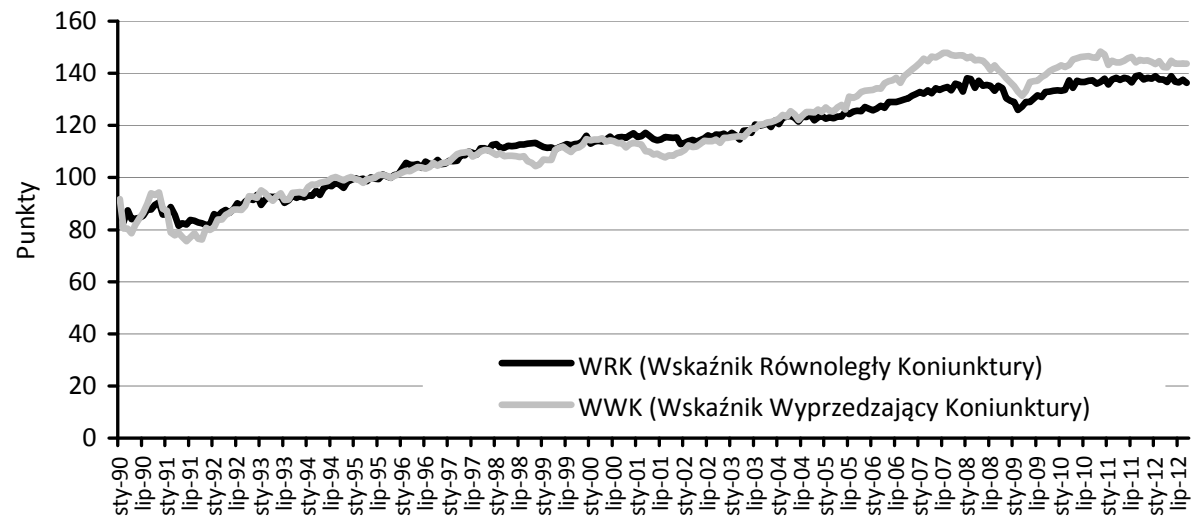

Rys. 5.8. Wskaźnik Równoległy Koniunktury i Wskaźnik Wyprzedzający Koniunktury

Źródło: opracowanie własne na podstawie danych udostępnionych przez Biuro Inwestycji i Cykli Koniunkturalnych, www.biec.org [10.09. 2012].

Pierwsze sygnały spowolnienia gospodarczego z lat 2007-2009 wskaźnik WWK zarejestrował na przełomie roku 2006 i 2007. Oczywiście, w pierwszej połowie 2007 r. wskaźnik WWK rósł osiagając najwyższą wartość w lipcu 2007 r., lecz jego tzw. miary pomocnicze, do których zaliczamy wskaźnik dyfuzji, wykazywały silną tendencje spadkową od początku 2007 r. Pierwsze oznaki wychodzenia ze stanu spowolnienia gospodarczego i odwrócenia negatywnego trendu WWK pojawiły się w marcu 2009 r. (rys. 5.8). Wychodzenie gospodarki $\mathrm{z}$ takiego stanu potwierdziły między innymi: poprawa sytuacji finansowej przedsiębiorstw, wzrost notowań spółek na giełdzie, napływ nowych zamówień $\mathrm{w}$ przedsiębiorstwach oraz wzrost wydajności pracy. W listopadzie $2010 \mathrm{r}$. WWK osiagnął poziom sprzed światowej recesji z $2007 \mathrm{r}$. W celu zbadania zależności pomiędzy wskaźnikami WRK i WWK policzony został współczynnik korelacji Pearsona. Współczynnik korelacji dla wskaźników wyniósł 0,98, co świadczy o występowaniu silnej korelacji pomiędzy wskaźnikami.

Przy konstruowaniu prognoz należy mieć jednak świadomość, że żadna prognoza z pełną dokładnością nie przewidzi przyszłości. Niejednokrotnie wystarczy, aby określić ogólny kierunek rozwoju badanych wielkości ekonomicznych.

\subsection{Koniunktura w sektorze usług}

Przedmiotem rozważań w tej części pracy są zależności pomiędzy koniunkturą gospodarczą a rozwojem sektora usług. Podjęto próbę zbadania wrażliwości koniunkturalnej sektora usług oraz poszczególnych jego działów. 
Podstawowym źródłem informacji na temat kondycji gospodarki są badania statystyczne, które dostarczają najważniejszych danych zarówno o charakterze ilościowym, jak i jakościowym. W Polsce w 1992 r. GUS wprowadził badanie koniunktury w przemyśle, w 1993 r. rozpoczęto badanie koniunktury w budownictwie, następnie w handlu. Ze względu na zwiększającą się rolę usług w gospodarce w 2003 r. podjęto badanie koniunktury w usługach. Badaniem koniunktury w usługach objęte są podmioty zaklasyfikowane według PKD 2007 do następujących sekcji (Badanie koniunktury... 2010):

- transport i gospodarka magazynowa (sekcja $\mathrm{H}$ ),

- działalność związana z zakwaterowaniem i usługami gastronomicznymi (sekcja I),

- informacja i komunikacja (sekcja J),

- działalność finansowa i ubezpieczeniowa (sekcja K),

- działalność związana z obsługą rynku nieruchomości (sekcja L),

- działalność profesjonalna, naukowa i techniczna (sekcja M),

- działalność w zakresie usług administrowania i działalność wspierająca (sekcja N),

- edukacja (sekcja P),

- opieka zdrowotna i pomoc społeczna (sekcja Q),

- działalność związana z kulturą, rozrywką i rekreacją (sekcja R),

- pozostała działalność usługowa (sekcja S).

Badanie koniunktury w sektorze usług odbywa się za pomocą metody testu koniunktury na próbie liczącej 5008 jednostek usługowych, które należą do sekcji od H do S (z wyłączeniem sekcji O) (Koniunktura... 2012, s. 1). Celem testów jest stwierdzenie, że w cyklu koniunktury istotną rolę odgrywają psychologiczne czynniki zachowania się podmiotów gospodarczych. Test koniunktury (aneks 8) daje możliwość obserwacji podmiotów gospodarczych w momencie podejmowania decyzji (por. Kowalewski 2011). Pytania zawarte w ankiecie dotyczą głównych cech koniunktury jednostek usługowych: sytuacji gospodarczej podmiotu usługowego, popytu na usługi, poziomu zatrudnienia, napotykanych barier, sprzedaży usług, mocy produkcyjnych, zagwarantowanego okres działania podmiotu, sytuacji finansowej, ceny oferowanych usług, źródeł finansowania działalności oraz wielkości nakładów inwestycyjnych (12 pytań diagnostycznych i 9 pytań prognostycznych). Na podstawie uzyskanych informacji obliczane się odpowiednie wskaźniki, które są ważone przychodami ze sprzedaży produktów, towarów i materiałów w cenach bieżących i przyjmują wartości liczbowe z przedziału od -100 do +100 . Jeśli otrzymana wartość jest dodatnia, oznacza dobrą koniunkturę, wartość ujemna informuje o złej koniunkturze. Wzrost wartości otrzymanego wskaźnika świadczy o poprawie koniunktury, spadek o jej pogarszaniu się z punktu widzenia badanych jednostek. Wskaźnik ogólny informujący o koniunkturze gospodarczej jednostek jest wskaźnikiem 
liczonym jako średnia arytmetyczna sald odpowiedzi na pytania dotyczące bieżącej i przewidywanej sytuacji badanych jednostek. Uważa się, że koniunktura jest ,dobra”, gdy wskaźnik jest większy od zera, w odwrotnej sytuacji, gdy wskaźnik jest mniejszy od zera, koniunktura jest uważana za „złą” (Koniunktura... 2012).

Przeprowadzane przez GUS badania koniunktury dostarczają informacji o kierunkach zmian zachodzących w gospodarce, służą do analiz trendów rozwoju gospodarczego. Umiejętne przewidywanie przez badane jednostki przyszłości ma istotne znaczenie dla analiz sytuacji gospodarczej, ponieważ uzyskiwane w badaniach koniunktury opinie mogą być źródłem nadchodzących z rynku sygnałów o ożywieniu lub załamaniu gospodarki. Analizując wyniki badań koniunktury w danym miesiącu, należy zwracać uwagę nie tylko na to, czy omawiany wskaźnik jest dodatni, czy ujemny, ale także na kierunek zachodzących zmian.

Według Instytutu Badań nad Gospodarką Rynkową najszybciej rozwijającym się w drugim kwartale 2012 r. sektorem gospodarki były usługi. Tempo wzrostu wartości dodanej w usługach rynkowych wyniosło $3,1 \%$, tempo wzrostu wartości dodanej w przemyśle w tym samym okresie wyniosło 2,3\% (por. Kwartalne prognozy makroekonomiczne, $\mathrm{nr} 75$ ).

We wrześniu 2012 r. w sektorze usług, w ponad połowie badanych sekcji oceniana przez przedsiębiorstwa usługowe koniunktura była niekorzystna. $\mathrm{Na}$ rys, 5.9-5.19 przedstawiono koniunkturę przedsiębiorstw usługowych $\mathrm{w}$ poszczególnych sekcjach.

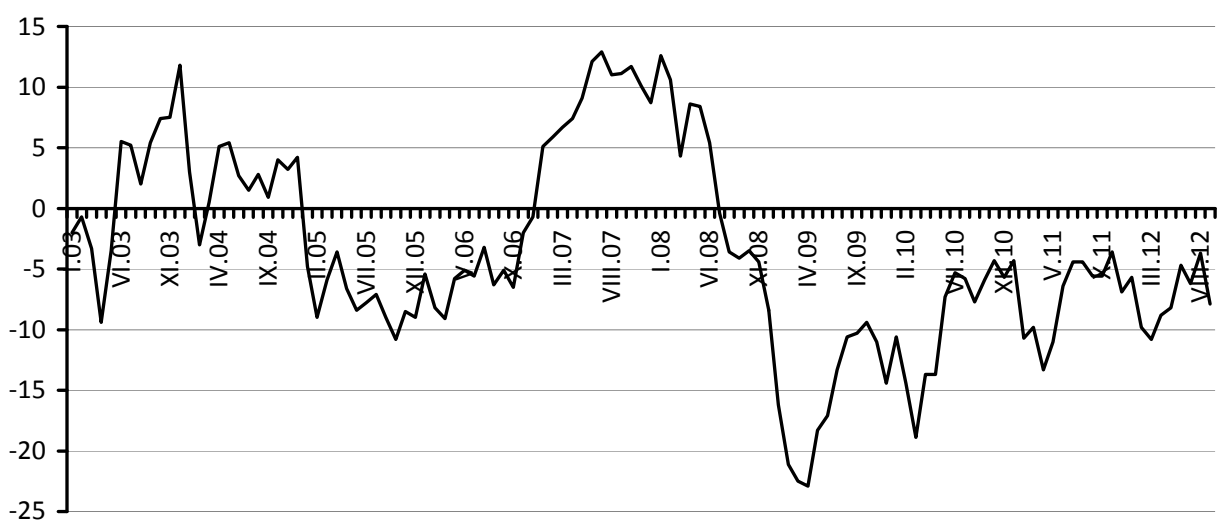

Rys. 5.9. Koniunktura w sekcji Transport i Gospodarka Magazynowa Źródło: opracowanie własne na podstawie danych GUS, www.stat.gov.pl [10.03.2013]. 
We wrześniu 2012 r. wskaźnik ogólnego klimatu koniunktury w sekcji transport i gospodarka magazynowa kształtował się na poziomie minus 7, w sierpniu wyniósł minus 5. Od sierpnia 2008 r. wartość wskaźnika utrzymuje się na ujemnym poziomie. Prognozy przewidują redukcję zatrudnienia w tej sekcji usług. Według GUS (Badanie koniunktury, 2012-10-23), w październiku 2012 r. wskaźnik ogólnego klimatu koniunktury w sekcji transport i gospodarka magazynowa uległ dalszemu pogorszeniu, osiagając poziom minus 9. Początek 2013 r. nie przyniósł poprawy, w lutym wskaźnik ogólnego klimatu koniunktury kształtował się na poziomie minus 9 .

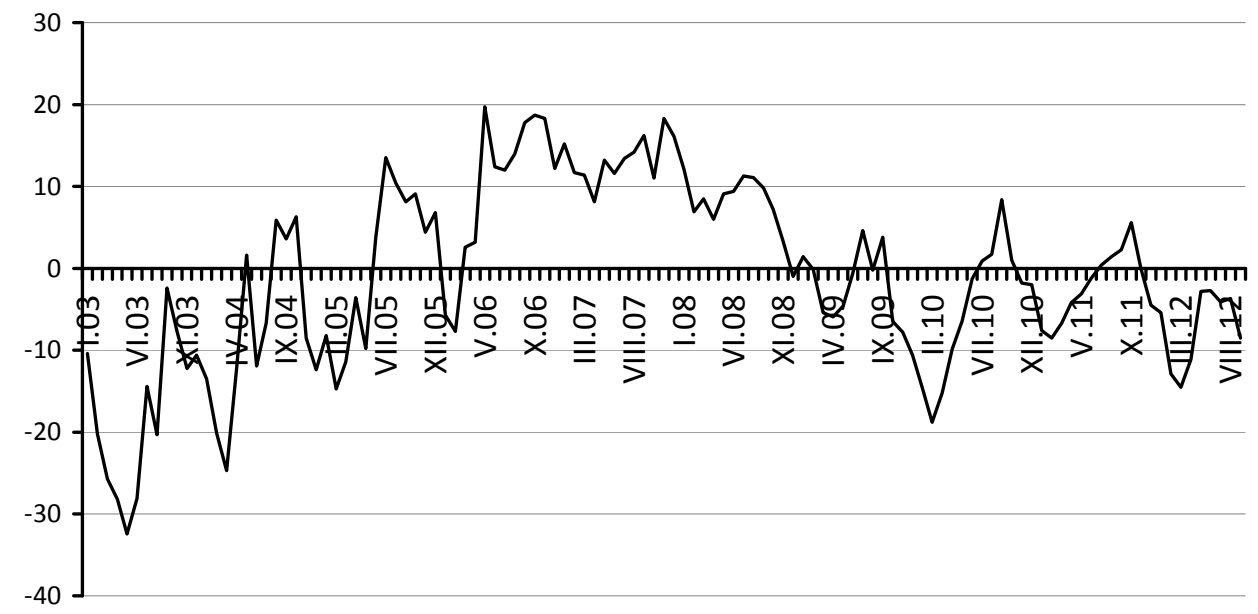

Rys. 5.10. Koniunktura w sekcji Działalność Związana z Zakwaterowaniem i Usługami Gastronomicznymi

Źródło: opracowanie własne na podstawie danych GUS, www.stat.gov.pl [10.03.2013].

Podobnie jak w sekcji transport i gospodarka magazynowa w sekcji zakwaterowanie i gastronomia wskaźnik ogólnego klimatu koniunktury kształtował się na ujemnym poziomie (minus 13). Ujemna wartość wskaźnika utrzymuje się od grudnia $2011 \mathrm{r}$. Uważa się, że negatywne oceny koniunktury wynikają z niekorzystnych ocen popytu, sprzedaży i sytuacji finansowej. W październiku $2012 \mathrm{r}$. wskaźnik ogólnego klimatu koniunktury nadal uległ pogorszeniu, kształtując się na poziomie minus 15, w lutym 2013 wynosił minus 7.

Znacznie lepsza sytuacja $\mathrm{w}$ porównaniu $\mathrm{z}$ dwoma poprzednimi sekcjami miała miejsce w sekcji informacja i komunikacja, wskaźnik ogólnego klimatu koniunktury we wrześniu 2012 r. wynosił plus 7. Od początku okresu badawczego sekcja ta wykazuje dobrą koniunkturę. Dodatnią ocenę koniunktury tłumaczy się pozytywnymi prognozami popytu i sprzedaży. Niemniej jednak w październiku w porównaniu z wrześniem 2012 r. zanotowano niewielki spadek wskaźnika do poziomu plus 5. W lutym 2013 wartość wskaźnika wynosiła plus 7. 


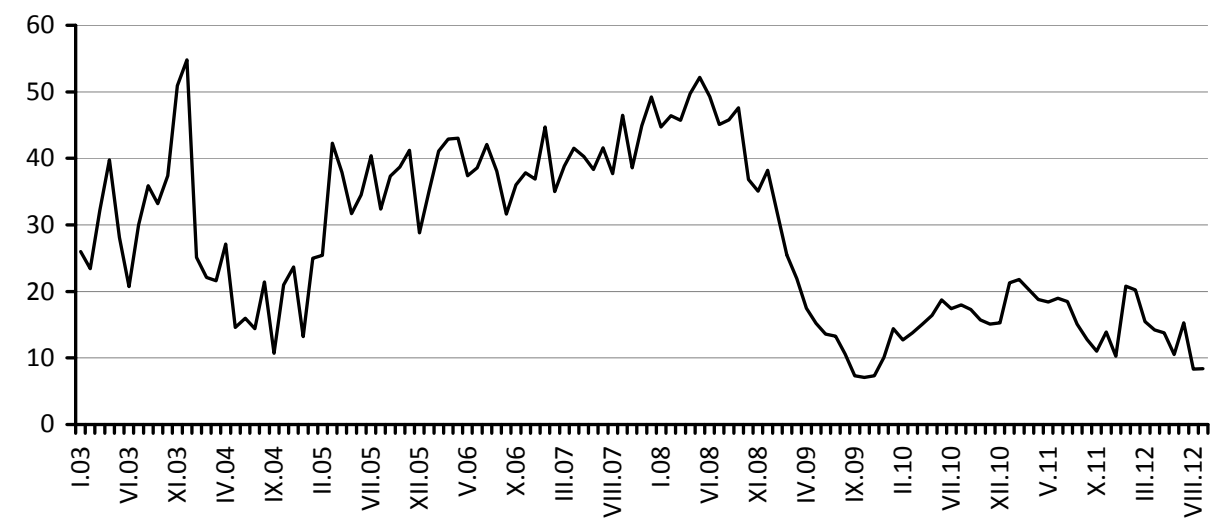

Rys. 5.11. Koniunktura w sekcji Informacja i Komunikacja

Źródło: opracowanie własne na podstawie danych GUS, www.stat.gov.pl [10.03.2013].

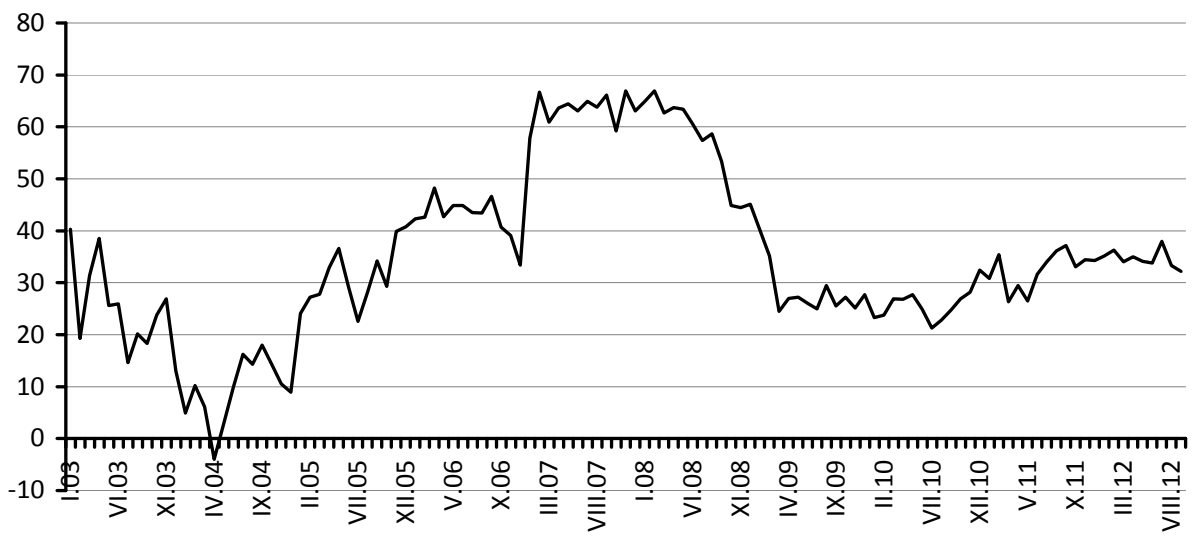

Rys. 5.12. Koniunktura w sekcji Działalność Finansowa i Ubezpieczeniowa Źródło: opracowanie własne na podstawie GUS, www.stat.gov.pl [10.03. 2013].

Bardzo korzysta sytuacja występuje w sekcji działalność finansowa i ubezpieczeniowa. Od połowy 2004 r. wskaźnik ogólnego klimatu koniunktury kształtuje się na dodatnim poziomie. Prognozy dotyczące popytu, sprzedaży i sytuacji finansowej na najbliższe miesiące także są korzystne. W październiku $2012 \mathrm{r}$. wskaźnik wyniósł plus 24, we wrześniu wynosił plus 25 . Z badań przeprowadzonych przez Katedrę Badań Marketingowych Uniwersytetu Ekonomicznego w Poznaniu (Garczarczyk 2009) wynika, że w latach 1992-2009 na polskim rynku finansowym występowały silne wahania koniunktury, przy czym więcej było okresów z rosnącym tempem wzrostu niż z malejącym. Rozgraniczając sektor bankowy i sektor ubezpieczeniowy, w analizowanym okresie tempo rozwoju 
sektora bankowego było wyraźnie wyższe niż sektora ubezpieczeniowego, niemniej jednak przebieg wahań koniunktury był w obu sektorach zbliżony, co wyrażało się zgodnością punktów zwrotnych, faz cyklu, czasu ich trwania oraz ich amplitudy.

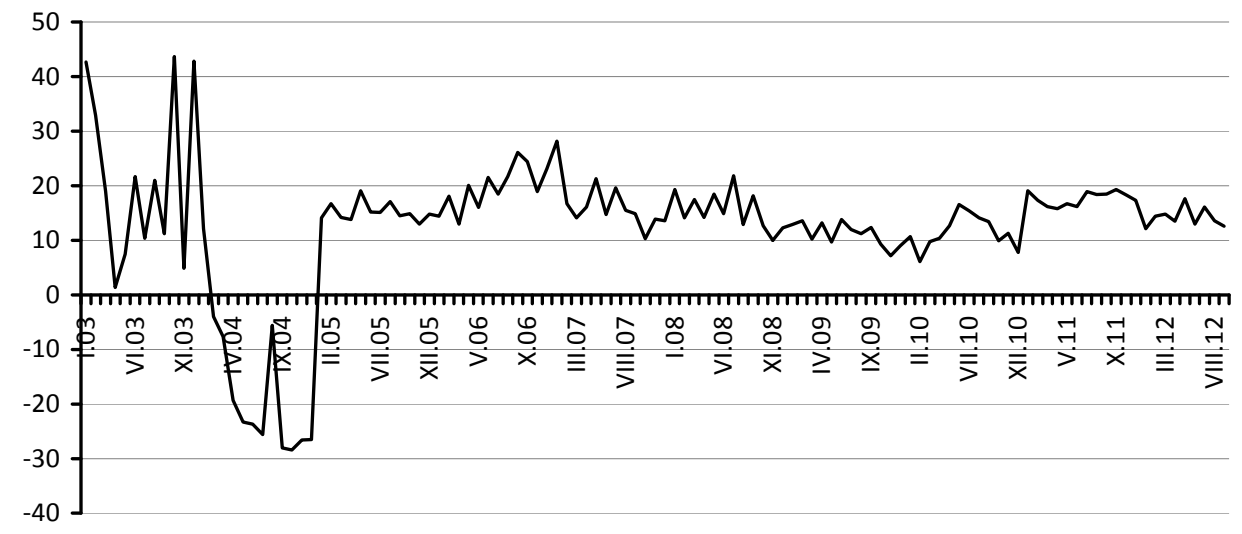

Rys. 5.13. Koniunktura w sekcji Działalność Związana z Obsługą Rynku Nieruchomości Źródło: opracowanie własne na podstawie danych GUS, www.stat.gov.pl [10.03.2013].

Od 2005 r. w działalności związanej z obsługą rynku nieruchomości panuje dość stabilna sytuacja. Wskaźnik ogólnego klimatu koniunktury dla tej sekcji we wrześniu 2012 r. także kształtowała się na dodatnim poziomie.

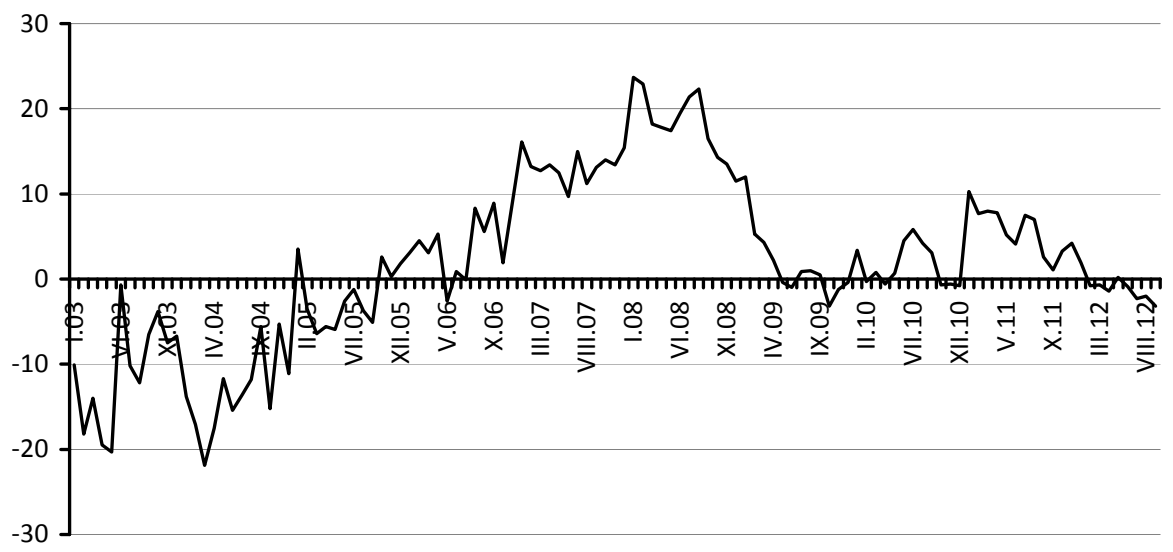

Rys. 5.14. Koniunktura w sekcji Działalność Profesjonalna, Naukowa i Techniczna Źródło: opracowanie własne na podstawie danych GUS, www.stat.gov.pl._[10.03.2013]. 
Po okresie dobrej koniunktury panującej od połowy roku 2006 do połowy 2009 r., wskaźnik koniunktury w sekcji działalność profesjonalna, naukowa i techniczna przyjął niekorzystny wymiar, następnie nastąpił niewielki wzrost, przy czym w ostatnich miesiącach 2012 r. obserwujemy załamanie koniunktury.

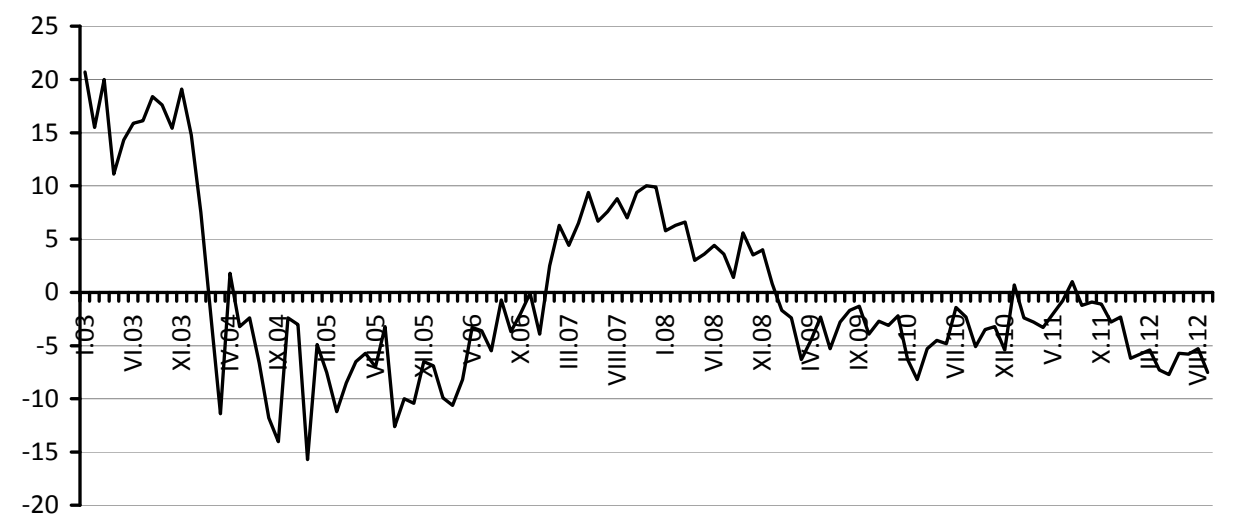

Rys. 5.15. Koniunktura w sekcji Działalność w Zakresie Usług Administrowania i Działalność Wspierająca

Źródło: opracowanie własne na podstawie danych GUS, www.stat.gov.pl [10.03.2013].

W przypadku działalności w zakresie usług administrowania i działalności wspierającej od połowy roku 2011 obserwujemy ujemne wartości wskaźnika ogólnego klimatu koniunktury, we wrześniu 2012 r. sytuacja w tej sekcji również nie uległa poprawie.

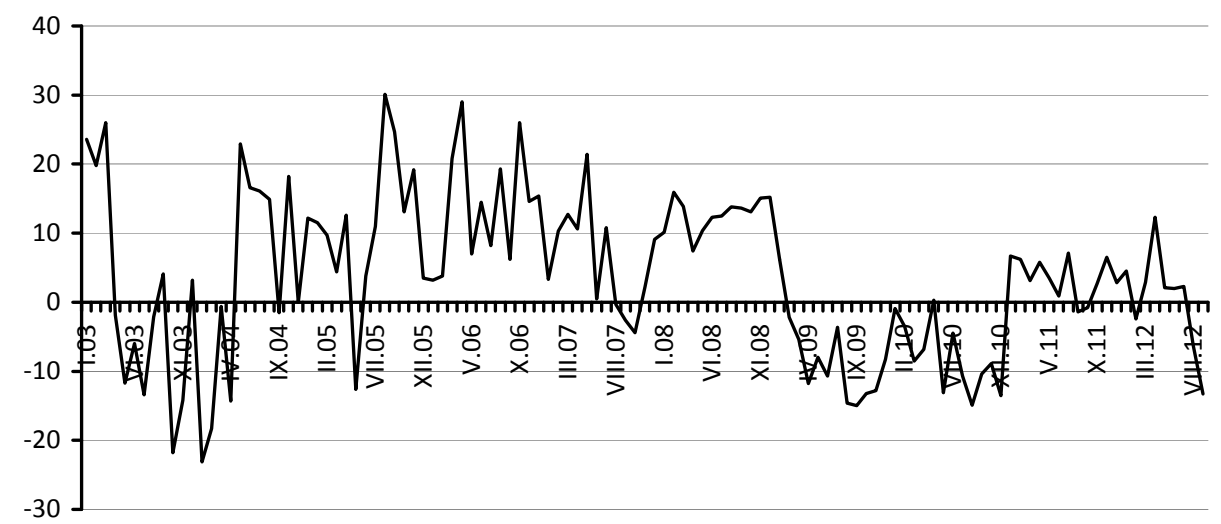

Rys. 5.16. Koniunktura w sekcji Edukacja

Źródło: opracowanie własne na podstawie danych GUS, www.stat.gov.pl_[10.03.2013]. 
W sekcji edukacja bieżąca sytuacja nie napawa optymizmem. Wartość ogólnego wskaźnika koniunktury we wrześniu była ujemna.

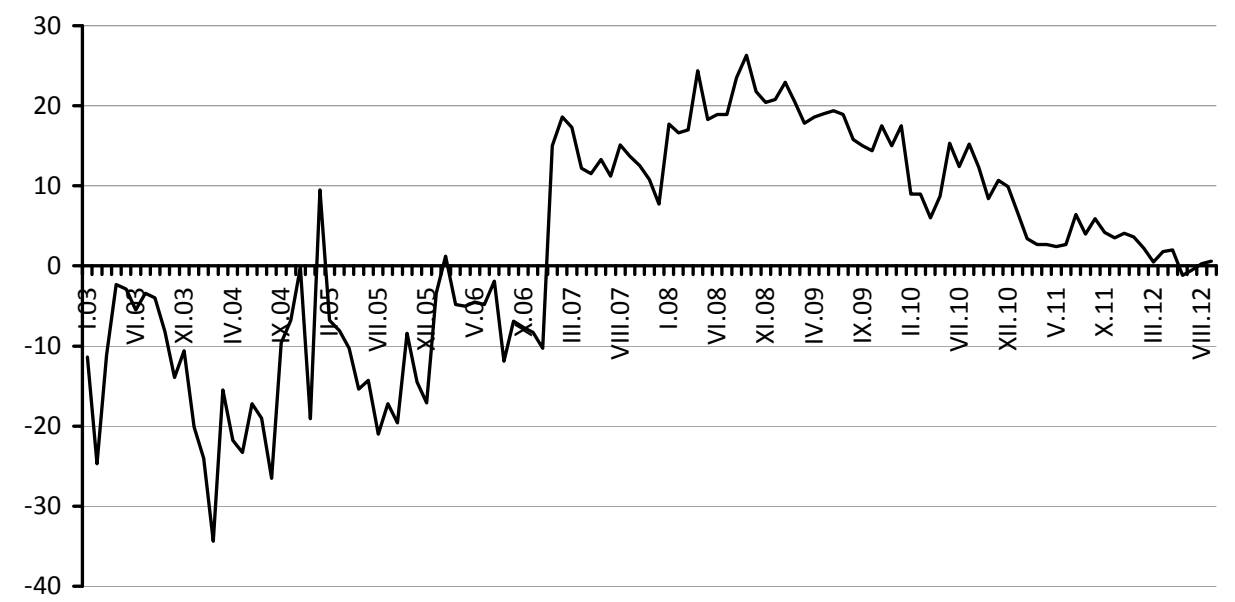

Rys. 5.17. Koniunktura w sekcji Opieka Zdrowotna i Pomoc Społeczna

Źródło: opracowanie własne na podstawie danych GUS, www.stat.gov.pl [10.03.2013].

Wskaźnik ogólnego klimatu koniunktury dla opieki zdrowotnej i pomocy społecznej także nie jest korzystny. Korzystna koniunktura była obserwowana w latach 2007-2011, obecnie wskaźnik wykazuje tendencje malejące.

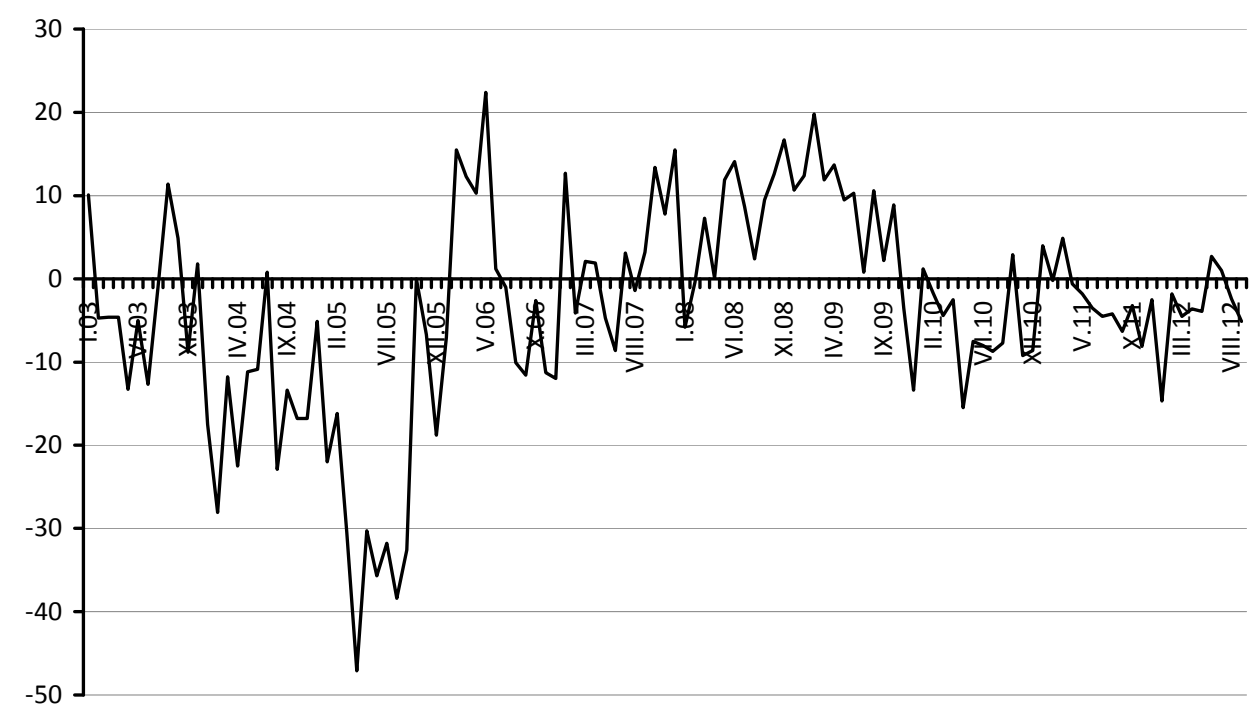

Rys. 5.18. Koniunktura w sekcji Działalność Związana z Kulturą, Rozrywką i Rekreacją Źródło: opracowanie własne na podstawie danych GUS, www.stat.gov.pl [10.03.2013]. 
Zarówno we wrześniu, jak i w miesiącach wcześniejszych w sekcji działalność związana z kulturą, rozrywką i rekreacją obserwujemy ujemne wartości wskaźnika ogólnego klimatu koniunktury.

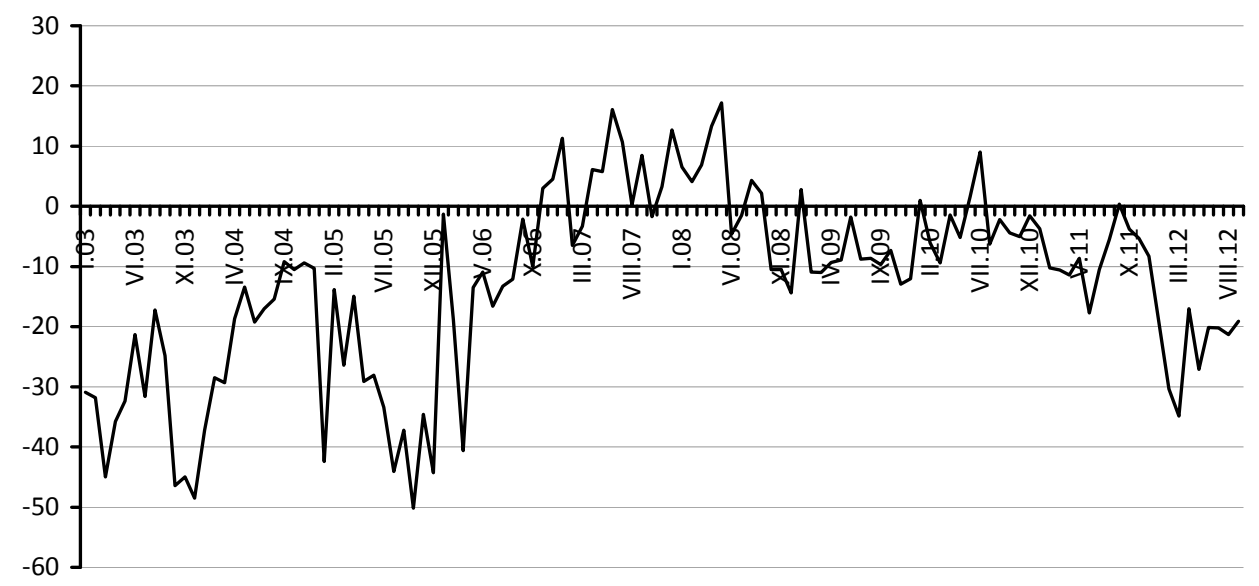

Rys. 5.19. Koniunktura w sekcji Pozostała Działalność Usługowa

Źródło: opracowanie własne na podstawie danych GUS, www.stat.gov.pl [10.03.2013].

Sekcja określana jako pozostała działalność usługowa od początku okresu badawczego wykazuje największe spadki koniunktury, w latach 2007-2008 koniunktura uległa dużej poprawie, obecnie wskaźnik ogólnego klimatu koniunktury dla tej sekcji pomimo pewnej poprawy nadal $\mathrm{w}$ ostatnich miesiącach jest bardzo niekorzystny i pozostaje na ujemnym poziomie.

Badania koniunktury sektora usług obok oceny bieżącej sytuacji podmiotów usługowych koncentrują się także na prognozie na kolejne trzy miesiące. Prognoza dotyczy popytu na usługi, sprzedaży, sytuacji finansowej jednostek usługowych, cen świadczonych usług oraz zatrudnienia. Analizując prognozy dotyczące popytu najgorzej wypada sekcja zakwaterowanie i gastronomia, natomiast bardzo optymistyczne prognozy są dla sekcji działalność finansowa i ubezpieczeniowa. Pesymistyczne prognozy dotyczą sprzedaży, tutaj także najgorsze prognozy dotyczą sekcji zakwaterowanie i gastronomia. Wysoki wzrost sprzedaży prognozują podmioty z sekcji działalność finansowa i ubezpieczeniowa oraz z sekcji informacja i komunikacja. Pesymistyczne prognozy odnośnie sytuacji finansowej oprócz sekcji zakwaterowanie i gastronomia dotyczą także sekcji opieka zdrowotna i pomoc społeczna. Duży optymizm jest przewidywany w stosunku do firm należących do sekcji działalność finansowa i ubezpieczeniowa, a w nieco mniejszym wymiarze do podmiotów sekcji informacja i komunikacja oraz edukacja. Spadek cen prognozowany jest w sekcji informacja i komunikacja, wzro- 
stu cen w okresie najbliższych trzech miesięcy należy się spodziewać w sekcji edukacja. W większości badanych firm usługowych prognozuje się redukcje zatrudnienia, przy czym największych zwolnień należy się spodziewać w sekcji zakwaterowanie i gastronomia oraz w działalności związanej z kultura, rozrywką i rekreacją. Niewielki wzrost zatrudnienia prognozuje się w sekcji edukacja. Prognozując sytuację przedsiębiorstw usługowych w poszczególnych sekcjach ze względu na pięć wybranych wskaźników, najkorzystniejszą sytuację ma sekcja działalność finansowa i ubezpieczeniowa, zła sytuacja ma miejsce w sekcji zakwaterowanie i gastronomia. Słaba koniunktura w Polsce jest odzwierciedleniem niekorzystnej sytuacji gospodarczej w Unii Europejskiej, która zgodnie z przewidywaniami zanotowała ujemny wzrost gospodarczy w II kwartale 2012 r. (-0,2\%).

Kowalewski (2011) na temat przydatności i efektywności testów koniunktury do pomiaru i analizy rynku usług uważa, że istnieją istotne zależności między odpowiedziami na pytania prognostyczne i diagnostyczne podmiotów usługowych, poza tym w ponad połowie podmiotów horyzont czasowy prognozy kształtuje się od 1 miesiąca do 3 miesięcy. Jakość dokonywanych prognoz przede wszystkim zależy od rodzaju podmiotów usługowych w mniejszym zaś stopniu od rodzaju pytania. Najlepsza sprawdzalność prognoz ma miejsce wśród jednostek zaliczanych do sekcji działalność finansowa i ubezpieczeniowa oraz opieka zdrowotna i pomoc społeczna, najsłabiej prognozują jednostki zajmujące się działalnością związaną z kultura, rozrywką i rekreacją oraz zakwaterowaniem i gastronomią. Uważa się, że głównymi przyczynami błędów prognoz są przeszacowanie prognoz oraz nieprecyzyjne prognozowanie punktów zwrotnych.

Miarą określającą poziom koniunktury w sektorze usług jest Indeks PMI (Purchasing Managers Index). Indeks PMI jest uważany za wskaźnik wyprzedzający koniunkturę, określa poziom ryzyka, którym obarczona jest dana branża. PMI uwzględnia wysokość zadłużenia oraz liczbę dni opóźnienia w spłacie należności. Wartość wskaźnika poniżej 50 świadczy o pogarszającej się sytuacji gospodarczej, przekraczająca 50 o dobrej sytuacji gospodarczej, jeżeli wskaźnik osiagnie wartość 100 to będzie to oznaczało, że zachodzące zmiany w gospodarce są pozytywne. W marcu 2013 roku indeks PMI w sektorze usług strefy euro opracowany przez Markit Economics (http://www.macronext.pl/pl/aktualności/ europejskie-indeksy-pmi-dla usług-za-iii-2013) wyniósł 46,4 pkt, w lutym 47,9 pkt. Przyjmuje się, że wartość powyżej 50 punktów oznacza rozwój w sektorze usług. W tym samym okresie wartość indeksu dla Polski wyniosła 48 pkt wobec 48,9. W Hiszpanii było to 45,3 pkt wobec 44,7 pkt, we Włoszech 45,5 pkt wobec 43,6 pkt. Wzrost indeksu PMI zaobserwowano w Wielkiej Brytanii z 52,4 pkt w marcu do 51,8 pkt w lutym. We Francji miał miejsce spadek PMI z 41,3 pkt w marcu wobec 43,7 pkt w lutym. Podobna sytuacja miała miejsce w Niemczech, w marcu indeks wyniósł 50,9 pkt wobec 54,7 pkt w lutym. Dane Markit Economics (http://dev3.uniaeuropejska.org/pmi-w-strefie-euro), dotyczace indeksu 
PMI dla sektora przemysłowego, także nie świadczą o ożywieniu gospodarczym. Wartość indeksu PMI określającego koniunkturę w sektorze przemysłowym dla strefy euro w marcu 2013 roku wyniosła 46,8 wobec 47,9 pkt w lutym. Dla Niemiec było to 49,0 pkt wobec 50,3 pkt, dla Francji 44,0 pkt, wobec 43,9 w lutym. Spadek indeksu PMI wystapił także we Włoszech, w marcu było to 44,5 pkt wobec 45,8 pkt w lutym. W Hiszpanii w marcu indeks wyniósł 44,2 pkt, w lutym było to 46,8 pkt. W Irlandii 48,6 pkt wobec 51,5 pkt, podobnie w Polsce w marcu indeks wyniósł 48 pkt zaś w lutym było to 48,9 pkt. Indeks PMI określający kondycję sektora przemysłowego świadczy o spowolnieniu gospodarczym. Niekorzystna sytuacja występuje zarówno w sektorze usługowym jak i w sektorze przemysłowym. Według OECD złożony wskaźnik wyprzedzający (Composite Leading Indicator CLI) (http://forsal.pl/artykuly/673667, oecd_cli_dla_polski_wzrosl_w_listopadzie_2012_r.html) dla strefy euro w listopadzie 2012 r. wyniósł 99,47 pkt, w październiku wynosił 99,41 pkt. Dla wszystkich państw OECD w listopadzie 2012 r. wyniósł 100,23, w październiku było to $100,17 \mathrm{pkt}$, natomiast w listopadzie 2011 r. 100,06 pkt. Dla Polski w listopadzie 2012 r. CLI wyniósł 100,29 pkt wobec 100,16 pkt w październiku (rosnący CLI o wartości powyżej 100 pkt oznacza ekspansję gospodarki, spadające CLI powyżej poziomu 100 pkt oznacza spadek koniunktury, CLI w trendzie spadkowym i poniżej 100 pkt oznacza spowolnienie, zaś rosnące CLI będące poniżej poziomu 100 pkt oznacza ożywienie (odbudowę) gospodarcze).

W latach 2007-2011 gospodarka polska rozwijała się w wysokim tempie, wykazując najwyższy wzrost w całej Unii Europejskiej (średniorocznie 4,3\% wobec 0,5\% w UE-27), (por. Raport Strategiczny 2012). Ze względu na przewidywania znacznego spowolnienia gospodarczego w UE w latach 2012-2013, także dla Polski zakłada się wzrost PKB nie wyższy niż 2,5\%. Według danych GUS w 2012 roku tempo wzrostu gospodarczego wyniosło 2\% i było najniższe od trzech lat, niższe roczne tempo wzrostu PKB miało miejsce w 2009 roku i wynosiło 1,6\%. Prognozy Instytutu Badań nad Gospodarką Rynkową (IBnGR) także wskazują na spowolnienie rozwoju gospodarczego. Według IBnGR tempo wzrostu PKB w 2013 r. w Polsce wyniesie 1,4\% przy założeniu, że w 2013 r. nastapi dalsze lagodzenie polityki monetarnej NBP oraz tempo wzrostu gospodarczego w Unii Europejskiej w 2013 r. wyniesie około 0,5\%. Słaba koniunktura będzie zauważalna we wszystkich najważniejszych sekcjach polskiej gospodarki. Wartość dodana w przemyśle wzrośnie o około 0,4\%, w budownictwie zmniejszy się o $1,1 \%$, jedynie w sektorze usług rynkowych prognozowany jest wzrost wartości dodanej o 2,4\%. 


\subsection{Koniunktura w województwach}

Powołanie w 1999 r. samorządowych województw, które pod wieloma względami odpowiadają europejskim regionom sprawiło, że nałożono na nie obowiązek realizacji zadań związanych z prowadzeniem polityki rozwoju regionalnego, zmierzającej do poprawy jej konkurencyjności (Wlaźlak 2010). Analiza cykli koniunkturalnych $\mathrm{w}$ województwach pozwala określić stan ich rozwoju gospodarczego. Udział województw w tworzeniu PKB w 2010 roku ilustruje rys. 5.20 .

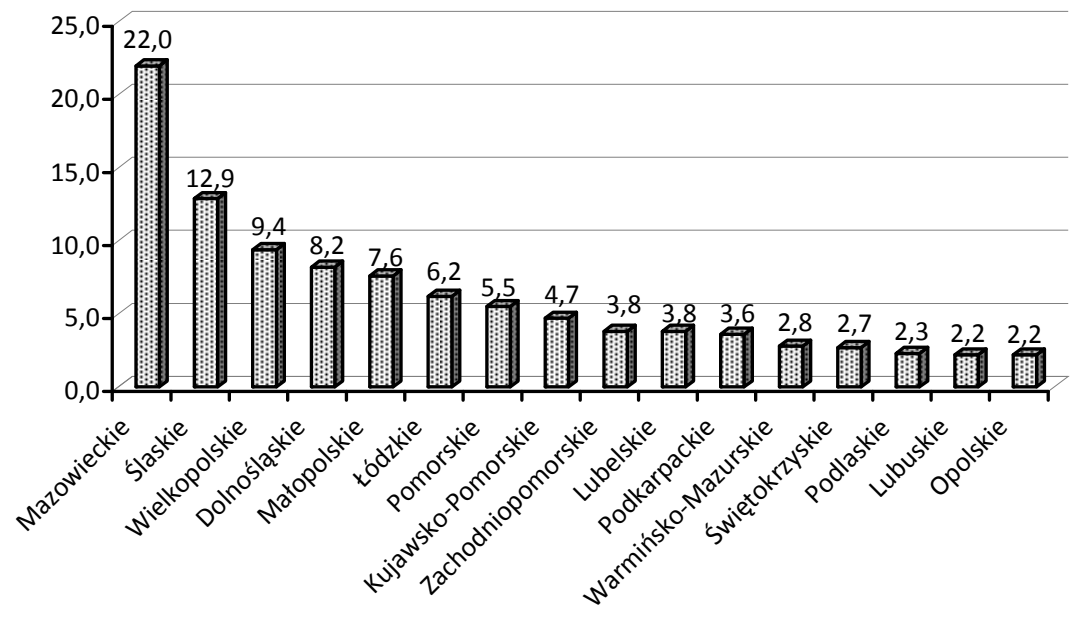

Rys. 5.20. Udział województw w tworzeniu PKB w 2010 r.

Źródło: opracowanie własne na podstawie BIEC (www.biec.org) [10.03. 2013].

Najwyższy udział w tworzeniu PKB wykazuje województwo mazowieckie (22\%), na dużo dalszej pozycji znajduje się województwo śląskie (12,9\%), wielkopolskie $(9,4 \%)$ i dolnośląskie $(8,2 \%)$. Te cztery województwa w 2010 r. wytworzyły łącznie $52,5 \%$ krajowego PKB. Najniższy udział w tworzeniu wartości dodanej brutto wykazuje województwo lubuskie $(2,2 \%)$ i opolskie $(2,2 \%)$. Szacunki wartości produktu krajowego brutto na jednego mieszkańca na poziomie województw podaje tab. 5.20. 
Tablica 5.20. Szacunki wartości produktu krajowego brutto na jednego mieszkańca na poziomie województw ( $\mathrm{w}$ zl)

\begin{tabular}{|l|c|c|c|c|c|c|c|}
\hline $\begin{array}{c}\text { Nazwa wojewódz- } \\
\text { twa }\end{array}$ & $\begin{array}{c}2001- \\
2003\end{array}$ & $\begin{array}{c}2002- \\
2004\end{array}$ & $\begin{array}{c}2003- \\
2005\end{array}$ & $\begin{array}{c}2004- \\
2006\end{array}$ & $\begin{array}{c}2005- \\
2002\end{array}$ & $\begin{array}{c}2006- \\
2008\end{array}$ & $\begin{array}{c}2008- \\
2010\end{array}$ \\
\hline Polska & 20560 & 22453 & 24019 & 25927 & 28146 & 30711 & 35267 \\
\hline Dolnośląskie & 21186 & 23023 & 24619 & 27000 & 29975 & 33098 & 38708 \\
\hline $\begin{array}{l}\text { Kujawsko- } \\
\text { pomorskie }\end{array}$ & 18657 & 20225 & 21293 & 22800 & 24525 & 26676 & 29944 \\
\hline Lubelskie & 14469 & 15733 & 16651 & 17714 & 19095 & 20970 & 24002 \\
\hline Lubuskie & 18040 & 19762 & 21322 & 23199 & 25108 & 26931 & 30035 \\
\hline Łódzkie & 18647 & 20645 & 22097 & 23816 & 25853 & 28344 & 32477 \\
\hline Małopolskie & 17715 & 19236 & 20533 & 22255 & 24185 & 26482 & 30233 \\
\hline Mazowieckie & 31351 & 34456 & 37340 & 40694 & 44871 & 48855 & 56580 \\
\hline Opolskie & 16796 & 18456 & 19881 & 21491 & 23101 & 25445 & 28856 \\
\hline Podkarpackie & 14766 & 15768 & 16770 & 17900 & 19214 & 20985 & 24070 \\
\hline Podlaskie & 15699 & 17039 & 17962 & 19175 & 20789 & 22576 & 25783 \\
\hline Pomorskie & 20312 & 22134 & 23544 & 25434 & 27693 & 29841 & 33883 \\
\hline Ślaskie & 22702 & 24744 & 26341 & 28165 & 30017 & 32795 & 37858 \\
\hline Świętokrzyskie & 16093 & 17412 & 18401 & 19700 & 21381 & 23878 & 27408 \\
\hline $\begin{array}{l}\text { Warmińsko- } \\
\text { mazurskie }\end{array}$ & 15547 & 17425 & 18636 & 19835 & 21225 & 22927 & 25988 \\
\hline Wielkopolskie & 21448 & 23688 & 25561 & 27614 & 29699 & 32160 & 37009 \\
\hline $\begin{array}{l}\text { Zachodniopomor- } \\
\text { skie }\end{array}$ & 20198 & 21387 & 22429 & 23901 & 25652 & 27796 & 31137 \\
\hline
\end{tabular}

Źródło: opracowanie własne na podstawie GUS, www.stat.gov.pl [10.02. 2013].

Wskaźnik PKB per capita określający zamożność obywateli najwyższe wartości w całym analizowanym okresie osiaga w województwie mazowieckim. Do najuboższych województw należy zaliczyć województwo: podkarpackie, warmińsko-mazurskie, świętokrzyskie, opolskie i lubelskie. Podane w tab. 5.20 wartości wskaźnika PKB per capita dla poszczególnych województw świadczą o bardzo silnym zróżnicowaniu społeczeństwa ze względu na poziom dobrobytu. Wartość produktu krajowego brutto przypadająca na jednego mieszkańca w latach 2001-2003 oraz 2008-2010 została przedstawiona na rys. 5.21. 

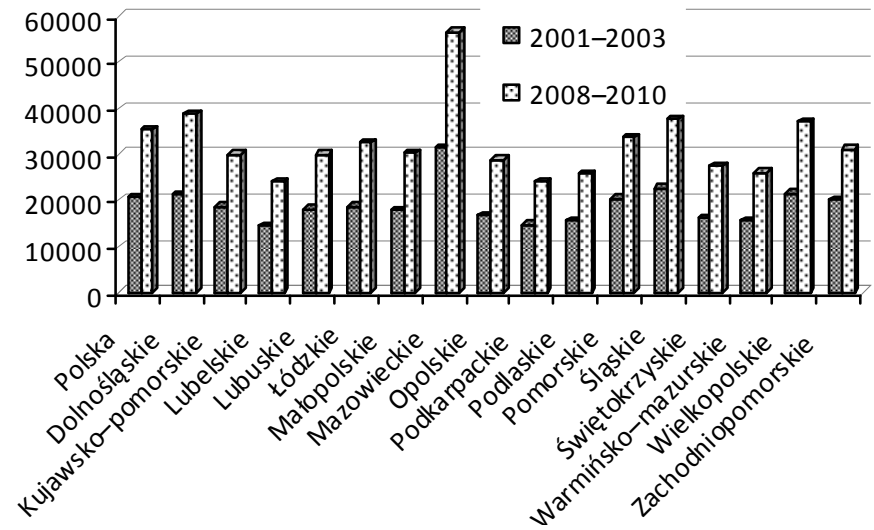

Rys. 5.21. Produkt krajowy brutto na jednego mieszkańca w latach 2001-2003 oraz 2008-2010

Źródło: opracowanie własne na podstawie GUS, www.stat.gov.pl [10.02.2013].

Wartość produktu krajowego brutto przypadającą na jednego mieszkańca w 2009 r. w porównaniu z 2008 i 2007 r. przedstawia rys. 5.22.

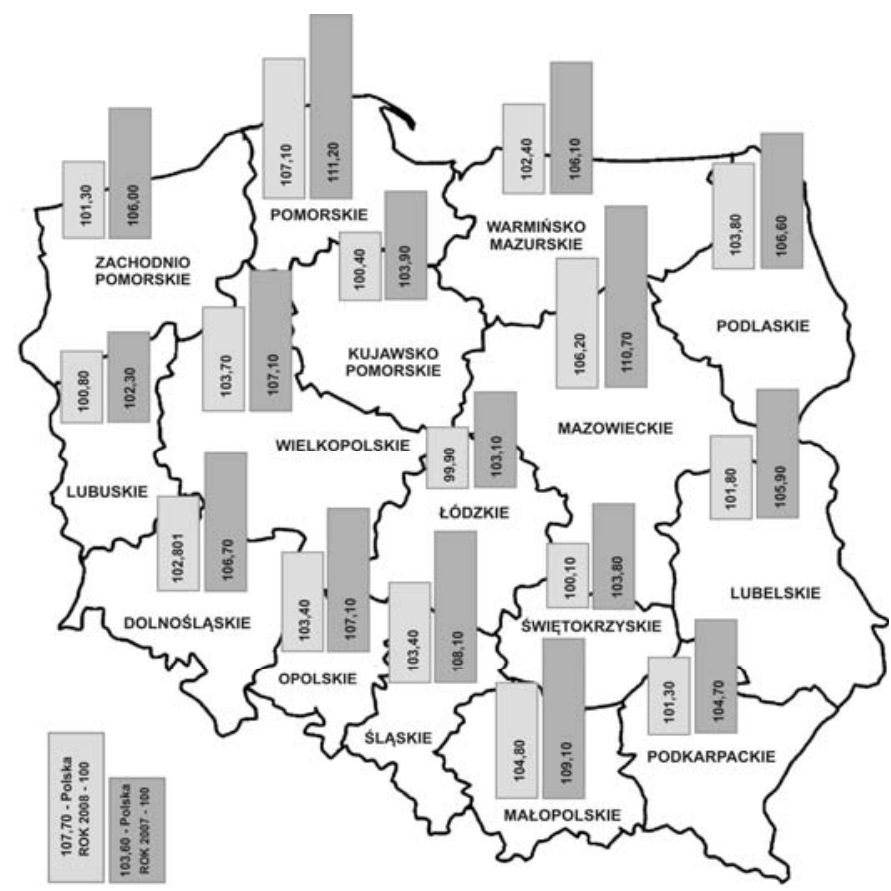

Rys. 5.22. Produkt Krajowy Brutto na jednego mieszkańca w 2009 r.

Źródło: opracowanie własne na podstawie danych GUS, www.stat.gov.pl_[10.02.2013]. 
Dane z rachunków regionalnych za lata 2007-2009 zostały opublikowane w 2011 r., ale są to dane, które po raz pierwszy zostały obliczone w układzie PKD 2007, dlatego słuszne wydało się zwrócenie na nie uwagi (tab. 5.21). W roku 2009 w porównaniu z 2008 dynamika PKB była zróżnicowana, w czterech województwach wystąpił spadek PKB od $0,5 \% \mathrm{w}$ województwie opolskim do $1,2 \%$ w województwie kujawsko-pomorskim, w pozostałych województwach odnotowano wzrost PKB na poziomie od $0,2 \% \mathrm{w}$ województwie lubuskim do $3,9 \% \mathrm{w}$ województwie pomorskim. W roku 2007 największy wzrost PKB miał miejsce w województwie małopolskim (o 9\%), a najmniejszy w województwie opolskim (o 0,2\%), wobec 6,8\% dla kraju ogółem (Produkt Krajowy Brutto..., 2011). Według GUS w latach 2007-2009 województwa mazowieckie, wielkopolskie, podkarpackie i śląskie zwiększyły swoje udziały w tworzeniu PKB, udziały województw: dolnośląskiego, lubuskiego, małopolskiego, podlaskiego, pomorskiego, świętokrzyskiego i warmińsko-mazurskiego nie zmieniły się, natomiast dla pozostałych województw tj.: kujawsko-pomorskiego, lubelskiego, łódzkiego, opolskiego i zachodniopomorskiego uległy zmniejszeniu.

Tablica 5.21. Dynamika PKB według województw

\begin{tabular}{|l|c|c|c|c|c|c|}
\hline \multirow{3}{*}{ Województwa } & \multicolumn{3}{|c|}{ Ogółem } & \multicolumn{3}{c|}{ Na 1 mieszkańca } \\
\cline { 2 - 7 } & 2008 & \multicolumn{2}{|c|}{2009} & 2008 & \multicolumn{2}{c|}{2009} \\
\cline { 2 - 7 } & \multicolumn{2}{|c|}{ rok poprzedni=100 } & $\begin{array}{c}2007= \\
100\end{array}$ & \multicolumn{2}{c|}{ rok poprzedni = 100 } & $\begin{array}{c}2007= \\
100\end{array}$ \\
\hline Polska & 105,1 & 101,6 & 106,8 & 105,1 & 101,5 & 106,7 \\
\hline Dolnośląskie & 105,2 & 101,4 & 106,7 & 105,3 & 101,4 & 106,8 \\
\hline Kujawsko-pomorskie & 104,1 & 98,8 & 102,9 & 104,1 & 98,7 & 102,7 \\
\hline Lubelskie & 106,5 & 99,2 & 105,6 & 106,8 & 99,4 & 106,2 \\
\hline Lubuskie & 105,5 & 100,2 & 105,7 & 105,4 & 100,1 & 105,5 \\
\hline Łódzkie & 106,1 & 100,4 & 106,5 & 106,5 & 100,6 & 107,1 \\
\hline Małopolskie & 106,8 & 102,1 & 109,0 & 106,5 & 101,8 & 108,4 \\
\hline Mazowieckie & 105,3 & 103,3 & 108,8 & 105,0 & 103,0 & 108,2 \\
\hline Opolskie & 100,7 & 99,5 & 100,2 & 101,2 & 99,7 & 100,9 \\
\hline Podkarpackie & 106,8 & 101,3 & 108,2 & 106,8 & 101,1 & 108,0 \\
\hline Podlaskie & 102,8 & 103,1 & 106,0 & 103,0 & 103,2 & 106,3 \\
\hline Pomorskie & 102,6 & 103,9 & 106,6 & 102,2 & 103,4 & 105,7 \\
\hline Śląskie & 106,7 & 100,3 & 107,0 & 107,0 & 100,4 & 107,4 \\
\hline Świętokrzyskie & 106,4 & 99,0 & 105,3 & 106,7 & 99,2 & 105,8 \\
\hline Warmińsko-mazurskie & 104,5 & 102,1 & 106,7 & 104,5 & 102,0 & 106,6 \\
\hline Wielkopolskie & 103,7 & 102,1 & 105,9 & 103,4 & 101,8 & 105,3 \\
\hline Zachodniopomorskie & 102,8 & 102,1 & 105,0 & 102,8 & 102,0 & 104,9 \\
\hline
\end{tabular}

Źródło: Produkt Krajowy Brutto, Rachunki regionalne w 2009 r., GUS, Katowice 2011. 
Na rys. 5.24 został przedstawiony podział województw na cztery grupy, są to województw określane jako: liderzy, regiony doganiające, województwa odstające oraz województwa tracące. Liderzy to województwa o najwyższej dynamice wzrostu PKB, z PKB per capita powyżej średniej krajowej: mazowieckie i śląskie. Województwa te łącznie w latach 2007-2009 wytworzyły ponad 1/3 krajowej wartości PKB (w 2009 r. wytworzyły 35\% PKB, a w 2007 34,7\%). Druga grupa województw to tzw. regiony doganiające o dynamice wzrostu PKB powyżej średniej krajowej oraz niższym od średniej krajowej poziomie PKB per capita, są to województwa: małopolskie, podkarpackie, częściowo warmińskomazurskie, łódzkie i pomorskie. Kolejna grupa określana jako województwa odstające to grupa najliczniejsza, do której możemy zaliczyć: województwa opolskie, kujawsko-pomorskie, podlaskie, lubelskie, lubuskie i zachodniopomorskie. Do grupy województw tracących, czyli o wyższym PKB per capita w stosunku do średniej krajowej niższej od przeciętnej dla kraju dynamice wzrostu, zaliczamy województwo wielkopolskie. Wyznaczone wcześniej miary rozwoju Hellwiga i Perkala (por. rozdz. 3.5) potwierdzają najwyższy rozwój województwa śląskiego i mazowieckiego, wskazały także na znacznie gorszą sytuację w porównaniu z innymi województwami województwa wielkopolskiego. Na najwyższy poziom rozwoju województwa mazowieckiego wskazały także wskaźnik podaży usług oraz wskaźnik nasycenia firmami usługowymi (por. rozdz. 3.5).

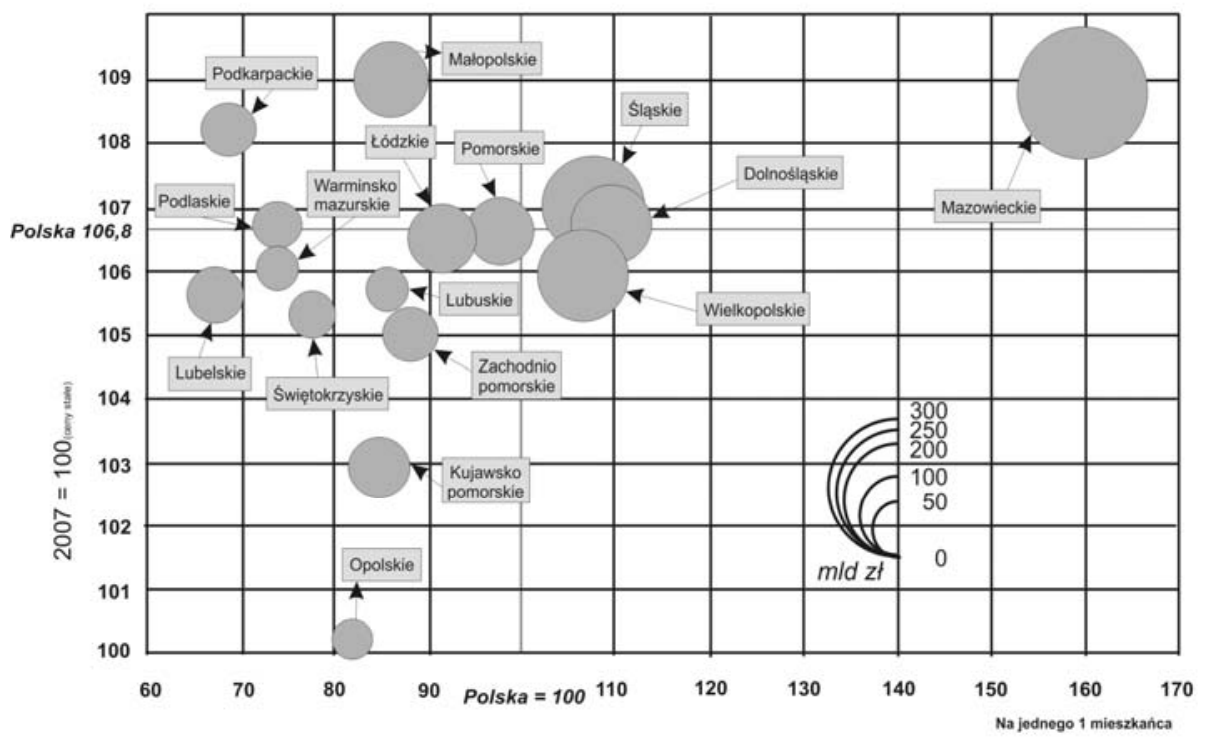

Rys. 5.23. Produkt Krajowy Brutto w 2009 r. $(2007=100)$

Źródło: opracowanie własne na podstawie danych GUS, www.stat.gov.pl [10.02.2013]. 
Analizując sytuację gospodarczą poszczególnych województw, słuszne wydało się zwrócenie uwagi na wskaźniki koniunktury. Wskaźniki koniunktury dla poszczególnych województw (tab. 5.23) zostały poprzedzone wskaźnikami koniunktury gospodarczej dla Polski (tab. 5.22). W tab. 5.22 przedstawiono dane dotyczące wskaźnika bieżącego klimatu koniunktury (WBKK) oraz krótkookresowego prognostycznego wskaźnika koniunktury (KPWK).

Tablica 5.22.Wskaźniki koniunktury gospodarczej dla Polski w drugim półroczu 2012 r.

\begin{tabular}{|l|r|r|r|r|r|r|r|r|r|r|r|r|}
\hline $\begin{array}{c}\text { Sektory } \\
\text { gospodarki }\end{array}$ & $\begin{array}{c}\text { WBKK, } \\
\text { VII }\end{array}$ & KPWK & $\begin{array}{c}\text { WBKK, } \\
\text { VIII }\end{array}$ & KPWK & $\begin{array}{c}\text { WBKK, } \\
\text { IX }\end{array}$ & KPWK & $\begin{array}{c}\text { WBKK, } \\
\text { X }\end{array}$ & KPWK & $\begin{array}{c}\text { WBKK, } \\
\text { XI }\end{array}$ & KPWK & $\begin{array}{c}\text { WBKK, } \\
\text { XII }\end{array}$ & KPWK \\
\hline Ogółem & $-7,4$ & $-3,5$ & $-10,8$ & $-9,9$ & $-7,7$ & $-22,4$ & $-5,0$ & $-19,1$ & $-10,9$ & $-24,4$ & $-23,2$ & $-32,0$ \\
\hline Przemysł & $-5,5$ & 0,6 & $-9,5$ & $-10,2$ & $-2,4$ & $-21,1$ & $-5,1$ & $-23,0$ & $-7,3$ & $-26,1$ & $-23,8$ & $-28,9$ \\
\hline $\begin{array}{l}\text { Handel } \\
\text { i usługi }\end{array}$ & $-13,1$ & $-3,8$ & $-11,8$ & $-6,9$ & -14 & $-20,7$ & $-5,4$ & $-12,5$ & $-15,6$ & $-24,6$ & $-17,9$ & $-32,5$ \\
\hline Banki & 0,6 & $-21,1$ & $-13,3$ & $-16,4$ & $-11,4$ & $-31,4$ & $-3,4$ & $-22,9$ & $-11,9$ & $-17,6$ & $-37,3$ & $-43,8$ \\
\hline
\end{tabular}

Źródło: opracowanie własne na podstawie www.ibngr.pl [10.02.2013].

Według Instytutu Badań nad Gospodarką Rynkową (www. ibngr.pl) w lipcu bieżącego roku najlepiej oceniono koniunkturę w sektorze bankowym, w sierpniu wskaźnik bieżącej koniunktury wyniósł - 10,8, w lipcu było to - 7,4, we wrześniu 7,7 , kolejne miesiące były jeszcze bardziej niepokojące. W grudniu analizowanego roku wyraźnemu pogorszeniu uległa sytuacja w bankach. Niekorzystną wartość osiagnął także wskaźnik wyprzedzający koniunktury, informujący o oczekiwaniach na kolejne trzy miesiące, we wrześniu wyniósł on -22,4. W październiku wskaźnik bieżącej koniunktury uległ niewielkiej poprawie, osiagając wartość $-5,0$, w październiku wskaźnik wyprzedzający wyniósł -19,1, w listopadzie $-24,4$, w grudniu 32,0. Wskaźnik wyprzedzający jest miernikiem określającym panujące $\mathrm{w}$ firmach nastroje, które są złe. W tab. 5.23 zawarto informacje na temat wskaźników koniunktury w województwach.

W lipcu najlepszą koniunkturę gospodarczą zaobserwowano w województwie zachodniopomorskim $(14,9)$, warmińsko-mazurskim $(10,4)$ oraz wielkopolskim $(5,1)$. Najsłabiej wypadło województwo opolskie $(-23,2)$ oraz łódzkie $(-22,7)$. W sierpniu koniunktura gospodarcza województw nadal przedstawiała się niekorzystnie, pozytywnie oceniono tylko koniunkturę w województwie wielkopolskim $(27,5)$, kujawskopomorskim $(20,5)$, podkarpackim $(20,5)$ i zachodniopomorskim $(9,4)$, najsłabiej oceniono koniunkturę w województwie lubelskim $(-29,3)$, dolnośląskim $(-23,7)$ oraz świętokrzyskim $(-20,8)$. We wrześniu pozytywnie oceniono koniunkturę w województwie kujawsko-pomorskim $(19,0)$, podlaskim $(18,3)$, warmińsko-mazurskim $(16,5)$, lubuskim $(15,9)$ i wielkopolskim, w pozostałych województwach wskaźnik bieżącego klimatu koniunktury był niekorzystny, najgorzej oceniono koniunkturę w zachodniopomorskim $(-30,0)$, tódzkim $(-29,4)$ i małopolskim $(-25,2)$. 


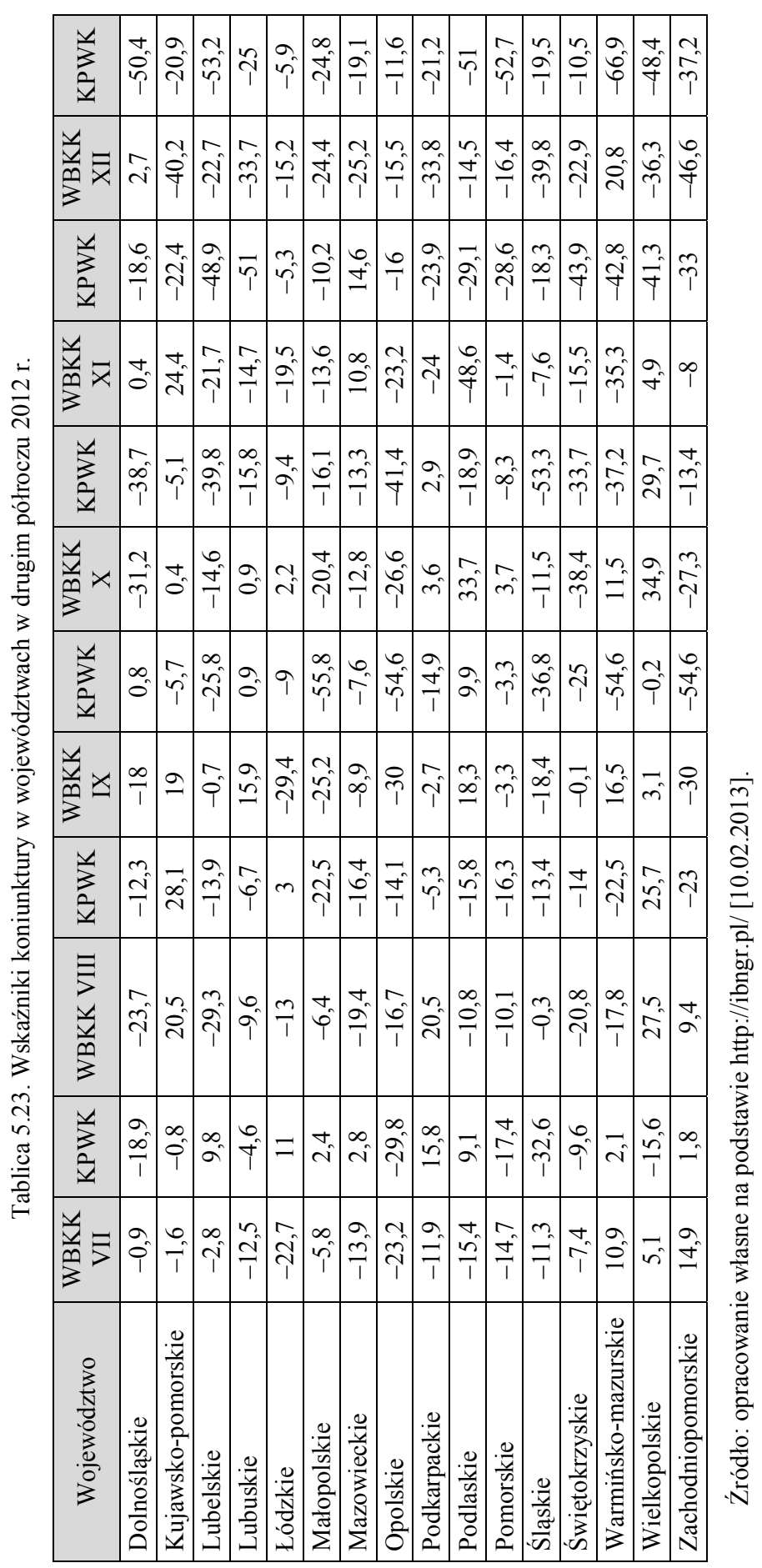


Prognostyczny wskaźnik koniunktury na kolejne trzy miesiące także nie jest optymistyczny. Tylko dla trzech województw krótkookresowy prognostyczny wskaźnik koniunktury ma wartości dodatnie; są to województwa: podlaskie $(9,9)$, lubuskie $(0,9)$ i dolnośląskie $(0,8)$. W październiku w ośmiu województwach koniunktura gospodarcza była pozytywna. W najlepszej sytuacji gospodarczej były województwa: wielkopolskie $(34,90$, podlaskie $(33,7)$, warmińskomazurskie $(11,5)$, pomorskie $(3,7)$, podkarpackie $(3,6)$, lódzkie $(2,2)$, lubuskie $(0,9)$ i kujawsko-pomorskie $(0,4)$. Najsłabsze wyniki osiagnęło województwo: świętokrzyskie $(-38,4)$, dolnośląskie $(-31,2)$, zachodniopomorskie $(-27,3)$, opolskie $(-26,6)$, małopolskie $(-20,4)$, lubelskie $(-14,6)$, mazowieckie $(-12,8)$ i śląskie $(-11,5)$. Porównując krótkookresowy prognostyczny wskaźnik koniunktury na najbliższe trzy miesiące, jedynie w dwóch województwach zaobserwowano dodatnie wartości wskaźnika, są to województwo: wielkopolskie $(29,7)$ i podkarpackie $(2,9)$. Najgorsze prognozy zanotowano dla województwa: śląskiego $(-53,3)$ i opolskiego $(-41,4)$. W listopadzie wskaźnik bieżącego klimatu koniunktury oceniono pozytywnie w województwie kujawsko-pomorskim $(24,4)$, mazowieckim $(10,8)$, wielkopolskim $(4,9)$ i dolnośląskim $(0,4)$. Najsłabiej oceniono koniunkturę $\mathrm{w}$ województwie podlaski $(-48,6)$ i warmińskomazurskim $(-35,3)$.Prognostyczny wskaźnik koniunktury był korzystny tylko dla województwa mazowieckiego. $\mathrm{W}$ grudniu sytuacja nie uległa poprawie, tylko w dwóch województwach koniunktura była oceniana pozytywnie, były to województwo warmińsko-mazurskie $(20,8)$ i dolnośląskie $(2,7)$. W żadnym województwie nie zaobserwowano optymistycznych prognoz na kolejne trzy miesiące.

Według Instytutu Badań Strukturalnych (http://www.ibs.org.pl) większość wskaźników koniunktury świadczy o spowolnieniu gospodarczym w Polsce. Nastapił spadek tempa wzrostu gospodarczego do 2,5\%, zaś stopa bezrobocia odnotowana w II kwartale 2012 r. była najwyższa od 5 lat. Prognozy Europejskiego Banku Centralnego wskazują na utrzymywanie się niskiego tempa wzrostu gospodarczego oraz wysokiego bezrobocia do co najmniej 2014 r. Przewiduje się, że średnioroczna dynamika realnego PKB w 2012 r. wyniesie między $-0,6$ a $-0,2 \%$, zaś w 2013 r. należy się spodziewać, że wyniesie między $-0,4$ a 1,4\% (www.ecb.europa.eu). Wszystkie przytoczone prognozy, zarówno te oparte na badaniach własnych, jak i prognozy sporządzone przez instytuty specjalizujące się w tej dziedzinie, wskazują, że najbliższe miesiące będą trudne, a poprawy zaistniałej sytuacji należy się spodziewać w drugim półroczu 2013 r.

\subsection{Uwagi końcowe}

Rozważania w niniejszym rozdziale koncentrowały się wokół problematyki związanej z prognozowaniem udziału sektora usług w gospodarce. Za pomocą metod statystycznych wyznaczono prognozy udziału wartości dodanej brutto 
w sektorze usług w Polsce. Uzyskane prognozy pozwalają zaobserwować dalszy wzrost tego wskaźnika w analizowanym sektorze.

W celu uzyskania informacji o zmianach sytuacji gospodarczej wykorzystano barometry koniunktury. Przeprowadzona analiza Wskaźnika Równoległego Koniunktury i Wskaźnika Wyprzedzającego Koniunktury za lata 1990-2012 pozwoliła zaobserwować brak tendencji wzrostowej wśród obu wskaźników. Z przebiegu wskaźników możemy wnioskować o braku możliwości zwiększenia wzrostu gospodarczego, należy raczej oczekiwać utrzymania się dotychczasowej skali wzrostu na poziomie roku 2010.

Badając koniunkturę w sektorze usług, zauważono, że w czwartym kwartale 2012 r. koniunktura w sektorze usług w większości przedsiębiorstw była niekorzystna. Badania koniunktury, koncentrujące się na prognozie na kolejne trzy miesiące, także nie są optymistyczne. Analizując prognozy ze względu na popyt na usługi, sprzedaż, sytuację finansową jednostek usługowych, ceny świadczonych usług oraz zatrudnienie. Najbardziej pesymistyczne prognozy dotyczą sekcji zakwaterowanie i gastronomia, zaś najkorzystniejsze prognozy są dla działalności finansowej i ubezpieczeniowej.

Analiza wskaźników koniunktury w układzie województw pozwoliła określić stan ich rozwoju. W ostatnich miesiącach 2012 r. zarówno wskaźnik bieżącego klimatu koniunktury, jak i krótkookresowy prognostyczny wskaźnik koniunktury osiągnęły niekorzystne wartości. Rozważane wskaźniki koniunktury świadczą o spowolnieniu gospodarczym w Polsce. 



\section{ZAKOŃCZENIE}

W rozprawie podjęto próbę oceny rozwoju sektora usług wykorzystując wskaźniki ekonomiczne oparte na zaawansowanych metodach statystycznych. Przeprowadzone badania i uzyskane na ich podstawie wyniki pozwoliły na sformułowanie następujących wniosków w odniesieniu do celów rozprawy sformułowanych we wstępie.

1. Badania dowodzą słuszności teorii trzech sektorów, według której kraje lub regiony znajdujące się na wyższych etapach rozwoju charakteryzują się wysokim udziałem sektora usługowego, umiarkowanym udziałem sektora przemysłowego i niewielkim udziałem sektora rolniczego. W gospodarce polskiej zaobserwowano zgodnie $\mathrm{z}$ tą teorią przeobrażenia polegające na zmniejszeniu roli sektora rolnego i przemysłowego oraz wzroście znaczenia sektora usługowego.

2. Sektor usług jest sektorem dominującym w polskiej gospodarce, świadczy o tym jego przeważający udział w wytwarzaniu wartości dodanej oraz rosnący udział zatrudnienia w tym sektorze. W 1994 roku na sektor rolny przypadało 8\% wartości dodanej brutto, na sektor przemysłowy $40 \%$, zaś na usługi $52 \%$, w roku 2011 proporcje te uległy zmianom, na sektor rolny przypadało około $4 \%$, przemysłowy 33\% i usługowy 63\%. Udział pracujących w $1994 \mathrm{r}$. w sektorze rolnym wynosił $27 \%$, przemysłowym $31 \%$ i usługowym $42 \%$, w 2011 r. wartości te także uległy wyraźnym zmianom, udział pracujących w sektorze rolniczym spadł do $17 \%$, pracujących w przemyśle do $27 \%$, natomiast udział pracujących w usługach wzrósł do $56 \%$. Wzrost udziału sektora usług w wytwarzaniu wartości dodanej brutto i zatrudnieniu był systematyczny, ale dość powolny, co wpłynęło na różnice rozwojowe w porównaniu z innymi krajami Unii Europejskiej

3. Udział poszczególnych sekcji usługowych w tworzeniu wartości dodanej brutto i poziomie zatrudnienia jest wysoce zróżnicowany. Wśród sekcji usługowych pod każdym względem dominuje handel i naprawy. W 2010 r., udział tej sekcji w wartości dodanej brutto ogółem w sektorze usług wynosił 30,52\%, na drugim miejscu był transport, gospodarka magazynowa i łączność z wartością $9,36 \%$. Najniższy udział w 2010 r. wykazały gospodarstwa domowe zatrudniające pracowników oraz wytwarzające produkty na własne potrzeby, było to $0,82 \%$, niski udział charakteryzował także działalność związaną z kultura, rozrywką i rekreacją $(1,31 \%)$ oraz zakwaterowanie i gastronomie $(1,93 \%)$. Podobnie kształtowała się sytuacja w udziale pracujących według sekcji w pracujących ogółem. Najwyższy udział, 27,51\% w 2010 r. wykazał handel i naprawy, na- 
stępnie opieka zdrowotna i pomoc społeczna - 9,61 oraz transport, gospodarka magazynowa i łączność - 8,82\%. Najniższy udział pracujących zaobserwowano w działalności związanej z kultura, rozrywką i rekreacją - 1,87\%. Niskim udziałem, poniżej 3\% charakteryzowała się także działalność związana z zakwaterowaniem i gastronomią oraz informacja i komunikacja.

4. Zastosowanie analizy czynnikowej potwierdziło istotne znaczenie w ocenie sektora usług wartości dodanej brutto, liczby pracujących i podmiotów gospodarczych. Ponadto wykazano jednocześnie, że w rozwoju sektora usług duże znaczenie mają nakłady na działalność badawczą i rozwojową oraz nakłady inwestycyjne.

5. Zastosowanie metody wzorca rozwoju Hellwiga i Perkala umożliwiło dokonanie oceny poszczególnych województw z punktu widzenia rozwoju sektora usług.

6. Uwzględniając udział sektora usług w wartości dodanej brutto oraz poziomie zatrudnienia wyróżniono trzy grupy województw. Biorąc pod uwagę zatrudnienie najwyższy poziom rozwoju sektora usług utrzymuje się w województwie mazowieckim, zachodniopomorskim i pomorskim (powyżej 60\%). Do drugiej grupy (od 50\% do 60\% zatrudnionych w usługach) zaliczamy województwa: dolnośląskie, śląskie, lubuskie, łódzkie, kujawsko-pomorskie, małopolskie, opolskie, warmińsko-mazurskie i wielkopolskie, a do grupy trzeciej (poniżej 50\%) województwa: podkarpackie, podlaskie, świętokrzyskie i lubelskie. Analizując strukturę wartości dodanej brutto w sektorze usług według województw, do grupy pierwszej (powyżej 65\%) także zaliczamy województwa: mazowieckie, pomorskie, zachodniopomorskie oraz podlaskie i małopolskie. Druga grupa województw (od $60 \%$ do $65 \%$ ) to województwa: dolnośląskie, kujawsko-pomorskie, lubelskie, lubuskie, łódzkie, podkarpackie, warmińsko-mazurskie i wielkopolskie. Województwa: śląskie, świętokrzyskie i opolskie (poniżej 60\%) stanowią grupę trzecią.

7. W 2011 r. udział sektora usług w całkowitej wartości dodanej brutto w państwach Unii Europejskiej był zróżnicowany, dla przykładu dla Francji wynosił około $80 \%$, dla Hiszpanii prawie $72 \%$, dla Niemiec $71 \%$, udział tego sektora w Polsce jest najbliższy wskaźnikowi Niemiec i wynosi $65 \%$. W badaniu obejmującym lata 1994-2011 na rozwój sektora usług ma również wpływ kryzys finansowy, w szczególności w krajach Unii Europejskiej. Obserwując strukturę trójsektorowej gospodarki Niemiec w badanym okresie można zauważyć pewne tendencje polegające na niskim udziale w tworzeniu wartości dodanej brutto rolnictwa (około 1\%) oraz wysokim udziale sektora usług, ale dość stabilnym $(65 \%-71 \%)$ oraz znacznym udziale przemysłu (25\%-31\%). Warto zauważyć, że gospodarka niemiecka jest najbardziej odporna wśród krajów UE na kryzys finansowy, co pozwala prowadzić dalsze badania nad strukturą trójsektorową tej gospodarki. 
8. Sektor usług jest sektorem innowacyjnym, przez co wpływa na konkurencyjność gospodarki. O innowacyjności sektora usług świadczy liczba wdrażanych technologii, liczba wprowadzanych na rynek nowych produktów oraz wielkość wydatków na działalność badawczo-rozwojową. W roku 2010 w porównaniu z 2009 nastąpił wzrost nakładów na działalność innowacyjną o około $30 \%$, a tym samym wzrost udziału przedsiębiorstw innowacyjnych z $16 \%$ w latach 1997-1999 do 22\% w latach 2001-2003. W latach 2004-2006 udział przedsiębiorstw, które wprowadziły przynajmniej jedną innowację w sektorze usług wyniósł $21,2 \%$. Zaobserwowano silny związek między wielkością nakładów na $\mathrm{B}+\mathrm{R}$ a poziomem $\mathrm{PKB}$. Różnice w poziomie nakładów innowacyjnych są silnie zauważalne między słabiej rozwiniętymi województwami ściany wschodniej a lepiej rozwiniętymi województwami zachodnimi. Zauważone dysproporcje $\mathrm{w}$ poziomie rozwoju działalności innowacyjnej w poszczególnych województwach są na tyle znaczące, że można mówić o pewnego rodzaju zacofaniu części regionów. Przyczyną zaistniałej sytuacji jest nierównomierny rozwój gospodarczy poszczególnych województw, zasilany przez różny poziom nakładów na działalność innowacyjną i badawczo-rozwojową.

10. Prognozy udziału wartości dodanej brutto wytwarzanej przez sektor usług wykazały tendencję wzrostową.

11. Analiza Wskaźnika Równoległego Koniunktury i Wskaźnika Wyprzedzającego Koniunktury za lata 1990-2012 pozwoliła zaobserwować brak tendencji wzrostowej wśród obu wskaźników. Z analizy wskaźników możemy wnioskować o braku możliwości zwiększenia wzrostu gospodarczego w najbliższych miesiącach. Koniunktura w sektorze usług w większości przedsiębiorstw oceniana została, jako niekorzystna. Rozważane wskaźniki koniunktury świadczą o spowolnieniu gospodarczym w Polsce.

Na podstawie wyników badań zweryfikowano pozytywnie hipotezę, że sektor usług stymuluje rozwój gospodarki, a jego kondycja stanowi o dynamice rozwoju społeczno-gospodarczego poszczególnych jednostek terytorialnych. Weryfikacji poddano także hipotezy szczegółowe. Hipoteza pierwsza, mówiąca o dominującym charakterze usług w gospodarce trójsektorowej, została zweryfikowana pozytywnie. Druga hipoteza o wzroście podobieństwa w trójsektorowych strukturach pracujących i w tworzeniu wartości dodanej brutto pomiędzy Polską a krajami Unii Europejskiej została potwierdzona częściowo. Polska wykazuje tendencje wzrostowe w porównaniach długookresowych. Uzyskane na podstawie przeprowadzonych badań wyniki potwierdziły hipotezę trzecią mówiącą o występującym zróżnicowaniu w strukturze pracujących i wartości dodanej brutto w układzie województw. Potwierdzona została także hipoteza o innowacyjności, która jest podstawowym czynnikiem rozwoju sektora usług. Badania wykazały, iż województwa o najwyższym poziomie PKB charakteryzują się 
najwyższym poziomem rozwoju usług oraz że sektor usług jest sektorem najbardziej odpornym na wahania koniunktury.

W rozprawie wykazano, że ocena rozwoju sektora usług powinna być dokonywana w trzech przekrojach, tzn. poprzez porównania trójsektorowe, regionalne i międzynarodowe, ze względu na wartość dodaną brutto, poziom zatrudnienia i nakłady na działalność innowacyjną.

Podjęto próbę prognozowania rozwoju sektora usług z punktu widzenia wartości dodanej brutto $\mathrm{w}$ najbliższych latach. Jednocześnie pogłębiona analiza sektora usług oparta na wskaźnikach koniunktury świadczy o spowolnieniu gospodarczym i niekorzystnej sytuacji wewnątrz samego sektora.

Analiza przemian ekonomicznych zachodzących w gospodarce światowej dostarcza informacji świadczących o przeważającym udziale sektora usług w strukturach gospodarek państw wysoko rozwiniętych, wskazuje na to wzrost zatrudnienia w tym sektorze, rosnący udział w tworzeniu wartości dodanej brutto, liczba przedsiębiorstw usługowych oraz udział usług w wymianie międzynarodowej. Z przeprowadzonych badań wynika, że sektor usług w Polsce rozwija się bardziej dynamicznie niż cała gospodarka, potwierdza to większy wzrost wartości dodanej brutto wytworzonej w usługach niż ogółem w całej gospodarce. Taka sytuacja może być częściowo efektem niedorozwoju sektora przemysłowego, ale w tym momencie należałoby zastanowić się, czy malejący udział sektora przemysłowego $\mathrm{w}$ strukturze zatrudnienia i wartości dodanej brutto w dłuższym horyzoncie czasowym będzie prowadził do dalszej dominacji sektora usługowego, czy też do jego osłabienia. Uważa się, na co wskazuje między innymi gospodarka niemiecka, że przemysł jest podstawowym sektorem gospodarki a zachodzące w nim przekształcenia mogą świadczyć zarówno o pozycji konkurencyjnej kraju jak i perspektywach rozwoju sektora usług. Wiele rodzajów usług, na co wskazywano we wcześniejszych rozważaniach, jest powiązanych z przemysłem, występowanie wzajemnych zależności sprawia, że pomiędzy sektorem przemysłowym a usługowym dochodzi do wzajemnych interakcji. Znaczący procent zatrudnionych w sektorze usług jest ściśle związany z przemysłem. Może to mieć miejsce zarówno na etapie projektowania, badania opinii konsumenckich, jak i etapie marketingu, serwisowania produktu lub innym.

W państwach wysoko rozwiniętych, stosujących wysokie technologie (Stany Zjednoczone, Japonia), pojawia się problem jednoznacznej klasyfikacji przedsiębiorstw do odpowiedniego sektora gospodarki, co wynika $\mathrm{z}$ wzajemnego przenikania i uzupełniania różnych form działalności. Wytwarzanie coraz bardziej złożonych dóbr wpływa na dostarczanie większej liczby usług. W działalność usługową angażuje się coraz większa liczba przedsiębiorstw z sektora przemysłowego oraz rolniczego. Ograniczanie roli przemysłu w gospodarce, w dalszej perspektywie może wpływać na spadek zapotrzebowania na usługi. Pomimo wielu wątpliwości dominacja sektora usług może być dowodem, że 
struktura polskiej gospodarki przybliża nas do krajów rozwiniętych i rozwija się zgodnie z tendencjami światowymi. Należy jednak zauważyć, że dynamika zachodzących zmian w strukturze polskiej gospodarki jest znacznie mniejsza niż w krajach wysoko rozwiniętych. Dalszy rozwój sektora usług powinien przebiegać w kierunku modelu gospodarki opartej na wiedzy, który w perspektywie czasu umożliwiłby osiagnięcie przewagi konkurencyjnej.

Szczegółowa analiza sektora usług wskazała na kilka problemów badawczych, które wymagają dalszych badań:

1. Badanie rozwoju sektora usług $\mathrm{w}$ ujęciu regionalnym ze szczególnym uwzględnieniem tych sekcji, które wykazują największy wpływ na rozwój.

2. Z punktu widzenia konkurencyjności gospodarek krajów Unii Europejskiej konieczne wydaje się badanie innowacyjności sektora usług w znacznie szerszym zakresie, przy jednoczesnej analizie sygnałów kryzysu w krajach Unii Europejskiej.

3. Ze względu na niepewność i zmienność zjawisk gospodarczych słuszne wydaje się kontynuowanie badania koniunktury w sektorze usług i monitorowanie oraz porównanie ze wskaźnikami innych sektorów. 



\section{LITERATURA}

American Marketing Definitions Committee on Terms (1960), Marketing Definitions:

A Glossary of Marketing Terms, American Marketing Association, Chicago.

Adach-Stankiewicz E., Matulska-Bachura A. (2012), Statystyka ustug w pracach Grupy Voorburg, „Wiadomości Statystyczne”, nr 2, s. 15-23

Adamkiewicz H. G. (2001), Adaptacja rynkowa jako istotny czynnik strategiczny osiqgnięcia sukcesu przez przedsiębiorstwo $w$ warunkach globalizacji, Prace Naukowe Katedry Zarządzania, Wyższa Szkoła Morska, Gdynia.

Anselin L. (1988), Spatial Economeric: Method and Models, Kluwer, Dordrecht.

Badanie Koniunktury Gospodarczej, Zeszyt metodologiczny zaopiniowany przez Komisję Metodologiczną GUS, Wyd. GUS, Warszawa 2010.

Barczyk R., Kowalczyk Z. (1993), Metody badania koniunktury gospodarczej, PWN, Warszawa.

Bell D., (1973), The Coming of Post- Industrial Society. A Venture in Social Forecasting, Basic Books Inc. Publisher, New York.

Blois K.J., (1974), The marketing of services: an approach, „European Journal of Marketing", Vol. 8, less:12, s. 137-145.

Borg I., Groenen P. (2005), Modern Multidimensional Scaling. Theory and Applications, ed. 2, Springer-Verlag, New York.

Brojak-Trzaskowska M. (2012), Determinanty innowacyjnego rozwoju przedsiębiorstw na przykładzie wybranych rodzajów ustug, Wydawnictwo Naukowe Uniwersytetu Szczecińskiego, Szczecin.

Brzeziński Z. (1968), Amerika im technotronischen Zeitalter, [w:] Aus Politik und Zeitgeschichte, Beilage z. Wochenzeitung des Parlament v.29 Mai.

Carp H. J., (1974), Der Transformationsprozess in Dienstleistungs-Unternehmungen, Diss, Berlin.

Cattell, R. B. (1966), The scree test for the number of factors, „Multivariate Behavioral Research", Vol. 1(2), s. 245-276.

Chojnicki Z. (1989), Podstawowe aspekty rozwoju społeczno-gospodarczego, [w:] Współczesne problemy gospodarki przestrzennej polski, red. A. Kukliński A., UW, Warszawa, s. 112.

Choynowski M. (1971), Pomiar w psychologii, [w:] Kozielecki J., (red.), Problemy psychologii matematycznej, PWN, Warszawa.

Cieślak M. (1993), Prognozowanie gospodarcze, Wydawnictwo Akademii Ekonomicznej im. Oskara Langego we Wrocławiu, Wrocław.

Cieślak M. (red.) (2001), Prognozowanie gospodarcze. Metody i zastosowanie, Wydawnictwo Naukowe PWN, Warszawa.

Clark C. (1951), The Conditions of Economic Progress, Mcmillan, London. 
Cyrek M. (2005), Współczesne zmiany struktury sektora ustugowego, [w:] Funkcjonowanie gospodarki polskiej w warunkach integracji i globalizacji, red. D. Kopycińska, Wyd. Katedra Mikroekonomii Uniwersytetu Szczecińskiego, Szczecin, s. 279-289

Cyrek M. (2012), Rozwój sektora ustug a gospodarka oparta na wiedzy, Wydawnictwo Uniwersytetu Rzeszowskiego, Rzeszów.

Czerwińska E. (2003), Ustugi w gospodarce polskiej, Biuro Studiów i ekspertyz, Informacja nr 99.1.

Czerwiński Z. (1982), Matematyczne modelowanie procesów ekonomicznych, PWN, Warszawa.

Daszkowska M. (1982), Ekonomika i organizacja ustug, PWN, Warszawa.

Daszkowska M. (1987), Ustugi w procesie reprodukcji społecznej, Rozprawy i Monografie nr 82, Wydawnictwo Uniwersytetu Gdańskiego, Gdańsk.

Daszkowska M. (1998), Ustugi. Produkcja, rynek, marketing, PWN, Warszawa.

Desai M., Fukuda-Parr S., Johansson C., Sagasti F. (2002), Measuring Technology Achievement of Nations and the Capacity to Participate in the Network Age, „Journal of Human Development”, Vol. 3, No.1, s. 95-122.

Domański Cz., Pruska K., Wagner W. (1998), Wnioskowanie statystyczne przy nieklasycznych założeniach, Wydawnictwo Uniwersytetu Łódzkiego, Łódź.

Domański Cz., (red.), (2001), Metody statystyczne, teoria i zadania, Wydawnictwo Uniwersytetu Łódzkiego, Łódź.

Dostal W. (1988), Informatissierung und Wandel der Berufsstruktur, [w:] Dienstleistungen im Strukturwandel, Berlin, s. 105-122.

Drozdowicz-Bieć M., (2012), Cykle i wskaźniki koniunktury, Wyd. Poltext, Warszawa,

Drucker P.F., (1999), Społeczeństwo pokapitalistyczne, Wydawnictwo Naukowe PWN, Warszawa.

Działalność innowacyjna przedsiębiorstw $w$ sektorze ustug $w$ latach 2001-2003, (2005), GUS Urząd Statystyczny w Szczecinie, Informacje i Opracowania Statystyczne, Warszawa.

Działalność innowacyjna przedsiębiorstw w latach 2004-2006, (2008), GUS, Urząd Statystyczny w Szczecinie, Informacje i Opracowania Statystyczne, Warszawa.

Działalność innowacyjna przedsiębiorstw w latach 2006-2009, (2010), GUS, Urząd Statystyczny w Szczecinie, Informacje i Opracowania Statystyczne, Warszawa.

Działalność innowacyjna przedsiębiorstw w latach 2008-2010, (2011), GUS, Urząd Statystyczny w Szczecinie, Informacje i Opracowania Statystyczne, Warszawa.

Dziuba T., (2010), Sektor informacyjny w badaniach ekonomicznych, Difin, Warszawa.

Europa 2020. Strategia na rzecz inteligentnego i zrównoważonego rozwoju sprzyjajacego wtaczeniu społecznemu, Komisja Europejska, Bruksela 03.03.2010, s. 5.

Everitt B.S. (2002), The Combridge Dictionery of Statistics, Cambrige Uniwersity Press.

Ewolucja sektora ustug w Polsce w latach 1995-2008, (2010), Ministerstwo Gospodarki Departament Analiz i Prognoz, Warszawa.

Fazlagić A. (2001), Zatrudnienie w ustugach, [w:] K. Rogoziński (red.), Transformacja w ustugach. Sektor ustug $w$ Polsce w latach 1990-1999, Wyd. AE w Poznaniu, Poznań, s. 79-80.

Felix B. (2006), Employment in high technology, „Statistics in Fokus”, No. 1. 
Feltynowski M., Nowakowska A. (2009), Metoda oceny potencjału innowacyjnego regionów, [w:] Zdolności innowacyjne polskich regionów, red. A. Nowakowska, Łódź, s. 11-24.

Filipiak B., Panasiuk A. (2008), Przedsiębiorstwo ustugowe Ekonomika, PWE, Warszawa.

Fisher A.G.B. (1933), Capital and the growth of knowledge, „The Economic Journal”, Vol. 43, No. 171, s. 379-389.

Fisher A.G.B. (1935), The economic implication of material progress, „International Labour Review", No. 7, s. 5-19.

Flejterski S., Panasiuk A. Perenc J. Rosa G. (red), (2005), Współczesna ekonomika ustug, Wydawnictwo Naukowe PWN, Warszawa.

Fourastié J. (1954), Die Grosse Hoffnung des zwanzigsten Jahrhundert, Bund-Verlag, Koln-Deutz.

Forbes (07.02.2012), Innowacje w UE: Polska gorzej niż średnia, Axel Springer Polska.

Fuchs V.R. (1965), The Growing Importance of the Service Industries, Occasional Paper 96, National Bureau of Economic Research, Columbia University Press, New York and London.

Fuchs V.R.(1968), The Service Economy, National Bureau of Economic Research, General Series, Number 87, Columbia University Press, New York and London.

Garczarczyk J. (2009), Rynek ustug finansowych a koniunktura gospodarcza, Wyd. CeDeWu, Warszawa.

Garbarski L., Rutkowski I., Wrzosek W. (2000), Marketing - punkt zwrotny nowoczesnej firmy, PWE, Warszawa.

Gatnar E., Walesiak M. (2004), (red.), Metody statystycznej analizy wielowymiarowej w badaniach marketingowych, Wydawnictwo Akademii Ekonomicznej im. Oskara Langego we Wrocławiu, Wrocław.

Gelinger O. (1976), A la decouverte du novveau tertiaire, „Le Monde”, 20.05.1976, za: „Biuletyn Ekonomiczny” PAP, 1976, nr 963.

Giarini O. (1986), Entwuerf zum „Reichtum der Nationen”: Einige Kernpunkte und Definitionen zum Thema Dienstleistungswirtschaft, [w:] Ertel L (Hsrg.), Perspektiven der Dienstlesitum-gswirtschaft, Goettingen.

Gilmore A.(2006), Ustugi. Marketing i zarzqdzanie, PWE, Warszawa.

Godlewska-Majkowska (2010), Zróżnicowanie przestrzenne tworzenia gospodarki ustug w Polsce w latach 1998-2008, [w:] Serwicyzacja polskiej gospodarki, red. I. Lichniak, Oficyna Wydawnicza SGH w Warszawie, Kolegium Nauk o Przedsiębiorstwie, Warszawa, s. 235-255

Gronroos Ch. (1990), Service Management and Marketing, Managing the Moments of Truth in Service Competition, Lexington Books, Lexington, Mass, za: Flejterski R., Klóska M., Majchrzak M., (2005),Wspótczesna ekonomia ustug, Wydawnictwo Naukowe PWN, Warszawa, s. 32-36.

Groonross Ch. (1994), Strategic Management and Marketing In the Service Sector, Studentlitterature, Chartwell-Bratt, Lund.

Grubel H.G., Walker M.A., (1993), Services and the changing economic structure, [w:] Grubel H.G., International Capital and Services Flows. Theory and Measurement for Economic Policy, Vol. II, Economists of the Twentieth Century, University Press, Cambridge. 
Haining R.P. (2003), Spatial Data Analiysis Theory and Practice, Cambridge Uniwersity Press.

Hellwig Z. (1968), Zastosowanie metody taksonomicznej do typologicznego podziału krajów ze względu na poziom ich rozwoju oraz zasoby i strukturę wykwalifikowanych kadr, „Przegląd Statystyczny”, nr 4, s. 307-326.

Hellwig Z. (red.), (1970), Zarys ekonometrii, PWE, Warszawa.

Hill T.P. (1977), On goods and services, „Review of Income and Wealth”, No. 23, s. 318.

Hobson J. A. (1927), The Evolution of Modern Capitalism, London-New York.

Hoowells J. (2000), Innovation and Services. New Cnceptual Frameworks, CRIC Discussion Paper, No 38, August.

Ilnicki D. (2009), Przestrzenne zróżnicowanie poziomu rozwoju usług w Polsce. Teoretyczne i praktyczne uwarunkowania badań, Wydawnictwo Instytut Geografii i Rozwoju Regionalnego Uniwersytetu Wrocławskiego, Wrocław.

Innowacje w sektorze ustug (2010), Polska Agencja Rozwoju Przedsiębiorczości, Warszawa.

Jarmołowicz W (red.), Szarzec K. (2011), Liberalne przesłanki polskiej transformacji gospodarczej, PWE, Warszawa.

Judd R. C. (1964), The case for redefining services, „Journal of Marketing”, January, s. $58-59$.

Kabaj M. (1972), Elementy petnego i racjonalnego zatrudnienia $w$ gospodarce socjalistycznej, KiW, Warszawa.

Kaiser H.F. (2002), An index of taktorial simplicity, „Psyhomertika”, No. 39, s. 31-36.

Karpiński A. (1986), Restrukturyzacja gospodarki w Polsce i na świecie, PWE, Warszawa.

Kasperkiewicz W. (2011), Perspektywy rozwoju innowacyjności polskiej gospodarki, Zeszyty Naukowe nr 9 Polskie Towarzystwo Ekonomiczne, Kraków.

Katouzian M. A. (1970), The development of the service sector. A new approach, „Oxford Economic Papers”, s. 365.

Kierunki zwiększania innowacyjności gospodarki na lata 2007-2013, (2006), Ministerstwo Gospodarki, Warszawa.

Klein L.R., (1982), Wyktady z ekonometrii, PWE, Warszawa.

Kłosiński K. (2002), Międzynarodowy obrót ustugowy, Difin, Warszawa.

Kłosiński K. (2011), Światowy rynek ustug w poczqtkach XXI wieku, PWE, Warszawa.

Kłosiński K. (red), (2009), Ustugi w gospodarce światowej, Instytut Badań Rynku, Konsumpcji i Koniunktur, Warszawa.

Kłosowski F. (2006), Sektor ustug $w$ gospodarce region tradycyjnego $w$ warunkach transformacji $i$ restrukturyzacji. Przykład konurbacji katowickiej, Wydawnictwo Uniwersytetu Śląskiego, Katowice.

Koniunktura gospodarcza świata i Polski w latach 2010-2013. Raporty, (2012), Instytut Badań Rynku, Konsumpcji i Koniunktur, Warszawa.

Koniunktura $w$ przemyśle, budownictwie, handlu i ustugach 2000-2012, (2012), GUS, Warszawa.

Koniunktura $w$ przemyśle, budownictwie, handlu i ustugach $w$ październiku 2012 r., (2012-10-23), GUS, Warszawa. 
Kopczewska K. (2010), Modele zmian stopy bezrobocia w ujęciu przestrzennym, „Wiadomości Statystyczne", nr 5, s. 26-40.

Kopczewska K., Kopczewski T., Wójcik P. (2009), Metody ilościowe w R. Aplikacje ekonomiczne i finansowe, Wydawnictwo CeDeWu, Warszawa.

Kotarbiński T. (1973), Traktat o dobrej robocie, Ossolineum, Wrocław-WarszawaKraków-Gdańsk.

Kotler Ph (1994), Marketing. Analizowanie, planowanie, wdrażanie i kontrola, Gebethner \& Ska, Warszawa.

Kotler Ph., Armstrong G, Saunders J., Wong V. (2002), Marketing. Podręcznik europejski, PWE, Warszawa.

Kowalewski G., (2011), Przydatność testów koniunktury do analiz rynku ustug, [w:] Garczarczyk J. (red.), Metody pomiaru i analizy rynku ustug. Pomiar jakościowy zastosowania i efektywność, Wydawnictwo Uniwersytetu Ekonomicznego w Poznaniu, Zeszyty Naukowe 204, Poznań, s. 50-60.

Kramer T.(1994), Podstawy marketingu, PWE, Warszawa.

Krancke J. (1999) Liberalisierung des internationalen Dienstleistungshandels: Analyse des GATS und Perspektiven für die zukünftigr Handelsliberalisierung, Institut für Weltwirtschaft, Kiel.

Krawiec F. (2000), Zarzqdzanie projektem innowacyjnym produktu i ustugi, Difin, Warszawa.

Kruskal J.B. (1964a), Multidimensional scaling by optymiscing goodness-of-fit to a nonumetric hypothesis, „Bychonetrika”, 29.1-27.

Kruskal J.B. (1964b), Numetric multimensional scaling: a numerical method, „Psychometrika”, No. 29, s. 115-129.

Kruszka M. (2006), Sektor ustug w gospodarce krajów wysoko rozwiniętych, „Wiadomości Statystyczne", nr 11, s. 55-70.

Krzyżanowski W.(1947), Teoria produkcji ustug, „Ekonomista”, kwartał III/ IV, s. 2.

Kuczewska J. (2007), Ocena pozyskiwania środków pomocowych UE dla polskich przedsiębiorstw, [w:] Otto J., Stanisławski R., Maciaszczyk A. (red.), Innowacyjność jako czynnik podnoszenia konkurencyjności przedsiębiorstw i regionów na jednolitym rynku europejskim, Łódź.

Kukliński A. (red), (2003), Gospodarka oparta na wiedzy. Perspektywy Banku Światowego, Biuro Banku Światowego w Polsce, Komitet Badań Naukowych, Warszawa.

Kurek S. (2010), Przestrzenne zróżnicowanie poziomu rozwoju regionalnego $w$ Unii Europejskiej $w$ świetle wybranych mierników, „Prace Komisji Geografii Przemysłu", nr 16, Warszawa-Kraków.

„Kwartalne Prognozy Makroekonomiczne”, nr 75, (2012), Wyd. Instytut Badań nad Gospodarką Rynkowa, Warszawa.

Kwiatkowska W. (2000), Struktura gospodarcza-problemy pojęciowe, [w:] Kwiatkowska W. (red.), Procesy dostosowawcze w gospodarce polskiej w kontekście integracji z Uniq Europejska, Przedsiębiorstwo Specjalistyczne ABSOLWENT Sp. z o. o., Łódź.

Kwiatkowska W. (2007), Zmiany strukturalne na rynku pracy w Polsce, Wydawnictwo Uniwersytetu Łódzkiego, Łódź.

Kwiatkowski E. (1980), Teoria trzech sektorów gospodarki, PWN, Warszawa. 
Kwiatkowski E., Kucharski L. (red.), (2010), Rynek pracy w Polsce - tendencje, uwarunkowania i polityka państwa, Wydawnictwo Uniwersytetu Łódzkiego, Łódź.

Kwiatkowski E., Kucharski L. (2011), Konkurencyjność gospodarki a rozwój gospodarczy-województwo lódzkie na tle innych województw, [w:] Lewandowska L. (red.), Innowatorzy, innowacje a konkurencyjność firm regionu łódzkiego, PTE Oddział w Łodzi, Łódź.

Lange O. (1959), Ekonomia polityczna, t. I, PWN, Warszawa.

Lichniak I. (2010), Serwicyzacja polskiej gospodarki, Oficyna Wydawnicza SGH w Warszawie Kolegium Nauk o Przedsiębiorczości, Warszawa.

Lipiński E. (1965),Wstęp do rozważań nad problematykq usług w ekonomii politycznej socjalizmu, [w:] Ustugi i ich rola społeczno-ekonomiczna, PWE, Warszawa.

List F. (1922), Das nationale System der politischen Oekonomie, Jena.

Lotko A. (2009), Ocena jakości ustug w centrach kontaktu z klientem, Wydawnictwo Naukowe PWN, Warszawa.

Lovelock Ch. (1983), Classifying services to gain strategic marketing insights, „Journal of Marketing", No. 47, s. 9-10.

Łobacz K., Niedzielski P. (2012), Innowacje w sektorze ustug - czy różniq się od innowacji w sektorze przemysłowym?, [w:] Olszański M., Piech K., E-biznes-innowacje w ustugach. Teoria, praktyka, przykłady, Wydawnictwo PARP, Warszawa.

Malarska A. (2005), Statystyczna analiza danych wspomagana programem SPSS, Wydawca SPSS Polska Sp. z o.o., Kraków.

Mały Rocznik Statystyczny Polski 2006, 2012, GUS, Warszawa.

Merkantylizm i poczatki szkoły klasycznej. Wybór pism ekonomicznych XVI i XVII wieku (1958), PWN, Warszawa.

Milewski R., Kwiatkowski E. (red.), (2005), Podstawy ekonomii, Wydawnictwo Naukowe PWN, Warszawa.

Mizgajska H. (2002), Aktywność innowacyjna polskich matych i średnich przedsiębiorstw w procesie integracji z Uniq Europejska, Akademia Ekonomiczna w Poznaniu, Poznań.

Moran P. (1948), The interpretation of statistical maps, „Journal of the Royal Staistical Society", Series B 10, s. 243-251.

Morrison D. F. (1990), Multivariate Statistical Methods, McGraw-Hill Book Co., New York.

Mudie P., Cottam A., (1998), Ustugi. Zarzqdzanie i marketing, Wydawnictwo Naukowe PWN, Warszawa.

Naumowicz K., (1992), Ustugi. Zagadnienia ogólne, Wydawnictwo Uniwersytetu Szczecińskiego, Szczecin.

Niedzielski P. (2003), Polityka innowacyjna $w$ transporcie, Wydawnictwo Naukowe Uniwersytetu Szczecińskiego, Szczecin.

Niedzielski P.(2008), Zarzadzanie innowacjami w przedsiębiorstwach ustugowych, [w:] Filipiak B. (red), Przedsiębiorstwo ustugowe. Zarzadzanie, Wydawnictwo Naukowe PWN, Warszawa.

Niedzielski P., Markiewicz J., Rychlik K., Rzewuski T. (2007), Innowacyjność w dziatalności przedsiębiorstw. Kompendium wiedzy, Wydawnictwo Naukowe Uniwersytetu Szczecińskiego, Szczecin. 
Niedzielski P., Rychlik K., Markiewicz J. (2008), Innowacyjność przedsiębiorstw sektora ustug-nowe ścieżki rozwoju, [w:] Horodyńska E. (red.), Tendencje innowacyjnego rozwoju polskich przedsiębiorstw, Instytut Wiedzy i Innowacji, Warszawa.

Niemcy $w$ zarysie, Informacje $i$ analizy dotyczqce polityki, gospodarki oraz ksztatcenia $w$ Niemczech wraz z podstawowym słownictwem oraz poradami, jak prowadzić negocjacje, Wyd. HAUS RISSEN HAMBURG - Internationales Institut für Politik und Wirtschaft (Międzynarodowy Instytut Polityki i Gospodarki), Hanse-Parlament e.V., http://www.hausrissen.org/.

Niewadzi Cz. (1975), Ustugi w gospodarce narodowej, PWE, Warszawa.

Niewadzi Cz. (1982), Sektor ustug w kapitalizmie, PWN, Warszawa.

Nowa encyklopedia powszechna PWN (2004), Wydawnictwo Naukowe PWN, Warszawa.

Nowosielska E., (1994), Główne tendencje rozwojowe ostatniego dwudziestolecia i aktualne problemy badawcze, ,Zeszyty IGiPZ PAN”, z. 22.

Obłój K. (2004), Strategiczne wyzwania polskich firm, „Przegląd Organizacji”, nr 1, s. $6-8$.

Okulas M. (1998), Ustugi jako czynnik aktywizujacy długofalowy rozwój gospodarki, Instytut Rozwoju Studiów Strategicznych, Warszawa.

Olearnik J., Styś A. (1989), Ustugi w rozwoju społeczno-gospodarczym, PWE, Warszawa.

Olszański M., Piech K. (2012), E-biznes-innowacje w ustugach. Teoria, praktyka, przykłady, Wydawnictwo PARP, Warszawa.

Ostasiewicz W. (red.), (1998), Statystyczne metody analizy danych, Wydawnictwo Akademii Ekonomicznej im. Oskara Langego we Wrocławiu, Wrocław.

Pawłowski T., (1969), Metodologiczne zagadnienia humanistyki, PWN, Warszawa.

Payne A. (1996), Marketing ustug, PWE, Warszawa.

Pluta W. (1977), Wielowymiarowa analiza porównawcza $w$ badaniach ekonomicznych, PWE, Warszawa.

Pluta-Olearnik M.(1993), Marketing ustug, PWE, Warszawa.

Podręcznik Oslo (2008), Zasady gromadzenia i interpretacji danych dotyczacych innowacji, OECD\&Eurostat, wyd. 3, Warszawa.

Polarczyk K. (1971), Wynik pracy podstawa definicji i klasyfikacji ustug oraz sfery ustug, „Ruch Prawniczy, Ekonomiczny i Socjologiczny”, nr 1.

Pomianek I (2010), Poziom rozwoju społeczno-gospodarczego obszarów wiejskich województwa warmińsko-mazurskiego, „Acta Oeconomia”, nr 9 (3), s. 227-239.

Pomykalski A. (2001), Innowacje, Wyd. Politechnika Łódzka, Łódź.

Porat M. U. (1977), The Information Economy, Of Special publication 77-12 Washington, Mai.

Porter M., Stern S. (1999), The New Challenge to America's Prosperity: Findings from the Innovation Index, Council on Competitiveness, Washington, D. C.

Pracujacy w gospodarce narodowej w 2009 r., (2010), GUS, Warszawa.

Produkt Krajowy Brutto Rachunki Regionalne w 2009 r., (2011), GUS, US w Katowicach, Katowice.

Quinn G. P., Keough M. J. (2001), Multidimensional Scaling and Cluster Analysis 577578 in Experimantal Design and Data Analysis for Biologists, Cambridge University Press.

Raport Strategiczny 2012 (2012), Ministerstwo Rozwoju Regionalnego, Warszawa. 
Raport o stanie gospodarki „Polska 2010”, (2010), Ministerstwo Gospodarki, Warszawa. Regan W. (1963), The service revolution, ,Journal of Marketing”, Vol. 27, No. 3.

Rocznik Statystyki Międzynarodowej 2012, GUS.

Rocznik Statystyczny Rzeczypospolitej Polskiej 1997, 2000, 2001, 2005, 2006, 2008, 2011, 2012 GUS.

Rogoziński K., (1993), Ustugi rynkowe, AE, Poznań.

Rogoziński K.(2000), Ustugi rynkowe, Wydawnictwo Akademii Ekonomicznej w Poznaniu, Poznań

Rozkrut M. (2008), Sektor ustug w Polsce w ujęciu regionalnym, [w:] Metody ilościowe w ekonomii, Studia i Prace Wydziału Nauk Ekonomicznych i Zarządzania nr 2, Wydawnictwo Naukowe Uniwersytetu Szczecińskiego, Szczecin.

Rudawska I. (red.), (2009), Ustugi w gospodarce rynkowej, PWE, Warszawa.

Rybak M. (2003), Kapitat ludzki a konkurencyjność przedsiębiorstw, Poltext, Warszawa.

Rynek wewnętrzny w 2005 r. (2006), GUS, Warszawa.

Rynek wewnętrzny w 2007 r. (2008), GUS, Warszawa.

Rynek wewnętrzny w 2011 r. (2012), GUS, Warszawa.

Sadler Ph. (1997), Zarzqdzanie w społeczeństwie postindustrialnym, Profesjonalna Szkoła Biznesu, Kraków.

Schewe Ch. D., Smith R.M., (1980), Marketing, McGraw-Hill Book Company, New York.

Sasser W. E. (1976), Match supply and demand in service industries, „Harvard Business Reviev", Nov.-Dec., s. 13.

Schumpeter J.A. (1960), Teoria rozwoju gospodarczego, PWE, Warszawa.

Skolka J. (1977), Dienstleistungen oder Selbstbedingung, „Wirtschaft und Gesellschaft”, Bd. 4, s. 403.

Skórska A. (2010), Ustugi nasycone wiedza (KIS) jako obszar kreowania miejsc zatrudnienia $w$ Polsce $i$ Unii Europejskiej, [w:] Rynek pracy w Polsce - tendencje, uwarunkowania polityka państwa, red. E. Kwiatkowski, L. Kucharski, Wydawnictwo Uniwersytetu Łódzkiego, Łódź.

Słomińska B. (2009), Szanse rozwoju sekcji usługowych w polskich regionach, [w:] K. Kłosiński (red.), Usługi w gospodarce światowej, Instytut Badań Rynku, Konsumpcji i Koniunktur, Warszawa.

Słomińska B. (2011), (red.), Ustugi w Polsce 2008-2010, Instytut Badań Rynku, Konsumpcji i Koniunktur, Warszawa, s. 140-150.

Smith A. (1954), Badania nad natura i przyczynami bogactwa narodów, PWN, t. I, Warszawa.

Stan i prognoza koniunktury gospodarczej, nr 76 (październik 2012), Wydawnictwo Instytut Badań nad Gospodarką Rynkową, Warszawa.

Skarbek F. (1931), Elementarne zasady gospodarowania narodowego, t. I, Warszawa.

Stanton W.J. (1981), Fundaments of Marketing, McGraw-Hill Book Company, New York.

Styś A., Olearnik J. (1985), Ekonomika i organizacja usług, PWE, Warszawa.

Stefaniak J. (2007), Rola ustug w gospodarce, [w:] Zachowania rynkowe $w$ teorii i praktyce, red. D. Kopycińska, Katedra Mikroekonomii Uniwersytetu Szczecińskiego, Szczecin, s. 98-107. 
Stigler G.J. (1956), Trends in Employment in Service Industrries, Princeton University Press, Princeton.

Surowiecki W (1957), Wybór pism, t. II, PWN, Warszawa.

Szacunek PKB per capita i bezpośrednich inwestycji zagranicznych $w$ województwach oraz wskaźniki wyprzedzajace koniunktury. Ekspertyza wykonana na zlecenie Ministerstwa Rozwoju Regionalnego, Biuro Inwestycji i Cykli Ekonomicznych, Warszawa, maj 2011.

Szczukocka A. (2011a), Rola e-government w rozwoju społeczno-gospodarczym, [w:] Rola informatyki $w$ naukach ekonomicznych i społecznych. Innowacje $i$ implikacje inerdyscyplinarne, red. T. Grabiński, Wydawnictwo Wyższej Szkoły Handlowej, Kielce 2011, s. 165-178.

Szczukocka A. (2011b), Rozwój ustug elektronicznych w Polsce, „Wiadomosci Statystyczne", nr 11, s. 74-75.

Szczukocka A. (2012), Rozwój i funkcjonowanie przedsiębiorstw ustugowych w Polsce, [w:] Czas na pieniadz. Zarzadzanie Finansami. Upowszechnianie i transfer wyników badań, red. D. Zarzecki, Wydawnictwo Uniwersytetu Szczecińskiego, Szczecin 2012, s. 209-218.

Szukalski S.M. (2001), Sektor ustug w gospodarce niemieckiej. Hipotezy i empiryczna weryfikacja przekształceń strukturalnych, Wydawnictwo Uniwersytetu Lódzkiego, Łódź.

Szukalski S. M. (2004), Serwicyzacja gospodarki i industrializacja ustug, „Handel Wewnętrzny", nr 4-5, s. 47-53.

Szukalski S.M. (2007), Wyzwania europejskie w perspektywie 2050 roku - skutki dla rozwoju ustug, [w:] K.A. Kłosiński (red.), Usługi w gospodarce światowej, Instytut Badań Rynku, Konsumpcji i Koniunktur, Ministerstwo Gospodarki, Warszawa, s. 9-18.

Szukalski S. M. (2009), Światowy rynek ustug i perspektywy jego rozwoju $w$ XXI wieku, [w:], K.A. Kłosiński (red.), Ustugi w gospodarce światowej, Instytut Badań Rynku, Konsumpcji i Koniunktur, Warszawa, s. 11-32.

Szymala Z. (2000), Determinanty rozwoju regionalnego, Wrocław.

Szymala Z. (2005), Podstawy badań rozwoju regionalnego, „Zeszyty Naukowe Wyższej Szkoły Ekonomicznej w Bochni”, nr 3, s. 101-111.

Takane Y., Young F.W., de Leeuw J (1977), Nonmetric individual differences in multidimensional scaling: an alternating least squares method with optimal scaling features, „Psychometrika”, No. 42, s. 7-76.

The Global Competitiveness Report 2010-2011, World Economic Forum, Geneva 2011, s. 3-9.

Toffler A. (2001), Trzecia fala, PIW, Warszawa.

Toffler A. (2007), Szok przyszłości, Wydawnictwo Kurpisz, Poznań.

Wagner W. (2002), Podstawy metod statystycznych $w$ turystyce i rekreacji, Wydawnictwo Akademia Wychowania Fizycznego im. Eugeniusza Piaseckiego w Poznaniu, Poznań.

Walesiak M. (1993), Statystyczna analiza wielowymiarowa $w$ badaniach marketingowych, Wydawnictwo Akademii Ekonomicznej we Wrocławiu, Wrocław.

Walesiak M., Gatnar E., (2009), Statystyczna analiza danych z wykorzystaniem programи R, Wydawnictwo Naukowe PWN, Warszawa. 
Warunki powstania $i$ działania oraz perspektywy rozwojowe polskich przedsiębiorstw powstatych w latach 2006-2010, (2012), Informacje i opracowania statystyczne, GUS, Warszawa.

Węgrzyn G. (2007a), Gospodarka oparta na wiedzy a rynek pracy, [w:] Piech K., Skrzypek E. (red), Wiedza w gospodarce, społeczeństwie i przedsiębiorstwach: pomiary, charakterystyka, zarzadzanie, Instytut Wiedzy i Innowacji, Warszawa, s. 241-248.

Węgrzyn G. (2007b), Innowacyjność polskiej gospodarki a sytuacja na rynku pracy, [w:] Wykorzystanie zasobów pracy we współczesnej gospodarce, red. D. Kopycińska, Uniwersytet Szczeciński, Szczecin, s. 130-139.

Wegrzyn G., (2008), Miejsca pracy $w$ sektorze ustugowym aktualne tendencje, [w:] Ustugi w Polsce - nauka, dydaktyka i praktyka wobec wyzwań przyszłości, red. A. Panasiuk, K. Rogoziński, „Zeszyty Naukowe Uniwersytetu Szczecińskiego”. nr 497, s. 93-99.

Wieczorkowska G., Wierzbiński J. (2007), Statystyka. Analiza badań społecznych, Wydawnictwo Naukowe SCHOLAR, Warszawa.

Wiśniewski F.(1965), Pojęcie i podział usług, „Ruch Prawniczy, Ekonomiczny i Socjologiczny" nr 2, s. 4.

Wlaźlak K. (2010), Rozwój regionalny jako zadanie administracji publicznej, Oficyna Wydawnicza Wolters Kluwers, Warszawa.

Wolfe M. (1955), The concept of economic sectors, „The Quarterly Journal of Economics" Vol. LXIX, s. 402-420.

Zienkowski L. (2001), Co to jest PKB? Jego rola $w$ analizach ekonomicznych i prognozowaniu, Dom Wydawniczy ELIPSA, Warszawa.

Zmiany strukturalne grup podmiotów gospodarki narodowej w 2006, 2007, 2008, 2010, Informacje i Opracowania Statystyczne GUS, Warszawa

Young F.W., de Leeuw J., Takane Y. (1976), Regression with qualitative variables: an alternating least squares method with optmal scaling features, „Psychometrika”, No. 41, s. 505-529.

\section{Strony internetowe}

www.ibs.org.pl

www.proinno-europe.eu

www.stat.gov.pl/gus/5840_4997_PLK_HTML.htm

www.macronext.pl

www.biec.org/main.php?display=produkty

http://dev3.uniaeuropejska.org/pmi-w-strefie-euro

www.ibngr.pl

http://forsal.pl/artykuly/673667,oecd_cli_dla_polski_wzrosl_w_listopadzie_2012_r.html www.ibs.org.pl

http://ibngr.pl/index.php/pl/lewe_menu/koniunktura_w_wojewodztwach

http://ecb.europa.eu

http://www.dausrissen.org/ 
ANEKSY 



\begin{tabular}{|c|c|c|c|c|c|c|c|c|c|c|c|c|c|c|c|c|}
\hline \multirow{2}{*}{\begin{tabular}{|l|}
3 \\
$\bar{E}$ \\
$\overline{0}$ \\
0 \\
00 \\
0 \\
0 \\
0 \\
\\
\\
\end{tabular}} & 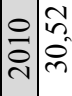 & $\begin{array}{l}0 \\
\text { an }\end{array}$ & $\hat{\Omega}$ & $\begin{array}{l}2 \\
n \\
n\end{array} \mid$ & $\begin{array}{l}2 \\
6 \\
6\end{array}$ & $\begin{array}{c}2 \\
\infty \\
\infty\end{array} \mid$ & $\underset{\infty}{\infty}$ & $\begin{array}{l}\hat{b} \\
\text { i }\end{array}$ & $\hat{m}$ & 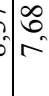 & $\begin{array}{l}1 \\
\delta \\
6\end{array}$ & $\vec{n}$ & $\begin{array}{l}n \\
i\end{array}$ & & \begin{tabular}{ll|l}
1 & 0 \\
0 & 0 \\
0 & 0 \\
0 & 0
\end{tabular} & \\
\hline & 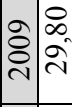 & $\begin{array}{l}\stackrel{2}{\circ} \\
\infty\end{array}$ & $\mid \begin{array}{l}2 \\
-\infty\end{array}$ & $\left|\begin{array}{l}n \\
f \\
6\end{array}\right|$ & તู & $\begin{array}{c}\Xi \\
\infty \\
\infty\end{array}$ & $\begin{array}{c}n \\
\infty \\
\infty\end{array}$ & $\begin{array}{l}\tilde{6} \\
i \\
-1\end{array}$ & $\begin{array}{l}\stackrel{0}{\infty} \\
\infty\end{array}$ & b. & $\begin{array}{l}n \\
\hat{n}\end{array}$ & $\nabla_{-}$ & $\overline{\mathrm{i}}$ & & م. & \\
\hline 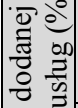 & 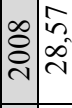 & $\hat{n}$ & 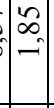 & $\left|\begin{array}{l}n \\
f \\
6\end{array}\right|$ & $\stackrel{\text { సે }}{\infty}$ & $\left|\begin{array}{c}\infty \\
+ \\
\sigma \\
\vdots\end{array}\right|$ & $\widehat{\curvearrowright}$ & $\begin{array}{c}f \\
\stackrel{q}{i} \\
i\end{array}$ & $\begin{array}{l}\vec{m} \\
\infty\end{array}$ & $\delta_{0}^{\circ}$ & $\begin{array}{l}\infty \\
\infty \\
n\end{array}$ & & iे & & ch & \\
\hline 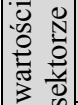 & 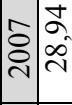 & $\begin{array}{l}\curvearrowright \\
\infty\end{array}$ & 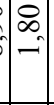 & 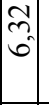 & 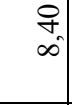 & $\left|\begin{array}{l}\infty \\
n \\
\alpha\end{array}\right|$ & $\stackrel{\alpha}{\Omega}$ & $\begin{array}{l}\text { त̂ } \\
\text { i }\end{array}$ & $\overline{\infty^{\circ}}$ & $=0$ & $\begin{array}{l}n \\
n\end{array}$ & & $\begin{array}{c}5 \\
m\end{array}$ & & 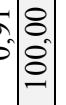 & \\
\hline $\begin{array}{l}3 \\
:=0 \\
\frac{0}{0} \\
0 \\
\infty\end{array}$ & $\begin{array}{ll} & 0 \\
0 & 0 \\
0 & \infty \\
\text { N } & \\
\end{array}$ & $\frac{a}{a}$ & 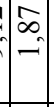 & & ก̂? & $\frac{\infty}{0}$ & $\begin{array}{l}+ \\
\infty \\
\infty\end{array}$ & $\begin{array}{l}n \\
\mathrm{i}\end{array}$ & $\underset{\infty}{\vec{\nabla}}$ & $5 \stackrel{2}{2}$ & $\begin{array}{l}0 \\
\infty \\
n\end{array}$ & & $\begin{array}{c}m \\
m \\
m\end{array}$ & & 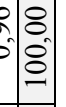 & \\
\hline 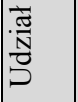 & 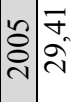 & $\begin{array}{l}\hat{b} \\
\infty\end{array}$ & $\bar{\sigma}$ & $\mid$\begin{tabular}{|} 
\\
6 \\
6
\end{tabular} & $\begin{array}{l}2 \\
0 \\
0\end{array}$ & $\mid \begin{array}{l}0 \\
0 \\
0\end{array}$ & $\begin{array}{l}0 \\
\infty \\
\sim \\
\sim\end{array}$ & $\hat{\sigma}$ & ले & $=0$ & $\begin{array}{l}0 \\
n \\
n \\
n\end{array}$ & & 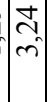 & $\stackrel{\circ}{\circ}$ & م. & \\
\hline \multirow{6}{*}{ 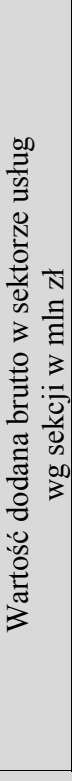 } & 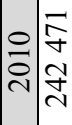 & $\begin{array}{l}\stackrel{n}{n} \\
\stackrel{2}{r}\end{array}$ & $\begin{array}{l}n \\
0 \\
n \\
n \\
n\end{array}$ & $\left|\begin{array}{l}\infty \\
2 \\
2 \\
n \\
\gamma\end{array}\right|$ & $\begin{array}{l}\bar{\nabla} \\
\hat{n}\end{array}$ & $\begin{array}{l}\hat{\tilde{D}} \\
\infty \\
\hat{ర}\end{array}$ & $\begin{array}{l}\mathcal{I} \\
\mathfrak{Z}\end{array}$ & $\begin{array}{l}\stackrel{0}{n} \\
\stackrel{\sim}{\sim}\end{array}$ & 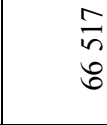 & $=$ & \begin{tabular}{l}
$m$ \\
$\infty$ \\
\multirow{\gamma}{\gamma}{}
\end{tabular} & $\begin{array}{l}\mathfrak{n} \\
f \\
0 \\
0\end{array}$ & $\begin{array}{l}\tilde{a} \\
\infty \\
\vec{\sim}\end{array}$ & $\begin{array}{l}\circ \\
\stackrel{+}{\sigma}\end{array}$ & 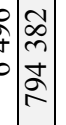 & $\frac{\vec{D}}{\Delta}$ \\
\hline & 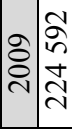 & $\begin{array}{l}8 \\
8 \\
6\end{array}$ & 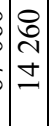 & $\left|\begin{array}{l}\infty \\
\infty \\
n \\
\infty \\
+\end{array}\right|$ & $\begin{array}{l}2 \\
\infty \\
0 \\
0\end{array}$ & $\begin{array}{l}q \\
\mathrm{f} \\
\hat{\sigma}\end{array}$ & $\begin{array}{l}\mathfrak{d} \\
\mathfrak{d} \\
\dot{b}\end{array}$ & 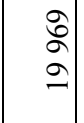 & \begin{tabular}{l}
$\stackrel{\infty}{\sim}$ \\
\multirow{2}{*}{}
\end{tabular} & $\begin{array}{l}0 \\
0 \\
0 \\
0\end{array}$ & $\begin{array}{l}\mathfrak{g} \\
\infty \\
\forall \\
\forall\end{array}$ & $\begin{array}{l}0 \\
8 \\
0 \\
0\end{array}$ & $\begin{array}{l}\text { ลิ } \\
\alpha \\
\bar{N}\end{array}$ & $\underset{\hat{\sigma}}{\hat{\sigma}}$ & 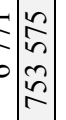 & 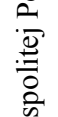 \\
\hline & 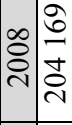 & 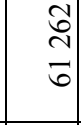 & $\begin{array}{l}2 \\
\overrightarrow{2} \\
-2\end{array}$ & $\mid$\begin{tabular}{c}
$\vec{N}$ \\
\hdashline \\
$\dot{f}$
\end{tabular} & $\begin{array}{l}\infty \\
\vec{\lambda} \\
\dot{n}\end{array}$ & $\begin{array}{l}\infty \\
2 \\
6 \\
6\end{array}$ & $\begin{array}{l}0 \\
5 \\
\vdots \\
i\end{array}$ & $\begin{array}{l}0 \\
\stackrel{2}{n} \\
=\end{array}$ & \begin{tabular}{l}
\multirow{2}{5}{} \\
ñ \\
ñ
\end{tabular} & $\hat{n}$ & $\begin{array}{l}\stackrel{\gamma}{J} \\
\mathcal{y} \\
\mathcal{f}\end{array}$ & $\begin{array}{l}0 \\
\infty \\
a \\
a\end{array}$ & 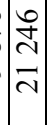 & $\underset{b}{\stackrel{J}{7}}$ & 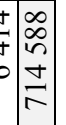 & $\begin{array}{l}\widehat{N} \\
\mathbb{D} \\
\mathbb{N}\end{array}$ \\
\hline & 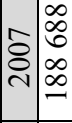 & $\begin{array}{c}\overline{6} \\
\infty \\
\infty \\
n\end{array}$ & $\stackrel{n}{\therefore}$ & $\begin{array}{l}\infty \\
\infty \\
\\
\\
\end{array}$ & $\begin{array}{l}\infty \\
\infty \\
\dot{N} \\
n\end{array}$ & 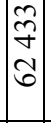 & $\begin{array}{l}\hat{\sigma} \\
\hat{0} \\
\hat{n}\end{array}$ & $\begin{array}{l}\stackrel{ \pm}{ \pm} \\
\stackrel{\sim}{=}\end{array}$ & 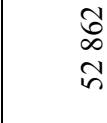 & $\begin{array}{l}0 \\
\vdots \\
\infty \\
a \\
a\end{array}$ & 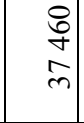 & $\begin{array}{c}\stackrel{ }{r} \\
\stackrel{r}{r}\end{array}$ & 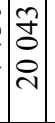 & & $\hat{n}$ & 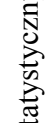 \\
\hline & 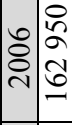 & $\begin{array}{l}\hat{\overbrace{}} \\
\hat{0} \\
\hat{n}\end{array}$ & $\mid \begin{array}{l}0 \\
2 \\
\infty \\
0 \\
0\end{array}$ & $\mid \begin{array}{l}0 \\
0 \\
m \\
\infty \\
\infty \\
m\end{array}$ & \begin{tabular}{l}
8 \\
$\stackrel{0}{n}$ \\
$\sim$ \\
\multirow{7}{*}{}
\end{tabular} & $\begin{array}{l}\hat{\sigma} \\
\text { N } \\
\hat{n}\end{array}$ & 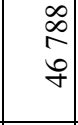 & $\begin{array}{l}a \\
\\
\end{array}$ & $\begin{array}{l}+ \\
\circ \\
\infty \\
+\end{array}$ & 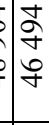 & $\begin{array}{l}\sqrt{6} \\
0 \\
\dot{m} \\
m\end{array}$ & $\begin{array}{c}\infty \\
\stackrel{\sim}{\forall} \\
\sigma\end{array}$ & $\left|\begin{array}{l}0 \\
0 \\
2 \\
2\end{array}\right|$ & $\begin{array}{l}\overline{0} \\
i n \\
n\end{array}$ & 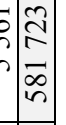 & స్ \\
\hline & 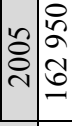 & \begin{tabular}{l}
$\stackrel{2}{2}$ \\
\multirow{7}{7}{}
\end{tabular} & $\mid \begin{array}{l}0 \\
0 \\
2 \\
0\end{array}$ & $\begin{array}{c}m \\
\hat{n} \\
\tilde{n} \\
\end{array}$ & $\begin{array}{c}\mathbb{8} \\
-1 \\
\infty \\
m\end{array}$ & $\begin{array}{l}\hat{2} \\
i n \\
i n\end{array}$ & 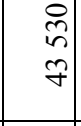 & $\begin{array}{l}m \\
2 \\
0\end{array}$ & $\begin{array}{l}\overrightarrow{7} \\
\text { † } \\
+\end{array}$ & $=\left[\begin{array}{l}\infty \\
\infty \\
\infty \\
f \\
\forall\end{array}\right.$ & 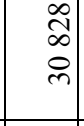 & $\frac{\mathfrak{g}}{-1}$ & $\begin{array}{l}-1 \\
0 \\
- \\
-1\end{array}$ & $\begin{array}{l}\text { m } \\
\text { ñ }\end{array}$ & 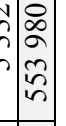 & 就 \\
\hline 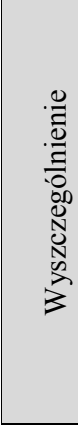 & 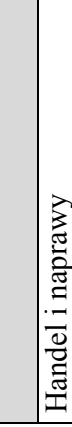 & 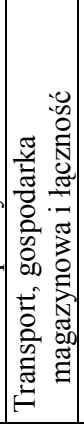 & 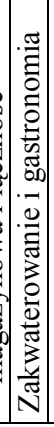 & 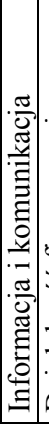 & 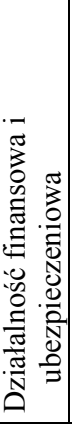 & 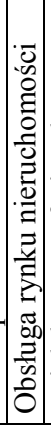 & 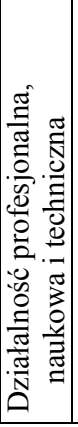 & 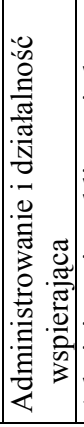 & 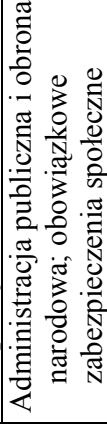 & 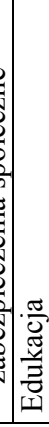 & 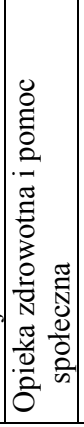 & 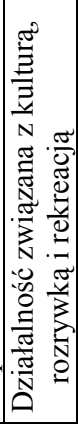 & 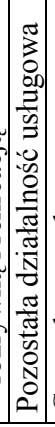 & 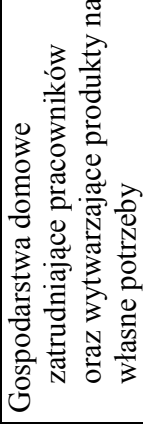 & 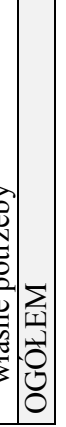 & 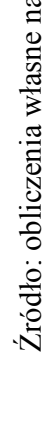 \\
\hline
\end{tabular}




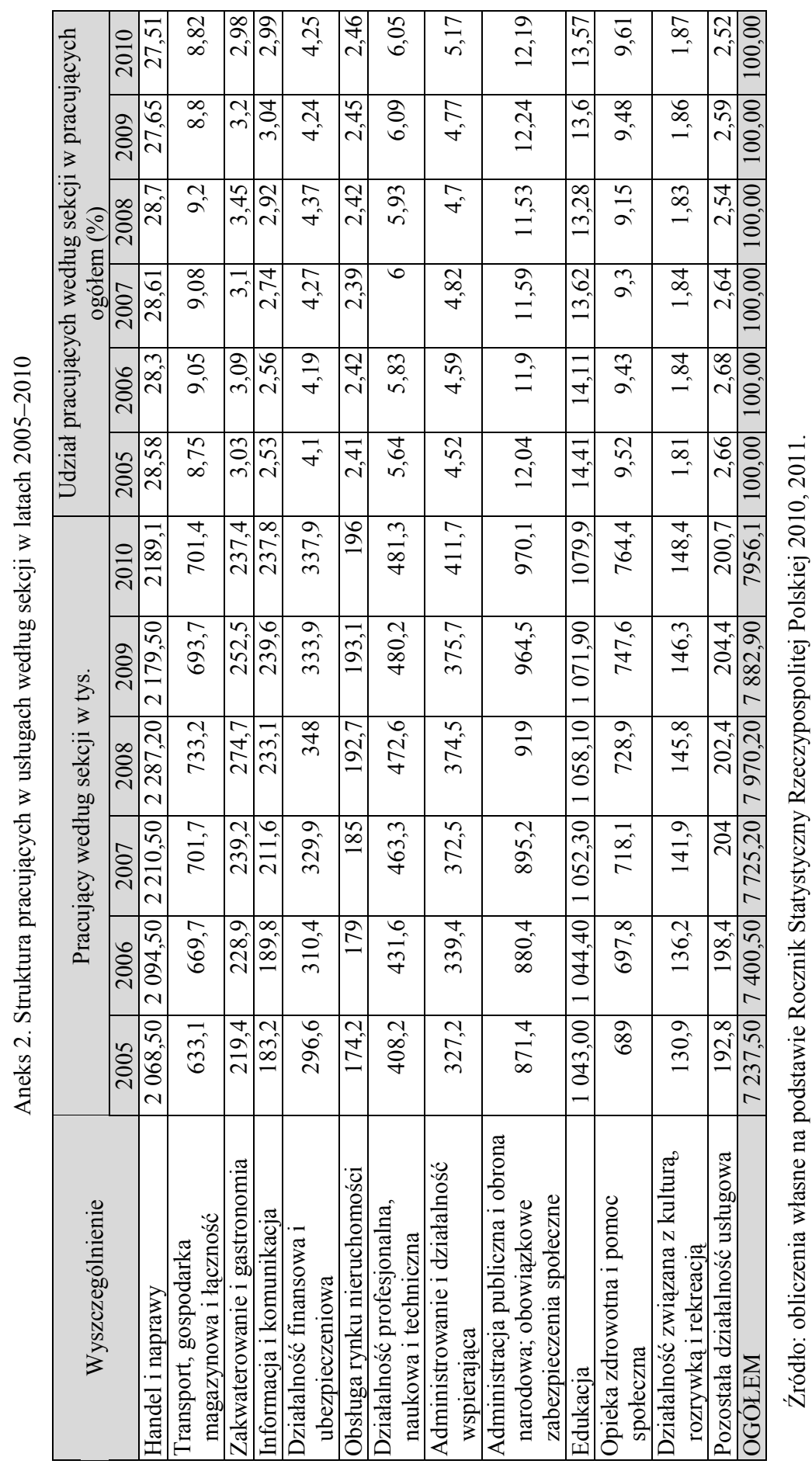




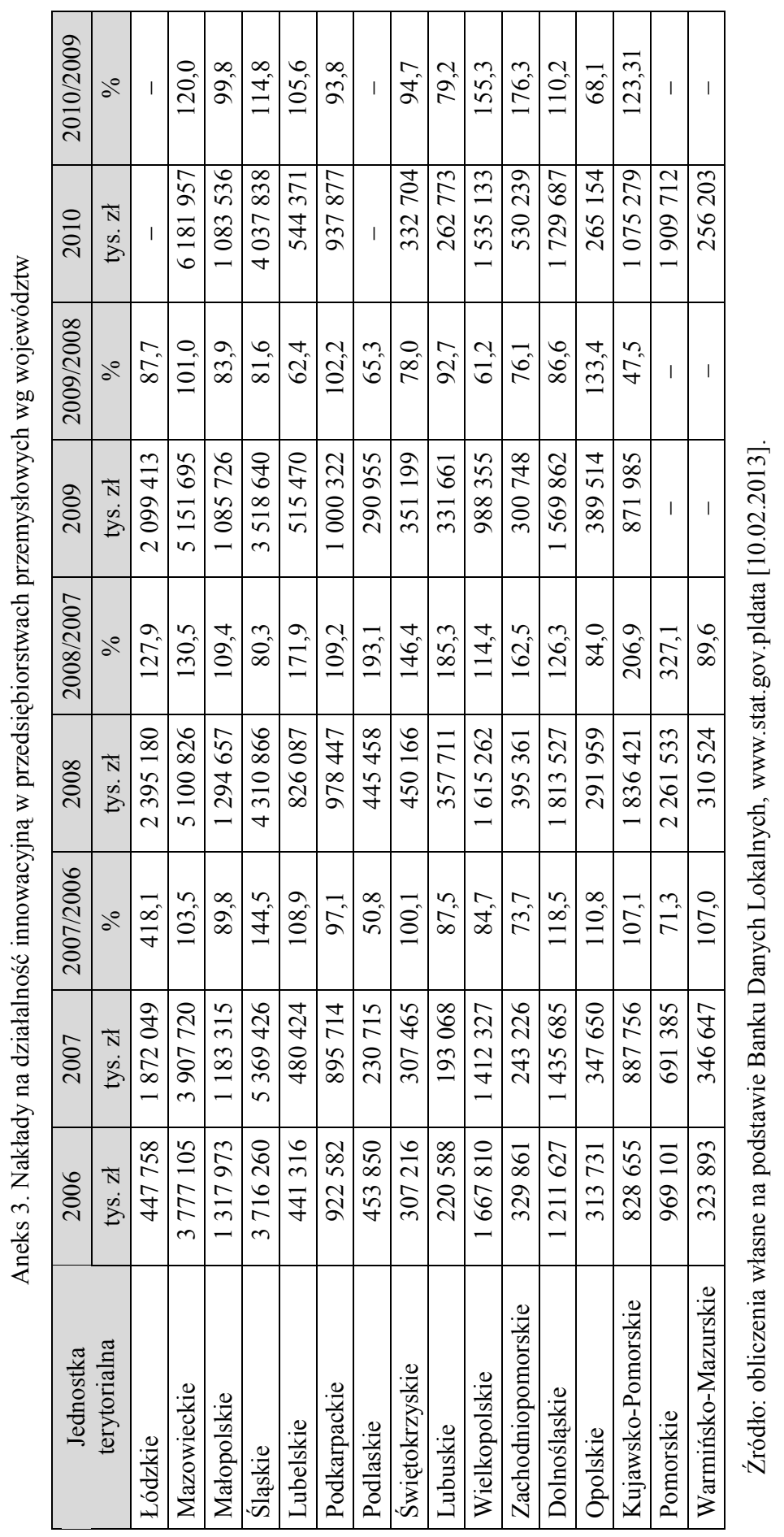




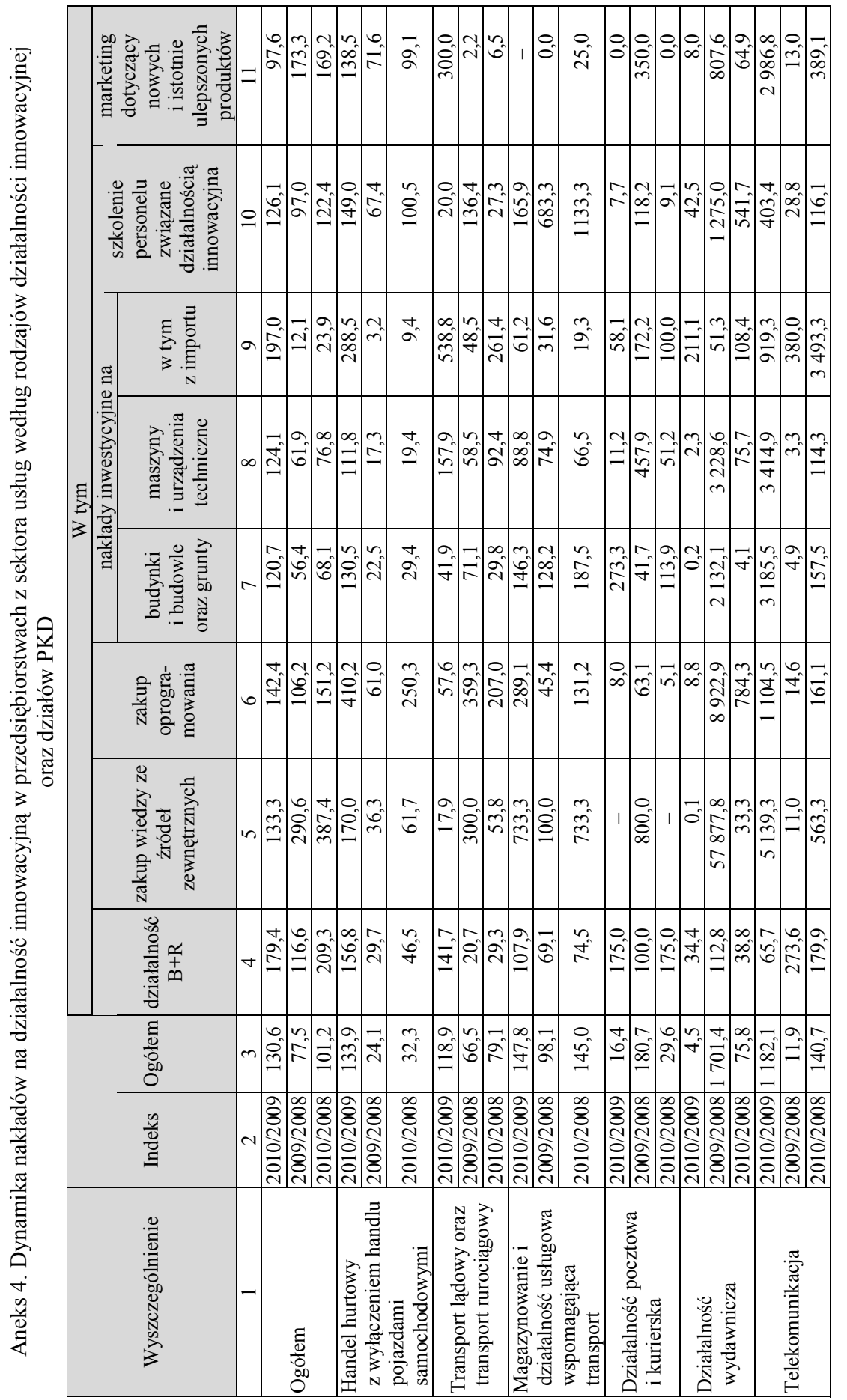




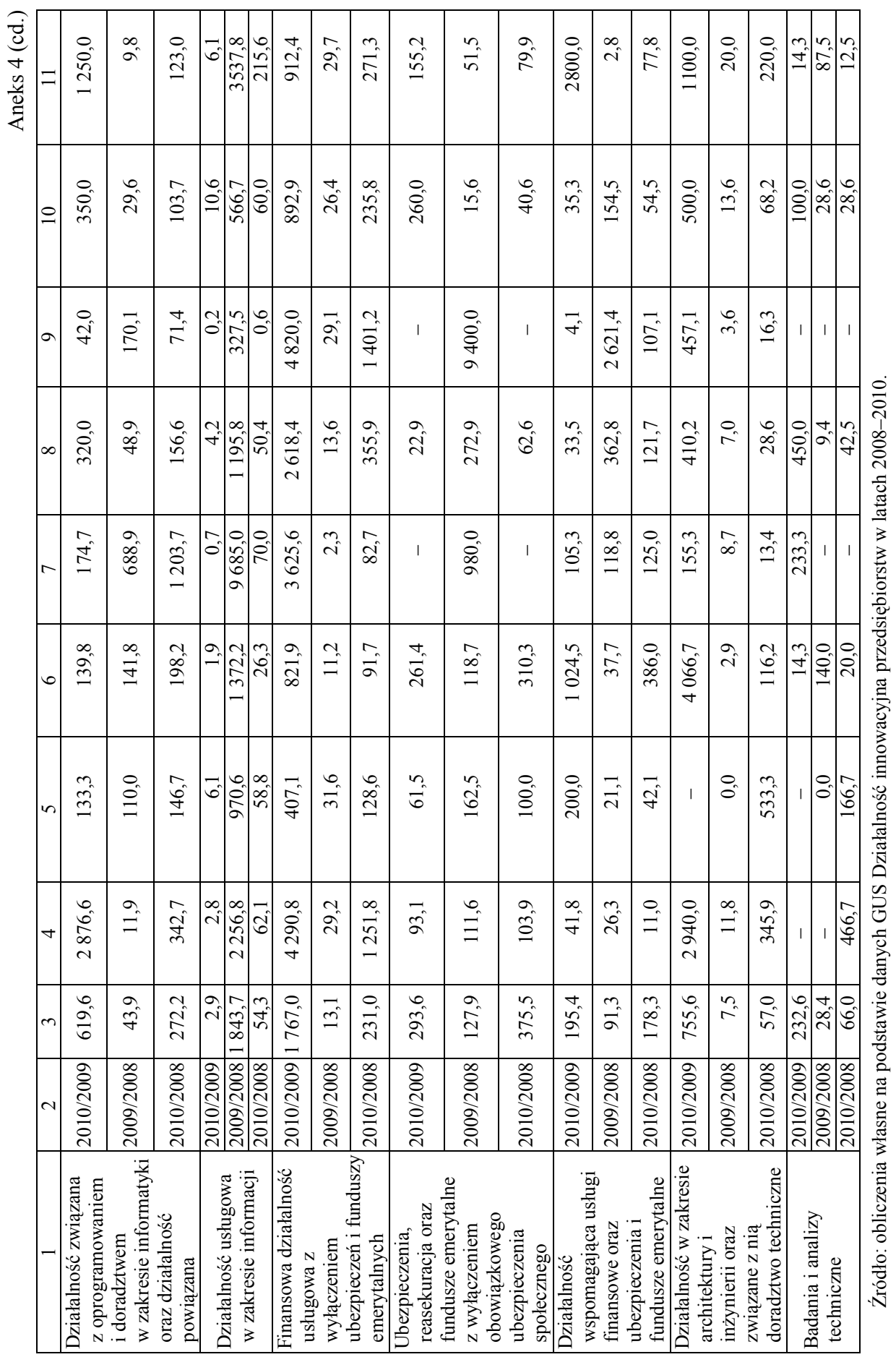




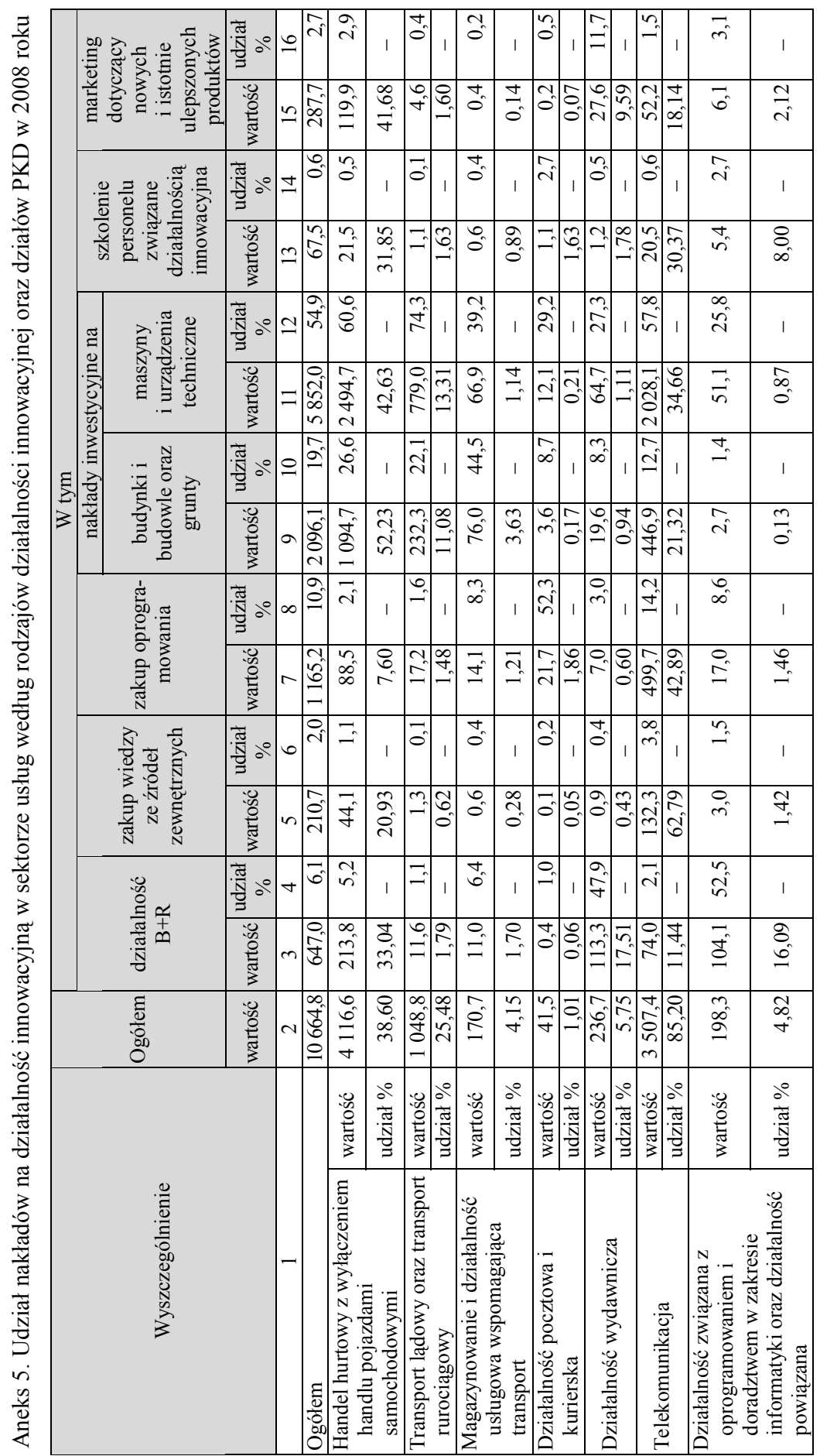




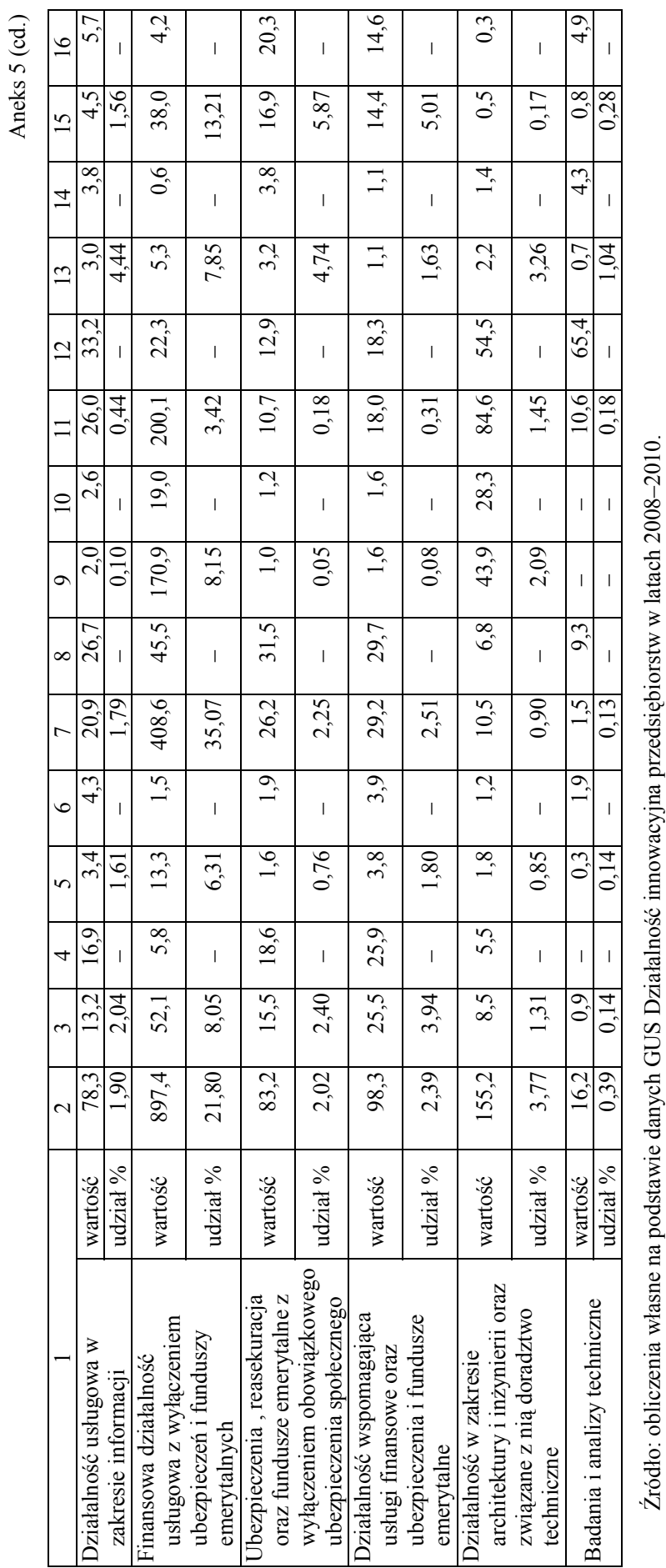




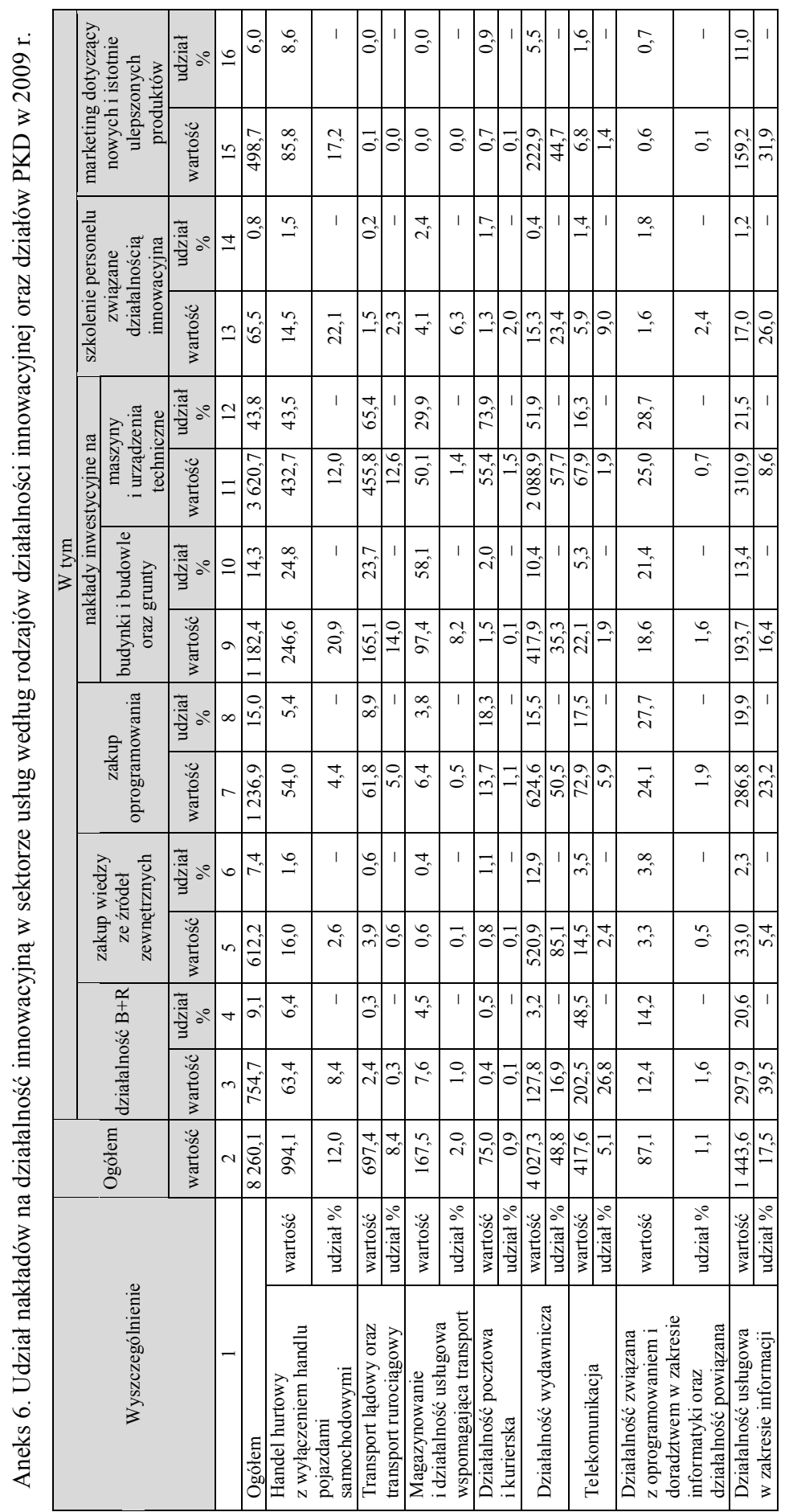




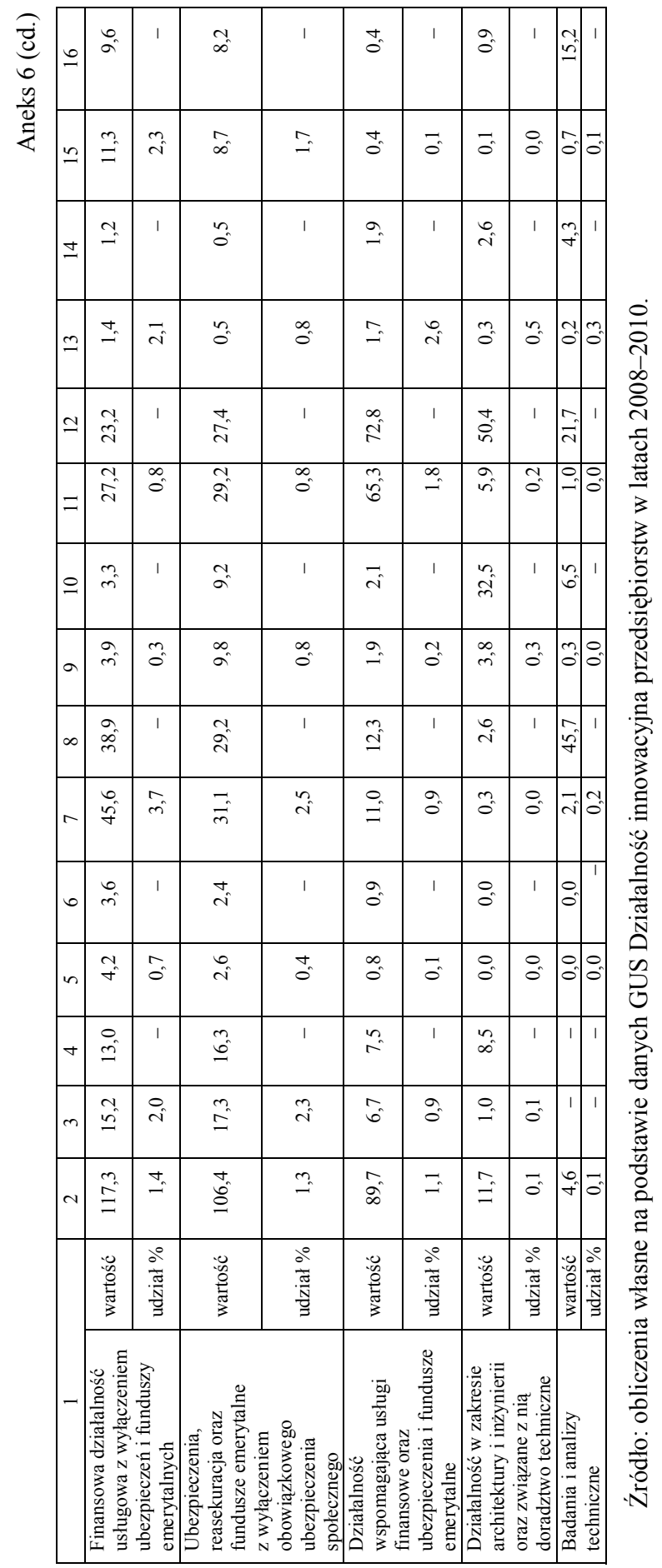




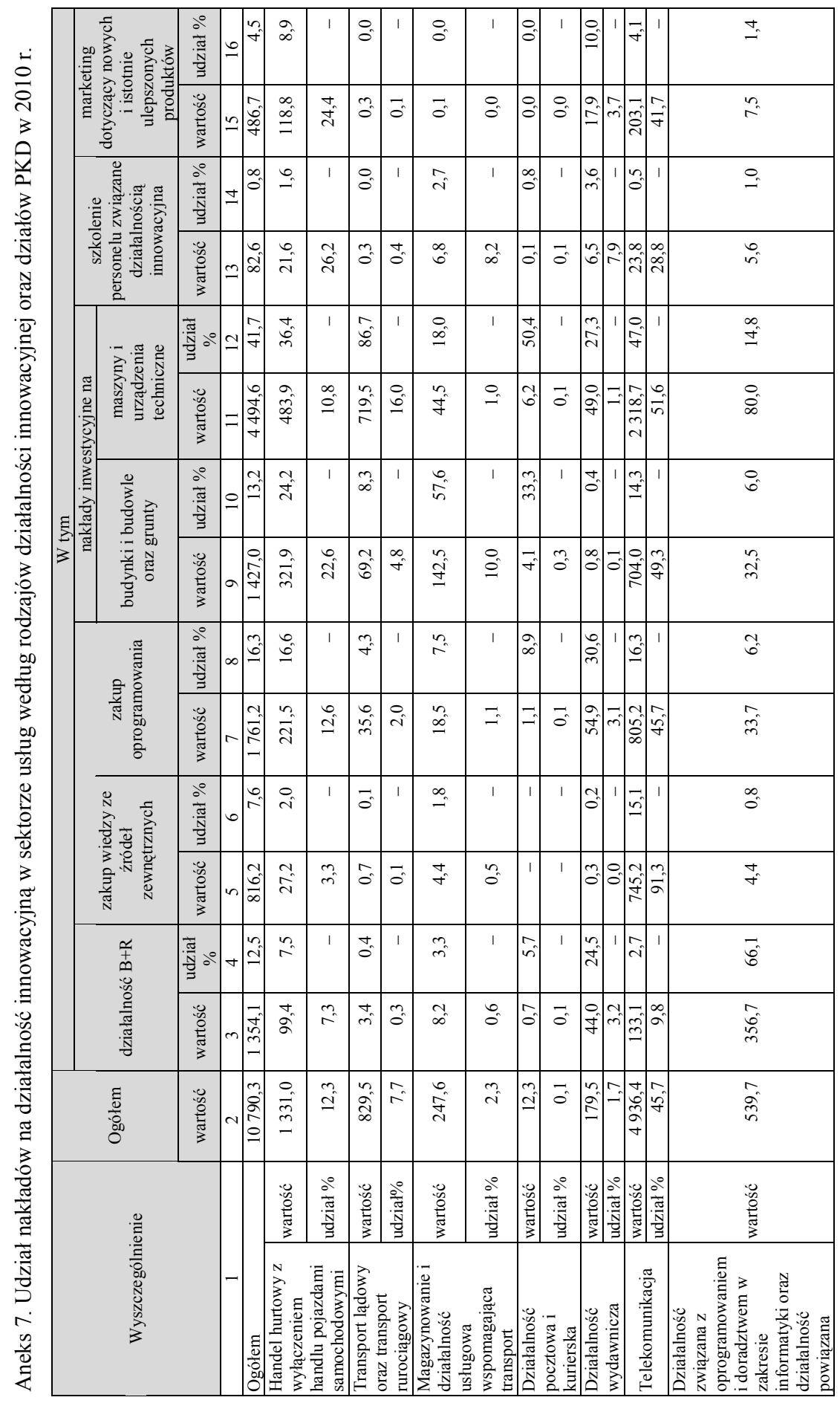




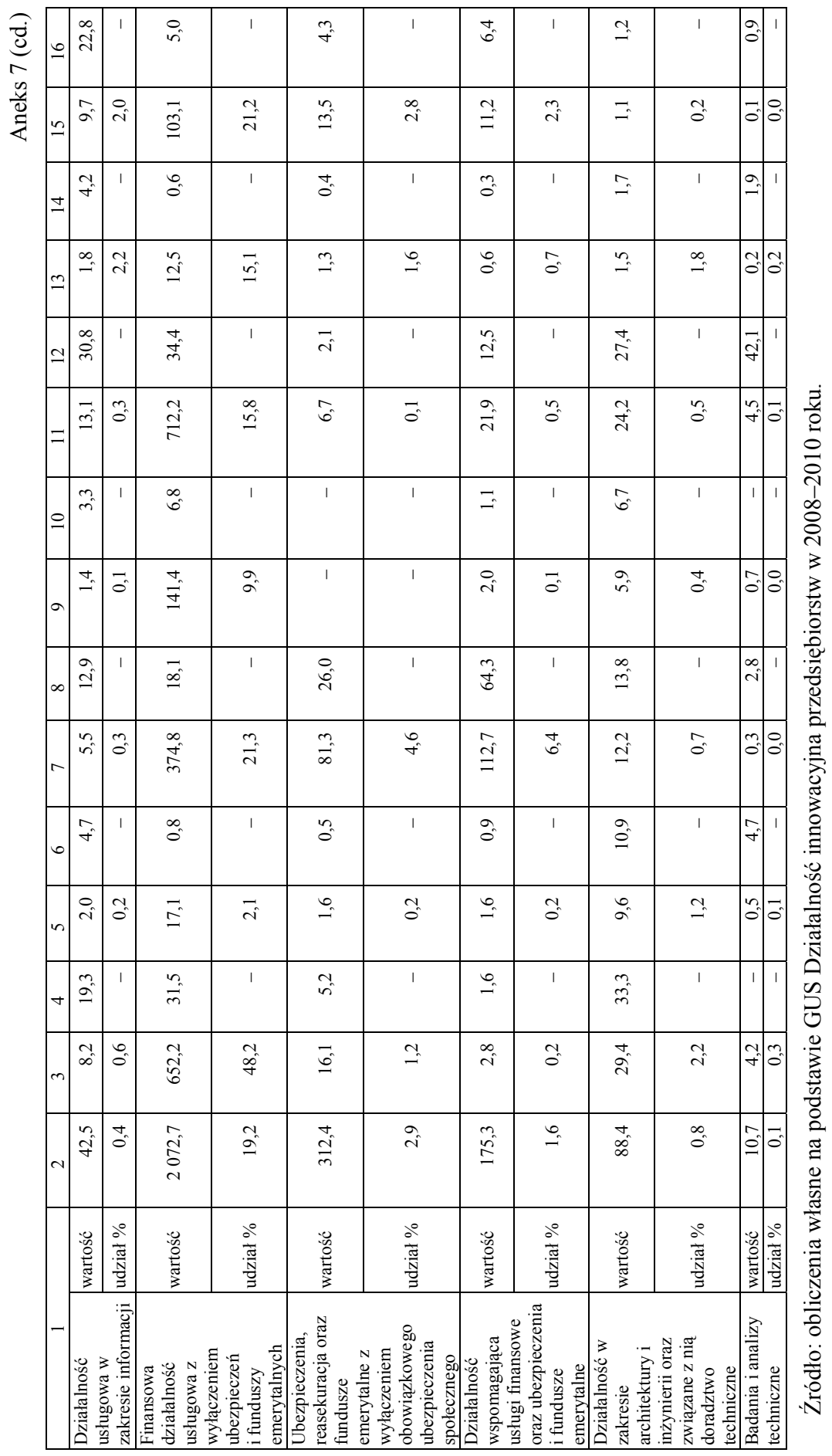


nr str. 1

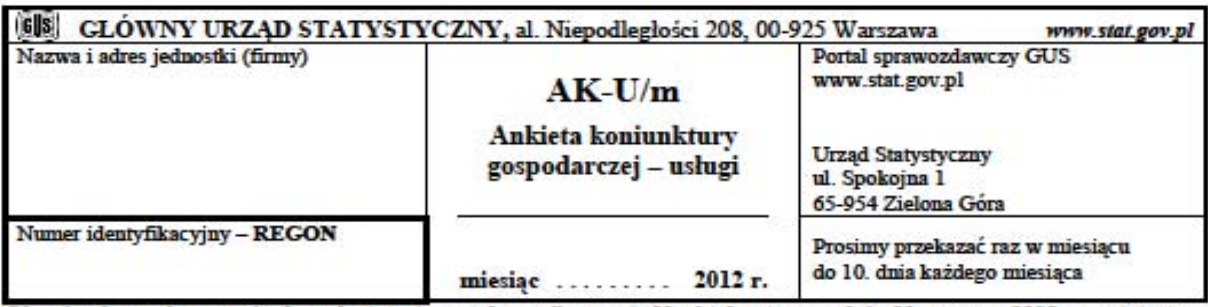

Obowiązek przelazywania danych statystycznych wynika $z$ art. 30 pkt 3 ustawy $z$ dnia 29 czerwca 1995 r. o statystyce publiczmej (Dz. U. Nr 88, poz. 439, z pózin. zm.) oraz rozporządzenia Rady Ministróx z dnia 22 lipca 2011 r. w spravie programu badań statystyczmych statystyki publiczej na rok 2012 (Dz. U. Nr 173, poz. 1030).

\section{Lل}

\section{Djiekanjemy za terminowe wypelnienie ankieny i gwarannujemy zachowanie tajemnicy stanstyeznej Odpowiedzi powinny być udzielane z wyłączeniem wpływu czynnila sezonowego, czyli z pominięciem zmian charakterystycznych dla danego okresu rolu.}

I. Ocena sytuacji gospodarczej

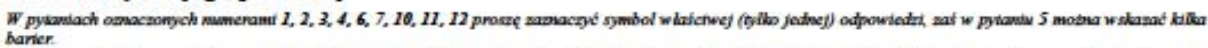

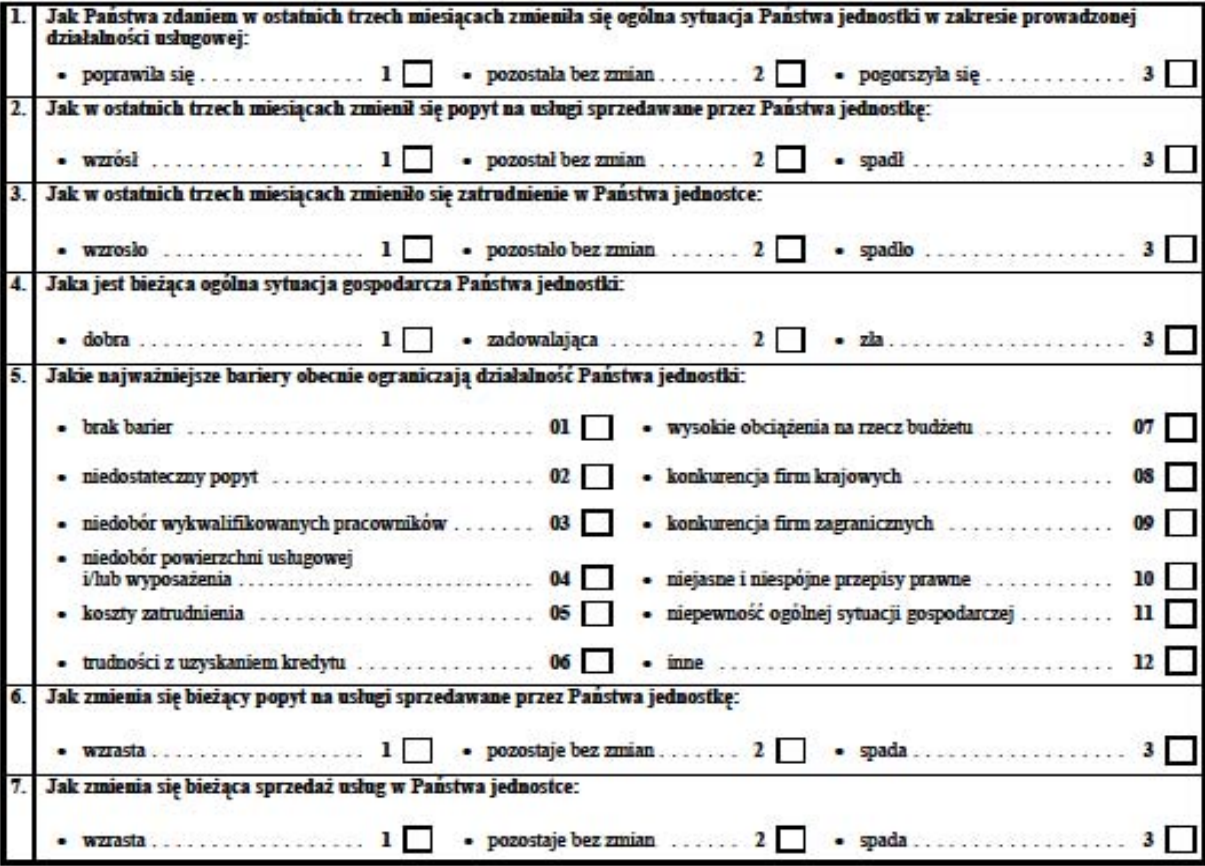


I. Ocena sytuacji gospodarczej (dokończenie)

\begin{tabular}{|c|c|}
\hline 8. & $\begin{array}{l}\text { Jali procent posiadanych pehnych mocy produkcyjuych (pracownicy, wyposaienie, środli transportu, } \\
\text { powierzchnia itp.) Państwa jednostli jest obecnie wykorzystywany: }\end{array}$ \\
\hline 9. & De obecnie wynosi zagwarantowany olrres dziabnia Państwa jednostli ( $w$ miesiaccach): \\
\hline 10. & 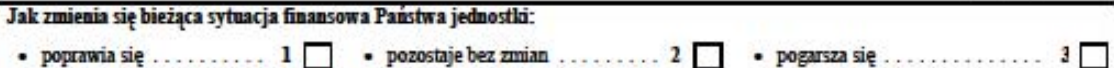 \\
\hline III & 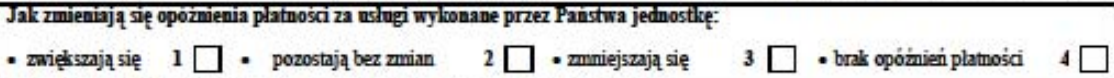 \\
\hline 12. & 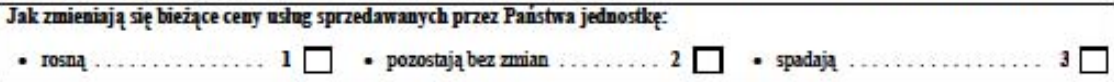 \\
\hline
\end{tabular}

\section{Prognoza sytuacji gospodarczej}

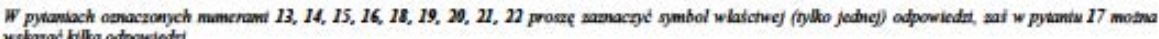
wsiknad killa odpowiedti.

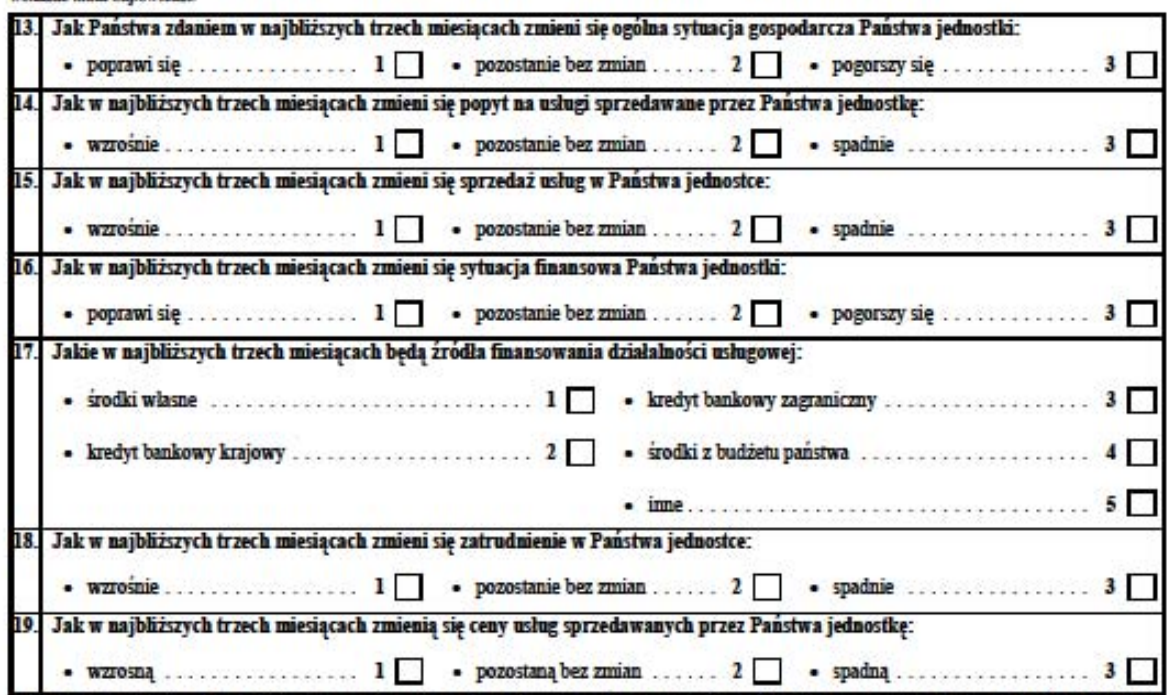

20. Jak w najbliżsych miesiącach zmienią się nalłady imwestycyjne (wyposażenie, środlia transportu, budynla itp.) w Pansstwa jednostce:

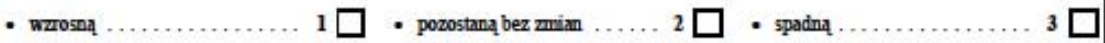

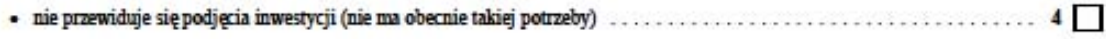

- nie przewiduje się podjęcia inwestycji (brak środków)

21. Przy zgloszonym biezącym popycie i przewidywanych na najblizisze miesiace jego zmianach alctualne moce produlacyjne (pracownicy, wyposażenie, środli transportu, powierzchnia itp.) Państwa przedsęebiorstwa sq:

- zbyt duje ............. $1 \square$. wystarczajace........2 $\square$ • zbyt male

22. Jési wzróslby popyt na ushugi świadczone przez Paístwa jednostlke, czy przy posiadanych zasobach mogą Paístwo rozzzerzyć drialalność?

- NIE $\square$ - TAK $\square$ jeśli TAK, to o ile ............................................... $\square \square \square, \square \%$

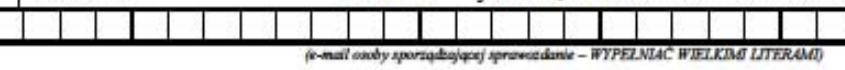



Summary

\section{STATISTICAL ASSESSMENT OF THE IMPORTANCE OF THE SERVICE SECTOR FOR THE POLISH ECONOMY}

The service sector is currently the most important sector of the European economy. In the process of the social and economic development of countries, the importance of the service sector increases both at the level of employment and the gross added value.

The thesis presents changes occurring in the service sector in the years 1994-2011 against the background of other sectors. The research focused on determining the role of the service sector by analysing its influence on the process of social and economic development. Attention was also paid to determinants of innovative activity in the service sector and the influence of the economic situation on this sector.

The aim of the thesis was to present the spatial differentiation of the service level in Poland and to define the directions of changes occurring in this sector.

The thesis presents both theoretical and empirical aspects of this issue. In the empirical part, analyses were conducted at international, national and regional levels.

The thesis consists of five chapters. Chapter One defines the notion of services, its evolution and process of shaping the service sector in accordance with the three-sector division of the economy. Characteristic features of services, classification and functions fulfilled by this sector in the economy were presented. On the basis of various economic theories, developmental tendencies in the service sector were identified.

The complexity of the developmental process and the diversity of services, which is influenced by a lot of variables, make it necessary to select the appropriate statistical methods to perform an objective assessment of the service market in Poland. To achieve this goal, various statistical methods were used in Chapter Two, including: measures of distribution, differentiation, dynamics, factor analysis, multidimensional scaling, Perkal's and Helwig's measure of development and spatial models.

Chapter Three presents the process of the service sector development in Poland, including other sectors of the economy and against the background of the European Union countries. In this chapter, changes occurring in the number 
of people employed, the gross added value and the number of economic entities according to the sector were analysed. Also, a comparative analysis of the degree of differentiation in the development of the service sector on the basis of the proposed indicators according to provinces take into account individual service sections.

Considerations in Chapter Four focus on innovative activities in service entities. This chapter analyses the innovativeness as a determinant for the development of the service sector and an element of the competitive edge. An assessment was performed and directions for the development of innovativeness in the service sector were identified.

In Chapter Five, a diagnosis was provided on the basis of the current research results and an attempt was made to forecast the economic situation in the Polish economy as a whole and in the service sector according to provinces.

The research conducted and the results obtained on their basis made it possible to conclude that the economy sector in contemporary economies and, in particular, in highly developed countries occupies a dominant position, which is confirmed by its predominant share in the generation of the added value and employment levels. 